$$
\text { Universidade de São Paulo }
$$

Faculdade de Filosofia, Letras e Ciências Humanas

Departamento de Antropologia

Programa de Pós-Graduação em Antropologia Social

\title{
Modos ameríndios de conhecer as florestas: produção de relações e percepções \\ (versão corrigida)
}

\author{
Priscila Matta
}




\section{Modos ameríndios de conhecer as florestas:}

\section{produção de relações e percepções}

(versão corrigida)

\section{Priscila Matta}

Tese apresentada ao Programa de Pós-Graduação em Antropologia Social da Faculdade de Filosofia, Letras e Ciências Humanas da Universidade de São Paulo, para a obtenção de título de Doutor em Antropologia Social.

Orientadora: $\operatorname{Prof}^{\mathrm{a}}$. Dr ${ }^{\mathrm{a}}$. Dominique Tilkin Gallois

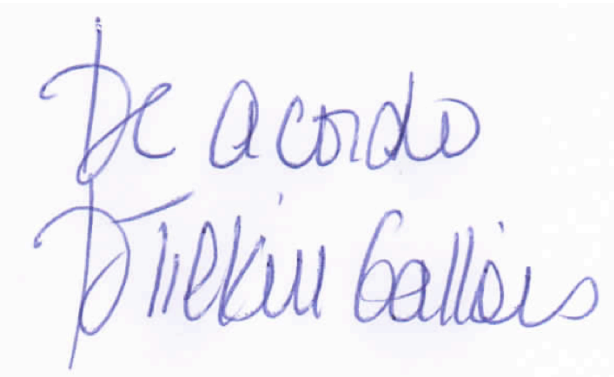

São Paulo 
Para GISELA MATTA (in memoriam) por existir

Para VITO M. VERNA por sua força e alegria de viver

Para ELISABETH H. MATTA pelos cuidados e firmeza 


\title{
Resumo
}

Esta tese tem como foco modos ameríndios de conhecer e circular nas florestas, importante domínio cosmológico e de produção da vida. Mais especificamente, a tese está centrada nos saberes e nas formas de relações estabelecidas a partir de elementos vegetais, que envolvem múltiplas interações entre humanos e não humanos. Este trabalho está fundamentado, em grande parte, em levantamentos bibliográficos, mas também em material de campo levantado entre os Araweté, povo tupi-guarani habitante da região do Médio Xingu - Pará.

Palavras-chave: cosmologias ameríndias, modos de saber, domínios vegetais, florestas, Araweté.

\section{Title}

Amerindian Ways of Knowing the Forest: the Production of Relations and Perceptions

\begin{abstract}
This thesis focuses on Amerindian ways of knowing and moving in the forest, an important cosmological and life production domain. More specifically, the thesis is centered on the knowledge and relations established with the vegetation, which involve multiple interactions between humans and non-humans. The work is largely based on bibliographic survey but also on fieldwork material gathered amongst the Araweté, Tupi-Guarani people that inhabitant the Middle Xingu region of Pará.
\end{abstract}

Keywords: Amerindian cosmologies, ways of knowing, vegetation domains, forests, Araweté. 


\section{AGRADECIMENTOS}

Agradeço a todos aqueles e às instituições que possibilitaram a elaboração desta tese.

Agradeço a Dominique T. Gallois, que acreditou e topou o desafio de me orientar, por seus fundamentais e valiosos ensinamentos e pelo exemplo de dedicação e comprometimento.

Agradeço aos Araweté, especialmente aos moradores das aldeias Ta'akati, Djuruanti e Aradjyti e à Hawutire, Tatuawi e Kuniawi du (Kupire), que me receberam, acolheram e foram essenciais nesse processo de aprendizados e descobertas.

Agradeço sempre a Aracy Lopes da Silva (in memoriam) pelos incentivos aos primeiros passos na "aventura antropológica" e, mais do que isso, pelo acolhimento e carinho.

Agradeço a Beatriz Perrone-Moisés, Marta Rosa Amoroso, Regina A. Polo Müller e Uirá Felippe Garcia pelas valiosas contribuições, comentários e sugestões que fizeram na defesa desta tese.

Agradeço aos próximos pelo carinho, dedicação, incentivo, colaboração e compreensão e, entre eles, eu não poderia deixar de mencionar, em categorias, momentos e proximidades diferentes, Bia Matta, Ana Clara, Lia, Thomas, tia Jane (in memoriam), Soninha ou 'Sonha' Lorenz, Fabio N. Ribeiro, Mari e Rafa, Ana M. T. Yano, especialmente, Adriana Queiroz Testa, Joana Cabral de Oliveira, Cássio N. I. de Sousa, Soraia C. Saura, Sergio Talocchi, Simone Conte, Sabrina Sanches, Fernandas Ferraz e Saturni e Janice Casara.

Por fim, agradeço à FAPESP, que através da Pesquisa Temática "Redes ameríndias: geração e transformação nas terras baixas sul-americanas", desenvolvida no âmbito do NHII - USP / Núcleo de História Indígena e do Indigenismo, e ao PPGAS - USP / Programa de Pós-Graduação em Antropologia Social pelo auxílio a viagens para a realização de pesquisas de campo. 


\section{SUMÁRIO}

Introdução

Nota sobre a pesquisa e a experiência com os Araweté ...........................................06

Do concreto ao compartilhado a partir de bases etnográficas ...................................09

Capítulo I - Sobre descontinuidades nas composições das florestas ....................13

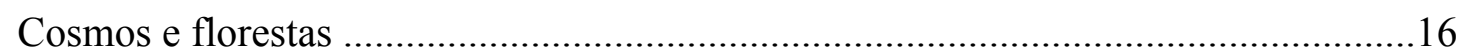

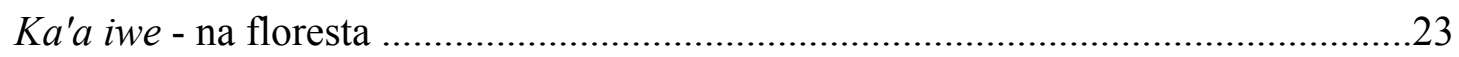

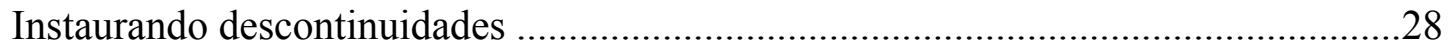

Nem tudo é plantado: posições identificadas a partir dos vegetais ............................31

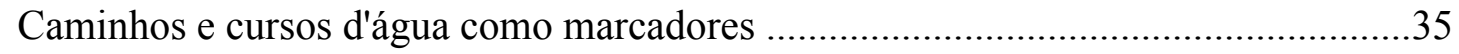

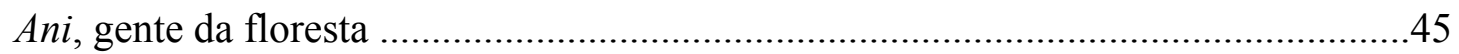

Quando florestas viram "acampamentos-aldeias"..................................................50

Capítulo II - Vegetais como índices de relações ................................................55

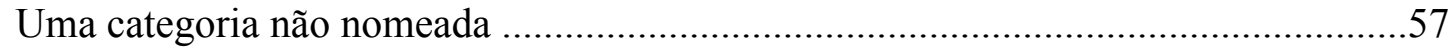

Princípio da similaridade para categorizar os vegetais .............................................62

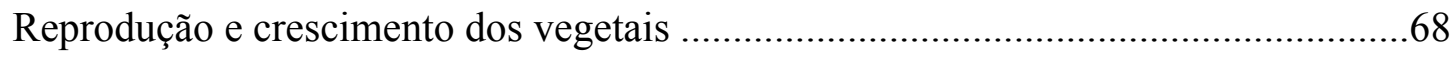

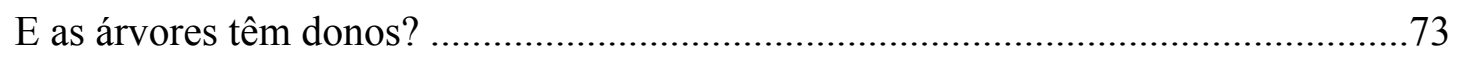

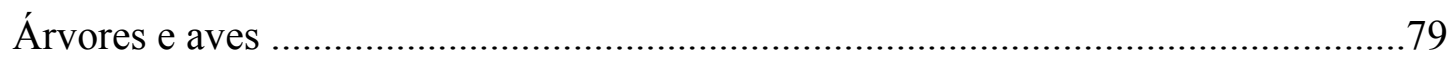

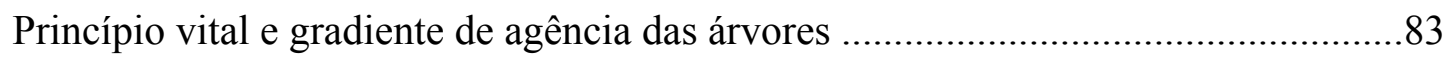

Frutos comidos por alguém: aromas como fator de atração ......................................87

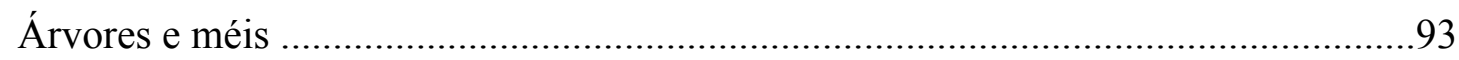

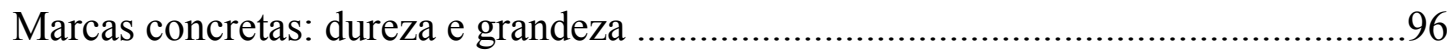

Transformações das árvores pelos usos ................................................................99

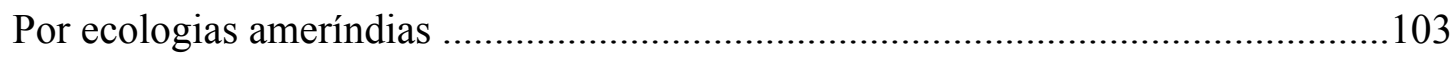


Capítulo III - Dimensões da socialidade: produção de relações e percepções ...107

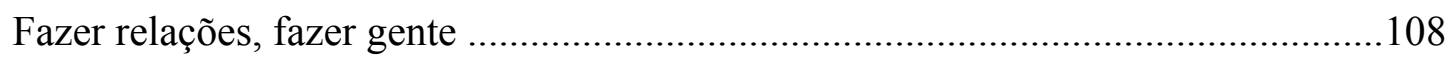

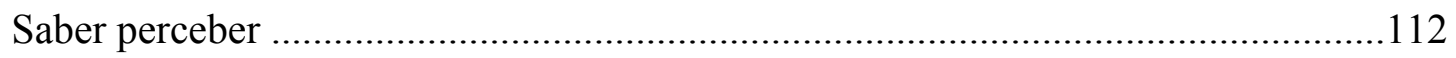

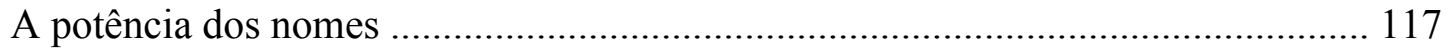

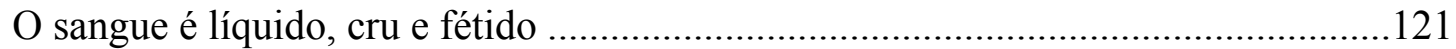

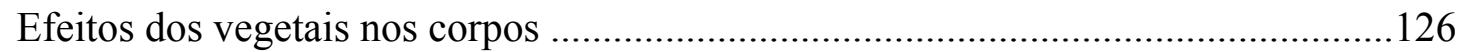

Carne e farinha: formas de comer e fazer para ser e estar ......................................135

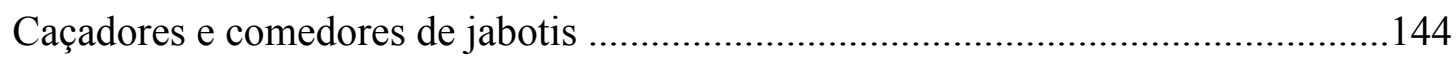

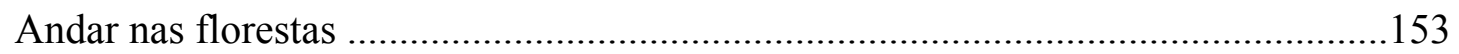

Capítulo IV - Modos ameríndios de constituir saberes ....................................156

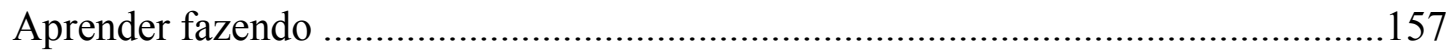

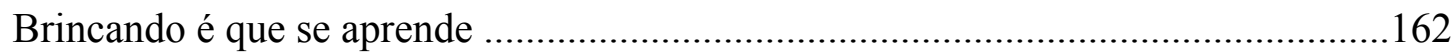

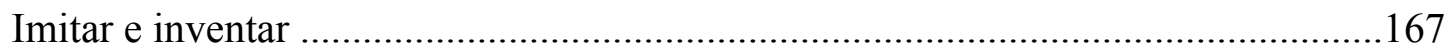

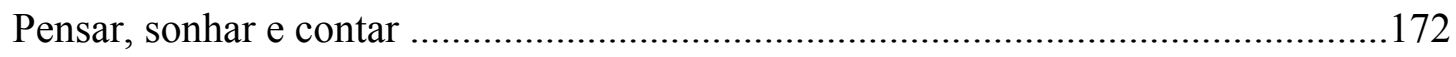

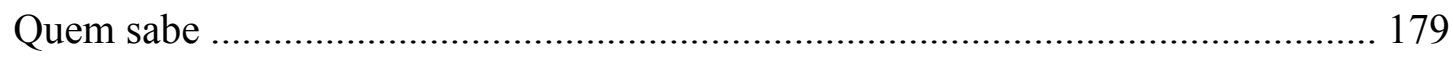

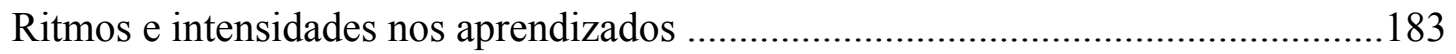

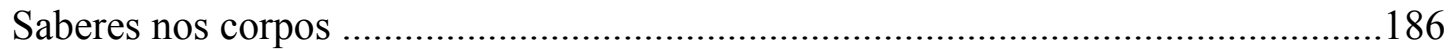

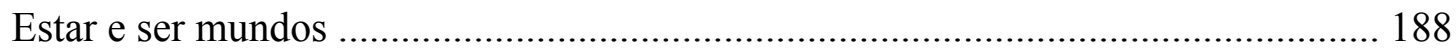

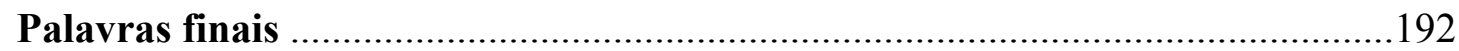

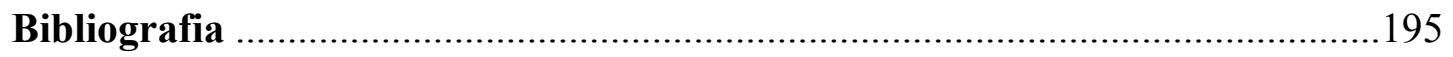

Lista de figuras

Figura 1. Mapa da Terra Indígena Araweté/Igarapé Ipixuna.....................................12 


\section{Introdução}

Esta tese tem como questão central os modos ameríndios de conhecer as florestas ${ }^{1}$ a partir, sobretudo, de conexões estabelecidas com vegetais encontrados na mata e do material levantado durante a permanência em campo entre os Araweté. Florestas, no caso, são abordadas como domínios heterogêneos marcados por descontinuidades e constituídas a partir de sistemas de relações e posições entre humanos e não humanos, que estão calcados em esquemas classificatórios e nas percepções das qualidades sensíveis. A escolha de vegetais como elementos de referência para abordar as redes de relações que compõem as florestas resulta, primeiramente, de um interesse em aprofundar o entendimento sobre o tema a partir de percepções e experiências ameríndias uma vez que essas relações parecem ser menos exploradas pela etnologia americanista quando comparadas, por exemplo, à agricultura e à caça. Florestas e vegetais, no entanto, só fazem sentido, ao menos nesta tese, se abordados a partir das experiências e categorias ameríndias e se forem compreendidos não apenas como lugares, domínios ou seres distanciados, mas como constituídos e enredados em tramas relacionais a partir das dinâmicas da vida social. Dito isso, o foco está justamente nas (rel)ações de diversas ordens tecidas pelos Araweté e outros povos indígenas e em seus modos de conhecer e circunscrever o que denominamos como florestas e vegetais ${ }^{2}$.

Em tempos de movimentos ambientalistas e de discursos sobre catástrofes ambientais decorrentes da ação humana, contexto este associado, superficialmente, nos meios de comunicação e em outras instâncias ao "mau civilizado", que destrói a natureza e ao "bom selvagem" que a conserva e, com isso, impede o desenvolvimento. Sob essa perspectiva, a "natureza" é, em larga medida, tratada de forma distanciada, reconhecida apenas como recurso natural. Esta tese procura, portanto, avançar com o debate no sentido de abordar os modos ameríndios de se relacionarem e constituírem florestas,

\footnotetext{
${ }^{1}$ Neste texto, o conceito de florestas está sendo abordado de maneira ampla, sem o pressuposto de lugar ou ambiente natural. Por envolver categorias lógicas e densas redes de relações, seres e lugares, o substantivo "florestas" sempre será apresentado no plural, como forma de expor, de maneira literal, essa pluralidade de domínios. Também evitarei utilizarei artigos definidos que atuam como determinantes e indicam sentidos individuais aos substantivos. Florestas, para os povos ameríndios, possuem significados que extrapolam conceitos universais.

${ }^{2}$ Faço uso dos termos florestas e vegetais por falta de léxico apropriado. Essa nomeação não busca traçar paralelos semânticos com as noções e formas de classificação da botânica. Neste sentido, uma das dificuldades desta tese foi justamente evitar uma projeção do nosso próprio repertório sobre florestas e vegetais para os contextos ameríndios. Um dos caminhos usados nesta tarefa foi o de seguir as pistas das relações estabelecidas entre os seres.
} 
indo além do entendimento de que as "culturas" alteram ou se adaptam ao ambiente. Sendo assim, os povos ameríndios e a Antropologia têm muito a contribuir nesta reflexão. As etnografias sobre esses povos nas Terras Baixas evidenciam que as relações sociais abarcam domínios mais amplos que a sociedade dos humanos, incluindo, neste contexto, pessoas-vegetais, pessoas-animais e outros não humanos, e que os encadeamentos das (rel)ações entre os diferentes seres produzem efeitos e têm consequências aos envolvidos. Há o reconhecimento de que o entendimento sobre o que é denominado "natureza" nas sociedades ocidentais está, em grande medida, relacionado às construções sociais e dinâmicas relacionais. As conceitualizações sobre o "meio ambiente" apartado da vida social não condizem com concepções ameríndias. Assim, a despeito das condições materiais de existência, não será investido no debate polarizado a respeito de fenômenos naturais ou culturais, de um sujeito espectador ou fazedor, pois não é "ou isto ou aquilo", uma vez que as etnografias demonstram que especialmente entre os ameríndios, corpos e mundos estão plenamente imbricados. Não se trata de "ambientes" onde vivem "seres vivos" que estão à disposição para serem manejados pelos "seres humanos" a partir de seus interesses imediatos. Não se pode ignorar as inter-relações múltiplas e não apenas de ações unilaterais. Neste sentido, as políticas públicas de cunho predominantemente ambientalista, voltadas aos povos indígenas, deveriam ser discutidas e avaliadas levando em conta os saberes e as práticas indígenas, cujas experiências sinalizam outros modos de conceberem e se relacionarem com vegetais e animais, como os que serão descritos nesta tese. As iniciativas que se multiplicam hoje são, sem dúvida, válidas e necessárias, desde que considerem os contextos sociais e políticos e as lógicas e as dinâmicas de engajamento que os povos indígenas estão inseridos.

Há também uma inquietação decorrente da contraposição entre conhecimentos científicos e conhecimentos "tradicionais" e suas formas de produção, transmissão, aplicação e validação. Quase sempre, para o senso comum ou mesmo na elaboração e implementação de políticas públicas, os conhecimentos científicos configuram-se hegemônicos e universais, ao passo que os conhecimentos ditos "tradicionais" são tratados como valores confinados a um passado, sem direito a transformações, sob pena de serem descaracterizados ou esvaziados. Assim, o interesse em investir na compreensão de regimes e modos de produção de conhecimentos por povos de tradição oral, mais especificamente, pelos ameríndios, tornou-se premente. 
A intenção primeira foi caminhar no sentido de compor e dialogar com reflexões e estudos em curso relacionados à problemática desta tese no âmbito da etnologia. E, se possível, mas sem ser esta uma pretensão, o intuito foi colaborar para que as produções antropológicas relativas a povos ameríndios e as próprias experiências desses povos venham cada vez mais subsidiar formulações e implementações de políticas públicas a eles direcionadas e, assim, compor discussões mais amplas sobre temas correlatos.

Desta forma, é fundamental destacar a formação, inspiração e atuação do MARI (Grupo de Educação Indígena), do NHII (Núcleo de História Indígena e do Indigenismo) e, mais recentemente, do CEstA (Centro de Estudos Ameríndios) vinculados, principalmente, aos docentes do Departamento de Antropologia da FFLCH/USP, mas também a outras áreas de produção de conhecimentos, que atuam como centros de pesquisas, debates e engajamento dedicados à etnologia, à história ameríndia e à arqueologia.

Não posso deixar de apontar as contribuições decorrentes da participação na pesquisa temática "Redes ameríndias: geração e transformação nas terras baixas sulamericanas", desenvolvida no âmbito do NHII (USP), sob coordenação das professoras Beatriz Perrone-Moisés e Dominique T. Gallois, especialmente a linha temática coordenada por minha orientadora, que abordou "redes de saberes" e proporcionou a aproximação e debates com Joana Cabral de Oliveira, Ana Martha Tie Yano, Adriana Queiroz Testa, entre outros, bem como o contato com o trabalho de outros pesquisadores que desenvolveram temas correlatos no que se refere à discussão sobre modos ameríndios na produção de saberes. Esses estudiosos são interlocutores e parceiros diretos no resultado desta tese, fato que poderá ser observado ao longo do trabalho. Nos debates do grupo temático tivemos a oportunidade de discutir alguns materiais dos melanesistas sobre regimes nativos de conhecimentos, como, por exemplo, os trabalhos de Marilyn Strathern (2014), as contribuições de Manuela Carneiro da Cunha sobre saberes tradicionais e saberes científicos $(2009,2014)$, noções relativas ao perspectivismo ameríndio desenvolvidas por Eduardo Viveiros de Castro (1996, 2002a,b), as produções de Tim Ingold relativas à "educação para atenção" (2000, 2008, 2010), debates sobre noções de corpo entre os ameríndios e produções dos pesquisadores do grupo, conforme indicado, para citar algumas referências que serão 
expostas e debatidas ao longo desse trabalho. Além dessas influências, o "pensamento selvagem" desenvolvido por C. Lévi-Strauss (2005), noções de socialidade abordadas por Marilyn Strathern (2014b), etnografias que, de alguma forma, abordaram as relações com florestas e vegetais entre os ameríndios, e contribuíram, em grande medida, com a elaboração desta tese.

\section{Nota sobre a pesquisa e a experiência com os Araweté}

Os Araweté ${ }^{3}$, falantes de uma língua tupi-guarani ${ }^{4}$, habitam a Terra Indígena Araweté/Igarapé Ipixuna, localizada na região do Médio Xingu, Pará, entre as Terras Indígenas dos Parakanã, dos Asurini e dos Kayapó-Xikrin, seus inimigos clássicos. Somam hoje cerca de 452 pessoas $^{5}$, distribuídas em seis aldeias ao longo da margem direita do Médio Xingu e do igarapé Ipixuna.

Os Araweté desde o contato com sertanistas da FUNAI (Fundação Nacional do Índio), ocorrido em 1976, permaneceram concentrados em uma única aldeia na margem do igarapé Ipixuna, onde foram reunidos perto de um posto indígena e por lá ficaram por quase três décadas. Posteriormente, deslocaram-se para uma localidade situada a poucos quilômetros de distância, no sentido da foz do rio Ipixuna. Por volta de 2005, começou um movimento de dispersão que culminou com a formação de seis aldeias. Essas aldeias contam hoje com serviços públicos na área de saúde e educação, sendo que, inclusive, alguns Araweté são prestadores de serviço para alguns órgãos públicos - cerca de duas pessoas por aldeia.

Os Araweté são exímios caçadores, coletores e agricultores que habitam uma região de terra firme, onde predomina a floresta tropical com presença de palmeiras e lianas. $\mathrm{O}$ regime de chuvas é bem marcado pela estação seca e chuvosa, e esse movimento

\footnotetext{
${ }^{3} \mathrm{O}$ nome Araweté, atribuído por um sertanista da Funai, não tem significado na língua do grupo. O termo considerado uma autodenominação é bïde, que significa "nós", "a gente", "os seres humanos". Todos os humanos são bïde, mas os humanos por excelência são os Araweté; os outros povos indígenas e os 'brancos' (kamarã) são awi, "estrangeiros" ou "inimigos" (Viveiros de Castro 1986:204-207).

${ }^{4}$ Vale uma nota sobre a grafia dos termos nativos que aparecem em itálico. Busquei seguir a grafia usada por Eduardo Viveiros de Castro (1986) e por Eliete Solano (2009). Contudo, pode haver divergências no modo como foi grafado alguns termos uma vez que não me dediquei ao estudo linguístico da língua araweté.

${ }^{5}$ Dado relativo ao ano de 2013 e obtido no site Siasi/Sesai (Sistema de Informação da Atenção à Saúde Indígena/Secretaria Especial da Saúde Indígena).
} 
colabora para reger a dinâmica da vida social por indicar épocas de pesca, plantio, tipos de caça, de floração e, consequentemente, coleta, sendo também responsável pelo fluxo de água nos rios.

A cidade de referência para os Araweté é Altamira, cujo percurso é feito de barco pelo rio Xingu. Os Araweté frequentam pouco a cidade. Eles costumam ir à Altamira para resolver assuntos ligados à saúde e à aposentadoria, entre outros; quando são acionados para participar de reuniões ou capacitações voltadas à saúde ou educação, por exemplo; ou para fazer compras de mantimentos como café e açúcar ou de outras mercadorias.

É importante dizer, com grande pesar e constatação de impotência, que nessa região os Araweté e demais povos indígenas e ribeirinhos que lá se encontram estão sendo impactados pela instalação da usina hidrelétrica de Belo Monte e seus respectivos projetos de mitigação. A Terra Indígena Araweté não será alagada com a construção da usina, situada a quilômetros dali, sentido jusante do rio Xingu. No entanto, estão aprendendo a lidar com os processos decorrentes de sua implantação, pois serão - para ser mais precisa, já estão sendo - impactados por esse megaempreendimento. Essa é uma situação completamente atípica e extraordinária que está causando profundas transformações na região.

A pesquisa de campo entre os Araweté teve início somente em maio de 2012, em decorrência da demora (de 2010 a 2012) e da dificuldade na obtenção de autorizações governamentais de pesquisa junto a povos indígenas, principalmente por envolver a relação entre povos indígenas e vegetais ${ }^{6}$ - ou, no caso, qualquer patrimônio genético e conhecimento tradicional associado, conforme interpretação oficial ${ }^{7}$-, embora essa pesquisa não tivesse como objetivo levantar possíveis usos dos vegetais pelos Araweté.

\footnotetext{
${ }^{6}$ A presente pesquisa obteve autorização dos Araweté, da FUNAI e do IPHAN/CGEN (Instituto do Patrimônio Histórico e Artístico Nacional/Conselho de Gestão do Patrimônio Genético). Os processos de emissão de autorizações demoraram cerca de dois anos, de 2010 a 2012, situação que, por sua vez, gerou atraso no andamento da pesquisa. Embora legítimos, esses trâmites deveriam ter maior celeridade e simplicidade visando a garantia dos direitos dos envolvidos, mas também prezando pela dinâmica dos processos de pesquisa que seguem normas e tempos institucionais. No entanto, é fundamental agradecer àqueles que a partir das instituições onde atuam estiveram envolvidos nesses trâmites e se dedicaram para o desenrolar dos processos, inclusive da parte do PPGAS-USP/Programa de Pós-Graduação em Antropologia Social e do setor de administração da FFLCH - Faculdade de Filosofia, Letras e Ciências Humanas da USP.

${ }^{7}$ Medida Provisória n $n^{\text {o }}$ 2.186-16, de 23 de agosto de 2001, que foi substituída pela Lei n ${ }^{\mathrm{o}} 13.123$, de 20 de maio de 2015.
} 
Assim, o primeiro contato mais sistemático com os Araweté se deu entre o mês de maio e o início do mês de junho, de 2012, quando permaneci nas aldeias Ta'akati e Arajity, ambas localizadas na margem direita do rio Xingu. Outros períodos de permanência em campo foram no mês de outubro do mesmo ano, na aldeia Djuruanti, localizada na foz do igarapé Ipixuna, quase no encontro com o rio Xingu, e entre o mês de fevereiro e o início do mês de março de 2014, quando retornei à aldeia Ta'akati.

Esse período junto aos Araweté, apesar de limitado para a elaboração de uma etnografia centrada nesse povo (tarefa que não foi o propósito desta tese), possibilitou traçar alguns caminhos e construir argumentos, ainda que de maneira sintética, para o desenvolvimento da pesquisa e, com isso, delinear a estrutura da tese.

De antemão, buscava compreender o modo como os Araweté percebiam o domínio das florestas e as concepções e relações com os vegetais. Este foi o recorte inicial. Para tanto, seria necessário participar ativamente das incursões na floresta. Aos poucos, percebi que as possibilidades de participar desses momentos seriam limitadas e que as incursões nas florestas eram apenas parte dos modos de conhecer esse domínio. Dois esclarecimentos são necessários fazer, os quais, de certa forma, são centrais nesta tese. O primeiro deles relaciona-se ao entendimento de que não se trata de estudar florestas, mas sim de compreender as relações sociais e percepções que constituem tais florestas por isso o uso no plural -, às quais são caracterizadas ao mesmo tempo que compostas por descontinuidades de diversas ordens. Neste sentido, dada a vastidão das florestas e das relações que as constituem e a limitação desta pesquisa, as concepções e conexões estabelecidas a partir dos vegetais, principalmente, propiciaram identificar apenas algumas dessas descontinuidades. A outra questão está ligada, justamente à percepção de que para aprender a caminhar nas matas, caçar, coletar mel, castanha, açaí etc., não basta apenas estar nas florestas, a despeito desta condição ser indispensável. Tal observação é válida, no entanto, apenas para povos cuja vida social não se restringe às florestas. Assim, a fabricação de corpos e a constituição de relações para a produção de pessoas, em todos os âmbitos e fases da vida social, são imprescindíveis aos modos de conhecer as florestas. Por fim, restava então desenvolver modos de constituir saberes entre os ameríndios, dado que, mais uma vez, não cabia restringir esse tema às florestas. 
Sendo assim, esta tese investe basicamente em duas frentes: circunscrever florestas e associações com vegetais a partir de relações e percepções ameríndias como apresentado nos capítulos I e II. Neste sentido, perseguir diferentes caminhos e conexões pareceu desestabilizar fronteiras entre floresta e roça, floresta e aldeia, animais e humanos, por exemplo. Por sua vez, modos de conhecer e de desenvolver capacidades e, consequentemente, aprender a andar nas florestas são totalmente intrínsecos às redes sociocosmológicas e aos processos de constituição de corpos e gentes, conforme indicado nos capítulos III e IV. Assim, o ponto de partida foi circunscrever concepções sobre "florestas" e "vegetais" segundo etnografias e percepções ameríndias, tendo como referência as redes de relações vigentes. Não pretendi empreender uma tradução desses termos, mas justamente alargar o seu entendimento no intuito de compreender como alguns povos indígenas percebem, organizam, se relacionam e, sobretudo, aprendem a andar nas florestas. Fica, então, evidente que para acessar os modos ameríndios de conhecimento não se pode estar descolado dos contextos relacionais, dos planos empíricos e das formas de organizar os seres e as coisas. Por isso, o investimento inicial em compreender as relações estabelecidas com os seres que constituem as florestas e, em especial, os vegetais.

Assim, vale dizer que houve um esforço para entender florestas e vegetais não como categoriais dadas, o que, diga-se de passagem, é um exercício reflexivo por serem noções bastante enraizadas, nos colocando desafios e novas perspectivas de compreensão. Para tanto, investi em qualificar o domínio das florestas e as relações com os vegetais a partir de categorias e experiências ameríndias.

No entanto, dada a limitação da permanência em campo, que teve como foco tanto a vida social nas aldeias quanto algumas experiências nas florestas, busquei ampliar o campo entre os Araweté a partir do trabalho desenvolvido por outros etnógrafos, como veremos a seguir.

\section{Do concreto ao compartilhado a partir de bases etnográficas}

O propósito deste trabalho foi, então, colaborar e compor com os estudos relativos a regimes ameríndios de conhecimentos e contribuir no sentido de adensar os materiais etnográficos que abordam experiências ameríndias relativas às florestas e cadeias 
associativas envolvendo vegetais. Para alcançar esses objetivos, parti, como indicado, da experiência de campo entre os Araweté, mais especificamente, do aprendizado com pessoas com quem tive mais contato: moradores das aldeias Ta'akati, Arajity e Djuruanti, e de materiais etnográficos diversos focados, sobretudo, na Amazônia e nos Tupi-Guarani (Viveiros de Castro 1986; Gallois 1988; Garcia 2010; Figueiredo 2010; Oliveira 2012; entre outros). Materiais etnográficos elaborados a partir de concepções de nativos melanésios (Strathern 2014a; Wagner 2010), para além de seus contextos particulares, contribuíram para iluminar algumas questões, como a noção de socialidade. Também tomei a liberdade de ampliar a base etnográfica (Maizza 2009; Yano 2010 e 2014 etc) pelo fato dos materiais selecionados contarem com valiosas contribuições para a compreensão de concepções sobre o domínio das florestas e relações com vegetais ou dos modos ameríndios de conhecer, por exemplo.

As incursões nessas etnografias me permitiram partir das experiências relatadas pelos autores, que forneceram pistas e dados para compor o percurso desta tese. Para evitar interpretações errôneas, é importante ressaltar que quando busco informações, descrições a análises a partir de materiais etnográficos, relativos a outros povos indígenas, deixo claro que não se trata do ponto de vista daqueles que participaram ativamente das pesquisas como interlocutores, mas dos autores das etnografias. A intenção, tampouco, foi totalizar os povos indígenas mencionados nesta tese. As narrativas elaboradas a partir de experiências dos antropólogos entre os povos indígenas têm como base a interlocução estabelecida com algumas pessoas e famílias que se identificam como parte dos grupos com os quais são realizadas as pesquisas, cujas relações particulares "[...] nos farão perceber relacionamentos significantes" (Strathern 2013:128). Esse processo decorre de intercâmbios de experiências entre sujeitos que estão em diferentes contextos (op.cit.:76-77;82-85) e tem como propósito exprimir "os mundos" dos outros a partir de conexões parciais marcadas por justaposições e discrepâncias. Não pretendi, de forma alguma, esgotar os materiais etnográficos que poderiam contribuir com o desenvolvimento das problemáticas propostas, mas, diante dos limites impostos, acredito ter me apoiado em um conjunto de materiais significativos, focado, principalmente, nos povos indígenas cujos modos de vida são fundados na relação com florestas, e que continuam operando suas próprias cosmologias e práticas de conhecimentos. Outra questão importante a ser esclarecida é que não foi feita uma descrição e análise minuciosas dos pressupostos e interesses das 
etnografias consultadas, cujos materiais etnográficos e elaborações teóricas foram usados no sentido de compor e dar consistência à problemática abordada nesta tese.

Análogo aos fios entrelaçados na tessitura de redes, persegui conexões que de modos assimétricos operam relações diferenciais que, como diz Goldman (2006) acerca da teoria etnográfica, para além de um contexto particular, são "[...] capazes de conferir inteligibilidade aos acontecimentos e ao mundo" (2006:171). O esforço em traçar conexões, e não em buscar padrões, escapa também de generalizações fugazes. No entanto, conectar perspectivas que embora não se definam completa e mutuamente acaba por fornecer pistas que se desdobram em extensões compartilhadas. Essas conexões estabelecidas a partir de bases etnográficas reforçam contextos de interações e permitem, de certa maneira, realçar similaridades e acomodar possibilidades de diferenças. Com isso, pretende-se minimamente ordenar aquilo que é experimentado no bojo dos modos de vida próprios aos ameríndios, o que não significa meramente uma promoção de equivalências e totalizações. Assim, é possível associar, por vezes, semelhanças, tarefa que exige cautela e não visa apagar as dissonâncias, mas que contribui para tornar robustas algumas percepções e considerações pertinentes ao desenvolvimento de argumentos relativos aos modos ameríndios de conhecer. 


\section{Localização da Terra Indígena Araweté Igarapé Ipixuna no estado do Pará}

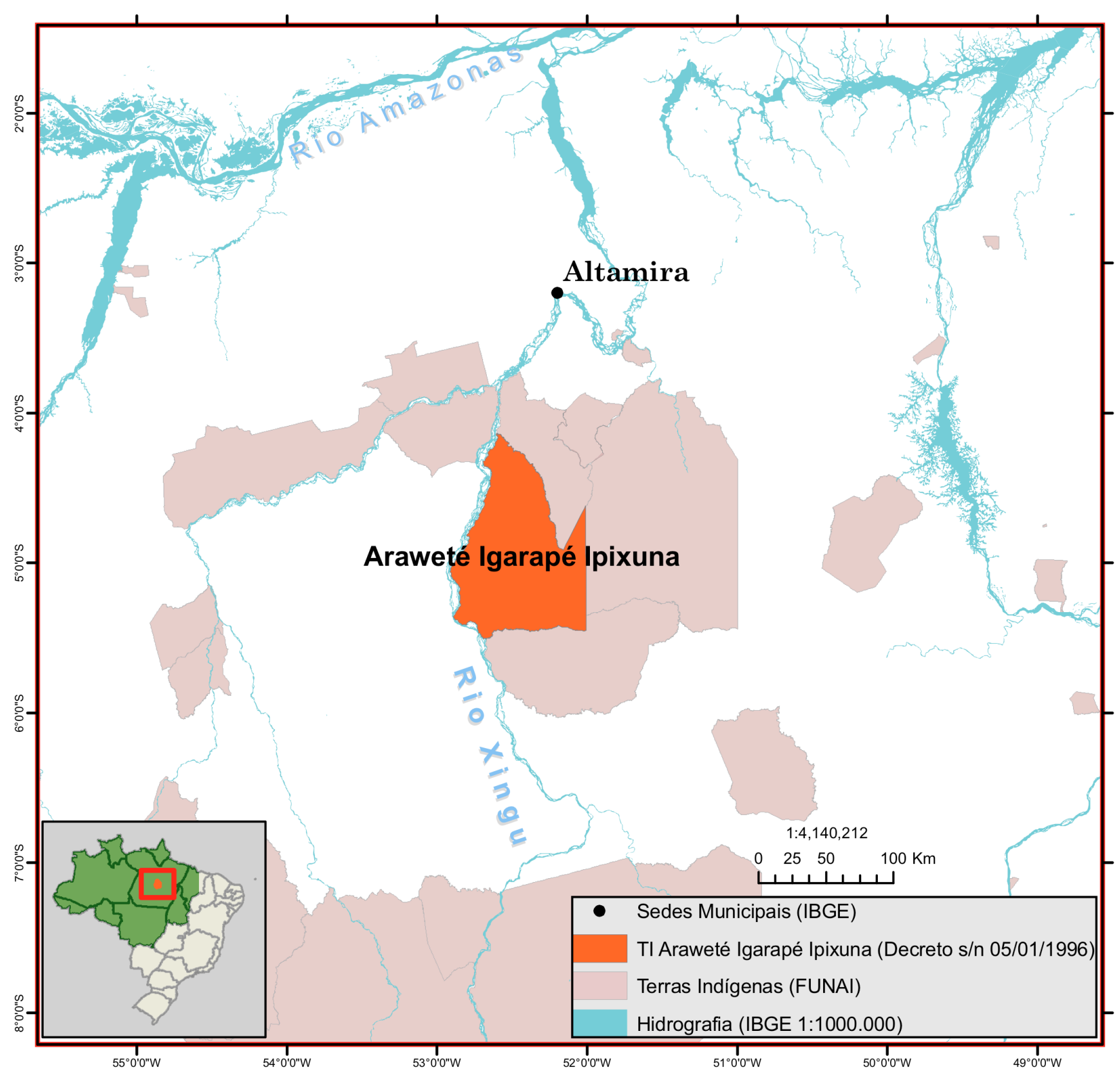




\section{Capítulo I - Sobre descontinuidades nas composições das florestas}

Experiências sinestésicas, acontecimentos, histórias de caçadas, derrubadas de mata, plantios, conflitos, lembranças de parentes, "namoros", relações de perigo e cooperação, desenham e compõem as dinâmicas entre os seres no domínio das florestas entre os ameríndios. A imagem atribuída às florestas por aqueles que dela estão distantes, tendo este espaço como um lugar desconhecido, restrito a fatores ecológicos e geológicos, sem ruídos, cheiros, sabores, rastros, prazeres, perigos, "gentes" e relações, é desfeita nas dinâmicas ameríndias que abarcam implicações mútuas entre os seres e os elementos que constituem as florestas.

Florestas configuram-se como domínios onde são vivenciadas relações de cooperação, mas também de agressão e perigo, travadas entre seres visíveis e invisíveis, tais como as onças, as cobras e os espectros inimigos, ou entre donos e xerimbabos, como serão abordadas nesse capítulo. Assim, a partir de diferentes posições instituídas por intercâmbios cosmológicos e tramas sociais experimentadas na vida cotidiana, fica evidente que não é pertinente tratar o domínio da floresta como um operador absoluto, homogêneo e contínuo, indicando a extrapolação da ideia de que a natureza é única e externa, ou até mesmo da ideia de "natureza". O pressuposto de uma natureza-objeto separada da sociedade é algo estranho às "[...] cosmologias das sociedades amazônicas, que fazem do universo uma totalidade social regida por um complexo sistema de intercâmbios simbólicos entre sujeitos humanos e não humanos, sistema do qual o xamanismo é a pedra de toque" (Albert 2002:257). A despeito de aspectos físicos e ecológicos - o que não significa dizer alheios a eles -, outras lógicas pautam as formas como os ameríndios percebem, exprimem, circulam e produzem a vida no que denominamos de florestas. Entre os povos indígenas, as florestas e seus componentes não são concebidos meramente como recursos naturais ou lugares instituídos a partir de padrões universais. Florestas são construções categóricas complexas - aproveitando uma expressão empregada por Ellen $(1996)^{8}$ - que envolvem categorias lógicas e densas redes de relações, seres e lugares.

\footnotetext{
8 Este artigo de Roy Ellen foi traduzido por Marcos Paulo Cimo, aluno do curso "Antropologia e Desenvolvimento" ministrado por Dominique T. Gallois, na Universidade de São Paulo, em julho 2007. Pelo fato da tradução não estar publicada, cito o artigo de Roy Ellen, apoiando-me na versão em português.
} 
Para fazer uma abordagem sobre florestas, que não serão tratadas como uma referência em si, mas a partir das expressões e manifestações ameríndias, é importante dialogar com algumas noções analisadas pela antropologia acerca dos lugares e das paisagens. Para além da compreensão dos lugares como expressões de sociocosmologias ou de uma "geografia xamânica" 9 , noção tão bem aplicada ao Noroeste Amazônico (Cayón 2010; Århem 1998), ou como escrituras históricas a partir de uma topografia dada entre os Yanesha, habitantes da Amazônia peruana (Santos-Granero 1998), os lugares são imbricados em um campo de relações e interações que envolvem aspectos físicos, fenomenológicos, cognitivos (Basso 1996) e ontológicos.

Tim Ingold, ancorado em uma perspectiva ecológica e na antropologia da prática (2000; 2010), enfatiza o fato de sermos 'seres-no-mundo', perspectiva que não privilegia nem a natureza nem a sociedade, mas a interação entre ambas. No contexto de engajamento das pessoas no mundo, os lugares ganham seus significados. Não se trata de inscrever um modo de vida sobre um suporte físico passivo (o que não é fato, pois todos os seres têm seu próprio ritmo e movimento), mas de ressaltar essa dinâmica múltipla. Ingold desenvolve então a noção de paisagem enquanto processo que abarca vidas em movimento e não como imagens estáticas percebidas por um observador externo. Para Ingold (1993), paisagem não é terra - quantitativa e homogênea -, nem natureza enquanto mundo objetivo e físico - e nem espaço - enquanto representação de morar no mundo. As paisagens estão relacionadas a aspectos qualitativos e heterogêneos e estão implicadas na interação entre organismo-ambiente sendo parte de nós como somos parte dela.

Nesse sentido, pode-se afirmar que a maneira como os Araweté, tal como os Awá, relacionam-se com o espaço não está vinculada a uma geografia mítica ou a espaços fixados, mas a características e situações circunstanciais, em um plano mais perceptivo. Entre os Araweté, como entre os Awá, memória e espaço estão intrinsecamente implicados (Viveiros de Castro 1986:173, 182; Garcia 2010:60). Para os Araweté,

\footnotetext{
${ }^{9}$ Noção usada na etnologia do Noroeste Amazônico sendo abordada por Cayón "[...] como um aspecto que fundamenta a estrutura da realidade, vincula as pessoas com o espaço em que vivem, dá-lhes um lugar no cosmos e as relaciona com outros seres, humanos e não humanos, que povoam o universo" (2010:210). Ao estudar a teoria makuna do mundo, Cayón (2010) indica que os lugares seriam antes manifestações do Pensamento (ketioka), uma dimensão polissêmica da realidade que se apresenta como uma forma de ser e de subjetividade voltada a dar vida ao universo, aos seres e às pessoas pelo conhecimento, habilidade, agência, criatividade e multiplicidade. Nesse sentido, espaço e ketioka estão totalmente imbricados, se autoconstituem e são entendidos como componentes dos cosmos e das pessoas.
} 
topônimos e aldeias podem ser referenciados pelo nome de uma espécie vegetal, por uma ação marcante ocorrida no local, por particularidades topográficas, por nomes de antigas aldeias, como Ta'akati, ou pelo nome de uma pessoa que faleceu naquele lugar (Viveiros de Castro 1986:170). Assim, "[...] o espaço geográfico é integralmente investido pela memória coletiva, e notadamente pela memória da morte de membros da tribo. É, porém, uma memória puramente linear, que se conforma à trajetória dos vivos no espaço. Não existem, seja no território atual, seja na lembrança dos mais velhos, sítios ou acidentes geográficos individualizados e dotados de valor mítico" (op.cit.:173).

Como então (de)compor os domínios das florestas não a partir de um lugar previamente dado, homogêneo ou de um a priori conceitual? Nesse sentido, vale reforçar que "[...] as condições naturais não são aceitas passivamente. E o que é mais, elas não têm existência própria, pois são função das técnicas e do gênero de vida da população que as define e que lhes dá um sentido, explorando-as numa determinada direção. A natureza não é contraditória em si; ela só pode ser em termos da atividade humana particular que nela se inscreve; e as propriedades do meio adquirem significações diferentes segundo a forma histórica e técnica de que se reveste este ou aquele gênero de atividade. Por outro lado, e mesmo promovidas ao nível humano que, só ele, pode lhes conferir inteligibilidade, as relações do homem com o meio natural desempenham o papel de objetos de pensamento; o homem não as percebe passivamente, ele as tritura depois de tê-las reduzido a conceitos, para deles inferir um sistema que nunca é predeterminado [...]" (Lévi-Strauss 2005:111).

A partir de bases etnográficas, a atenção estará voltada para as associações estabelecidas especialmente a partir de redes de relações que envolvem vegetais para identificar e buscar "[...] quais são os factos, e os critérios, variáveis de uma cultura para outra, em virtude dos quais cada uma escolhe certas espécies animais ou vegetais, certas substâncias minerais, certos corpos celestes e outros fenômenos naturais, para os dotar de uma significação e pôr em forma lógica um conjunto acabado de elementos" (LéviStrauss 1986:151/152), que neste caso estão relacionados aos modos como os ameríndios percebem e constituem florestas.

Assim, as florestas são compostas por sistemas e redes descontínuas, que surgem a partir de experiências perceptivas subjetivas e são também informadas por referências e 
padrões lógicos. É da intersecção desses múltiplos planos que são atribuídos os sentidos do que está sendo denominado como florestas, cujas características não são definidas por si mesmas, mas sempre em relação a alguém ou a alguma coisa e a partir de redes de relações. Nesse capítulo pretende-se traçar alguns planos dessa tecitura no intuito de constituir florestas não somente como um "lugar", mas a partir da decomposição de categorias lógicas e campos perceptivos e relacionais. Dessa forma, descontinuidades apreendidas por meio da percepção compõem categorias de pensamento que tecem entendimentos do que pode ser denominado como florestas. Vivências, caçadas, cadeias relacionais, categorias de oposições como nós e outros, plantado e não plantado, a formação de "acampamentos-aldeias", enfim, o entrelaçamento entre planos diversos colabora com a constituição dessa categoria que pode ser qualificada como complexa e está sujeita à campos de negociações.

Assim, partiremos da cosmogênese e do processo de especiação para adentrar neste domínio e iniciar o desvendamento das redes, códigos e relações que o compõe.

\section{Cosmos e florestas}

"É a mesminha, ele está dizendo, a floresta debaixo! É a mesminha floresta", afirmava Araparawi ao acompanhar e traduzir a conversa com o seu pai, Tatua $\mathrm{ru}^{10}$, que mencionava a presença de castanheira, babaçu, arahu'i (tipo de árvore), mata, palha, terra, estrela, mel e peixe, tanto na camada subterrânea, quanto nas camadas celestes do cosmos, semelhante às florestas encontradas no domínio terrestre.

"Mai ${ }^{11}$ morava nesta terra. Mai destruiu outra terra e mandou esta terra subir. Esta terra subiu com tudo, árvores e bichos. Tem jati ('jaboti') grande, ja'i ('castanha'), nata'i ('pé de babaçu'), arahu, kopi ('cupuaçu'), atfa'i ('açaí')... Pajé disse que no Mai pi (lugar dos deuse' $^{12}$; primeira camada celeste) bichos ficam cercados. Embaixo tem outra terra igual; tem rio grande, igual ao mar. Embaixo também tem tudo, ja'i, nata'i,...; embaixo

\footnotetext{
${ }^{10}$ Tatua ru é um ancião araweté que reside na aldeia Ta'akati. Conversa realizada em fevereiro de 2014.

${ }^{11}$ Mai são humanos que se transformam em deuses após a morte; são seres imortais que se foram da terra na separação original; são belos, fortes, apresentam potência xamânica e sexualidade exacerbadas (Viveiros de Castro 1986:212). Para aprofundar sobre esta e outras categorias araweté que povoam o cosmos, consultar Viveiros de Castro (op.cit.:204-230).

${ }^{12}$ Mai pi, lugar dos deuses, é de todas as camadas a mais importante. Seria o céu que é visível para nós, segundo Viveiros de Castro (1986:186).
} 
tem Taraju, não tem gente, só tem Mai". Nesta breve conversa sobre a constituição das camadas celestes e subterrâneas, Jadimaru ${ }^{13}$ conta que um "terremoto" ocorrido distante de onde estávamos - aldeia Djuruanti Araweté - fez a terra tremer e desabar ${ }^{14}$. Não ficou claro se o "terremoto" foi provocado por Mai, mas o fato é que todos ficaram com muito medo e tentaram se proteger. Alguns subiram no nata'i ('pé de babaçu') que, devido ao peso, se quebrou. Outros se refugiaram em barcos para aguardar o terremoto passar. Somente quem subiu no pé de bacaba, no ápice da folha, se salvou. Grandes piranhas e jacarés comeram muita gente. Sucuri também comeu muita gente. A partir desses eventos, segundo Jadima ru, decorre a formação das ilhas onde são encontrados jaboti, paca e cotia que lá ficaram. As matas também foram destruídas no terremoto e depois "veio nascendo sozinha, veio dançando. A raiz fez crescer, igual quando capina e depois começa a crescer", disse Jadima ru.

Em outra versão sobre a formação das camadas celestes e subterrânea, a separação ocorreu devido a um dilúvio provocado pelo canto de um homem, com apoio de seu sobrinho, ao se sentir insultado pela esposa. Assim o solo de pedra se ergueu e formou a abóboda celeste que foi habitada por grupos de Mai - termo traduzido na literatura Araweté por "deuses" - e outras categorias de seres. Outros Mai formaram a segunda camada celeste. $\mathrm{Na}$ terra, grandes jacarés e piranhas comeram os humanos. Restaram apenas dois homens e uma mulher que se salvaram ao subirem em um pé de bacaba. Estes são considerados os ancestrais da humanidade. Outros seres afundaram na água e formaram o mundo subterrâneo. Esse momento é percebido como o tempo de dispersão dos diferentes grupos que gerou a divisão entre homens e Mai e a diferenciação sociológica na terra (Viveiros de Castro 1986:184-188).

Para os Araweté o cosmos é composto por camadas superpostas distribuídas entre os patamares terrestre, suporte dos humanos, subterrâneo e celestes, sendo estes últimos lugares de moradia dos deuses. Humanos e aqueles que se tornariam deuses viviam juntos na terra. A oposição céu/terra assume um valor central para os Araweté e marca a

\footnotetext{
${ }^{13}$ Jadima ru é também um ancião araweté, irmão de Tatua ru, que reside na aldeia Djuruanti. Este relato foi feito em outubro de 2012, quando passei cerca de um mês nesta aldeia Araweté. Jadima ru disse que seu avô contava essa história para que ele sempre se lembrasse dela.

${ }^{14} \mathrm{O}$ 'terremoto' ocorrido no tempo mítico. Quando disse que Xingu devastou tudo, a situação foi comparada ao terremoto que devastou parte da costa do Japão em março de 2011. Não foi indicada uma palavra na língua Araweté para expressar o termo 'terremoto'. Essa palavra não foi usada conforme o seu sentido literal, mas como uma aproximação da utilizada localmente para dar a dimensão da destruição ocorrida.
} 
separação fundante entre humanos e deuses e vivos e mortos (op.cit.:197). Como destaca Viveiros de Castro, o universo cosmológico Araweté não se restringe aos eixos verticais e a uma noção de camadas superpostas, uma vez que seus valores se misturam aos do sistema horizontal de oposição e mostram que "[...] por exemplo, as diferentes raças de deuses do Maï pi estão a distâncias diferentes do mundo humano - tanto no eixo horizontal quanto vertical - apesar de habitarem o "mesmo" patamar. Os valores verticais e horizontais dos cosmos se misturam ou interinfluenciam, e as qualidades simbólicas do espaço distorcem qualquer neutra geometria." (1986:188-189).

Nas cosmologias tupi-guarani, a despeito de diferenças significativas que guardam entre si, a oposição céu/terra pode compor com sistemas horizontais marcados pelas relações entre humanidade e animalidade e expressos pelos pares mata/aldeia, floresta/água ou aldeia/roça/mata (op.cit.:203). Se entre os Araweté a camada terrestre é associada aos humanos, é preciso enfatizar que os deuses, espíritos, animais e vegetais estão presentes em todas as camadas, sendo que o entendimento dessas noções dependem largamente de contextos de contrastes (op.cit.:204-205).

Conexões entre os domínios que compõem os eixos vertical e horizontal e as relações que os transpassam serão abordadas, conforme já dito, tendo como ponto de referência as florestas terrestres e as relações que as envolvem conforme as manifestações e vivências dos Araweté. O intento aqui é deslocar e ampliar a rede calcada na oposição humanos/animais e focar nas dinâmicas e arranjos estabelecidos pelos povos indígenas, principalmente amazônicos, tendo como elemento norteador relações que envolvem espécies vegetais encontradas nas florestas terrestres. Vale notar que em certas circunstâncias espécies vegetais encontradas nas florestas terrestres participam de arranjos que transcendem as relações instituídas entre os seres que se encontram na camada terrestre, como veremos, por exemplo, nos capítulos II e III.

A formação de diferentes patamares ${ }^{15}$, domínios e a própria especiação sociológica dos seres ocorreu, em geral, em decorrência de transgressões ou abusos de diversas ordens empreendidos pelos humanos. Os relatos indicam que eram mundos sem morte e sem

\footnotetext{
${ }^{15}$ Não são em todos os contextos ameríndios que os patamares estão distribuídos em camadas celestes, terrestres e subterrâneas, como no cosmos pirahã "[...] onde não há oposição entre céu e terra, tendo como única referência as terras que se superpõem conformando um Cosmos 'folheado'" (Gonçalves 2001:142).
} 
trabalho - ou quase sem trabalho, pois os Awá caçavam (Garcia 2010) -, sem fogo e sem plantas cultivadas (Viveiros de Castro 1986). A mitologia Wajãpi indica que "[...] homens e animais partilhavam também o mesmo espaço, ainda indiferenciado, delimitado apenas por um único rio; naquela época, ainda não havia floresta como a que conhecemos hoje: todas as árvores eram baixas e pouco diferenciadas." (Gallois 1988:42).

Relatos de que no tempo das origens, animais, espécies vegetais e outros seres compartilhavam atributos de uma mesma humanidade, como a capacidade de comunicação e a semelhança entre os $\operatorname{corpos}^{16}$ são correntes nas etnografias ameríndias. Com a diferenciação dos domínios e o processo de especiação foi interrompida a proximidade e a comunicação que vigorava entre todos, situação que abriu espaço para relações de predação (Gallois 1988:43). Os diferentes domínios são, então, ocupados por humanos e não humanos que correspondem a diversas categorias de alteridade marcadas pelo distanciamento entre elas. Neste contexto, são formados os domínios das florestas na camada terrestre onde, de forma geral, foram acomodados animais, vegetais e espectros terrestres - ajã, espectro dos mortos e espíritos malignos entre os Wajãpi; Ani, seres perigosos para os humanos, entre os Araweté; ajy, seres de alma morta e protetores dos animais mais caçados pelos humanos entre os Awá, para citar alguns exemplos tupi-guarani.

Em outros contextos etnográficos, para citar alguns, como entre os Araweté, também foi relatada a presença de florestas e dos seres que as constituem nos patamares celestes e subterrâneos, configuração nem sempre explorada nas etnografias ameríndias e que, por vezes, poderá atuar em contraponto à dinâmica e características que envolvem os seres encontrados nas florestas presentes nas camadas terrestres. De sua parte, o cosmos vivido pelos Awá é constituído por infinitos iwá ("céu") que contam com a presença dos karawá, categoria complexa de seres, que podem, de maneira simplificada, serem entendidos como os awá celestes (Garcia 2010:75). A dieta dos karawá é composta por cultivares e frutos de maior porte e mais carnudos, de produção perene e mais fáceis de acessar, pois no iwá, árvores e palmeiras são mais baixas (op.cit.:235). Já a caça e o mel

\footnotetext{
16 Entre os Araweté "Os animais criados eram humanos, antigamente. Durante uma grande festa de cauim, a divindade Nã-mai ("deus-onça", o irmão de Mikora'i, o "filho do gambá"), vingando-se da morte de sua mãe nas garras da $\tilde{N} \tilde{a}$ nowï'hã, a onça monstruosa, transformou-os todos nos animais de hoje [...]" (Viveiros de Castro 1986:224).
} 
são obtidos pelos karawá na terra. Entre os Jarawara, moradores no Médio Purus, no patamar celeste também é observada a presença de diferentes domínios, inclusive florestas, semelhantes àqueles encontrados na camada terrestre. No entanto, nesse patamar habitam animais, árvores e plantas - denominação esta empregada pela autora espíritos de mortos, espíritos-de-plantas e árvores, denominados inamati, e yama, seres com aparência de animais. No céu todos são jovens e não adoecem. As "árvores e plantas" apresentam maior vigor e maior porte. O céu é marcado pela fartura, mas também por brigas recorrentes entre os espíritos. Vegetais também são encontrados na camada denominada 'abaixo da terra', onde há a presença de plantas tubérculos e de espíritos-velhos (Maizza 2009:57-63). O cosmos enawene-naue é composto de quatro patamares, sendo que o patamar terrestre apresenta características similares ao primeiro patamar celeste, denominado eno, habitado por belos 'deuses celestes', 'almas' de animais e uma vegetação exuberante. "No eno, do qual o patamar terrestre é apenas uma imitação e reflexo, vivem (as almas de) animais de todas as espécies; a vegetação é exuberante e sempre verde, a terra incomparavelmente fértil e constantemente cultivada (Mendes dos Santos 2006:52).

De volta aos Araweté, Tiñarai du ${ }^{17}$, pajé que reside na aldeia Arajity, relatou que "no Mai pi tem roça grande que trabalha sozinha, ninguém precisa fazer nada". Disse: "Tu mesmo vai trabalhar sozinha". E acrescentou: "Está bom! Ninguém faz comida no Mai $p i$. Sozinho faz tudo. Lá tem mamão, mandioca, abacaxi grande, tudo tem. Embaixo da terra tem pessoa também, não é $M a i$, é outro tipo. Lá tem $k a^{\prime} a$ ('floresta'), tem peixe, igual no Mai (está se referindo ao primeiro céu) para nós; lá tem Mai, é embaixo da terra. Se a terra cai, cai tudo no fundo. No Mai pi não morre não; osso fica no Mai pi e fica bom de novo ${ }^{18}$. No Mai pi tem $k a^{\prime} a$ ('floresta') e jate ('jaboti') grande. Tem só jaboti criado. Lá tem ja'i ('castanheira') grande, o pau é grande como uma casa. Lá tem abóbora grande, banana grande, jiti ('batata-doce') grande e milho grande" ${ }^{19}$. Esse relato indica características presentes na camada celeste muito similares às notadas em outros contextos etnográficos, como demonstrado acima. Vale ainda dizer que, embora no Mai

\footnotetext{
${ }^{17}$ Todo os relatos e conversas estabelecidas com o pajé Tiñarai du foram realizados quando permaneci cerca de um mês em campo, nas aldeias Ta'akati e Arajity, entre maio e junho de 2012.

${ }^{18} \mathrm{O}$ tema da transformação dos homens após a morte no Mai pi, que é feita a partir dos ossos do ombro, é tratado por Viveiros de Castro (1986) e não será abordado nesta tese.

${ }^{19}$ Tiñarai du ao dizer que o jaboti que mora no Mai pi é grande, riscou no chão de terra um jaboti do tamanho encontrado no Mai. O casco do jaboti devia ter mais de um metro de diâmetro. Disse-me também que não come nada que mora no Mai pi, pois faz mal e provoca doença. Por ser pajé, ele tem acesso ao Mai pi.
} 
pi os deuses não cacem jabotis por apresentarem características magnificadas, além de serem seres criados (tema que será tratado no capítulo III), "[...] no céu, mundo bemaventurado dos mortos e dos deuses, não há agricultura, pois as plantas crescem sozinhas; mas todos caçam. Os deuses são caçadores, não agricultores." (Viveiros de Castro 1986:153).

Kuruamaru, morador da aldeia Djuruanti ${ }^{20}$, contou-me que no Mai pi tem morerawi ("fruto que jaboti come"), arakatuã (tipo de mamão que fica na mata, indicado como comida de jaboti), petitini (árvore que produz uma flor amarela, comida de jaboti), akao ti (akao, "cacau" e ti, "coletivo"; "cacaual”), onça, jacaré e que na camada subterrânea tem tudo o que tem na terra, pidã ("peixe”), mitum ("mutum”) e nata'i ("babaçu”).

Mai e os mortos habitam a primeira camada celeste. O mundo celeste é um lugar de caçadas, danças e festas; seus habitantes são esplendorosos, belos e mais perfeitos que os humanos e estão sempre pintados de jenipapo, adornados e perfumados. Nessa camada há superabundância, tudo é grande e permanente, não há falta comida e bebe-se bastante cauim - bebida fermentada de milho. No "Maï pi tudo é muito maior, do milho às castanheiras -, $[. .$.$] lá a mata não tem cipó, anda-se sob as árvores como aqui nós na$ aldeia; lá os machados e facões trabalham sozinhos, o milho se planta por si..." (Viveiros de Castro 1986:219-220). Lá os deuses moram em aldeias e caçam nas matas.

Se, como indicado nos materiais etnográficos, de alguma forma, as florestas manifestam certa semelhança nos diferentes patamares, vale destacar que espécies vegetais ressaltadas por serem foco de interesse nesta tese -, na camada celeste, especialmente em contraposição à camada terrestre, além de serem comestíveis e de fácil acesso, apresentam características magnificadas e criam-se a si mesmas.

Em conversa com Tiñarai du sobre a formação das florestas na camada terrestre, Mai aparece como aquele que ao subir ao céu deixou tudo o que está na terra para os humanos. Os $M a i^{21}$, na separação original, foram embora da terra, sobretudo para o primeiro patamar celeste, e "abandonaram" seres e coisas na terra. "Mai manda criar

\footnotetext{
${ }^{20}$ Kuruama ru um homem jovem, casado, morador da aldeia Djuruanti. Conversa realizada durante atividade de campo feita em outubro de 2012 entre os Araweté.

21 "Os Mä̈, os humanos, os espíritos da mata e da água são entes que sempre existiram, não foram criados, não foram criados; assim também certos animais [...]." (Viveiros de Castro 1986:223).
} 
banana $^{22}$. Mai dá para a gente de presente tudinho. Mai deu tudo. Mai deu todas as plantas $^{23}$. Mai deixou as plantas aqui. 'Bicho', $A n i^{24}$, não. Foi Mai que deixou. Ani não gosta não, não é amigo de Mai. Não é amigo de ninguém, mata muita gente [...] Ani mata na aldeia e mata no mato". Ao ser indagado se tem muito Ani na camada terrestre, Tiñarai du diz: "Tem demais, igual branco. Porque está criando muito pau, iwirã, ja'i ('castanha'). Ani criou o pau e criou o mato. Ja'i, kopi'i ('cupuaçu'), atfa 'i ('açaí'), cuia cria também. Cria para ficar na casa, ficar bonito".

Em outro momento, ainda buscando aprofundar os entendimentos sobre a formação das florestas, em conversa com Tatua ru, seu filho, Araparawi, responsável pela tradução, coloca a seguinte formulação: - "Quem plantou (uti) a floresta?". Tatuaru então responde que antigamente akoti-uhu ('cotia grande') plantou todas as árvores, plantou a floresta todinha, ja'i ('castanheira'), ñamo'i ('sumaumeira'). Akoti huwiha plantou ja' $i^{25}$. Quando eu perguntei quem plantou urucum, planta de quintal, Tatuaru respondeu que foi Pï̈̈̈. Relatou ainda que Pï̈̈̈ plantou karã (“cará”), awati ("milho”), madia ("mandioca"), kurawã ("tipo de bromélia"). Araparawi, ao traduzir a fala de Tatuaru, diz: "Pï̈ï plantou a planta pra gente comer. Foi ele quem plantou tudinho milho. Pï̈p̈̈ é bïde ('gente'), ele é gente. Akoti huwiha ('cotia grande') era bïde. Ñã-Maï ${ }^{26}$ fez ele virar akoti ('cotia') pequena. Foi Deus que transformou ela nessa cotiazinha. O que plantou (akoti uhu — 'cotia grande') virou cotia pequena. Esse Deus que transformou a cotia era muito poderoso. É a mesma cotia que essa pequena que ficou aqui. Agora a akoti pequena também planta. A akoti pequena não é bïde, agora é pra comer mesmo. Todo passarinho era gente; kararoho ('paca'), era tudo gente. Atodi ('um tipo de pássaro') não era gente, foi Deus que fez. Tajahu ('queixada') era do Deus mesmo, ele

\footnotetext{
${ }^{22}$ Essa banana-brava era o alimento dos deuses antes de os Araweté conhecerem o milho. O vegetal que denominam como banana-brava não era plantado por Mai, ele se reproduzia sozinho nas matas. Aliás, ainda se reproduz nas matas, conforme me mostraram quando estávamos caçando jabotis. Mai não "conheciam o fogo nem as plantas cultivadas, que lhes foram revelados por humanos [...]. Desconhecendo o milho, comiam o fruto da bananeira-brava, que cresce espontaneamente na mata e é dita, ainda hoje, ser "coisa plantada por Mái" (Viveiros de Castro 1986:220).

${ }^{23}$ Deve ficar claro que o termo 'plantas', nesse contexto, não foi empregado no sentido de plantas cultivadas.

${ }^{24}$ Em outra seção abordarei essa categoria de ser que compõe o cosmos, mora nas florestas e marca uma oposição fundamente com Mai.

${ }^{25}$ Quando fui checar meu entendimento sobre alguns pontos desta narrativa, outro filho de Tatua ru, Iwaneru, disse que a akoti huwiha - cotia grande havia plantado apenas a castanha.

26 "Ñ̃a-Mä̈, Onça-Divindade" ("é apenas seu nome", dizem os Araweté, não tem nada a ver com os jaguares (Viveiros de Castro 1986:238). Ñã-Mäi é um ser "tipo-Mái" que vive no patamar celeste. De acordo com Tatua ru, $\tilde{N} \tilde{a}-M a \underline{i}$ subiu para o patamar celeste após sua mãe ser devorada por uma onça.
} 
mandou para comer, não era bïde. Ele fica em gaiola. Só cateto era gente também. Até o beija-flor era gente. Tapii ('anta') também”.

Assim, a presença de espécies vegetais encontradas nas florestas na camada terrestre é atribuída pelos Araweté ao Mai que ao subirem ao céu "deixaram" coisas na terra e, entre elas, "todas as plantas" aqui encontradas, conforme destacado por Tiñarai du para a akoti-uhu ("cotia grande") que "plantou todas as árvores, plantou a floresta todinha", e ao Ani que "criou o pau e criou o mato". Ani, por sua vez, seria o responsável por cuidar de algumas árvores, como veremos adiante, no capítulo II.

Para a akoti-uhu ("cotia grande"), segundo os Araweté, foi atribuída a plantação de árvores que compõem as florestas, atividade exercida até os dias de hoje pelas cotias pequenas para algumas para espécies, como a castanheira, por exemplo. Por outro lado, Piïpï, um outro tipo de gente, foi o responsável por disponibilizar as plantas cultivadas. Se akoti-uhu ("cotia grande") e Piipi foram identificados como bïde, noção que indica "'ser humano', 'gente"' (Viveiros de Castro 1986:207). Entre os Araweté "[...] há objetos e plantas que são 'feitos' ou 'plantados' por bïde ; outros são feitos e plantados 'por Mại '"' (op.cit:210).

Por ora, vale apontar com relação à composição das florestas ${ }^{27}$, tratando-se especificamente dos vegetais, que várias são as suas condições e modalidades de constituição e adensamento. Os vegetais encontrados nas florestas foram "plantados", "abandonados" ou "criados" e assim foram sendo constituídas as matas por onde circulam os Araweté.

\section{$K a^{\prime} a$ iwe - na floresta}

Em princípio, será feita uma aproximação lexical limitada do termo $k a^{\prime} a$ empregado pelos Araweté para nomear o que denominamos como florestas. A compreensão semântica da terminologia $k a^{\prime} a$ iwe será tecida pela composição, como veremos ao longo deste trabalho, entre diversas conexões estabelecidas, cujas possibilidades de arranjos mantêm-se abertas diante da diversidade e natureza das relações que abarcam

\footnotetext{
${ }^{27}$ A partir desta seção tratarei das florestas encontradas no patamar terrestre.
} 
essa complexa categoria, sob pena de redução dos significados e entendimentos empreendidos pelos ameríndios.

Nas línguas tupi-guarani, um termo cognato com eventuais variantes qualificadoras, designa o domínio das florestas. A tradução de $k a^{\prime} a$ para floresta é feita com hesitação por Oliveira (2012), cujo material baseia-se em dados etnográficos produzidos entre os Wajãpi, a fim de não correr o risco de reduzir seu vasto uso. $K a^{\prime} a$ é indicado como um conceito de difícil tradução. "No dia a dia das relações com os não-índios, os Wajãpi ora transpõem $k a^{\prime} a$ como 'floresta', ora como 'ambiente', às vezes como 'biodiversidade', ou ainda como 'natureza'. Outros experimentos de tradução incluíram: lugar, cobertura vegetal ou paisagem. Na verdade, para os Wajãpi, $k a^{\prime} a$ não se limita à ideia de floresta, nem de vegetais silvestres [...] ' $k a$ 'a' é um conceito geral, uma categoria de pensamento wajãpi, que não corresponde a nenhum dos nossos conceitos." (Gallois 2011:75). Entre os Awá-Guajá, floresta, também traduzida como ka'á, "[...] é o seu lugar de vida." (Garcia 2010:34) e ka'ape - na mata (op.cit.:57). Por sua vez, Ka'apor - auto-designação de um grupo tupi-guarani hoje encontrado no norte do Maranhão -, significa footprints of the forest (Balée 1994a:16), que poderia ser traduzido literalmente como "pegadas da floresta".

Para os Araweté, os domínios das florestas são denominados, de forma genérica, $k a^{\prime} a$ iwe ("na floresta/na mata"). $K a$ 'a é um termo que indica mata e $i w e$ ou we é um locativo pontual que "flexiona o tema nominal de forma que este 'torna-se um lugar específico em que se está"' (Solano 2009:134). É recorrente designarem o termo ka'a iwe ou ka'a we ao se referirem às florestas. Usam também o termo $k a^{\prime} a$ iwe ou $k a^{\prime} a$ we para indicar que alguém foi caçar: "Ka'a we ure ha" - "Nós vamos caçar". O ato de caçar também é designado pela expressão " $u$-ata”, que também significa "andar" - "ku u-ha u'ata” "foi andar/caçar" -, ou pela palavra "juka" - "matar" - "a-juka ku he tajahu” - "eu cacei/matei queixada". Assim, apreende-se um trinômio - caçar, andar, matar - que é central na composição do entendimento araweté sobre florestas que envolve a produção da vida social. O fato é que não tratarei diretamente da caça - por questão de escopo e condições efetivas para a realização deste tipo de pesquisa -, atividade instigante e complexa que permeia o entendimento das relações que compõem o domínio das florestas. Não menos importante são os vínculos e conexões estabelecidas com e a partir de vegetais por estarem diretamente ligados à caça, aos rituais, à fabricação do corpo, à 
cosmologia, entre outros, mas eu diria que menos agentivo e, talvez por isso, menos explorado pela etnologia até o momento.

As etnografias Wajãpi, por exemplo, indicam que "[...] o recorte semântico do termo $k a ' a$ circunscreve, sobretudo, as plantas que ambientam e constituem esse domínio" (Oliveira 2012:13) que "[...] é essencialmente representado pelas árvores (yvyra) e palmeiras" (Gallois 1988:73), pistas estas que colaboram para reforçar a opção pelas relações estabelecidas a partir dos vegetais para desvendarmos este domínio.

É inerente ao domínio das florestas a permanente transformação, dinâmica visivelmente marcada pela conversão da roça em aldeia e da capoeira em mata. O léxico araweté marca esse movimento quando roça é designada pelo termo $k a$ (Viveiros de Castro 1986:153) ou pelo termo $k a^{\prime} a$ acrescido do sufixo pite, ka'apite ("roça") e ka'apite-we (“a roça") (Solano 2009:134,142); ou quando a capoeira - lugar de roça antiga com vegetação em crescimento - é designada por $k a^{\prime} a p e$, sendo que o sufixo pe indica existência retrospectiva (op.cit.:141). Tal dinâmica de transformação é experimentada ao longo do tempo, como quando andávamos na ka'ape - capoeira atrás da casa de Tatua ru - e Iwadma, esposa de seu filho, me disse que na época em que se mudaram para a aldeia Ta'akati $^{28}$ este local era a roça de Tatua ru e naquele momento, quando andávamos numa mata mais alta pelo caminho ("pe") de Tatua ru que nos levaria à roça plantada em local mais distante da casa em decorrência de sistema de rodízio de plantio de roça.

Aqui, apoio-me em Descola (2005), sem, no entanto, apostar em grandes divisores fixos, a partir de sua etnografia sobre prática e o simbolismo na ecologia dos Achuar equatorianos para desconstruir a visão clássica que opõe floresta à roça como uma dicotomia entre a natureza e a cultura, esferas masculina e feminina. A roça não representa para os Achuar a transformação cultural de uma porção do espaço natural. Nesta lógica do continuum cultural, a roça domesticada pelos homens é a realização temporária das virtualidades de uma natureza doméstica instaurada pelos heróis míticos criadores das plantas cultivadas e silvestres. A roça seria um universo de consanguinidade e, a floresta, um mundo de afinidades; ambas governadas por relações

\footnotetext{
${ }^{28}$ Mudaram-se para a aldeia Ta'akati em 2012 e esta caminhada ocorreu em 2014.
} 
sociais idênticas as que se têm em casa. A floresta é governada por relações de sociabilidade e é percebida como a grande plantação de Shakaim, espírito antropomorfo das plantas silvestres (Descola 1986; 1988). A ideia de que a natureza é o campo dos fenômenos que se realizam independente dos homens e das relações sociais instituídas pelas diversas categorias de seres é completamente estranha aos Achuar, podendo ter essa afirmação extrapolada para os ameríndios.

As dinâmicas de vida social e as sociocosmologias ameríndias revelam um campo mais fluido para a compreensão dos domínios das florestas. No caso dos Araweté, a ideia defendida por Viveiros de Castro (1986:188-189) relativa à intercambialidade dos valores dos eixos horizontais e verticais, marcada por distanciamentos e aproximações estabelecidas a partir de qualidades simbólicas, e à dificuldade em demarcar distinções entre as categorias de seres e de "[...] caracterizar de modo simples o espaço da "Natureza" na cosmologia" (op.cit.:223), reforça a posição de que os domínios das florestas, apesar de se configurarem por algumas marcas específicas, são compostos por cadeias que se conectam e se reconectam de formas circunstanciais e lógicas. Essas cadeias abarcam relações biológicas, geológicas, sociais, cosmológicas etc., que indicam uma profundidade que foge do escopo desta tese, cujo objetivo está em partir de algumas dessas associações empíricas a partir dos vegetais para compor, de forma mais estruturada, esta fluidez.

Os domínios das florestas nas etnografias ameríndias são caracterizados como, entre os Wajãpi, "[...] espaço 'povoado' [...] por uma diversidade infindável de seres [...]" (Cabral de Oliveira 2012:13) e "[...] um espaço frequentado diariamente pelos homens que o conhecem minuciosamente. É também nas florestas que os xamãs encontram as entidades que mais os ajudam em suas atividades de cura e/ou retaliação [...] a floresta é vista como um espaço que pode ser 'amansado' pelos homens" (Gallois 1988:73); como um local perigoso ${ }^{29}$ e do exercício da vida onde se pratica principalmente a caça; um espaço estratificado sendo cada nível habitado por seres particulares como animais, plantas e insetos que são classificados como "comedores" ou "comida" de acordo com o seu espaço vital, como entre os Makuna (Århem 1993); espaço de moradia de animais,

\footnotetext{
${ }^{29}$ Oliveira considera que para os Wajãpi a floresta é perigosa e hostil (2012:33). Por sua vez, alguns Araweté me disseram que, na mata, as cobras e as onças é que são perigosas. Sendo assim, surge a reflexão que seres encontrados nas florestas é que podem ser perigosos e não exatamente a floresta enquanto um domínio.
} 
vegetais e dos "bichos" yama, seres amedrontadores que aparecem na forma de animais não homogêneos, mas divididos em partes associadas "[...] às espécies animal e/ou vegetal que lá se encontram." (Maizza 2009:58); ou, como entre os Awá, cuja floresta é vivida e percebida como um local fresco e bonito, "[...] onde regozijam-se de prazer e alegria, e onde passam muitas horas do dia simplesmente deitados ou conversando [...]" (Garcia 2010:41). Lá, a vida social nas florestas ocorre em meio à fartura, com abundância de comida, especialmente nos acampamentos de caça, atividade fundamental para os Awá que indica um permanente desejo de estar nas matas, apesar do perigo que elas oferecem "[...] tanto pelos seres visíveis (onças e cobras, por exemplo), quanto por invisíveis (sobretudo os fantasmas ajy)" (op.cit.:58). Florestas, além de comportarem diversas categorias de seres, têm suas dinâmicas regidas por redes de relações como a "terra-floresta" dos Yanomami que "[...] é o lugar de uma complexa dinâmica de trocas, conflitos e transformações entre as diversas categorias de existentes que a povoam, sujeitos humanos e não humanos, visíveis e invisíveis.” (Bruce Albert 2003:46 apud Pardini 2012:212).

Florestas, para além de espaços geográficos ou domesticados, são sobretudo constituídas por experiências, qualidades sensíveis, aspectos sensoriais e relações lógicas que são difundidas por meio de ricas narrativas. Florestas, ao mesmo tempo que configuram domínios e histórias bem marcados, contam com dinâmicos sistemas de "apagamentos" que podem ser retratados pela fugacidade dos caminhos de caça, da roça e de acesso à cacimba ${ }^{30}$ que devem ser reforçados e redesenhados com frequência e marcam transformações recorrentes. Florestas se tornam perigosas, encantadoras, extenuantes, provedoras etc. dependendo da posição ou do estado que se encontra quem a percorre, da ação pretendida e das relações estabelecidas. Assim, florestas estão em permanente transformação e são constituídas pelas referências e experimentações que abarcam aspectos visíveis e invisíveis, tangíveis e intangíveis, fugazes, temporais, convencionais e lógicos.

\footnotetext{
${ }^{30}$ Entre os Araweté, as cacimbas são cavadas pelas mulheres e utilizadas preferencialmente pela família extensa que reside em uma aldeia. Neste caso, as cacimbas são abertas nos caminhos que levam a riachos e a locais alagados próximos às casas daquele grupo familiar. Em qualquer inclusão na mata onde ficarão alojados por algum tempo, como o local de uma derrubada de árvores para a criação de uma roça, ou um acampamento de caça, por exemplo, uma das primeiras atividades é a abertura de cacimbas para obtenção de água potável.
} 


\section{Instaurando descontinuidades}

Diferentes tipos de relações e os seus respectivos efeitos, como as diferentes práticas para a produção e reprodução da vida acionam e sinalizam descontinuidades nos diversos domínios que compõem o cosmos. Nesta seção apontarei os elementos e os tipos de relações, estabelecidas preferencialmente a partir dos vegetais, que acionam descontinuidades nos domínios das florestas, visando, portanto, escapar das noções prédefinidas e homogêneas.

O direcionamento, aqui, não é (re)construir os domínios das florestas a partir de perspectivas ameríndias, mas apresentar diferentes contextos de relações que não se configuram como totalizantes, estabelecidos a partir de observações em campo ou de narrativas etnográficas por meio de conexões e posições específicas. Vale dizer que as posições não são fixas, mas assumem pontos de vista dependentes de contextos de relações nos quais estão engendradas. Ao se colocarem como ente central em determinada rede, não deixam de ser parte de uma estrutura quando são considerados outros referenciais, e de participarem de outras redes em diferentes posições.

Considero válido assumir um referencial para a noção de relações seguindo um direcionamento de P. Descola, que contribui para a construção de campos de relações a partir do estabelecimento de séries que marcam descontinuidades. "But what we mean by 'relation' is not exactly what the British call 'social relations'. Relations for a structuralist are built as logical connections in a model which can account for the difference between specific sets of social relations in different societies." (1992:11).

Durante uma "caçada" de jabotis com os Araweté, um casal que eu acompanhava me mostrou que "o jaboti fica na floresta dele" ${ }^{31}$. Qual seria, então, a floresta do jaboti? Os Araweté são aficionados por carne e vísceras de jaboti, tema constante nas conversas, refeições e empreitadas araweté. De acordo com as observações dos Araweté e com os hábitos alimentares destes quelônios, conseguimos identificar que os jabotis são encontrados com frequência próximos às árvores que fornecem flores e frutos dos quais

\footnotetext{
${ }^{31}$ Perguntei aos Araweté se a expressão "floresta dele, de jaboti, de paca, de anta ..." poderia ser traduzida na língua araweté. Mas em nenhum momento fui apresentada a algum termo que correspondesse a esta expressão.
} 
se alimentam. Os jabotis, segundo os Araweté, gostam de ficar debaixo de paus secos e "moram" em buracos cavados no chão, nas proximidades destas árvores.

Essas conexões não são relacionadas apenas aos jabotis, mas a outros animais que se alimentam preferencialmente de vegetais e frutos como a anta, a paca, o veado e o jacu. Akaña ("cajá") é comido por jaboti, anta, paca e jacu, portanto akaña é considerada "floresta do jaboti, da anta, da paca e do jacu"; murerawi, também denominada bucha, é outra fruta que jaboti come e é considerada "floresta do jaboti"; ñapuka'i ("sapucaia") e flor de mata-mata, são a "floresta da paca"; ñapuka'i também é a "floresta de anta e veado". A presença destas árvores, inclusive, indica que os locais em seu entorno são reconhecidos como de circulação concentrada desses animais e onde podem ser encontrados com mais facilidade.

E a onça teria também a floresta dela? No caso da onça, não cabe dizer "a floresta da onça". Segundo os Araweté, ela fica na $k a^{\prime} a$ iwe, na mata, referência mais abrangente e externa ao domínio das florestas. Os Araweté dizem que "a onça come veado, jaboti, porco, cateto e não tem a floresta dela"; "onça não tem floresta porque anda atrás da gente". As onças mantêm com os homens uma relação de presa e predador. Além de ser um animal carnívoro, as onças não estabelecem interações diretas com determinadas árvores, especialmente as frutíferas, nem suportes fixos relacionados a lugares e a seres específicos.

A referência à "floresta dos jabotis", "das antas" etc., com os seus marcadores físicos, como árvores frutíferas e caminhos indicados, especialmente, por determinadas características que estão associadas ao modo de vida dos jabotis ou de outros animais (como o habitat e alimentos consumidos), confere descontinuidade ao domínio das florestas. Esses animais são referenciados pelos Araweté como "donos" (ñã) de certas "porções" da floresta, cuja diferenciação não é tão marcada por uma relação de dominação, controle ou propriedade, pois estão mais atreladas a conexões fugazes, embora previamente determinadas, e não somente por uma associação alimentar direta de certos animais com determinadas árvores, bem como aos locais onde gostam de circular. 
Os Araweté dizem, por exemplo, que "jaboti não tem dono, jaboti cria sozinho no mato, quem criou ele foi a floresta dele, a fruta dele que criou ele"; "taraik $\tilde{a}^{32}$ é a floresta do jaboti, não tem dono"; "jaboti não tem dono, todo mundo pode comer"; "murerawi criou no mato, não tem dono, jaboti é dono porque está comendo, não foi jaboti que plantou bucha". A relação alimentar estabelece um vínculo entre presa e predador que é identificado a um tipo de criação que está menos relacionada a uma ação intensa, como entre pais e filhos, que envolve o cuidar contínuo, a dedicação e um vínculo afetivo, mas não apenas a uma relação funcional de subsistência. As porções da floresta não são identificadas a todos os animais que se alimentam, principalmente, de vegetais e frutos; e, tampouco, a todos os vegetais e frutos que estes animais se alimentam. Não foi levantada uma lista extensa sobre este tipo de relação, mas o fator determinante neste caso é a recorrência dos tipos de associações estabelecidas quando é acionada esta forma de enunciação que remete antes a uma forma de proximidade. Essa dinâmica não indica uma relação de exclusividade em relação ao uso e apropriação do espaço por determinado ser, mas marca um domínio circunscrito e contextual que tem como ponto de referência espécies de árvores que operam como índices concretos em uma cadeia relacional.

Para os Jarawara, "porções" da floresta são caracterizadas por tipos de vegetações relacionadas a habitats dos animais, como o local situado entre a terra firme e a várzea, constituído por mato cerrado, taboca e cipó, e habitado por onças e pelos macacosbarrigudos que moram em cima das árvores (Maizza 2009). Os Zo’é se referem a determinados lugares como koha, noção designada por Bindá como "[...] lugar de exercício de um jeito de ser/viver, o que era o mesmo que falar do lugar de relações sociais próprias a cada jeito de ser particular." (2001:80). Não há, portanto, um lugar definido enquanto materialidade. Cada ser associado a um domínio koha exerce nele uma vida social e torna único cada koha. Entre os Awá, a noção harakwá, central na socialidade deste grupo, é traduzida como "aquilo que eu conheço" (Garcia 2010:67). No entanto, Garcia (2010) distingue o harakwá Awá do koha Zo’é enfatizando sistemas de ação em detrimento aos modos de ser e estado de vida. Harakwá são exclusivos a uma família e/ou grupo local. Alguns animais e outros seres são definidos pelas diversas formas de interação que nele se processam. Tal como ocorre aos humanos, para esses

\footnotetext{
${ }^{32}$ Espécie de fruta.
} 
animais, a escolha de um harakwá, passa pela combinação de hábitos alimentares (o que se come e o que não se come), subsistência, a qualidades do habitat (como conforto, segurança, entre outras) e é marcada pela ideia de gostar.

"Florestas dos jabotis, antas, veados...", koha e harakwá colaboram para indicar descontinuidades nos domínios das florestas, o que não significa dizer que são noções correlatas sendo que não são comparáveis. O fato é que descontinuidades são marcadas a partir de sujeitos de referências conectados a outros seres. Os Araweté, Awá, Zo'e, entre outros, percebem e instauram descontinuidades nos domínios das florestas a partir de posições, cadeias relacionais vinculadas a sistemas de ação e qualidades sensíveis percebidas a partir de lógicas compartilhadas.

\section{Nem tudo é plantado: posições identificadas a partir dos vegetais}

Aradjma, moradora da aldeia Arajity, disse, sem fornecer maiores explicações, que " $k a$ 'a é outro de ka'apite; ka'apite é diferente". Diversos fatores contribuem para compor esta diferença, mas aqui me atentei apenas aos vegetais. A relação floresta/roça pode ser marcada por estágios de sucessão dos vegetais, processo indicado não apenas pelo crescimento da vegetação, mas pela presença de diferentes seres, situação que remete, portanto, ao estabelecimento de relações específicas em cada um destes domínios.

Se as narrativas ameríndias indicam que os vegetais, sejam aqueles encontrados nas roças ou nas florestas, foram plantados ou "deixados" por alguém na camada terrestre, conforme exemplos Araweté, Wajãpi e Achuar, há plantas plantadas pelos homens, pelos animais ou outros seres, mas também existem aquelas que ninguém plantou, ao menos entre os Araweté. A polaridade delineada entre o plantado e o não plantado tem como referência, além de formas de classificações binárias (Lévi-Strauss 2005:120), a condição de agente em relação à "coisa" ou ao "ser" plantado, situação que envolve intencionalidade e esferas de negociações.

Embora os operadores plantado e não plantado possam, de imediato, serem associados à roça e à floresta, o fato é que devem ser analisados sob o ponto de vista de alguém, condição esta contextual, e não devem ser marcados apenas a partir de plantações dos 
humanos. "O ponto de vista implica certa concepção, segundo a qual só existe mundo para alguém [...] o que existe, existe para alguém. Não há realidade independentemente de um sujeito." (Lima 1996:31). Vale destacar, então, que o que existe para alguém é apenas parte do que existe para outrem.

Portanto, ao indicar aquilo que é plantado e aquele que plantou, condições que não devem ser percebidas como variáveis independentes ou em permanente estabilidade, mas observadas no exercício da relação, emergem posições onde menos importa a diferenciação substantiva entre os sujeitos - que não são definidos a priori, mas constituídos na relação. É a possibilidade de existência de pontos de vista e de e do estabelecimento de relações ${ }^{33}$ que exige maior atenção e implica, por sua vez, na própria extensão da socialidade. Vale dizer que as posições não são fixas, pois a pessoa carrega multiplicidades que reflete uma ambivalência posicional (Viveiros de Castro 2002b:377). Nesse sentido, vale a pena investir em duas questões: a) plantado por quem?; b) e, se realmente tudo é plantado.

Descola mostra que a distinção entre plantas domesticadas e plantas silvestres, ao menos entre os Achuar, está relacionada tanto ao lugar onde se encontram como ao investimento no trabalho agrícola. As plantas cultivadas na roça são classificadas como aramu - "o que é enterrado pelos humanos". As plantas semicultivadas quando fora do contexto da roça são consideradas silvestres mesmo estando enquadradas na categoria aramu (Descola 2005:225).

Para os Araweté, como dito anteriormente, as plantas cultivadas pelos humanos foram doadas a estes e aos deuses por Piipi, um "ex-verdadeiro humano" e "senhor das coisas boas" e remetem, segundo Viveiros de Castro, "integralmente ao domínio do humano" (1986:228). As plantas cultivadas na roça, como awatfi ("milho"), madia ("mandioca"), karã ("cará") ${ }^{34}$, e as de quintal, como iriku ("urucum"), ingá, nani ("abacaxi") e mumu

\footnotetext{
${ }^{33}$ Viveiros de Castro, inspirado em Deleuze e Guattari (1991) insiste no princípio que constitui o estabelecimento de relações não a partir de um sujeito particular e instituído a priori, mas da possibilidade da existência "da figura de Outrem" e, portanto do ponto de vista como condição que gera a criação de mundos possíveis e, por fim, acomoda sujeitos concretos nas relações em jogo (2002a:118).

${ }^{34}$ Majato disse que os homens ou mulheres podem plantar mandioca; com relação ao milho, os homens cavam o buraco e as mulheres ficam responsáveis pelo plantio. Majato e Kunikuxã, nora e filha respectivamente, plantaram a roça de Tatua ru. Dizem que homens não servem para plantar e que é uma atividade preferencialmente feminina. As formas de plantio e a divisão do trabalho envolvida nesta atividade não foram temas de pesquisa em campo.
} 
("mamão"), plantadas principalmente pelas mulheres, pertencem àqueles que as plantaram e são responsáveis por seus cuidados. “Outras árvores e espécies vegetais da mata são associadas a certos espíritos seus "donos", que as plantam como fazemos com o milho: o açaí, o tucum, a cuieira, etc. [...] E há, por fim, algumas espécies de árvores que são Maï demï-neñã we, deixadas ou abandonadas (na terra) pelos deuses quando subiram com o firmamento: a castanheira, a kapo'iwã (uma árvore onde pousam os cotingídeos moneme e iriri $m e^{\prime} \underline{e}$, passarinhos "das divindades"), o payik $\underline{a}$, a árvore do paricá" (op.cit.:228-229).

Segundo os Araweté, o açaí e o cupuaçu foram plantados e são cuidados pelos Ani, um tipo de gente que habita a superfície terrestre, mora em ocos de castanheiras e de sapucaias e estabelece com os humanos uma relação de agressão, como veremos adiante. Essas espécies plantadas pelos Ani não devem ficar próximas às aldeias a fim de se evitar perigos aos humanos. A planta em si não é perigosa. É permitido coletar os frutos sem aparentes "cuidados", mas deve-se evitar derrubar a árvore para o uso da madeira, por exemplo, porque Ani fica bravo e pode até matar aquele que executou a derrubada. Ani é dono de kopi’i ("cupuaçuzeiro"), como dizem os Araweté: "é dono do kopi' $i$, porque foi ele quem plantou, é dele". O mesmo entendimento vale para os açaizeiros: "Ani é o dono do açaí, ele planta o açaí e por isso é o dono dele". O distanciamento, portanto, deve ser com os Ani que tem relação direta com certas árvores, seja como morada ou como cultivador. Os Araweté também dizem "[...] que os $\tilde{A} \tilde{n} \underline{i}$ e seu grupo têm grandes plantações de mandioca." (Viveiros de Castro 1986:245).

Alguns Araweté indicaram que a castanheira é plantada pela cotia: "a cotia cria castanha, gosta de comer". Tadi nu, morador de Arajity, derrubou uma castanheira para fazer caibro da sua casa. Em seu entendimento, a castanheira não é casa de Ani; cotia é a dona da castanheira, pois é a responsável por seu plantio: "quando cotia muda, leva castanha para plantar. Não pode ficar bravo quando cotia pega castanha, porque ela pega para plantar". Dizem também que há aves, por exemplo, que "não trabalham, não plantam nada e roubam a comida" dos Araweté, como é o caso de periquitos que invadem suas roças de milho.

Por outro lado, quando os Araweté fazem uma associação entre alguns animais e árvores, ligando-a às "florestas do jaboti, anta, paca etc.", não há, ao menos nas relações 
elencadas, uma ação de plantio por parte dos animais: murerawi é "floresta do jaboti", mas "não foi jaboti que plantou"; iwiriti poti ("flor de iwiriti") é "'floresta da paca', só paca come, não tem dono, não foi paca que plantou, nasceu sozinho".

Há, assim, árvores, e outros vegetais encontrados no domínio da floresta que foram deixados ou abandonados na plataforma terrestre pelos Mai e são identificados a uma categoria que os Araweté enfatizaram muito em campo, sobre as coisas que "nasceram sozinhas", "que são criadas no mato", "que simplesmente existem", "que não foram plantadas por ninguém". Quando fui buscar água com dois jovens em um igarapé usado pela família de Tatua ru, na aldeia Ta'akati, havia uma ñamo'i ("sumaúma"). Ao indagar quem havia plantado, disseram-me "ela mesma". Então, me mostraram uma muda de árvore pequena indicando a forma como ela se reproduz.

Em conversa com Tiñarai du percebe-se que há uma diferença em relação à criação das plantas cultivadas na roça pelos humanos. Ele, então, disse: "Pï̈pï deu milho, batata, mandioca, cará, mamão, pipoca (tipo de milho), tudo. Cotia plantou ja'i ("castanheira"), não foi Piïpï. Cotia está criando, está gostando de castanha para comer e já que ela plantou, a gente deixa pra ela comer. Quem é dona fica com um pedaço. Tira um pedaço para a cotia e índio pega outro. Cotia planta arahu (fruta que chamam de 'frutão')". Ao indagar se Pï̈pi deu nata'i ("pé de babaçu"), Tiñarai du nega prontamente e diz que "nasceu na terra, sozinho, criado no mato. Bacaba é a cotia que planta. Tem no Mai bacaba grande. É para comer cedo, no café".

Os Araweté usam o termo iti mire (iti-plantar / mire-nominalizar passivo) para coisas plantadas pelos homens, como o ingá, nos quintais, awatfi ("milho") e madia ("mandioca"), e o termo iti miri in para coisas não plantadas pelos humanos, como ja'i ("castanheira"), ou aquelas que "simplesmente foram deixadas", como nata'i ("pé de babaçu"). Esses termos e seus respectivos usos reforçam a constatação da polaridade entre aquilo que foi "plantado" e "aquilo que foi deixado", que "simplesmente existe" e "que se cria sozinho" no que se refere aos vegetais. Então, entre os Araweté nem tudo é plantado por alguém.

Uma atividade, em princípio, tão marcada pela condição humana coloca aparentemente em um mesmo plano predadores e presas (Araweté e cotia) e inimigos (Araweté e Ani), 
situação que pode aproximar esses seres pela ação de plantar/ criar / cuidar e pela posição de agentes, mas que não elimina as diferenças marcadas pela intensidade e intencionalidade da ação e pela forma de consumo dos alimentos. Se para os humanos, aquilo que é plantado e intensivamente cuidado é pilado, assado, fermentado ou cozido, não necessariamente para a cotia, por exemplo, aquilo que é plantado é cuidado e também deve ser preparado para ser consumido, conjectura que se não exclui essa possibilidade, não a torna imprescindível. De certa forma, a agricultura se completa na culinária o que pode ser observado quando Lévi-Strauss, ao analisar as narrativas míticas da vida breve, mostra-nos que "[...] a limpeza do terreno para a agricultura obriga o homem a queimar a madeira viva, a fim de obter as plantas cultivadas que ele se permitirá cozinhar apenas num fogo de madeira morta." (1991:151).

A prática agrícola também instaura a presença do agente no domínio plantado. As plantações "fazem perceber", evidenciam seu plantador e atraem os seres que possuem qualquer tipo de relação com determinado vegetal, como aqueles que dele se alimentam. Neste sentido, o tipo de relação e a forma de interação dos diferentes seres e domínios, tendo como referência os elementos vegetais, organizam e evidenciam posições reais e potenciais em jogo, mas não as cristalizam.

O marcador plantado e não plantado é, então, menos vinculado a distinção entre domínios de roças e florestas. Ficam evidenciadas características e posições que determinam descontinuidades nos domínios das florestas, a partir de contextos de enunciação e da execução das ações. A partir dos marcadores plantado e não plantado e pelas formas como se consome o alimento, é possível decompor o domínio das florestas e evidenciar séries de relações que revelam instâncias operadas pelas posições e pelos contextos de relações informados por esquemas de significação e ação.

\section{Caminhos e cursos d'água como marcadores}

Os caminhos traçados pelas humanos e outros tipos de gente indicam como movimentam-se pelos territórios, além de propiciarem a conexão, a comunicação e de marcarem experiências pessoais permeadas de memórias e de sentidos. Os caminhos 
abertos nas matas ${ }^{35}$, muitas vezes frequentadas cotidianamente, têm um caráter mais fluido e necessitam de manutenção permanente ${ }^{36}$. Os cursos d'água, por sua vez, além de serem habitações de seres do cosmos, operam como marcadores permanentes, em geral, e são fundamentais para a localização nas florestas. "Como defende Rival para os Huaorani do Equador, cujo 'Território' não pode ser visto como um espaço demarcado com limites definidos em todos os seus lados, ele é antes uma rede de caminhos utilizada pelas pessoas quando 'andam pela floresta' (Rival $2002^{37}$ apud Garcia 2012:48).

Abordar florestas como múltiplas redes de caminhos implica em lidar com a impermanência destes últimos e estabelecer um vínculo direto dos caminhos nas matas com aqueles que os criam e que por eles circulam. Ingold, pautado em alguns exemplos etnográficos, como situações observadas entre os Inuit, no Ártico, os Foi, de PapuaNova Guiné, os Orochon, na Rússia, entre outros, diferencia trilhas de rotas. As trilhas são definidas por movimentos que remetem a malhas de linhas sobre uma extensão cujos percursos engajados e atentos à textura de seu entorno constituem, afetam e marcam a própria jornada da vida em um caminho aberto a novas descobertas e possibilidades. As rotas, por sua vez, estariam limitadas a ligar pontos como uma travessia, enfim, como um transporte que leva de um ponto a outro. Estes movimentos são denominados, respectivamente, como wayfaring e transport. No caso dos caminhos na mata, estamos tratando de wayfaring que está mais relacionado a modos de ser, estar e constituir mundos e seres do que o transporte de um lugar a outro (2007:76-84). "The traveller and his line are, in this case, one and the same" (2007:76).

Nem sempre os caminhos são perceptíveis para quem não tem familiaridade com os códigos de determinados lugares, pois não se configuram como trilhas firmemente delineadas e limpas, mas por marcas extremamente tênues que imprimem suaves

\footnotetext{
35 Os caminhos permeiam todos os espaços do cosmos ameríndio, mas nesta seção tratarei, especificamente, dos caminhos abertos nas matas.

${ }^{36}$ Entre os Jarawara, como demonstra Maizza, "[...] os indivíduos das diferentes aldeias conhecem com grande precisão apenas a área próxima de suas habitações, que é a que utilizam no dia a dia" (2009:37). Diante desta constatação e da dinâmica de circulação dos Araweté pelas florestas, é claro que há uma maior proximidade e familiaridade para andar nas matas nas áreas próximas às aldeias onde residem ou em áreas onde caçam regularmente. No entanto, conforme explicado por Hawutire, cacique da aldeia Ta'akati, eles desenvolveram uma habilidade para andar nas florestas e assim podem andar em quaisquer florestas que necessariamente não irão se desorientarem.

${ }^{37}$ RIVAL, L. Trekking Through History - the Huaorani of Amazonian Ecuador. New York: Columbia University Press. 2002.
} 
indícios nas matas. O próprio caminhar (uatã - "andar") - e golpes de terçado em galhos e arbustos abrem caminhos nas matas. Como aponta Garcia, "não são somente pegadas que determinam uma trilha (hapé - "meu caminho"), já que povos como os Awá deixam poucos vestígios em uma paisagem. Galhos quebrados, folhas remexidas e marcações nas árvores são postos o todo tempo para que pessoas que estejam para trás saibam a direção correta a ser tomada, e não se percam nestas trilhas sutis, invisíveis aos olhos de um estrangeiro." (2010:57).

Entre os Araweté, sendo que cada família conjugal possui ao menos uma roça, cada família também "possui" caminhos ${ }^{38}(p e)^{39}$ que traçam percursos especialmente nas bordas das florestas uma vez que as aldeias estão localizadas nas margens do rio Xingu e do igarapé Ipixuna e as roças, em geral, em áreas mais distantes das margens dos rios. Nesses casos, não se trata de um conceito de propriedade, mas remete à própria "fabricação" de percursos que gera uma apropriação temporária por meio de uma capacidade criativa e transformadora decorrente de sua ação. Cabe àquele que abriu/amansou trechos ou porções das florestas a prerrogativa de certo tipo de domínio desses locais em relação aos demais habitantes da aldeia - ou mesmo em relação aos habitantes das demais aldeias, o que é raro, pois circulam cotidianamente em áreas próximas às aldeias onde residem e, portanto, não investem em criar roças ou caminhos em áreas muito distantes de sua aldeia.

A discussão sobre formas de apropriação e de propriedade é travada por Maizza em sua etnografia sobre os Jarawara, que ressalta que este tema permeia os grupos da família linguística Arawá (Maizza 2009:224-225). Os Jarawara aplicam a noção de propriedade para árvores frutíferas e alguns lugares ou coisas que as pessoas fabricam, ganham ou compram. "Entre os Jarawara, a noção de propriedade está também relacionada ao

\footnotetext{
${ }^{38}$ Entre os Araweté e outros ameríndios, há caminhos visíveis apenas aos xamãs, que ligam as diversas camadas e os conectam a outros seres do cosmos. Nesse caso dos Araweté há uma via principal denominada kirepe e são usadas por deuses e almas divinizadas em banquetes rituais e para descer na terra. São caminhos largos e perfumados (Viveiros de Castro 1986:191). Tatuawi, cacique da aldeia Djuruanti, disse-me que o mapuku - arco-íris (decompondo-se mapuku temos ma-cobra e puku-comprido, cf. Solano 2009:327) é o responsável por vigiar aqueles que passam pelo caminho que leva ao céu a fim de não permitir que seres indesejáveis transitem por ali. Também ouvi um relato de que o mapuku é o caminho que conduz "os mortos" ao céu. Para os Wajãpi, tupãsã são como finos fios invisíveis que ligam os xamãs aos seus mestres e os donos aos xerimbabos (Gallois 1988:189-190), sendo prerrogativa dos xamãs confeccionar novos tupãsã. Nesta seção, não tratarei deste tipo de caminho, mas tão somente daqueles abertos na floresta, como informado anteriormente.

${ }^{39}$ Conforme Solano, repe - significa 'caminho nosso' e hepe - 'caminho dele' (2009:105).
} 
conceito de troca, ou manakone. Todo trabalho deve ser reconhecido e retribuído de alguma forma; o mais importante não é o valor relativo das mercadorias ou das atividades, mas sim o ato de retribuir." (op cit.:225). Dessa forma, o investimento em atividades que propiciem a transformação de algum lugar ou coisa gera essa espécie de domínio, ou, minimamente, uma associação e relação de pertencimento que marca proximidade e certo tipo de controle, tema que será discutido adiante na seção sobre os donos. Dentre os Araweté, é estreitada a relação de proximidade entre um espaço onde houve investimento de trabalho por parte de uma família, o que produziu algum tipo de transformação, situação que indica o domínio sobre o lugar ou coisa transformada. No entanto, diferentemente dos Jarawara que atribuem o nome da(s) pessoa(s) ao caminho produzido pelo esforço delas (Maizza 2009:31), não observei entre os Araweté esse tipo de relação no que diz respeito aos caminhos abertos na mata. O fato é que parentes próximos e distantes ${ }^{40}$ podem circular por todo o território, mas não podem usufruir de coisas e bens dispostos nos caminhos dos outros.

Os caminhos que levam à roça, à cacimba e a locais de coleta de talos de babaçu - pina iwe, sendo pina a palha -, material usado na confecção de suportes onde as mulheres tecem suas saias (tupã $i^{41}$ ), são mais associados às mulheres e estão mais próximos das casas, mas, em geral, são os homens os responsáveis pela abertura dos trechos. Nesses casos, quando se referem aos caminhos, é mais provável que indiquem o lugar de destino, como a cacimba ou a roça de Munemei hi - velha senhora que reside na aldeia Ta'akati -, sem atribuírem uma denominação específica ao caminho em si. Os caminhos próximos à aldeia, especialmente aqueles que levam à cacimba, são limpos periodicamente por aqueles que fizeram a sua abertura para evitar que mulheres e crianças se machuquem em espinhos, por exemplo, além de afastar perigos eminentes como o aparecimento de cobras.

Hawoti, morador da aldeia Ta'akati e recém-casado com Kunipoti, disse-me que tem dois caminhos para caçar, sendo um deles uma trilha na ilha situada em frente à aldeia. Relatou que Kunipoti tem caminho para a roça de milho e para coletar lenha e talo de

\footnotetext{
40 Termos diretamente relacionados à noção de "[...] parentes 'próximos' ou 'verdadeiros' e parentes 'distantes' ou 'classificatórios"' discutidos por Viveiros de Castro em relação aos sistemas de parentesco amazônicos (1993:165).

${ }^{41}$ Uma atividade diária das mulheres araweté é a confecção desta saia em tear de talo de babaçu. As mulheres araweté, obrigatoriamente após a puberdade, usam uma saia feita de algodão tingido de urucum. Hoje muitas compram ou ganham uma linha vermelha que usam para a confecção da saia.
} 
babaçu para fazer a saia. A maioria das mulheres adultas e casadas possuem caminhos. $\mathrm{Na}$ aldeia Ta'akati, por exemplo, Jarama hi, separada e mãe de dois filhos, possui caminho para pegar talo de babaçu; Majato, casada há poucos anos, não possui caminho, portanto utiliza o caminho de seu pai; Munemei hi, uma velha senhora viúva mãe de diversos filhos, possui caminho para a roça de milho, de mandioca e para pegar talo de babaçu. Aos homens estão associados os caminhos de caça ${ }^{42}$ e coleta na mata e caminhos que levam a locais de corte de lenha para a produção de fogo. Kuruama hi, moradora da aldeia Djuruanti, disse que cada família tem um ou mais lugares para caçar jaboti e que há um conhecimento tácito de todos o que não é impeditivo de circularem por estas áreas, as quais não são denominadas de maneira específica.

A presença de açaizais - atfa'i ti, sendo $t i$ "coletivizador" -, bacabais e castanhais - ja'i $t i$-, produtos encontrados nas matas e que são apreciados e coletados pelos Araweté, também determina o traçado de caminhos. Majato ru disse que "escolhe fazer o caminho onde tem bastante bacaba e castanha". Embora estas palmeiras e árvores não tenham sido plantadas pelos Araweté, aquelas que se encontram no caminho de determinada família, não por acaso, são reconhecidas, de certo modo, como pertencendo a esta família pelo fato de ela ter tido o trabalho de traçar e limpar o caminho que leva a estas árvores frutíferas. Desta forma, cada família tem a prerrogativa de coleta de frutos das árvores encontradas em seu próprio caminho em época de frutificação.

Majato ru, novo pajé da aldeia Ta'akati, disse que "cada família tem um caminho onde pegam frutas e castanha, e nenhuma família pode pegar frutas e jaboti no caminho da outra". Majato ru relatou ainda que possui três caminhos. Um caminho leva à roça e os outros dois, em relação à aldeia, estão localizados à jusante e à montante, respectivamente, com entrada pelo rio Xingu, e apresentam abundância de castanha, açaí e bacaba. Karapi ru, seu cunhado que é casado e pai de três filhos pequenos, também possui um caminho com fartura de castanha, açaí e bacaba. Karapi ru relatou que para os outros moradores da aldeia coletarem em seu caminho, ou seja, aqueles que não são os seus consanguíneos ou não pertencem ao seu grupo doméstico, "o dono, tenetãmõ, tem que ir na frente". Tenetãmõ é uma noção que expressa liderança e indica

\footnotetext{
${ }^{42}$ Com essa separação a intenção não é fixar uma divisão do trabalho, além de não dar margem a uma fluidez na associação de caminhos aos gêneros. Indico apenas uma forma mais recorrente entre os Araweté.
} 
aquele que segue à frente, aquele que começa, cuja iniciativa está sempre presente em qualquer empreendimento coletivo araweté e que dela depende uma série de atividades que envolvem mais de uma família conjugal, como uma "caçada" de jaboti, a derrubada de uma área de mata, atividades de coleta e coletivas ocorridas na mata, entre outras. "O líder Araweté, assim, é o que começa, não o que ordena: o que segue à frente, não o que fica no meio" e os demais o seguem por "contágio", sendo esta a forma da "ação econômica Araweté" (Viveiros de Castro 1986:302) ${ }^{43}$. Karapu ru foi com sua esposa e filhos coletar castanha - $n i$ ti, sendo $n i$ a própria castanha - em seu caminho.

Quando eu estava na aldeia Djuruanti, em outubro de 2012, acompanhei um grupo de mulheres e crianças na atividade de pegar lenha para fazer fogo no caminho de Kunipaia ru, um dos pajés araweté, situado nas franjas da floresta, do outro lado do rio, na margem oposta à aldeia. Esta é hoje uma área de capoeira, sendo antigamente roça de Kunipaia ru. O dia foi dedicado a esta atividade. Limpar a área - no caso, através de fogo e de breve roçar - e cortar as árvores são atividades que cabem, como já dito, ao dono do caminho. Somente parentes consanguíneos, afins e classificatórios ${ }^{44}$ coresidentes, estes últimos quando convidados pelos parentes consanguíneos dos "donos" dos caminhos, têm a prerrogativa da coleta nas áreas delineadas. Dificilmente convidarão uma pessoa considerada tiwã ("não parente") para coletar e carregar lenha (ihat $j$ i). De preferência, serão agregados apenas os parentes "próximos" dos donos dos caminhos nesta atividade. O corte final em toras, das madeiras já mortas, e o carregamento dos troncos para a aldeia cabe às mulheres. As mulheres que têm filhos e cônjuge organizam seu próprio monte de lenha visando abastecer sua residência. As crianças são presença constante junto às mães, ora ajudando a carregar a lenha - cujo volume é adequado ao tamanho de cada criança -, ora chorando, ora brincando, ora mamando ou mesmo fartando-se com algum produto encontrado nas imediações.

Para a caça de jabotis que, em geral, é organizada pela demanda de um pajé (como veremos no capítulo III) ela pode ocorrer em locais frequentados por cada família ou em locais onde não costumam andar, quando traçam caminhos fortuitos visando atingir as

\footnotetext{
43 Para aprofundar o entendimento sobre a noção tenetãmõ, que envolve aspectos de liderança e de movimentos coletivos empreendidos pelos Araweté, ver Viveiros de Castro (1986:300-320).

${ }^{44}$ Viveiros de Castro apresenta dois pares conceituais para indicar o universo do parentesco Araweté: "[...] di/amite, lit. "outro igual"/"outro diferente", e sua especificação típica ani/tiwã, "parente", (i,e.irmão) /"não parente" (i.e. primo cruzado)" (1986:365).
} 
árvores que denominam como "floresta dos jabotis", conforme indicado anteriormente. "Olha - het $\{a$ - longe o pé de murerawi (árvores que produz fruto que jaboti gosta), faz caminho e vai atrás pra pegar o jaboti", assim me disse um Araweté. Ao avistarem as árvores que produzem frutos que servem de alimento aos jabotis, traçam uma rota e criam o caminho abrindo fugaz e superficialmente a trilha de passagem com terçado. A intenção não é tanto limpar a trilha, mas evitar perigos como animais peçonhentos ou mesmo machucar-se com galhos e vegetais urticantes. Em geral, cada família frequenta um ou mais lugares para pegar jaboti; todos sabem qual porção da floresta é área de circulação de determinada família e, assim, evitam andar pelas áreas de outras famílias. Em caças coletivas de jaboti, por exemplo, as famílias andam juntas até determinado ponto, quando, então, se dispersam por caminhos mapeados e de uso habitual de cada família, ao menos em locais que costumam caçar.

Os caminhos de caça ${ }^{45}$ podem ser previamente produzidos por uma família, indicando uma área de circulação recorrente, situação que não restringe, conforme enunciado, o deslocamento de outros membros do grupo naquela área. Nesse caso, os caminhos serão produzidos levando-se em conta hábitos e áreas de locomoção dos animais a serem caçados. Na mata, cada homem tem o seu caminho. Pode, muitas vezes, um grupo de homens sair junto para caçar, mas em algum momento, de acordo com o tipo de caçada planejada, dispersar-se por trilhas separadas. Ao final da caçada, reúnem-se novamente. Em outra situação, os caminhos podem ser abertos em decorrência de uma oportunidade imediata de caça, como quando avistam um bando de queixadas ou rastros de algum animal que gostam de consumir. Assim, seguirão as trilhas abertas por esses animais e não um caminho previamente delineado. Vale dizer que nem todo lugar nas florestas por onde circulam de forma mais frequente é recortado por caminhos usuais ${ }^{46}$.

Para os Akuriyó no Suriname, floresta "[...] constituye una red de rutas y lugares de habitación de las diferentes sociedades animales. Estas rutas y lugares son sitios de contacto entre los grupos de la selva y los grupos animales y las rutas animales que están repartidas por especies diversas parecen, en el marco de la sociedad humana, estar tambieen repartidas...Las rutas y caminos que llevan a los principales lugares de

\footnotetext{
${ }^{45}$ Entre os Jarawara também é indicado os caminhos de caça (Maizza 2009:31).

${ }^{46}$ A limpeza dos caminhos com o terçado é intrínseca ao andar (uatã) na floresta. O terçado e a arma de fogo são artefatos indispensáveis em qualquer andança pela floresta.
} 
forraje son aparentemente dominados por sus usuarios y es en estas intersecciones donde los turaekae cazan [...]" (Jara 1990:83).

Assim, ao acompanhar os Araweté em caçada coletiva de jaboti, ora eles indicavam sementes de cajá que haviam sido comidas por paca, ora um estrondo entre os galhos indicava a presença de uma anta, ou o barulho de macacos anunciavam que estavam passando em certa direção. O rastro (tati pe ho) de um bando de queixadas e outros animais anunciavam que haviam passado por ali e também indicavam a proximidade dos animais, além de revelarem a direção seguida. Para caçar tajahu ("queixada"), cuja carne é muito apreciada pelos Araweté, eles seguem os rastros deixados na mata. Às vezes acontece do bando de porcos passar perto dos caçadores, podendo ser visto ou ter seu forte e fétido cheiro reconhecido pelos caçadores. Ao avistar as queixadas, os homens correm em direção a elas; e, posicionados, miram e atiram.

Tiñara du disse-me que não se perdem $^{47}$ no mato pois usam como referência os caminhos traçados na mata, que mesmo fortuitos são fundamentais para a localização, e os cursos d'água. Quando percebem que há alguém sumido, organizam-se para uma busca. Desorientam-se, muitas vezes, porque não fizeram o caminho, ou porque andaram muito longe e saíram do caminho traçado ${ }^{48}$. Quando os homens se perdem nas matas, dizem que se concentram para achar a trilha de volta. Hawutire disse que, para evitar essa situação, marcam pedras, árvores, da raiz à copa, e cursos d'água que encontram nos caminhos. Quando o sol muda de direção podem se desorientar, mas "se pensar, se acha novamente".

Segundo Ingold, descobrir-caminho ${ }^{49}$ consiste em mover-se de um lugar para outro a partir da habilidade de se situar a partir de jornadas já efetuadas, relatos de outros, além de considerar no movimento os elementos perceptivos de seu entorno e não

\footnotetext{
${ }^{47}$ Quando alguém se perde no mato os Araweté dizem: ikãñi - "ele se perdeu"; e quando perdem o caminho dizem: pe ikãñi - "ele perdeu o caminho". Esse termo é empregado em diferentes situações como quando, "por sua vez, usam-se vários eufemismos e torneios estilísticos para mencionar a morte propriamente dita [...] ikãñi, 'ele se perdeu' ou 'desapareceu' [...]" (Viveiros de Castro 1986:483).

48 Quando perdem o caminho, dizem que têm de procurar ("het $\left.\int a^{\prime \prime}\right)$, palavra traduzida por ver/olhar/enxergar e empregada, por exemplo, para a caça de jabotis.

${ }^{49} \mathrm{O}$ artigo "Jornada ao longo de um caminho de vida: mapas, descobridor-caminho e navegação" é uma tradução do Cap. 13 de The perception of the environment. Essays in livelihood, dwelling and skill, ambos indicados na bibliografia. O termo "descobrir-caminho" é a tradução considerada mais adequada para "wayfinding".
} 
simplesmente de considerar uma posição no espaço. "[...] os lugares não têm posições e sim histórias [...] os lugares existem não no espaço, mas, como nós, em uma matriz de movimento" (2005:76). Os caçadores ao se perderem, acionam os elementos disponíveis, reelaboram seus passos e são estas referências que colaboram para que reencontrem novamente o caminho, pois "[...] seguir uma trilha é também retraçar seus passos, ou os passos de seus ancestrais." (op cit.:103).

Entre os Wajãpi foram levantados diversos aspectos que provocam o desvio dos caminhos e, consequentemente, fazem com que os caçadores se percam na mata: encontrar-se em um estado denominado awyry, traduzido como "loucura", gerado pela ação de algum dono de seres ou coisas encontradas na mata; ou em um estado de confusão mental denominado ãkãmovai, que provoca falta de concentração em relação à orientação pelos marcadores espaciais; estar em um lugar muito distante perseguindo uma presa e distanciar-se demais do domínio dos humanos; vivenciar uma caçada malsucedida que provoca a braveza do dono da presa e pode gerar uma ação de vingança e um estado de confusão mental, bem como o fato de não ter transitado em certa região da mata (Cabral de Oliveira 2012:118-129). Essas situações provocam a vulnerabilidade e a perda das referências dos marcadores espaciais e perceptivos. Nesses casos, os caminhos e os cursos d'água atuam como referenciais importantes para o reconhecimento do percurso a ser retomado, além de outros elementos sensoriais observados no entorno.

Desta forma, os cursos d'água ( $i$ - "água") também operam como marcadores espaciais tanto por suas características físicas quanto pelas relações que engendram. Os Araweté atribuem nomes diversos a diferentes formações aquáticas. Um rio largo com um fluxo d'água maior é denominado parani, como o rio Xingu que também pode ser classificado como parani uhu ("rio grande"). No parani moram diversos peixes e a sucuri, que oferece perigo constante. Io ho ("rio pequeno") parece um igarapé - que é um curso d'água menor e corta a mata. Io ho pode ser morada de trairão, entre outros seres. Ipã é uma "grota que fica com lama embaixo, grota no mato onde pesca tamoatá" $^{50}$ e $z i z u$ (peixe pequeno muito apreciado). Ipã hu é um tipo lagoa grande onde

\footnotetext{
${ }^{50}$ Disseram-me que no período seco, quando os rios estão mais baixos pela falta de chuva, os peixes se concentram em poços e canais secos denominados ipã.
} 
mora jacaré, poraquê, cari, curimatã, traíra. Zizu juka é o poço onde pegam $z i z u^{51}$. Iriapa, área que alaga na época das chuvas, é formado pelas águas de rios maiores durante a época das cheias, apresenta uma vegetação densa, com muitos cipós, e é denominado igapó; atravessam-no para adentrarem na mata. Itapã é tipo uma grota com água, mas não apresenta fluxo d'água corrente como um igarapé. Itapã pode ser usado para pescar, navegar e tomar banho; depende do regime das águas do rio para manter-se cheio $^{52}$.

No verão, os Araweté organizam, aos domingos, passeios nas praias dos rios ${ }^{53}$ (parani) ou em lagos (ipã) para pescar, comer, banhar, estar junto e se divertir. Ao chegarem nesses acampamentos, acendem o fogo, atam as redes e se organizam espacialmente em núcleos familiares. As crianças e jovens, principalmente, dedicam-se à pescaria; as mulheres limpam os peixes que serão assados e/ou cozidos para o consumo.

Ao indagar se moradores desses cursos d'água têm donos, as respostas proferidas pelos Araweté eram: do iriapa, "açaí fica perto"; do ito, "ninguém mora"; io ho próximo à casa de Tatua ru, "ninguém mora, tem trairão"; itapã, "ninguém mora", "tem mitu ("mutum") e jacu".

Para os Wajãpi, o mundo aquático é controlado pelo "dono das águas" (y-jar) e "as águas terrestres são a morada de moju (anaconda aquática ou sucuriju), dona de todos os animais aquáticos consumidos pelos Waiãpi, como também de todos os animais que vivem ou se alimentam perto das águas" (Gallois 1988:71); os Awá, povos das cabeceiras dos rios, têm pouca relação com cursos d'água, não sendo locais de interesse e considerados mais como obstáculos a serem transpostos, do que um meio de locomoção; os rios e igarapés foram abertos, antigamente, por um jacaré, que possuía aparência humana e era comedor de humanos sendo alguns seres do rio feitos por Maíra, herói cultural responsável pela criação de diversos seres (Garcia 2010:41-44); entre os Jarawara, os diferentes cursos d’água são indicados como habitações de

\footnotetext{
${ }^{51}$ Os Araweté organizam saídas coletivas para a pesca deste peixe - zizu juka / matar zizu.

${ }^{52} \mathrm{O}$ mundo inferior, ou seja, o mundo das águas tem como senhor Iwikatihã que "[...] não é um selvagem, pois possui casas e roças no fundo dos rios, além de se apresentar elaboradamente ornamentado" (Viveiros de Castro 1986:218).

${ }_{53}$ As praias se formam conforme o regime de chuvas. Com a diminuição das chuvas, os rios baixam e formam as praias, locais muito apreciados para banhos.
} 
espécies de animais, de vegetais e de "bichos-cobra", seres amedrontadores que afugentam os homens (Maizza 2009:62).

Os cursos d'água operam como importantes marcadores no domínio das florestas como nas situações indicadas a seguir: Janaimã Wajãpi, ao estar perdido, encontra o rumo de sua aldeia após se deparar com um igarapé e a partir dele se orientar para chegar na aldeia (Cabral de Oliveira 2012:120); ou quando, entre os Araweté, durante uma caçada de jabotis, segue com uma família o curso de um igarapé, sendo este o caminho de ida e volta da empreitada; ou quando, novamente durante a caçada de jaboti com as famílias de Ta'akati, seguimos, a partir do rio Xingu, por um itapã ("grota d'água") repleto de árvores e cipós até o seu término, e acampamos nas proximidades de sua margem para podermos tomar banho e obter água para cozinhar

Cursos d'água são usados pelos Araweté como caminhos ("-pe") de entrada nas florestas; como referências para caminhadas pelas florestas; como locais onde buscam alimentos, apesar de apreciarem mais carne de caça aos animais aquáticos; e como locais onde buscam momentos de convivência e diversão.

Florestas podem ser traçadas como trilhas de caminhos e cursos d’água, uma dinâmica entre o que não é permanente e o permanente, repletos de significados, histórias e memórias, cheiros, sons e formas que são referenciados a sujeitos e ações.

\section{Ani, gente da floresta}

Os domínios das florestas para os Araweté, além de serem povoados por animais e vegetais, são habitados pelos Ani que moram em espaços ocos nas árvores, têm aparência antropomorfa, cheiro fétido e são perigosos para os humanos.

"Os $\tilde{A} \tilde{n} \underline{i}$ são espíritos da mata, ferozes, canibais, raptores de mulheres e assassinos de humanos. Moram no oco das árvores kapo'i; andam sem adornos, têm uma cantiga feia e uma catinga inequívoca (hawĩñã, cheiro de suor e sujeira corporal). Eles são assim o oposto dos Maï, deuses perfumados, decorados e senhores de belos cantos. Os $\tilde{A} \tilde{n} \underline{i}$ vagam pela mata, mas podem também penetrar nas aldeias à noite, quando são identificados pelos xamãs e mortos" (Viveiros de Castro 1986:215-216). O termo Ani 
designa uma variedade de espíritos da mata como Koropi e Yriparadi e são dotados de uma potência ou essência 'xamânica': ipeye hã" (op.cit.:206). Esta potência xamânica é atribuída ao chocalho de xamanismo denominado aray, instrumento musical e transcendental inseparável do xamã.

Em conversa com Japiwin, na aldeia Aradjyti, foi relatado que "Ani é gente como a gente, mas a gente não vê, só pajé que olha. Ele come a gente assado, flecha a gente, cheira (he tun) a gente e mata, é bicho que pega a gente". Quando eu perguntei se Ani come ja'i ("castanha"), ele negou categoricamente. Assim, percebe-se que Ani gosta de carne, não de vegetais.

Alguns enunciados retratam a percepção dos Araweté sobre os Ani: "Ani é igualzinho a gente, ele come a gente; pra ele, a gente é tajahu. Ani quer matar a gente, chama a gente de noite de tajahu", disse-me um dia Araparawi, jovem recém-casado morador da aldeia Ta'akati. "À noite é que tem Ani. Ani mata a gente para comer assado, debaixo da terra", relatou Majato, na aldeia Ta'akati. "Ani é perigoso, mata a gente; mora na terra, no mato; não mora no parani, pajé sabe, mora no buraco do pau, no pé de sapucaia e ja'i", assim falou Karama ru, no Ta'akati.

Ao andar na mata durante o dia e passar ao lado de ocos de árvores onde indicam ser a morada de $A n i$, não demonstram estar sob perigo ou sentir medo. Enquanto pegávamos lenha perto da aldeia Djuruanti, Kunipido, uma menina de cerca de 10 anos mostrou-me duas árvores grandes com aberturas em sua base e apontou estes orifícios como sendo a casa dos Ani. Em momento algum demonstrou ter medo, cuidado ou qualquer restrição ao passar ao lado dessas árvores que estavam no caminho e por onde carregavam a lenha até a beira do rio. A lenha era armazenada no local até que fosse levada à aldeia pelas mulheres que realizaram o corte e o transporte da madeira.

Os Ani circulam à noite nas aldeias para flechar e matar os humanos. Apenas o pajé tem a prerrogativa de matá-los. Durante o dia, ao andarem na mata ou em caminhos que levam à roça, por exemplo, preferem estar acompanhados para evitar serem flechados pelos Ani. Crianças, mulheres grávidas ou em couvade são mais vulneráveis por estarem 
abertas a contágios perigosos "[...] pela solda precária alma-corpo" (Viveiros de Castro 1986: 467 ${ }^{54}$, mas todos estão sujeitos às flechadas dos Ani.

Aradma hi, moradora da aldeia Aradjyti, contou que Ani flecha à noite na aldeia. Seu marido foi flechado durante a madrugada na pista de pouso, situada a cerca de 50 metros da aldeia; disse que a dor é muito forte e que recebem a flechada nas costas, perto do braço. Somente o pajé pode tirar a flecha mordendo o local atingido, momento em que sai muito sangue de sua boca. No caso do seu marido, a flechada do Ani não foi fatal. O seu sogro Tomoro, homem muito idoso, e o pajé morderam o marido dela para que ele se curasse.

Quando Ani aparece na aldeia durante a noite e o pajé e seu assistente não conseguem matá-lo, no dia seguinte o pajé orienta para que todos se pintem de urucum ${ }^{55}$, coloquem penas brancas de gavião na cabeça ${ }^{56}$ e recomenda que passam o dia na mata, pois tem Ani na aldeia e esta é uma situação perigosa.

Mai avisa o pajé que tem Ani na aldeia e no intuito de matá-lo, entoam os cantos xamânicos e balançam seu aray, instrumento xamânico fundamental no processo de comunicação com Mai. O pajé passa horas cantando e, juntamente com o responsável por matar os Ani, perseguem-nos. Quando localizam o Ani, entram em disputa. Enquanto o pajé canta durante a noite no pátio da aldeia, seu "assistente" profere pauladas com o objetivo de atingir os Ani que, conforme escutei em gravação, manifesta-se com uma voz grave e forte. Na aldeia Ta'akati é Madai ru quem é o responsável por matar os Ani. Há então uma luta entre o matador e Ani. Enquanto aquele profere pauladas e dá ordens ao $A n i$, este tenta se defender. No dia seguinte, percebem-se marcas profundas na terra, em alguns pontos da aldeia e todos apontam como sendo o local onde foram dadas pauladas no Ani.

\footnotetext{
${ }^{54}$ Tratarei da fabricação do corpo no capítulo III.

${ }^{55} \mathrm{O}$ urucum é emblema dos vivos e o jenipapo dos Mai. A pintura de urucum e a plumagem são usadas para afastar os seres que ameaçam os humanos.

${ }^{56}$ Essa plumagem afasta, segundo Viveiros de Castro, as onças que estão rondando a aldeia. "[...] esta decoração está associada a um bater de asas do kanoho rá ${ }^{\prime} o$ we, o 'espírito da harpia', que amedronta as onças" (1986:356 - nota 52). No caso do uso dessa plumagem após a passagem dos Ani pela aldeia, acredito que se trata de princípio correlato.
} 
Os Ani também atraem os espectros dos mortos. "O aspecto terrestre do morto - um espectro - é dito seguir com os $\tilde{A} \tilde{n} \underline{i}^{\prime \prime}$ (Viveiros de Castro 1986:217). A morte ocorre quando $i$, alma-princípio-vital, escapa do corpo, cujo sintoma é manifesto pela parada dos batimentos cardíacos e da respiração e "[...] decompõe a pessoa em três elementos: o cadáver, o espectro (ta-o we) terrestre, o espírito celeste [...]" (op.cit.:495). O espectro do morto, um ex-semelhante que fica na terra, ou mais precisamente, na mata, torna-se perigoso. Este é denominado ta-o we e é o duplo do cadáver que fica na terra pelo tempo de apodrecimento do corpo e apavora os vivos com a possibilidade de transformá-lo em "[...] corpo sem alma, um ex- $\underline{a}^{\prime} o^{\prime}$ (op.cit.:492) $)^{57}$. Uma vez, Karama ru mostrou-me uma imagem de uma sombra e a comparou ao ta-o we, que segundo Viveiros de Castro é uma "[...] sombra livre, projetada por um cadáver imóvel." (op.cit.:498). No período pós-morte, os Mai se fecham por estarem furiosos com os mortos e os Ani aparecem com veemência. Neste período ocorrem embates recorrentes entre xamãs e Ani. Assim, se a camada celeste é o lugar dos $M a i^{58}$ (humanos que se transformaram em deuses), as matas são os lugares dos Ani e dos espectros dos mortos.

A noção de "espírito" 59 não tem uma posição fixa e está inserida em uma dinâmica serial que abarca uma multiplicidade de afetos entre os ameríndios. "Um espírito, na Amazônia indígena, é menos assim uma coisa que uma imagem, menos uma espécie que uma experiência, menos um termo que uma relação, menos um objeto que um evento, menos uma figura representativa transcendente que um signo do fundo universal imanente [...]" (Viveiros de Castro 2006:326).

Entre os Tupi-Guarani, temos alguns cognatos da palavra araweté Ani que remetem a seres também habitantes das matas. Entre os Awá, os ajy são seres fétidos, pequenos, feios e com hábitos noturnos; moram em acampamentos nas matas abandonados pelos Awá, assumem a aparência de alguns pássaros, gambás e macacos-da-noite, têm a presença identificada por meio de assobios característicos, tornam a caçada uma atividade perigosa, por controlarem alguns animais, podendo fazer com que o caçador

\footnotetext{
${ }^{57}$ Para aprofundar esse tema, consultar Viveiros de Castro (1986:482-526).

${ }^{58}$ Há diversas espécies de Mai. Mai hete são os que devoram os humanos. A noção de Mai hete corresponde, portanto, a noção bide em sua concepção máxima. Mai são imortais. A noção Mai é processual (Viveiros de Castro 1986).

${ }^{59}$ Noção esta traduzida por "espírito" por não haver termo correspondente mais apropriado. Para os Araweté, segundo Viveiros de Castro, os espíritos terrestres estão distribuídos, além dos Ani, em donos do mel, Senhores das Queixadas - único espírito terrestre benigno, senhor dos peixes e dos rios, senhores de algumas espécies vegetais (Viveiros de Castro 1986:215-218).
} 
não tenha sucesso na caça, situação conhecida como panema. Os ajy assumem diversas posições, "[...] mesmo fantasmas para os humanos, eles mesmos se pensam como humanos, e ora enxergam os Awá como inimigos, ora como parentes próximos (harapihiara) [...]" (Garcia 2010:116). Como entre os Araweté, os ajy também estão associados aos espectros do morto, ha'aera que "[...] se transmuta em ajy" (op.cit.:110) e ameaçam aos humanos. Quando ficam expostos a este princípio mortal, podem adoecer e, no limite, morrer. Para os Wajãpi, ajã remete a uma categoria abrangente e ambivalente de seres que habitam a floresta; os ajã, noção tratada por Gallois (1988) como "efeito-espírito" genérico, estão envolvidos no sistema xamânico de agressões; os ajã são seres antropomorfos, fétidos, residem em buracos de pedras ou árvores e oferecem perigo aos humanos, pois desejam devorá-los (Gallois 1988 e Cabral de Oliveira 2012). Estes seres, apesar de antropomorfos, distinguem-se das imagens atribuídas aos humanos por não disporem dos "atributos de uma humanidade plena" (Cabral de Oliveira 2012:141) como cultivar roça, não comer alimentos crus, entre outros aspectos.

A intenção aqui não foi fazer um balanço comparativo e exaustivo das noções de "espíritos" mencionadas em diversos etnográficos, cognatas e semelhantes à categoria $A n i^{60}$, mas justamente caracterizar e elucidar as dinâmicas das relações dos seres que habitam as florestas e seus respectivos correlatos. Apesar de antropomorfos, em muitos casos, os Ani não carregam os atributos da humanidade e, portanto, não se assemelham aos humanos, conforme fica evidente nos comportamentos e formas como são percebidos. Ao se relacionarem com os humanos, instauram qualitativamente outras posições marcando assim relações diferenciais e reforçando aspectos da socialidade humana, não tão enfatizado por elementos substantivos, mas por modos de se relacionar, de perceber, de comer e de se apresentar. Os homens, ao se precaverem e tomarem ciência de que estão sob olhares de outrem ${ }^{61}$, circulam livremente pelas florestas sem a necessidade de empreenderem uma profunda transformação neste domínio. Esta situação demonstra que não há uma supremacia desses "espíritos", por vezes perigosos e canibais, sobre o domínio das florestas. Aos humanos cabe saber se comportar para se relacionar, se proteger e viver socialmente.

\footnotetext{
${ }^{60}$ Tarefa esta realizada por Oliveira (2012:129-143).

${ }^{61}$ Saber estar sob o olhar de outrem faz com que possam "ver aspectos do mundo tal como são vistos por aqueles que nos vê" (Lima 2005:217).
} 


\section{Quando florestas viram "acampamentos-aldeias"}

É impressionante a agilidade e a dinâmica dos Araweté quando, em grupos e com as famílias $^{62}$, decidem montar acampamentos provisórios para passarem dias ou horas nas matas, como em períodos de derrubada da mata para o plantio de roças ou em atividades de caça.

A escolha do local do acampamento é feita pelo tenetãmõ, que segue à frente, seja o dono da futura roça, ou o dono da festa do jaboti que originou a caçada coletiva, por exemplo. O tenetãmõ limpa e abre o caminho para as demais famílias passarem e também indica o momento de partida do acampamento.

A escolha do lugar em que irão se acomodar na mata é feita, em geral, pelo marido. Após definir o local, as mulheres tiram folhas, galhos e eventuais insetos, aracnídeos e répteis, além de cortar tocos de árvores dos locais onde serão armadas as redes ${ }^{63}$. Enquanto isso, os homens cortam, se necessário, troncos de árvores para limpar a área e montar a cobertura de palha a fim de protegê-los no caso de chuva. Dois esteios e um travessão cobertos por camadas de folhas inteiras e verdes de babaçu, se bem montados, resguardam as famílias de chuvas intensas ou intermitentes. Estas estruturas são denominadas tapiri. Derrubar e limpar são imperativos.

Limpar a área onde montarão um acampamento ou mesmo manter a aldeia sem plantas rasteiras, que crescem ininterruptamente, parece um modo recorrente entre os ameríndios como indicado a seguir. "A relação aldeia-mata, que encontramos em diversas etnografias é aqui recolocada como aldeia na mata, onde aldeia e mata não são faces muito diferentes de uma mesma vida sob as árvores. Isto não significa que as pessoas desejem mesclar as aldeias-acampamentos com a grossa paisagem da floresta, ao contrário. Todo novo acampamento, por mais provisório que seja, é erguido sobre uma área previamente limpa (paná'ó, "limpar"; ou tatípí "varrer"), nenhuma folha seca deve restar no solo, e o chão de terra (praticamente invisível na floresta coberta de folhas) deve aparecer por inteiro. Preferencialmente, os tapiris são feitos com folhas

\footnotetext{
${ }^{62}$ Descreverei excursões que participei que contavam com a presença feminina, mas há aquelas em que participam somente homens, como indicado em Viveiros de Castro (1986).

${ }^{63} \mathrm{Nas}$ aldeias, de forma recorrente, estão capinando no entorno das casas e dos caminhos para tirar plantas, em geral rasteiras e arbustivas, que crescem incessantemente para manter cobra e Ani distantes.
} 
novas e frescas, pois, ao contrário dos humanos, são os fantasmas Ajy que gostam de tapiris cobertos com folhas secas (Ajy tapãi, "tapiris dos Ajy)", de acordo com Garcia (2010:49) para os Awá. Em outro contexto etnográfico é observado o mesmo fenômeno. "Para os Jarawara, uma aldeia sem mato é uma aldeia bonita, arrumada, cuidada, e cada um é responsável pela parte em volta da sua casa. Inclusive, os Jarawara afirmam que existem lugares na floresta onde as plantas não crescem - que eles chamam de boto, terra limpa - e estas são localidades consideradas adequadas para a formação de novas aldeias." (Maizza 2009:57).

De volta ao acampamento araweté, para a definição do local onde instalarão seus tapiris, conta também a proximidade com as famílias do mesmo grupo doméstico situação que similar à organização na aldeia. Preferencialmente, as famílias extensas juntam-se em grupos residenciais ficando os pátios de cada família conjugal muito próximos. Estes arranjos, no entanto, acabam variando pelo espaço disponível e pela ordem de chegada das famílias no acampamento. Nos pátios, cada família conjugal instalará uma fogueira. Nesses locais ocorrem as refeições, as rodas de conversas e as sessões para tirarem carrapatos após o retorno de incursões na mata. A proximidade espacial, de certa forma, acaba indicando a proximidade social das famílias.

A presença de árvores como sapucaia e castanheira, indicadores da casa dos Ani, não intimida os Araweté, que podem se instalar embaixo dessas árvores sem a mínima cerimônia ou sinal de pavor, como de fato ocorreu quando estávamos em uma "caça" de jabotis. Assim que o local está limpo, mulheres e crianças iniciam a coleta da lenha para preparar a fogueira. A fogueira sempre deve estar ativa, seja para cozinhar, manter o calor do corpo, secar a roupa, espantar animais, especialmente durante a noite, marcando a socialidade diferencial em relação aos outros habitantes das florestas.

Cada família conjugal, representada pelo casal e pelos filhos pequenos, ficará em um tapiri. Por volta de dez anos, antes de iniciar a fase da puberdade, meninos e meninas residem em casas separadas a dos pais, embora utilizem o mesmo fogo, "pois só os casados têm fogo de cozinha" (Viveiros de Castro 1986:277). Nos acampamentos, esse modelo muitas vezes é reproduzido, o que não impede de construírem um único tapiri grande para abrigar toda a família conjugal, mesmo havendo membros jovens em período pré-matrimonial. 
Depois de montados os tapiris e armadas as redes, as mulheres vão procurar um local para cavarem as cacimbas. As cacimbas podem ser usadas por todos, mas acabam ficando setorizadas conforme a organização das casas nos acampamentos. $\mathrm{O}$ uso das cacimbas ocorre por proximidade física dos tapiris onde estão instalados. Rapidamente e em poucas horas, porções de florestas são transformadas em "aldeias".

Nos acampamentos, há uma aproximação entre as famílias pela proximidade física, pelo fato de os tapiris serem abertos, pelas rodas de conversas no fim de tarde, durante a noite e ao amanhecer, pelas trocas de alimentos e outros artefatos. Majato diz que "no acampamento todos ficam juntos, todos comem juntos, como na festa do jaboti". Mas a movimentação das famílias nos acampamentos expressa as relações próximas e distantes, sendo que uma maior proximidade é mantida entre a família conjugal e extensa, embora haja uma maior circulação entre as crianças e entre os adultos.

Ao amanhecer, a primeira tarefa consiste em reanimar o fogo. Em seguida, prepara-se o café que será consumido com farinha de milho (awatfi mepi). Um ou dois dias antes da saída para a mata, as mulheres coletam milho nas roças. O milho é, então, torrado e pisado no pilão. Esta é, outrossim, uma carga imprescindível durante a estadia nos acampamentos e mesmo nas incursões de caça na mata. Cada família leva seu saco de farinha e este é o alimento que garantirá o sustento da família nos acampamentos. A farinha de milho pode ser substituída por farinha de mandioca produzida pelos Araweté ou adquirida dos ribeirinhos, mas a preferência se dá pelo awatfi mepi.

Durante o café, os homens, sobretudo, circulam de pátio em pátio e nestas rodadas de conversas vão desenhando o planejamento do dia. Trocam informações sobre os locais de caça, relatam os acontecimentos da noite e do dia anterior. Há sempre um pátio que é o mais frequentado, seja de um ancião com família extensa presente no acampamento, seja do cacique ou de um homem bem respeitado.

As famílias se preparam para o dia na mata. Os homens verificam suas armas e, aos poucos, começa a debandada para a mata. No acampamento ficam algumas mulheres e crianças pequenas. As mulheres lavam a louça, cortam e carregam lenha, preparam o fogo, tecem tupe - "esteira" - e tupai - "saia araweté" -, cuidam das crianças, pegam 
água nas cacimbas e preparam o café para a chegada dos caçadores. As crianças ajudam com a lenha, coletam e quebram coco de babaçu e brincam. Se forem meninas mais velhas, por volta de dez anos, cuidam de pegar água e fazer o café para os pais que logo chegarão da mata.

Aos poucos, no final da tarde, as famílias retornam ao acampamento com suas caças. $\mathrm{O}$ sucesso ou o fracasso na caçada é observado por todos e, de forma velada, as famílias comparam os resultados de caça. Os homens passam para tomar café nos diversos tapiris, momento em que conversam da caçada, dos cachorros e sobre caminhos e locais de caça. Nessas conversas, árvores que servem de alimentos para os jabotis - "floresta do jaboti"-, quando este é o foco da caçada, e tipos de cursos d'água surgem recorrentemente como referências para a circulação nas florestas.

À noite, após comerem parte da caça do dia - na medida do possível buscam ter excedente de caça para levar para a aldeia - e de participarem de rodas de conversas, a rede é o abrigo certo. As conversas vão cessando e os sons da noite ecoam, como os de macaco-da-noite, da coruja e de alguns pássaros. Em algumas noites, quando há pajés nos acampamentos, ouvimos cantos acompanhados do aray. Esse é o ritmo da vida nos acampamentos que, em grande medida, espelha a dinâmica nas aldeias.

"A floresta é um local onde se come bem. Nos acampamentos de caça a fartura sempre está presente, com grandes quantidades de carne (ho'okéra), e são esses os lugares preferidos para se estar durante boa parte do ano", conforme aponta Garcia para os Awá (2010:58).

Os acampamentos são marcados pela fartura da caça, pela proximidade entre as famílias, por momentos de diversão e risadas, pelas rodas de conversas, mas também pela exposição às intempéries do tempo, pela fragilidade dos abrigos e por estarem mais expostos aos animais peçonhentos e às onças.

"É transformando a floresta em clareira que os homens criam o seu espaço" (Gallois 1988:77), mas apesar de os acampamentos se constituírem como áreas distintas nas florestas, as fronteiras não são tão nítidas e delimitadas como nas aldeias, e a presença constante do fogo nos tapiris acaba por reforçar esta diferenciação. 
Se florestas, portanto, se impõem como uma categoria distintiva composta por planos e referenciais diversos, vale agora avançar mais um passo no sentido de aprimorar o entendimento das relações e elementos que as compõem. 


\section{Capítulo II - Vegetais como índices de relações}

Se no capítulo I as florestas ocuparam a cena principal, não como um "ambiente natural", mas a partir de descontinuidades pautadas em posições diferenciais segundo perspectivas de sujeitos em ação e de categorias lógicas, guiamo-nos, agora, pelas conexões estabelecidas na relação com alguns vegetais, sobretudo aqueles encontrados nas florestas.

Aqui não faz sentido a dinâmica entre partes e todo, pois nem as florestas, nem os vegetais devem ser considerados de formas totalizadoras, especialmente quando nos apoiamos em uma abordagem que segue e destaca as conexões indicadas pelos ameríndios. Dado que o interesse principal neste capítulo são essas redes de relações entre seres e coisas, metodologicamente optou-se por posicionar os vegetais, campo este heterogêneo e polissêmico, no centro de diversas redes, onde encontros, não necessariamente apenas entre seres que compartilham a mesma natureza, marcam a participação de certos vegetais em estruturas de significação constituídas pelos ameríndios.

Assim, retornamos à base do "pensamento selvagem": "[...] Lévi-Strauss insistia em mostrar que não há nada de automático nem de previsível no modo como uma sociedade seleciona este ou aquele aspecto de seu hábitat para atribuir-lhe um significado particular e integrá-lo em suas construções míticas. Pois muitas vezes culturas vizinhas identificam em um mesmo animal, ou mesma planta, características pertinentes completamente diferentes, tanto como podem atribuir uma função simbólica idêntica a espécies que pertencem a gêneros e, até, a reinos diferentes. $O$ aspecto arbitrário que comanda as escolhas dos traços distintivos atribuídos a tal ou qual componente dos ecossistemas locais é, entretanto, temperado pelo fato de esses traços estarem organizados em sistemas coerentes, que podem ser apreendidos como os resultados decorrentes de transformações de um pequeno número de regras." (Descola 2011b:36).

Neste sentido, Fabíola Jara mostra esta temperança da arbitrariedade quando evidencia que nos mitos akuryó as relações entre vegetais, seus frutos e animais baseiam-se "[...] en el conocimiento de la dieta y del habitat de las especies. Esto no ocurre de manera 
arbitraria. Tanto en las descripciones de los frutos como de la conducta animal, ciertas relaciones son privilegiadas." (1990:98).

As qualidades sensíveis e as propriedades objetivas dos "objetos naturais", que não se configuram como matéria bruta e são selecionadas para compor "conjuntos significantes", consistem "[...] em propriedades distintivas, abstraídas do real por mecanismos de codificação e de decodificação inscritos no sistema nervoso e que funcionam por meio de oposições binárias: contraste entre movimento e imobilidade, presença ou ausência de cor, diferenças de contorno dos objetos [...]. A estrutura não seria, portanto, puro produto do intelecto pondo livremente em forma uma realidade plástica; o espírito não cessa de trabalhar estruturalmente informações que ele recebe já estruturadas pela sensibilidade." (Descola 2011b:38-39).

Vale dizer que, dada as formas como os ameríndios percebem os vegetais e as naturezas das conexões estabelecidas, diferentes orientações e trajetórias marcam as relações que os envolvem. Estes, por sua vez, assumem significados que variam contextualmente a depender do conjunto relacional que estão inseridos. A proposta aqui é abordar as múltiplas ${ }^{64}$ redes de relações estabelecidas por interlocutores indígenas que têm como base vegetais, diante das séries que estão envolvidos e o fato de serem alguns destes retidos como proeminentes a partir dos sistemas de significação locais quando a intenção é circunscrever referências ameríndias para a constituição do entendimento sobre florestas. Os vegetais serão, portanto, concebidos como índices de relações cujos significados serão constituídos à medida que estiverem inseridos em determinada cadeia relacional. Essas relações são, por sua vez, estabelecidas a partir de sistemas que não se restringem à relação parte/todo, escapando, assim, de qualquer tentativa de totalização, mas que partem de conexões nas quais pessoas e coisas constituem diferenças e semelhanças parciais no próprio processo associativo, a depender da série que estão envolvidos.

\footnotetext{
${ }^{64}$ Essa abordagem foi inspirada na noção de multiplicidade desenvolvida por Deleuze e Guatarri (2011) a partir da definição botânica de rizoma. Rizoma é um tipo de caule subterrâneo, "[...] geralmente horizontal, emitindo, de espaço a espaço, brotos aéreos foliosos e floríferos; dotado de nós, entrenós, gemas e escamas, podendo emitir raízes" (Vidal; Vidal 2003:102). Na dinâmica rizomática, segundo os referidos autores, não há posições nem pontos como em uma estrutura, mas ocorrem estratificações que marcam conjuntos significantes que, por sua vez, geram outras multiplicidades e séries heterogêneas entre seres que não necessariamente se assemelham, movimentos estes que permitem evitar cristalizações.
} 
Nesse sentido, vale ressaltar que a utilização do termo vegetal não está relacionada a uma pretensa equivalência com o reino vegetal definido por uma organização taxionômica estabelecida pela botânica. A dificuldade é justamente de tradução, sendo que o que entendemos por vegetal assume conceitos e referências diversas nas concepções ameríndias como veremos neste capítulo. A intenção é, portanto, apresentar a partir de materiais etnográficos as formas como povos ameríndios categorizam e acessam o que denominamos vegetais, tendo sempre como referência as relações e os sistemas de significação que os envolvem. A intenção com esse recorte é refinar as concepções ameríndias sobre florestas visando compor abordagens calcadas na caça e no xamanismo, por exemplo, a partir de outros enfoques.

\section{Uma categoria não nomeada}

O que significa apostar, aqui, em uma "categoria" não nomeada? Conforme veremos adiante, a ausência, entre os ameríndios, de um termo para designar os vegetais enquanto uma categoria genérica (Berlin 1973, Cabral de Oliveira 2012) não significa um vazio conceitual.

A atribuição de nomes é permeada pelo dilema filosófico segundo o qual as espécies preexistiriam à concepção dos nomes ou se o próprio ato de nomear geraria a prerrogativa de criar as espécies. Se for resultado de convenção ou produto da natureza, questão essencial apresentada por Platão no diálogo em que Sócrates discute com Hermógenes e Crátilo a respeito da origem dos nomes (Platão 2001), a relação entre linguagem, forma, conteúdo e significado permeia a discussão em curso. $\mathrm{O}$ ato de nomear pressupõe uma relação com a coisa nomeada, ou, ao menos, com a própria ideia ou imagem da coisa, que embora fixe e objetive a relação entre o nome e a coisa nomeada, não deixa de incorporar as transformações intrínsecas a esta própria dinâmica, que não se fecha em si mesma, não é bilateral e está sujeita a diversas influências. Nomear remete à existência de algo e à especificação de seres, estados e coisas a partir de determinadas características.

A "nome-ação", portanto, não é o simples ato de identificar as coisas no mundo, mas um modo de expressar pontos de vista e lógicas sobre "os mundos", ou seja, os mundos tal como acessado pelos Araweté, pelos Aweti e assim por diante. O ato de nomear - no 
caso, de espécies vegetais e animais -, mobiliza a observação e os sentidos a partir do contexto no qual se insere e, para tal, “[...] as populações tradicionais consideram as coisas vivas não somente nelas mesmas, mas também na relação que elas elaboram com o que se assemelha a elas e com o que se diferencia delas, e com o que essas populações irão fazer dessas coisas [...]” (F. Grenand 2009:238). Como apontado pela autora, para nomear algo recorremos a critérios multidimensionais e movimentos associativos e, de certa forma, seletivos a partir do momento em que na nomeação são destacadas determinadas características das coisas e seres.

O fato dos ameríndios não atribuírem um nome a uma categoria genérica e abrangente ${ }^{65}$ para os vegetais - tal como um grupo de seres vivos é classificado na taxionomia científica $^{66}$-, conforme verificado entre os Wajãpi (Cabral de Oliveira 2012), os Araweté e os Yanomami (Albert, Milliken \& Gomez 2009), entre outros, não pressupõe ausência de signo, significante e significado e, tão pouco, de conceito. Vale também marcar que entre os ameríndios, tampouco é nomeada uma categoria genérica para os $\operatorname{animais}^{67}$.

Como explica F. Grenand (2009), as categorias podem ser explícitas, isto é, nomeadas, ou implícitas, não nomeadas. As categorias não nomeadas estão presentes por reunir uma macrocategoria que é reconhecida, mas não é rotulada. O fato dos ameríndios, de um modo geral, não nomearem uma categoria vegetal genérica auto-referente, não elimina a existência de categorias que abarquem grupos de espécies vegetais, os quais não são necessariamente correspondentes às categorias delineadas pela botânica.

A nomeação de grupos de coisas compostas por vegetais e animais, ou determinado tipo de vegetal, por exemplo, liga-se diretamente a aspectos sensíveis (Lévi-Strauss 2005:15-49), aos contextos e aos sistemas de valores próprios a cada grupo, sendo que a variação do contexto gera diferenças de léxico e deslizamentos das coisas entre categorias (Grenand 2009), o que aponta para a complexidade dos saberes ameríndios

\footnotetext{
${ }^{65}$ Berlin et al denomina esta categoria como unique begginer que seria o táxon de grau zero na estrutura hierárquica taxionômica nativa proposta pelos autores: "In folk taxonomies it is quite common that the taxon found as a member of the category unique beginner is not labelled linguistically by a single habitual expression. That is, the most inclusive taxon, e.g., plant or animal, is rarely named" (1973:215).

${ }^{66}$ De acordo com Oliveira (2012), não está livre de disputas.

${ }^{67}$ Ver, por exemplo, os Jarawara (Maizza 2009:41) e os Araweté (Viveiros de Castro 1986:223).
} 
sobre os vegetais e sua relação com fatores sociais, históricos, ecológicos, linguísticos, cognitivos, como indicado entre os Yanomami (Albert, Milliken \& Gomez 2009:28).

Em alguns casos, há uma diversidade de qualificadores para determinado termo, como, por exemplo, para os diversos tipos de milho cultivados pelos Guarani (Felipim 2001); em outros, inexiste uma palavra para indicar o nome de determinada coisa ou qualidade, característica que F. Grenand (2009) qualifica como exemplos negativos por excesso, como ocorre com o termo que indica a tonalidade verde entre os ameríndios, já que vivem nas florestas em uma profusão de variedade de verdes, ou a falta de palavra para a caça em algumas populações de caçadores. No caso araweté, estes dois últimos exemplos são muito pertinentes, pois para expressar a tonalidade verde, a palavra usada é $k a^{\prime} a n a$, que significa folha, cujo atributo visível e imediato é ser representada pela cor verde, mas folha também pode ser identificada pela palavra rawe, termo que entre os Tupi, como indicado na língua wajãpi, pode significar penugem, cabelo e pelagem (Gallois, inf.pessoal); já para a atividade de caça os Araweté empregam o termo i) $\mathrm{ka}^{\prime} a$ we, que também exprime um marcador de lugar "na floresta", sendo que o morfema we é um locativo pontual que flexiona o tema nominal especificando o lugar em que se está; ii) e/ou, a palavra uata $^{68}$, que designa andar, caçar. Pode também acontecer, como entre os Yanomami, do nome usado para uma mesma planta variar conforme a região e o subgrupo, ou de membros de determinada aldeia utilizar o mesmo nome para espécies vegetais diferentes, situações que reforçam que os saberes de interlocutores indígenas sobre os vegetais não são fixos nem totalizáveis (Albert, Milliken \& Gomez 2009:28).

Nomes simples ou compostos e mais descritivos são usados para identificar vegetais, como observado entre os ameríndios, e como entre nós, quando atribuímos nomes compostos às espécies vegetais, como jasmim branco ou amarelo e repolho roxo, liso ou crespo, por exemplo. No caso dos nomes compostos, em geral, partes dos nomes expressam qualidades sensíveis e atributos que mais se destacam e assim são usados como uma maneira de distinguir os vegetais. Em outras situações, o nome do vegetal é atribuído por similaridade a partir de determinada característica da parte de animal (Cabral de Oliveira 2012). Entre os Yanomami os classificadores nominais de espécies

\footnotetext{
${ }^{68}$ A grafia uata é usada por Solano (2009:221), mas nas línguas Tupi Guarani é mais adotado o uso da letra w, como entre os Awá, cuja forma é watá e a tradução é "andar", mas também é empregado para caçar (Garcia 2010:270).
} 
vegetais "[...] vêm após o substantivo designando uma planta a fim de especificar a classe à qual ela pertence ou uma parte do vegetal descrito." (Albert, Milliken \& Gomez 2009:29).

Seguem alguns exemplos para melhor identificarmos as formas de nomeação de espécies vegetais por povos ameríndios. Entre os Juruna, hure makua (hure-ingá; makua-algodão) e yakare iwataha ("rabo-de-jacaré" para designar um tipo de orquídea com folhas largas), manakuyuha arahïhï (murici-grande e redondo) (Fargetti 2012:183184); entre os Wajãpi, ãga tawa (ãga-ingá; tawa-amarelo - possui vagens amarelas), ãgau (ãga-ingá; $u$-grande - possui vagens grandes), arara $k a^{\prime} a$ (arbusto arara pelo fato de suas flores vermelhas serem relacionadas à cor da cabeça de arara) (Cabral de Oliveira 2012:47-48). Os Pirahã nomeiam os vegetais a partir de semelhanças com animais, como: tseege, que designa formiga-fogo, é também o nome de uma árvore cujas folhas servem de alimento para essa formiga; peahauge'ai é boto e também uma árvore que "parece" com o boto, pelo fato de sua casca ser de um lado branca e, de outro, preta; maiokose significa "olho de piranha" e também nomeia uma árvore que tem uma fruta que "parece" olho de piranha (Gonçalves 2001:346-347); entre os Guarani algumas variedades de avaxí ("milho"), por exemplo, avaxí xï (milho de coloração branca), avaxí pytã (milho de coloração vermelha), avaxí ü (milho de coloração preta), avaxi pororo (milho-pipoca), jety mandiô (jety-batata; mandiômandioca, batata com forma semelhante à raiz de mandioca), jety andai ("batataabóbora" - massa de coloração alaranjada com odor semelhante ao de abóbora) (Felipim 2001:38). Os Yanomami usam o classificador $h i$ com muita frequência na nominação da categoria abrangente para árvores, como observado em wamotima tihipë, árvores frutíferas ou o yaamotima tihipë, árvores usadas como lenha; ou o classificador $t^{h} o t^{h} o$, que se refere a trepadeiras, cipós e lianas, como werehe $t^{h} o t^{h} o$, tipo de trepadeira, e wayawaya $t^{h}{ }^{h} t^{69}$, tipo de cipó (Albert, Milliken \& Gomez 2009:30).

Entre os Araweté podemos indicar alguns exemplos do que foi exposto acima: atfa'i (pau de açaí/ açaizeiro), at fa'i uhu ou pinowa'i (pau de bacaba/bacabeira; oho-grande) acredito que o mesmo uso de parte do nome está relacionado ao fato de ambas apresentarem semelhanças, no caso, morfológicas; iñapuku hu (ingá, puku-comprido,

\footnotetext{
${ }^{69}$ Respectivamente, as espécies Abuta rufescens e Gouania frangulaefolia (Albert, Milliken \& Gomez 2009:198).
} 
$h u$-grande) ou iñapuku-i ("ingazeiro"), árvore que apresenta vagens compridas com polpa comestível; iwira pidi'i (iwira- pau; pidi-vermelho; árvore de pequeno porte que produz fruto vermelho comido pelo jaboti).

Aspectos morfológicos, como indicado entre os Yanomami, são muito usados na nomeação de espécies vegetais. Os Araweté acrescentam o sufixo $-i^{70}$ a diferentes tipos de árvores, denominação que indica a presença de caule lenhoso: kopi'i - pau de cupuaçu/cupuaçuzeiro; patfi'i - pau de paxiúba/paxiúbeira; taraika'i - pau de tatajuba/tatajubeira; ñamo'i - pau de sumaúma/sumaumeira; ñapuka'i (pau de sapucaia - Lecythis paraensis Huber.); ama'i (pau de embaúba/embaubeira Cecropia $s p$ ); nata' $i$ (pau de babaçu). A presença do sufixo - $i$ configura-se similar à descrita por Oliveira (2012:75) acerca dos nomes de árvores atribuídos pelos Wajãpi quando é aplicado o sufixo "[...] 'y [pé de..., algo equivalente à nossa terminação "eira" em amoreira, goiabeira, etc.]". No entanto, entre os Araweté não são todas as espécies de árvores com caules lenhosos que o nome principal vem seguido do sufixo $-i$, como apikawi (árvore de mogno) e jenipan (pé de jenipapo). Nestes casos, esta forma aplicase tanto à espécime quanto ao seu fruto. Vale ainda notar que atfa'i (pau de açaí/ açaizeiro), atfa'i oho ("pau de bacaba") e nata'i ("babaçu") apresentam o sufixo - $i$ e seriam na taxionomia científica enquadrados na categoria das palmeiras pelo tipo de caule, lenhoso, cilíndrico e não ramificado, folhas em forma de leque e pelo fato de não apresentar crescimento lateral. Embora os Araweté hesitem em categorizar as palmeiras como iwira ("árvores"), a presença do marcador $-i$ e o pressuposto de que aplicam este sufixo a árvores com caule lenhoso e ramificado revelam que há certa fluidez nas fronteiras que designam os nomes dos vegetais e a própria constituição das categorias.

O nome de certas espécies vegetais entre os Araweté marca claramente características morfológicas distintivas: a presença de espinhos, por exemplo, é indicada pelo morfema $j u$ - espinho em nomes de certas espécies vegetais: jua - pupunha (Bactris gasipaes) palmeira que apresenta grande quantidade de espinhos, principalmente em seu caule, e tem os frutos comidos por pássaros e pelos humanos; juara'i - tucum, palmeira de grande porte que apresenta muitos espinhos no caule, seus frutos são comidos pelos peixes e araras e é encontrada em abundância nas margens do rio Xingu; jua'i - árvore

70 Corresponde ao sufixo $-y$, em outras línguas tupi-guarani e segundo comunicação pessoal de Dominique Gallois entre os Wajãpi, significa esteio, tronco e suporte. 
com tronco repleto de grossos espinhos cônicos. Um dos elementos distintivos relacionados aos espinhos é a capacidade de ferir partes do corpo; assim, espécies vegetais que apresentam espinhos remetem a determinados cuidados e $\operatorname{alertas}^{71}$ e, no caso, uma nominação distintiva.

Certo dia, no pátio da casa do cacique Tatuawi, na aldeia Djuruanti, perguntei a sua filha qual era o nome de uma árvore frondosa situada à frente de nosso campo de visão. Ela, então, disse que a chamavam ja'i rin. Este tipo de castanheira (ja'i) apresenta iwira ti me’e ("tronco branco") e foi identificada em contraposição à já $i$ hete ("castanheira verdadeira"), designação dada às castanheiras que produzem castanhas comidas pelos Araweté, pelas araras e outros animais, e que apresentam iwira rumi me'e ("tronco preto"). Ja'i rin, por sua vez, tem seus frutos comidos por araras, mas não pelos homens, e seu tronco é usado para fazer casas. Nesse exemplo, parece que é atribuída a qualidade de "verdadeira" - hete - à castanheira cujos frutos podem ser comidos pelos homens, marcando mais uma vez o caráter contextual da nomeação e que o ponto de vista determinante é daquele que tem a prerrogativa de nomear.

Diversos fatores contribuem para o modo como são concebidos, nomeados e categorizados os elementos vegetais, cujos marcadores são definidos contextualmente considerando-se, em grande medida, as qualidades sensíveis e os sistemas de significados que estão envolvidos.

\section{Princípio da similaridade para categorizar os vegetais}

A observação de características morfológicas dos vegetais ${ }^{72}$, principalmente, define algumas unidades taxionômicas nomeáveis entre os Araweté a partir da identificação de

\footnotetext{
${ }^{71}$ Tatua ru ao voltar da roça disse que furou o pé com ju ("espinho"). Ju he pa i-iwu ("O espinho furou minha mão"), foi dito por um Araweté ao se machucar com espinho. Tatuawi estava roçando o mato que crescia no caminho da cacimba próxima à sua casa, na aldeia Djuruanti, e sua esposa disse que era para tirar os espinhos que estavam abundantes, pois "espinho fura o pé da gente".

72 Carlos Lineu (séc. XVII), considerado o fundador da taxionomia moderna, criou um sistema de classificação dos seres vivos que é amplamente utilizado nas ciências biológicas. Para a classificação e sistematização dos vegetais, criou-se um modelo hierárquico a partir da observação, descrição e sistematização baseado, por sua vez, na semelhança morfológica e em características reprodutivas das plantas. No século XIX, após a apresentação por C. Darwin da teoria da evolução a partir de um ancestral comum, os taxionomistas adotaram para agrupar os vegetais sistemas filogenéticos baseados em relações evolutivas, dinâmicas e verticais. Para representar esses sistemas usaram diagramas para indicar a posição
} 
semelhanças e diferenças de aspectos externos dos vegetais, conforme exposto na seção anterior acerca da nomeação e identificação de espécies vegetais.

Sem investir sistematicamente nesse tema durante a pesquisa de campo, ficou evidente que algumas categorias mais aparentes como iwira ("árvores"), trepadeiras, especialmente cipós, e as plantas herbáceo-arbustiva são identificadas, em uma primeira análise, a partir de caracteres morfológicos. Essas categorias vegetais são muito similares às "life-form" ${ }^{73}$ representadas por árvores, cipós, gramíneas e ervas conforme apontado por Berlin el al. entre os Tzeltal, no México (1968).

Segundo os Araweté, iwira são as árvores que possuem troncos lenhosos e grossos, cujas copas estão no extrato superior, conhecido como dossel, ou no extrato arbustivo, referência que concorda com os parâmetros da fisionomia vegetal ${ }^{74}$. Quando estas árvores estão sem folhas, "sem cabelo"75 conforme informado por Iwadjma, são denominadas iwira pi. Na botânica, designam como decídua, caducifólia ou caduca as plantas que em certa estação do ano ficam sem folhas para não perderem água pelas folhas no processo de evaporação. As lianas ou cipós, plantas trepadeiras que germinam no solo e crescem utilizando as árvores ou outras lianas como suportes são denominadas ihipa. Ao radical do termo, são incorporados classificadores como ihipa radi para designar variedades. Japiwin, da aldeia Aradjyti, aponta a ramificação da batata-doce no solo e diz: - Hema ro pi jiti (jiti/batata-doce); Viveiros de Castro (1986:185-186), por sua vez, identifica hema a uma categoria de plantas trepadeiras. As plantas de pequeno porte, as ervas - entre elas, as gramíneas -, encontradas no extrato herbáceo próximo ao

de cada organismo em relação aos seus antepassados. Mais tarde, valeram-se de diagramas para representar as relações genéticas entre os organismos. Esse é o modelo predominante na taxionomia botânica, que parece não dialogar, por sua vez, com os modos ameríndios de organizar e categorizar os seres.

${ }_{73}$ Berlin et al. (1973) definem cinco ethnobiological category: unique beginner, life form, generic, specific, and varietal. Estas categorias são mutuamente exclusivas, mas quando reconhecidamente organizadas em um mesmo grupo são dispostas de forma hierárquica a partir de um grau de inclusão do genérico ao específico. Segundo os princípios apresentados pelos autores, "life form" são pouco numerosas, politípicas - apresentam mais de uma espécie - e incluem a maioria dos táxons - unidades taxionômicas - de menor grau. Os táxos do nível das "life form" são linguisticamente definidos por lexemas primários como árvores, pássaros, mamíferos, entre outros.

${ }^{74}$ Uma questão levantada em campo foi se a categoria iwira, além de aspectos morfológicos, está também atrelada a espécies vegetais que não são plantadas pelos Araweté, pois quando perguntei na aldeia Djuruanti se urucum era iwira a resposta foi negativa e a explicação foi o fato de ser plantada pelos Araweté. No entanto, esta abordagem não foi confirmada e confrontada junto a outros interlocutores.

${ }^{75}$ Vale relembrar que folha é denominada rawe pelos Araweté e como apresentado anteriormente este termo entre os Tupi significa cabelo, penugem, pelagem; portanto uma árvore sem folhas está "sem cabelo". 
solo são denominadas amãmãj ("capim") e podem crescer em ambiente terrestre ou na beira de rios, como as folhagens encontradas na margem do rio na chegada da aldeia Djuruanti. Na aldeia, os Araweté estão constantemente capinando amãmãj consideradas invasoras. Esta é uma atividade recorrente por causa da dinâmica de crescimento dessas plantas. Espécies de epífitas - plantas que vivem sobre outras plantas e se estabelecem sobre folhas, ramos, galhos e troncos, sem utilizarem seus nutrientes - com grandes folhagens são denominadas ka'ana hu - "folha grande". Neste caso, os Araweté usam como sufixo um referente de intensificação relacionado à propriedade física (Solano 2009:144-145).

Visando escapar de uma categorização hierárquica dos vegetais a partir de tipos biológicos, percebe-se a presença de outros elementos nas classificações empreendidas pelos povos indígenas. Como indicado no item relativo à nomeação de categorias que abarcam grupos de vegetais, a presença de espinhos nas plantas confere nos planos sensível e tátil, aspectos distintivos a esta característica morfológica que podem, inclusive, influenciar a forma como os vegetais são agrupados. Entre os Nalu, que habitam o sul da Guiné-Bissau, na África ocidental, "as plantas n’pinkid ("ferida") dividem-se em n'pinkid uné ("ferida branca"; Dicrostachys cinerea) e n'pinkid sé ("ferida vermelha"; Mezoneurum benthamianum). A primeira das características apontadas é considerada marcante por ser uma árvore, sendo que a outra, é uma liana. Ou seja, não pertencem ao mesmo tipo biológico e, no entanto, são sempre associadas por serem do mesmo tipo [...]. Ligam-na numa mesma categoria os traços morfológicos específicos, a existência em ambas de espinhos e a semelhança das folhas." (FrazãoMoreira 2001:148).

Analogias e diferenças relativas aos aspectos externos das plantas foram identificadas por diversos autores como elementos importantes na definição de taxionomias nativas (Jara 1990; Cabral de Oliveira 2012; Berlin 1973). No entanto, Oliveira (2012) ressalta que além dos traços morfológicos, as categorias genéricas são fundadas a partir de sobreposições de traços sensíveis que não se restringem apenas às formas dos vegetais, uma vez que são construídas a partir de referências a cheiros, gostos, texturas, entre outras. Para essa autora, o aspecto elementar das categorias fundamenta-se em descontinuidades sensíveis que definem categorias de pequena abrangência que podem ser agrupadas dinamicamente a partir de princípios diversos. Um dos exemplos citados 
em seu estudo entre os Wajãpi relaciona-se ao cheiro agradável de certas plantas como definidor de uma categoria mais abrangente que incorpora "[...] a árvore sipy, reconhecida por aspectos do seu tronco e pela presença de resina cheirosa; o gengibre, reconhecido por suas folhas e pelo rizoma tuberoso; o moi maraka, distinguido pela morfologia de seu fruto e folhas [...]" (Cabral de Oliveira 2012:44).

A despeito da ênfase na composição de vários traços sensíveis ou em outras marcas distintivas na definição de categorias vegetais nativas, características morfológicas não deixam de serem referências importantes na descrição das qualidades elencadas na classificação vegetal pelos grupos locais.

Entre os interlocutores araweté, não houve consenso se palmeiras como açaí e bacaba estavam inclusas na categoria abrangente iwira (árvores). Ellen (2001) aponta o fato das palmeiras serem raramente nomeadas como árvores pelos nativos e agrupadas em um termo específico, após análise de casos entre diversos povos habitantes do Pacífico, mas não exclusivamente. $\mathrm{O}$ autor observa que a presença de grande diversidade de árvores e de palmeiras, na região tropical, acarreta uma ambiguidade no status dessas últimas pelo fato de apresentarem uma grande variedade morfológica, além de diferenças simbólicas e multiplicidade de usos que marcam um distanciamento entre os princípios de classificação botânica e as formas de classificação e conceitualização nativas. As formas de classificação das palmeiras por diferentes povos mostram, segundo este autor "[...] the difficulty of finding operative ethnobiological classifications for particular peoples that exclude significant cultural criteria." (Ellen 2001:68). O autor conclui, portanto, que as propriedades materiais e simbólicas são, muitas vezes, mais importantes na classificação dos vegetais pelos nativos do que os aspectos morfológicos e fisiológicos, e que o léxico, muitas vezes, não reflete essa riqueza de significados e situações. Assim, Farage (1998:8), ao apresentar a classificação botânica dos Wapishana, indica três grandes categorias: plantas da mata (karam'makao), plantas domesticadas (wapao'ribao) e "as nossas plantas" (wapananinao). Esta última é identificada como uma categoria singular por possuir alma (udorona), tal como os humanos. Este princípio lhes confere intenção e vontade, característica determinante na categorização dos vegetais nesse contexto etnográfico. Entre os Jarawara, é indicado por Maizza que a classificação dos vegetais se distingue entre as plantas domesticadas, que seriam as plantas do roçado, como milho, mandioca e abacaxi, e não domesticadas, isto 
é, as plantas que não são cultivadas pelos Jarawara, como o buriti e a buritirana. Os Jarawara também utilizam para classificar os vegetais mais usados, segundo Maizza, um gradiente de força e fraqueza que está relacionado à aspectos da morfologia e da fisiologia das espécies vegetais. A referência de planta mais forte seria o tingui, decrescendo para a pupunha, o algodão e, por fim, o cará (Maizza 2009:47-48).

A maneira de perceber as qualidades sensíveis, os usos, o contexto e as conexões estabelecidas interferem na forma de identificar os seres e as coisas conforme apontam os dados etnográficos. Oliveira, ao indicar categorias inclusivas e variedades a partir de traços sensíveis, ressalta que "[...] de acordo com o contexto, o enunciador [wajãpi] pode acrescentar um qualificativo ao nome, marcando uma especificidade de determinado espécime e, assim, criar um contraste em relação aos demais (2012:38)".

Jara, a partir de uma narrativa coletada junto aos Akuryó do Suriname, reforça a importância das interconexões na classificação das plantas e destaca as relações ecológicas como operadores nas taxionomias nativas: "Las plantas no son conceptualizadas independientemente de los otros agentes del habitat. Su inclusión em la taxionomía y la nomenclarura especifica depende de sus asociaciones dentro del reino vegetal mismo o em el sistema ecológico más general." (1990:94).

Por fim, é importante chamar atenção para as questões latentes desse debate, no qual não disponho de elementos suficientes e, tampouco, pretendo investir na discussão. Mas vale ao menos apontar aspectos relevantes sobre esse fato, visando uma compreensão mais aprofundada das relações que envolvem os vegetais. Para isso, é necessário chamar a atenção para a formulação proposta por Berlin et al. ${ }^{76}$ (1973), autores de referência nessa discussão, de que a inclusão dos táxons genéricos nas categorias life form é feita por características morfológicas e pela importância econômica e seu reconhecimento está calcado em grande medida na nomenclatura. Segundo os autores, a identificação de táxons genéricos denominados por lexemas primários como banana,

\footnotetext{
76 Berlin et al apresentam uma abordagem de cunho cognitivista em que "[...] biologically natural groupings of organisms that can be referred to as folk genera" (1973:217/218). Estes autores abordam princípios gerais de classificação e nomenclatura empreendidos pela "folk biology" que são referências fundamentais em estudos de sobre as formas de se conceituar animais e plantas. No entanto, o propósito do presente trabalho não é realizar uma discussão aprofundada sobre este tema e, tampouco, apresentar dados etnográficos para validar ou analisar os princípios gerais propostos, dado que o interesse aqui é dar luz aos modos como os povos indígenas entendem e se relacionam com as florestas e os vegetais.
} 
ingá, milho, açaí, que representam a referência mais comum para grupos de organismos no "ambiente natural", são os mais salientes psicologicamente e os primeiros táxons apreendidos pelas crianças. Já os contrastes entre os táxons específicos são estabelecidos entre organismos de maior importância cultural e são distinguidos em termos semânticos, como feijão preto, feijão branco e feijão verde.

Oliveira, por estas razões, contrapõe-se à Berlin no que diz respeito à existência de uma ordem natural que estaria expressa nos táxons: "[...] creio que as taxionomias não codificam uma natureza dada, mas constroem naturezas, as quais, a posteriori, podem ser marcadas como dadas" (2012:40). A natureza não deve ser entendida como externa à sociedade, tendo em vista que a seleção e segmentação de componentes da fauna e da flora estão atreladas à atribuição de significados aos traços distintivos que são organizados em sistemas coerentes.

A abordagem cognitivista de Berlin $(1973)^{77}$ coloca ênfase na categorização de tipos naturais ancorados em características materiais e aparentemente inatas no processo de decodificação da natureza (Bloch 2001). No entanto, ao desconstruir o referencial cognitivista, Bloch, que empreendeu seus estudos entre os Zafimaniry, em Madagascar, sudeste da África, observa que as analogias conceituais produzidas em termos simbólicos caracterizam descontinuidades e continuidades, e que este aspecto é fundamental na categorização das plantas pelos nativos. Os sistemas nativos de classificação de grupos que abarcam vegetais são dinâmicos e consideram o contexto e os dados etnográficos mais abrangentes para a sua composição.

O princípio da similaridade coloca em evidência determinadas características que podem, inclusive, sobrepor-se, e remetem não apenas à experiência e ao mundo material por si, mas, sobretudo, a associações formuladas entre elementos selecionados a partir de contextos de significação. As semelhanças e diferenças são estabelecidas no próprio

\footnotetext{
77 Berlin et al apresentam uma abordagem de cunho cognitivista em que "[...] biologically natural groupings of organisms that can be referred to as folk genera" (1973:217/218). Estes autores abordam princípios gerais de classificação e nomenclatura empreendidos pela "folk biology" que são referências fundamentais em estudos sobre as formas de se conceituar animais e plantas. No entanto, o propósito do presente trabalho não é realizar uma discussão aprofundada sobre este tema e, tampouco, apresentar dados etnográficos para validar ou analisar os princípios gerais propostos. O interesse aqui é dar luz aos modos como os povos indígenas entendem e se relacionam com a floresta e os vegetais.
} 
processo comparativo, não estando calcadas apenas nas coisas, as quais atuam como referentes para a elaboração dos significados.

Se podemos apontar o princípio da similaridade como imperativo nas taxionomias nativas, é fundamental enfatizar que, se, por um lado, são destacados diversos traços sensíveis, e entre eles a morfologia assume um papel fundamental, por outro, as condições contextuais que abarcam sistemas de significados, atributos materiais e dinâmicas ecológicas operam na constituição de classificações indígenas. Deve ficar claro que, entre os Araweté, e no material bibliográfico levantado, não foi indicada uma macrocategoria genérica para os vegetais, mas categorias que reúnem grupos de vegetais a partir de referenciais diversas, como demonstrado nesta seção. A variedade de referenciais usados para compor categorias que abarcam vegetais entre os ameríndios, os quais não são cristalizados, contribui para indicar, mais uma vez, que múltiplos operadores são utilizados para compor essas formas classificatórias e que diversas conexões estão em jogo nesse processo.

\section{Reprodução e crescimento dos vegetais}

O entendimento das partes e da metamorfose das plantas atraiu Goethe (1993) que a partir da observação das qualidades sensíveis, descreve o crescimento dos vegetais e o processo de transformação de uma forma para outra. O referido autor busca na multiplicidade uma unidade e um princípio, explorando uma perspectiva dinâmica que considera os vegetais em seu devir - e não como seres fixados -, em que há um encadeamento das partes não em termos evolutivos, mas a partir de uma concepção prédeterminada. Este estudo contribuiu com a reflexão de Lévi-Strauss sobre o princípio de descontinuidade inerente às classificações e ao entendimento de que "[...] cada mudança descontínua impõe a reorganização do conjunto, pois nenhuma delas ocorre isoladamente, mas sempre em correlação com outras." (2011:652). As descontinuidades são, então, instituídas por combinações e oposições distintivas a partir de elementos sensíveis e de construções no âmbito do inteligível. O idioma sensível e as transformações inerentes à matéria que se organizam de forma espontânea no tempo e no espaço não são apreendidos em si, mas "[...] pela ação conjunta dos órgãos do 
sentido e do entendimento [...]"78 (Lévi-Strauss 2011:654).

Para os Araweté, as partes externas dos vegetais são identificados por hapa (raiz dela)/rapa (raiz de), rat $\int i$ (galho de)/i (pau/tronco), ka'ana (folha)/rawe (folha de)/hawe (folha dela), poti (flor), ã (fruto) e tinã (semente) são, em geral, relacionadas à própria planta: akaju-i rat $\int i$ (galho de cajueiro), padidi-i rawe (folha de bananeira), ihipa poti (flor de um tipo de cipó); mumu-i poti (flor-de-mamão) e iwira ã (fruto). As partes das plantas, por sua vez, ligam-se ao todo e implicam em uma manifestação relacional entre um núcleo dependente, ou seja, à parte, e seu determinante ${ }^{79}$, o todo, no caso a própria espécie vegetal, cujo referencial é sempre o todo, como segue: iriku rai (semente de urucum; iriku/determinante e rai/determinado), padidi-i rawe (folha de bananeira), ñapuka-i poti (flor de sapucaia) e itiri-i hi (resina cheirosa da árvore itiri-i). Como abordado por Lima entre os Yudjá, partes do corpo são sempre referenciadas a alguém, como, por exemplo, "o pé de alguém". Este modo de operar indica que "[...] um corpo é, depende intrinsecamente, fundamentalmente, de uma perspectiva." (2002:13). Esse princípio pode, então, ser aplicado a forma de relacionar as partes que compõem um vegetal, bem como nas relações entre vegetais e entre esses e outros seres. As correlações estabelecidas entre vegetais e a discussão sobre corpos pode ainda ser corroborada pela analogia quanto à morfologia de corpos - de humanos e de vegetais quando usam o mesmo léxico para qualificar partes do corpo. Entre os Pirahã, a dinâmica entre partes e o todo sempre é observada de forma contextual, e a relação entre criação dos vegetais e corpo humano torna-se evidente. "Os abaisi ${ }^{80}$ vão fabricando os vegetais por partes, até formar um conjunto pelo qual a planta pode ser identificada. Processo semelhante ocorre, também, entre determinados vegetais - não somente os cultivados, mas também aqueles que fazem parte da cultura material - e as partes do

\footnotetext{
${ }^{78}$ A discussão acerca do sensível e do inteligível empreendida por Lévi-Strauss acaba por não dissociar essas manifestações por entender que são correlatas da mesma realidade. "Tal elaboração se faz simultaneamente em duas direções divergentes: por decomposição progressiva do sintagma e por generalização crescente do paradigma" (Lévi-Strauss 2011:654). Uma corresponde ao eixo metonímico e outra ao metafórico.

${ }^{79}$ Entre os Araweté as classes de nomes, verbos e posposições são flexionáveis, marcam relações entre um núcleo dependente e seu determinante, sendo a flexão relacional comum a estas três classes. Há tipos de relações de dependência (subordinação e determinação) entre um tema determinado e seu determinante (expressão precedente) indicadas pela combinação de prefixos relacionais marcados por diferentes alomorfes: a) ( $\mathrm{r}[\mathrm{r} \sim \mathrm{n} \sim \mathrm{d}]$ - relação de dependência com determinado; b) i, t, h - determinante não estabelece relação de continuidade e não forma unidade com determinado; c) t, v - determinante é genérico e humano, para citar alguns alomorfes e tipos de relações de dependência conforme indicado por Solano (2009:96-97). Como exemplo, podemos citar: rawe (folha de)/ hawe (folha dela) ou hapa (raiz dela)/ rapa (raiz de).

${ }^{80}$ Os abaisi são seres que habitam o cosmos e detêm o poder da criação e da destruição.
} 
corpo humano. Da mão do homem surgiu a mandioca, da mão da mulher, a macaxeira. A banana originou-se da cabeça, e o cará, do pé [...]" (Gonçalves 2001:345). Entre os Kisêdjê, as plantas originaram-se de partes do corpo de uma ancestral e disso resulta o modo de sua reprodução. "Da cabeça, vieram as cabaças; de seus ossos, o cupá (um cipó comestível, Cissus sp.); das pernas, milho; dos pés, inhames. Essas origens têm consequências sobre as práticas de cultivo contemporâneas: pessoas com pés pequenos não devem plantar inhames, pois estes não crescerão [...]; mulheres de perna fina não devem plantar milho, por razões do mesmo tipo [...]" (Coelho de Souza 2014:208).

Podemos analisar a relação entre as partes e o todo no processo de reprodução dos espécimes vegetais a partir do princípio metonímico. O princípio reprodutivo está determinado nas partes, configuradas como totalidades relativas de uma concepção prédeterminada - neste ponto retomamos a análise de Goethe (1993), citada anteriormente. Partes e todo carregam implicitamente uma ordem a qual estão subordinadas e, assim, estabelecem uma relação de contiguidade e dependência que desencadeia um movimento de reprodução e crescimento constantes em que uma estética das transformações conecta uma forma em outra. Nesse sentido, também foi apresentada estreita conexão entre vegetais e corpo humano.

Dado que corpos existem para e em relação, vejamos agora o princípio da reprodução de vegetais na perspectiva araweté. As sementes das espécies vegetais são indicadas pelos Araweté como $r a^{\prime} i$ (filho de), $r a^{\prime} i$ di (filha) ou $t^{\prime} i$ (filho dele ou filho genérico) ${ }^{81}$ em relação à planta-mãe e/ou a mesma espécie vegetal em fase adulta, terminologia esta empregada nas relações entre pais e filhos ou para indicar o filho de alguém ${ }^{82}$. O termo ta'i também é aplicado ao broto e muda de planta e tairuhu significa criança. Percebi essa relação entre a forma de denominar a relação entre plantas-mãe e sementes e pais e filhos durante minha estadia na aldeia Ta'akati, quando Karapihi abriu um fruto de urucum, pegou a semente e disse: - Iriku ra'i/ Semente/filho de urucum! Em outro momento, quando andávamos na capoeira de Tatuaru, nas imediações da aldeia Taakati,

\footnotetext{
${ }^{81}$ Radi (filha), tadi (filha dele ou filha genérica) (Solano 2009:104). Para aprofundar sobre terminologia de parentesco consultar Viveiros de Castro (1986:390-404).

${ }^{82}$ Viveiros de Castro (1986:396) indica que ta'í aplica-se à relação de um homem com seu filho, ou filho de seu irmão, sendo a forma possessiva indicada por he ra'i, sendo o vocativo api, hadi. "Ta-i é uma forma genérica para "filho", criança, broto de planta" (op.cit.:437). Dominique Gallois em comunicação pessoal informou que na língua wajãpi ta'yry é filho tanto de gente como de tudo, pois vale para vegetais, animais e diferentes coisas.
} 
sua nora, Iwadjma, ao avistar um talo de uma planta que estava nascendo, identificou-o como ta'i. Durante uma caminhada na mata para pegar jaboti, mostrei para Karapi hi uma semente e ela disse: - Juta-i ra'i (semente de jutaí).

Como fundamento dessa relação estão as noções de criação e de cuidado. Em princípio, há duas categorias de criação, como observado entre os Araweté: autocriação, quando os vegetais se auto-reproduzem e não são plantados por alguém, como é o caso de alguns vegetais encontrados nas florestas e que foram "deixados" ou "abandonados" pelos deuses na terra quando estes subiram para o Mai pi; e a criação por outrem, no caso de serem plantados por alguém. Em ambas as situações, a reprodução do próprio ser - tanto de suas partes quanto do todo - gera seus múltiplos.

A noção de criação é fundamental no processo de reprodução dos vegetais no sentido de proporcionar condições para o seu desenvolvimento. Plantas e humanos criam-se e são criados mutuamente. Os modos como se relacionam transformam não apenas as condições materiais, mas a si mesmos e àqueles que fazem parte de suas redes de relacionamentos. Ingold (2000:77-88) discute a antinomia entre fazer e crescer, segundo a qual fazer remete à representação da impressão da ordem social sobre o substrato material, e crescer, noção da qual é partidário e que se aplica aos cuidados com os filhos e cultivo de plantas, ao entendimento de que os seres humanos contribuem com as condições para o crescimento destes seres e que não é uma relação unilateral. Este entendimento pode ser expandido para o modo como os Araweté expressam o crescimento dos vegetais tendo em vista que, certo dia, Iwadma apontou, atrás da casa de Tatuaru, ramos de cará (kara) em crescimento. Kara são plantas trepadeiras que crescem rasteiras sobre o solo. Ao mostrar a ramificação do kara usou o termo ta'i (kara ta'i) para os ramos em crescimento e $i-m u h i^{83}$ (ciração dele, no caso, Tatuaru) para a dinâmica de crescimento. A associação entre reprodução dos vegetais e uma certa forma de cuidar pode ser reforçada pela observação de que entre os Araweté "[...] a criação é uma "posição de ser"; ela se distingue da "fabricação" (moni ou apa), ato concebido como uma elaboração demorada de uma matéria-prima." (Viveiros de Castro 1986:223).

\footnotetext{
${ }^{83}$ Os Araweté usam a expressão muhi mire para se referir à gente ou ser criado - muhi / crescer; -mire nominalizador que deriva nomes pacientes de verbos transitivos e intransitivos (Solano 2009:314) -; he $m u h i$ - eu criei, i-muhi - criação dele, onde muhi é criar / crescer.
} 
Crescimento dos vegetais entre os ameríndios pode também estar relacionado a condições cosmológicas, como entre os Jarawara onde "[...] todas as plantas domesticadas, ou seja, plantadas pelos Jarawara, são também e ao mesmo tempo espíritos no céu chamados de 'filhos' daquele que a plantou e filho da espécie vegetal à qual ela pertence" (Maizza 2009:49); ou como no caso achuar, cujo desenvolvimento das plantas cultivadas depende de requisitos simbólicos para sua efetividade sendo que a maternidade oferece o modelo das operações relativas às plantas cultivadas. Ao proferirem os cantos anent para as plantas cultivadas as mulheres estimulam seu crescimento como uma mãe faz com seus filhos. Identificando-se com Nunkui, ser que é criador e mãe das plantas cultivadas, a mulher achuar apropria-se da relação de maternidade entre aquele e as plantas cultivadas (Descola 2005:292). Davi Kopenawa, xamã yanomami, por sua vez, relata que "as árvores da floresta e as plantas de nossa roça também não crescem sozinhas, como pensam os brancos. Nossa floresta é vasta e bela. Mas não o é à toa. É seu valor de fertilidade que a faz assim. É o que chamamos në rope. ${ }^{84}$ Nada cresceria sem isso." (Kopenawa \& Albert 2015:207).

Além disso, como para os Huaorani, encontrados na Amazônia Equatoriana, a observação do crescimento orgânico de vegetais aplica-se à dinâmica social. Percebem pelo domínio prático que o crescimento e maturação das árvores ocorrem a partir de diferentes escalas: i) plantas de crescimento mais lento, como a madeira dura de pupunha, relacionam-se à continuidade das gerações que plantam, reproduzem e consomem a pupunha; ii) plantas de crescimento rápido e vida curta, como a mandioca, que entre os Huaorani é mais utilizada para preparo de bebida ritual do que para subsistência, ligam-se à expansão de novos casamentos além do limite do grupo. Os Huaorani estabelecem uma correlação entre o crescimento de uma palmeira, a pupunheira, com a passagem das gerações humanas e a dinâmica de grupos locais huaorani, sendo que a história de crescimento dessas palmeiras liga-se à história dos grupos locais e, em outra escala, fazem uma conexão entre a mandioca e a balsa - tipo de árvore que possui uma madeira muito leve -, que necessitam de áreas abertas para o crescimento, e a dispersão dos grupos e das pessoas (Rival 1993:641-648).

\footnotetext{
${ }^{84} \mathrm{Em}$ nota, há o esclarecimento que $n e ̈$ rope "é o 'valor de fertilidade' da floresta enquanto agente (nё ropeni) que faz as plantas crescerem nela. [...] Në rope é um estado/princípio de fertilidade compartilhado por plantas cultivadas e selvagens." (Kopenawa \& Albert 2015:631). O tema da agência, no caso, das plantas, será abordado na seção denominada 'princípio vital e gradiente de agência das árvores'. Em outro trecho, Davi Kopenawa afirma também que "as folhas e as flores das árvores caem e se amontoam no solo sem parar. É isso que dá à floresta seu cheiro e seu valor de fertilidade. (op.cit.:471).
} 
O fato é que não está em disputa a primazia entre a base material e orgânica ou simbólica no entendimento das relações estabelecidas a partir dos vegetais, pelos vegetais e a vida social dos humanos, mas em ressaltar a simbiose entre esses campos que, justamente por esta característica, não devem ser analisados como metáforas para a apreensão de cada qual, mas a partir de lógicas inerentes à própria dinâmica das transformações e das relações em curso.

\section{E as árvores têm donos?}

Para os Araweté a maioria das espécies vegetais encontradas nas florestas não possuem donos, noção chave nas cosmologias ameríndias, mas que para eles não permeia tão intensamente todos os domínios do cosmos e das relações vigentes.

A relação de maestria "[...] designa uma posição que envolve controle e/ou proteção, engendramento e/ou posse, e que se aplica a relações entre pessoas (humanas ou não humanas) e entre pessoas e coisas (tangíveis ou intangíveis)." (Fausto 2008:330). Essa noção pode ser aplicada a animais de estimação, espécies vegetais plantadas por alguém, lugares, coisas, bens, mestre de cantos, de rituais e assim por diante, como indicado em diversos contextos etnográficos.

Para os Wajãpi, todos os domínios e seres do cosmos possuem donos, relação marcada pelo controle e cuidados, predação e domesticação. Os donos devem tomar conta de suas criaturas para garantir seu desenvolvimento e reprodução. Para os Wajãpi, há múltiplos mundos, cada um controlado por um -jar ("donos") que cuida de seus xerimbabos, eima ("criaturas"), que abarcam plantas, animais e objetos. "[...] a principal atribuição de um -jar é controlar o desenvolvimento de suas criaturas, evitando a extinção da espécie" (Gallois 1988:63). Situação similar ocorre entre os Kalapalo, na qual espaços na aldeia e na mata, como rios, lagos e morros podem ser moradas de espíritos e se configurar a partir de gradientes de periculosidade. "Toda a paisagem é social logo de saída e, ao lidar com ela, ao arrancar uma planta, queimar um mato ou derrubar um morrinho, é preciso ter em mente que pode-se estar entrando em relação com seus donos." (Guerreiro Júnior 2012:229). Entre os Awá, segundo Garcia (2010), a relação entre xerimbabos (-nimá) e "seus donos" (jara) é denominada riko e está 
vinculada a uma multiplicidade de sistemas de ação que envolve cuidados e não implica necessariamente em controle. "E mais do que uma relação de controle, o que no caso Awá-Guajá nem sempre será, trata-se sim de uma relação assimétrica, orientada, donde um nimá sempre "estará associado" (rikô), ou será "criado" (rikô), por um jará." (Garcia 2010:222).

Entre os Araweté a noção $\tilde{n} \tilde{a}^{85}$ "[...] conota idéias como a de liderança, controle, representação, responsabilidade, propriedade de algum recurso ou domínio. O $\tilde{n} \tilde{a}$ é sempre um ser humano ou antropomorfo. Mas ainda há outras ideias envolvidas. O $\tilde{n} \tilde{a}$ de algo é alguém que tem esse algo em abundância. E, sobretudo, o ñã é alguém que é definido pelo algo de que é o senhor." (Viveiros de Castro 1986:233. Grifos do autor.)

Para os Araweté, os animais criados por alguém ${ }^{86}$, as plantas na roça, as coisas e os pertences das pessoas nas aldeias possuem seus donos que são aqueles que os criaram ${ }^{87}$, fabricaram e/ou adquiriram. Já a reprodução de vegetais e animais ${ }^{88}$ encontrados nas florestas, como apontado em outras seções, em grande medida, ocorre pela autocriação, modo de existir que se contrapõe àquele dos seres criados por outrem e está vinculado à categoria araweté ika hete me'e, ou seja, dos seres que "simplesmente existem". "A noção ika hete $e^{\prime} \underline{e}$, ao se opor a dos animais temima $\underline{a}^{89}$, de estimação, designa então o indomado versus o domado, o que se come versus aquilo que se guarda em cercado ou se cuida (ipa'î). Mas ela se opõe ainda a uma noção mais geral, a de seres "das divindades (Maï apa) [...] O que se conota, aí, é menos um modo de existência "não-

\footnotetext{
${ }^{85}$ Este termo é homônimo à $\tilde{n} \tilde{a}$, com significado de "jaguar", mas não devem ser confundidos semanticamente.

${ }^{86}$ Animais criados, diferentemente de plantas da roça, não são para serem comidos.

${ }^{87}$ Segundo Viveiros de Castro o termo para criação é mara que se traduz "[...] literalmente como "colocar", "por", "presentificar" - isto no sentido tanto locativo (pôr algo em algum lugar), como metafísico [...] Mara é, propriamente, pôr como existente, atualizar" (1986:223). Para criar no sentido de cuidar, Viveiros de Castro, indica o termo ipa'e. Solano (2009:189) traduz o verbo mara como enviar, mandar e indica que o mesmo é complemento da posposição -ehe -e 'em relação a, sobre'. Diante do exposto, vale reforçar que o termo "criar" está atrelado à existência, marca posições e relações sociais estabelecidas e será usado tanto no sentido de criar quanto de cuidar.

${ }^{88}$ No caso dos animais, segundo Viveiros de Castro (1986), há os seres que sempre existiram como o jaboti e algumas espécies de insetos e de peixes, mas a grande maioria foi criada, no sentido de colocados como existentes, estando entre eles o gavião, urubu, onça, guariba, veado, jacu, paca, tatu e outros.

${ }^{89}$ Temimã são os animais de criação, sejam dos homens como de outros seres; os temimã não podem ser comidos por aqueles que os criam. Os homens costumam criar araras, cachorros e galinhas - estas últimas introduzidas pelos não índios. Tajahu são criados em cercado por Iaradï, Senhor dos Queixadas que têm a prerrogativa de controlar a disponibilidade desses animais. Inclusive Tiñara du disse que quando não há carne disponível, solicitam aos pajés para demandarem que Iaradi libere tajahu na mata. "Iaradï e Mo'iroco, os Senhores dos Queixadas, [...] não come essa espécie - ele "cuida" (ipa'i) dela, e parece controlar sua reprodução" (Viveiros de Castro 1986:234).
} 
possuído" que um modo indeterminado ou a-significante de existir." (op.cit.:228. Grifos do autor.)

Assim, os vegetais plantados pelos Araweté, pertencem ${ }^{90}$ aos responsáveis pelo seu plantio e cuidados contínuos. Madai ru, então, é dono do mumu $i$ ("mamoeiro") que plantou em seu quintal. As espécies vegetais consumidas pelos Araweté como açaí, bacaba e castanha, situadas ao longo de caminhos abertos nas florestas e mantidos pelos pais de família, pertencem àqueles que tiveram o trabalho de abrir os caminhos, embora não tenham sido plantadas por eles. Nesse caso, seus frutos não devem ser coletados por outras famílias. Essas são duas situações nas quais as espécies vegetais pertencem aos homens, seja porque estes últimos acompanharam e incentivaram seu crescimento, seja porque abriram caminhos no percurso onde aquelas árvores estão localizadas. Vale ressaltar que em nenhum momento essas relações são qualificadas pelo termo $\tilde{n} \tilde{a}$ ("dono"), o qual, inclusive, é raramente empregado pelos Araweté. Convém também apontar que entre os Aweti (Figueiredo 2010) e os Kalapalo (Guerreiro Júnior 2012) os caminhos igualmente pertencem àqueles que fizerem e fazem um esforço para abrir e cuidar de sua manutenção, mas não houve a indicação pelos autores de relação estabelecida por aqueles que abriram os caminhos com espécies vegetais encontradas na passagem.

Por sua vez, o atfa'i ("pé de açaí") como o kopi'i ("pé de cupuaçu") encontrados nas florestas pertencem aos Ani. Seus frutos podem ser consumidos pelos humanos, mas as árvores não podem ser derrubadas, pois, neste caso, os Araweté dizem que "Ani fica bravo; ele mata a gente". Se os Araweté derrubam alguma árvore de cupuaçu, dizem que seu dono, kopi'i ña a, vai atrás. Majatu ru disse atfa'i pode derrubar, pois usam para fazer paneiros; o que não pode é derrubar muitas palmeiras. Ani mora em ocos de árvores, como dito anteriormente, como o kopi'i ("cupuaçuzeiro") e o atfa’i ("açaizeiro"), e nem por isso são considerados donos de todas as árvores onde residem, como de castanheira, sapucaias ou outras; portanto, não é apenas o fato de morarem em ocos de certas árvores que assegura a relação de maestria, pois não são considerados

\footnotetext{
${ }^{90}$ A raiz nominal -apa é traduzida como "pertence" ou "bem" (Solano 2009:147). "Apa significa coisa em geral. Quando usado em construções do tipo: (substantivo) + apa, pode conotar tanto uma idéia de propriedade, quanto a de pertinência de algo a alguma outra coisa (o substantivo-sujeito)" (Viveiros de Castro 1986:228). Os Araweté disseram: iriku ("urucum") he apa X ñamu`i ("sumaúma") que não é considerado he apa; urucum é plantado por alguém e sumaúma não é plantada; a casa de alguém é considerada he apa pelo fato de ter sido construída por aqueles que se consideram seu dono.
} 
donos de os espécimes de árvores com a presença de ocos onde seriam sua morada. Um Araweté enunciou uma relação de maestria entre açaí e cupuaçu e os Ani alegando que foram plantados pelos Ani, mas essa não é uma interpretação corrente, sendo que também concebem que essas espécies "se criam sozinhas". Considero pertinente para a relação de maestria entre os Ani e essas espécies vegetais a abordagem assumida no caso aweti para a noção de itat ("dono"), que "[...] não precisa ser associada a relações de cuidado, domínio ou posse, mas simplesmente à marcação de intensidade na relação entre um sujeito e um objeto, em comparação a outros sujeitos." (Figueiredo 2010:221. Grifos da autora). Ser dono não denota controle do bem; neste caso a maestria "[...] constitui um sujeito através do olhar do outro" (op.cit.:222). Assim, a presença de kopi'i ("pé de cupuaçu") e de at fa'i ("pé de açaí") marca a posição dos Ani e impõe aos Araweté um modo de se relacionar com essas espécies vegetais. Por outro lado, quando o atfa'i está no caminho de alguma família araweté, pertence a esta última no sentido de ser responsável por mediar o uso de suas partes e o consumo de seus frutos. Dessa forma, ora a relação mais evidente com o atfa' $i$ é estabelecida como de pertencimento aos donos de caminhos na mata, ora aos Ani; característica que evidencia que não são relações fixadas, mas balizadas por perspectivas calcadas em um contexto relacional e situacional $^{91}$. A transgressão no consumo em quantidade dos frutos dessas árvores por outros que não aqueles que empreenderam esforços para abrir os caminhos na mata sem a devida permissão não acarreta em consequência fatal. Já na relação mediada pelos $A n i$, o não cumprimento das regras estabelecidas relativas ao modo de se relacionarem, geram atos de vingança que podem acarretar em morte.

As relações entre donos e lugares de moradia, ou donos e plantações, em se tratando de espécies vegetais é explicitada entre os Wajãpi, para quem Oliveira (2012:73) ressalta a relação entre "1) -jarã e -remitã, que se refere a um dono e seus cultivos, o que se aplica tanto a uma mulher (que ocupa a posição de -jarã) em relação a seus cultivares (remitã), como as plantações dos demais seres do cosmos;2) -jarã e -retãa, referente à relação que os donos das árvores possuem com esses vegetais - a de suporte, morada" (2012:73). Mas, conforme dito anteriormente, se para os Wajãpi "[...] cada porção do universo é definida como a morada de seu dono e é descrita como o suporte das

\footnotetext{
${ }^{91} \mathrm{Na}$ coleta de jaboti, ao avistarem a murerawi - fruta que jaboti come -, disseram-me que essa árvore "se criou no mato" e que jaboti era seu dono por estar comendo o fruto. Não consideram, no entanto, o jaboti o dono desta árvore independente de uma situação, mas ao consumir seu fruto, que no caso é uma referência na alimentação deste réptil, gerando uma relação de associação e proximidade.
} 
espécies que ele controla" (Gallois 1988:63), os Araweté "[...] não parecem conceber de modo geral o cosmos como consistindo em um conjunto de domínios (e seus seres) justapostos, possuídos por diferentes $\tilde{n} \tilde{a}$ com quem o homem precisa se entender e lutar [...] Pelo menos esta não é a ênfase de sua cosmologia." (Viveiros de Castro 1986:233) ${ }^{92}$. Assim, os humanos não necessitam negociar constantemente com os Ani ou quem quer que seja para circular nas florestas ou mesmo fazer uso de certas espécies vegetais, o que não exclui cuidados específicos e atenção constante.

Por sua vez, diferentemente, em certo sentido, da situação descrita entre os Awá-Guajá, na qual "[...] a relação rikô sugere a idéia de dono de um espécime, e não dono da espécie" (Garcia 2010:224), embora esta relação, como enfatiza o autor, possa vir a ocorrer de forma menos intensa, os Ani são considerados donos a priori dos atfa 'i ("pé de açaí") e dos kopi'i ("pé de cupuaçu"). Mas aqui continua valendo, como bem aponta Garcia, o contexto relacional e, neste caso, entre os Araweté a ênfase relacional e a posição de cada ser que terá de ser confirmada na experiência da relação.

Juara'i é outra espécie vegetal encontrada nas florestas que tem $\tilde{n} \tilde{a}$ (dono). É permitido derrubar esta palmeira, mas não se pode comer seu fruto, pois o seu consumo leva a um estado de "loucura", hadi. "Yuará'i ñã, "Senhor do tucum". Esse espírito treme e cheira mal. Ele causa tremores e convulsões em recém-nascidos. As mulheres grávidas não devem ter relações sexuais perto de um pé de tucum, pois os seus filhos sofrerão de convulsões (hadi)." (Viveiros de Castro 1986:244). Essa é uma situação cuja ingestão dos frutos acarreta em perigo aos humanos, como que por uma troca de substâncias, os homens sofrerão de infortúnios, mal-estar e perda de consciência gerada pelo estado de loucura ao entrarem em contato direto com Ani. Entre os Aweti, as plantas usadas na reclusão pubertária têm donos e, a despeito de ser recomendado seu uso para provocar vômito ou para as escarificações produzidas na pele, certas precauções devem ser tomadas em relação aos donos dessas espécies, sob o risco de morrer ou adoecer (Figueiredo 2010:214-215). Verifica-se, assim, que em algumas situações as espécies que têm donos são perigosas, mas os perigos advindos delas ligam-se mais ao modo de

\footnotetext{
${ }^{92}$ Um Araweté reatou-me que Ipá era dono do parani, rio. Ipá é inimigo da gente, pega as mulheres que estão na beira d'água, especialmente as grávidas, quando tem aparência masculina. Também pode ter aparência feminina e aparecer para os homens. Ipá é dono da água. Não pode ficar sozinho na beira, pois nesta condição Ipá pode aparecer. O contato com Ipá provoca doenças que são curadas pelo pajé.
} 
se relacionar com essas espécies e ao cumprimento de certas regras e etiquetas. Por outro lado, a eficácia de espécies vegetais usadas para fins terapêuticos também pode estar atrelada a seus donos. Assim dizem os Guarani Mbya quando "[...] Vera é enfático em afirmar que a potência e a eficácia da planta dependem diretamente do seu dono. Se o dono não autorizar o uso, a planta não vai funcionar." (Testa 2014:119).

Sobre a iwiriti ("mata-mata"), Kuruama ru disse-me que "não tem dono, nasceu sozinha, ninguém mora nela". Este modo de enunciar vincula, de forma recorrente, espécies vegetais encontradas nas florestas. Em outras palavras, não é estabelecida necessariamente a relação de maestria com árvores que consideram que se reproduzem e crescem sozinhas. Entre os Araweté, as árvores encontradas nas florestas enquadram-se, em geral, na categoria de seres que nascem e crescem sozinhos como as espécies vegetais indicadas a seguir: muru'i, taraikã'i, ñamu $i$ - sumaúma, akao - cacau, atfa'i oho - bacaba, ja $i$ - castanheira, itiri $i$ - árvore que produz resina cheirosa - e diversas outras espécies. "Iwira ('árvore') não tem dono. Ela mesma criou, igual ao mato, fica criando sozinha, ninguém plantou", assim me disse um Araweté, fazendo eco a seus parentes sobre boa parte das árvores encontradas nas florestas.

Viveiros de Castro aponta que "Iwirãa-ñã, 'Senhor das árvores', parece ser quem planta as árvores sem donos próprios na floresta" (1986:244), e que os "[...] $\tilde{A} \tilde{n} \underline{i}$ não são os 'donos dos animais' ou 'donos da mata"' (op.cit.:216). Tatuaru, por sua vez, disse-me que "Ani é dono de todas as árvores, iwirã ñã. Ani é dono de tudo, iwirã ñã". Vale lembrar que Mai "deixou" espécies vegetais na camada terrestre quando subiu ao firmamento e que à akoti-uhu ("cotia grande") foi atribuída a plantação das árvores que compõem as florestas. É, portanto, importante ressaltar que se em outros tempos as árvores e palmeiras encontradas nas florestas foram plantadas por alguém ou deixadas na plataforma terrestre por Mai, por mais que alguns interlocutores digam que Ani é iwira $\tilde{n} \tilde{a}$ ("dono das árvores") ou que iwira ñã planta as árvores que não têm donos, a ênfase para os Araweté está no entendimento de que as árvores encontradas nas florestas se criam sozinhas; dito isso, se nem tudo é plantado, nem tudo possui rigorosamente um dono e, portanto, os Araweté não necessitam negociar constantemente com alguém para circular nas florestas e, tampouco, estão expostos recorrentemente à perigos advindos de donos de espécies vegetais. No caso araweté há expressões gerais para donos das árvores, como indicado acima, mas correntemente reforçam que as árvores nas florestas 
não possuem donos - exceto os casos já descritos. Assim, formas de enunciação generalizantes atenuam ou mesmo anulam eventuais efeitos de uma relação de maestria.

A noção de maestria opera por esquemas relacionais em diferentes escalas e atua como um balizador cosmológico (Fausto 2008), mas, como vimos em diversos contextos etnográficos, há variações de grau, escopo e, em certa medida, do tipo de relação operada. Os donos das árvores, quando esta relação se faz vigente, podem estabelecer relações de cooperação, vingança ou apenas manifestar de forma intensificada a sua presença sem causar qualquer consequência danosa aos humanos que delas se utilizam ou que delas se aproximam. Esses gradientes marcam diferenças relacionais e atuam menos como operador regulador e mais como balizador das relações, no caso, entre vegetais e seres do cosmos.

\section{Árvores e aves}

Há outros aspectos que valem a pena destacar na correlação entre donos e árvores, relacionados ao fato de as árvores servirem de suporte, moradia e fonte de alimento grande parte das aves.

Grosso modo, as aves alimentam-se basicamente de partes dos vegetais como raiz, néctar, frutos, pólen, seiva, algas e sementes; mas há também aquelas que são insetívoras, onívoras, carnívoras, piscívoras e necrófagas. Os Araweté, ao discorrer sobre as aves frugívoras, estabelecem uma associação entre arã ("arara") e munemeti ("gralha") e o atfa'i ("açaí"); totinuhu ("tucano") e mitum ("mutum") à fruta de itiri'i; totinuhu, arã e jaku hu ("jacu grande") ao atfa'i uhu ("bacaba"), entre outras.

Os Araweté distinguem entre aves comestíveis e não comestíveis. Entre as comestíveis estão arã ("arara"), araru ("arara azul"), cadine ("arara amarela"), arã heti ("arara vermelha"), jaku ("jacu") mitum ("mutum"), entre outras. Já as aves não comestíveis são karara (biguatinga - Anhinga Anhinga ${ }^{93}$ ), taperahã ("quero-quero"), arakori ("galinha"), em suma, aquelas criadas por alguém ou que não despertam interesse no consumo como pequenos pássaros e aves necrófagas. Vale dizer que as árvores cujos

\footnotetext{
${ }^{93}$ Para a consulta sobre aves foi usado o Guia de Campo (Sigrist 2008).
} 
frutos são comidos pelas aves que, por sua vez, são consumidas pelos Araweté, tornamse também referência no momento da caça pelo fato de aves pousarem ali para se alimentarem. Certo dia, quando andava em uma capoeira no entorno da casa de Tatua ru com seu filho, Araparawi, e sua esposa, Iwadjma, Tatua ru pediu silêncio a todos, pois acabara de avistar um casal de arara aterrissado em um galho de uma árvore frugívora. Araparawi, se posicionou para atirar, mas errou o alvo.

Além das aves servirem de alimentos, algumas penas são usadas pelos Araweté para produzir artefatos e também como uma espécie de enfeite, e até para sinalização. Assim, penas são utilizadas na confecção de brincos pouco usados atualmente, e, em especial, em festas de peyo ("pajelança"), ou seja, festas com a presença de Mai ou de mortos. Os araweté usam penas azuis de munemeti ("gralha") e penas amarelas da cadine ("arara amarela") para a confecção dos brincos, penugens brancas do peito de kanuhu ("gavião") são coladas no cabelo dos pajés em momentos de festas de peyo e no cabelo dos demais quando os pajés percebem a presença de Ani na aldeia. Nesse caso, também passam urucum no corpo e refugiam-se nas matas. Os sinais diacríticos no corpo marcam assim a diferença entre humanos e não humanos, pois os humanos estão enfeitados e perfumados, em contraposição aos Ani que são fétidos e amedrontadores.

Algumas aves são criadas pelos Araweté, pelos Ani e há aquelas que dizem ser criadas por Mai. Os Araweté criam arara, mutum, filhotes de algumas aves que encontram nas florestas, como gaviões (dos quais retiram as penas) e galinhas. Diversas espécies de aves são criadas pelos Ani e por Mai. Os Araweté comparam esta forma de criar à maneira como eles criam as galinhas, ou seja, soltas no terreiro. Aves criadas pelos não humanos não podem ser comidas e, tampouco, mortas pelos Araweté, pois neste caso estariam sujeitos à flechadas dos Ani ou a algum tipo de represália de Mai, acarretando adoecimentos e mortes. Iwikatiha $\tilde{a}^{94}$, um tipo de Ani, cria taperahã (quero-quero, Vanellus chilenses); Ani cria atodjiã (cigana, Opisthocomus hoazin); ñãwati (martimpescador-verde, Chloroceryle amazona), entre outras. A relação de maestria também é estabelecida entre Mai e um tipo de pássaro denominado pido pido, ajuru ("papagaio") e aradiã (uma espécie de ave parecida com a arara); um interlocutor afirmou ser Mai o dono de taperahã, que na maioria das vezes foi associado aos Ani, como a maioria das

\footnotetext{
94 Iwikatihã é o Senhor das águas. Este tipo de espírito terrestre mora em aldeia e é muito perigoso. Viveiros de Castro (1986:249) indica como seus animais de criação cigarras, trairões e peixes em geral.
} 
aves que indicam ser criadas por um não humano. Enfim não é o caso de enumerar quais aves são criadas pelos Ani ou Mai, mesmo porque não possuo esta lista e diversas associações podem surgir, mas vale destacar que a criação de determinadas aves restringe seu consumo pelos homens e regula, desta forma, o acesso a elas. As aves que não são criadas, por sua vez, não possuem donos; os Araweté consideram que se criam sozinhas nas matas, como os pica-paus, por exemplo, e a estas não há qualquer tipo de controle.

No pedral da aldeia Ta'akati que leva ao rio Xingu, percurso usado para lavar louça, tomar banho e sair de barco, havia um casal de quero-quero com ovos colocados sobre as pedras. Sempre éramos atacados pelos pássaros que protegiam seus ovos, mas ninguém os tratava com agressividade pelo fato de serem criados por Ani. Uma vez, um grupo de meninos, sem qualquer adulto por perto, jogou pedras no ninho e espantou os pássaros quero-quero (Vanellus chilensis) por cerca de dois dias. Todos ficaram preocupados, perguntando se os pássaros haviam morrido e, no limite, à espera do que poderia acontecer. Foi um alívio, apesar de os ataques recorrentes, o retorno dos pássaros.

Para os Awá, os assobios de alguns pássaros alertam para a presença de ajy ou de ha'aera - sombra da pessoa morta que um dia se transformará em ajy. Alguns pássaros são animais de criação dos ajy, como cricrió (Lipaugus vociferans), e o "[...] som do cricrió é dito ser o próprio som dos ajy, e tal pássaro possui a capacidade de se transformar em ajy, tendo em vista que ele mesmo o é. O mesmo ocorre com o canto do pássaro hakawá (acauã - Herpetotheres cahinnans), um canto causador de doenças pois contém ha'aera, se um caçador ouvir seja o acauã (hakawã) ou o cricrió (ajy mitxiurá) enquanto estiver na floresta, pode ser que não encontre caça alguma, pode ser que fique com febre, pode ser que algo ainda pior aconteça [...]". (Garcia 2010:112-113.)

Para os Wajãpi, "as árvores da floresta são concebidas como suporte de praticamente todas as espécies de pássaros, fazendo com que o dono das árvores seja, ao mesmo tempo, o dono das aves, wyra-jar" (Gallois 1988:75). No momento da especiação, Janejar destinou um habitat específico às espécies de pássaros que, naquele momento, foi representado pela sumaumeira - kumaka - de onde se dispersaram e instauraram, cada qual, seu modo de viver. É nesse contexto que certas árvores são identificadas 
pelos Wajãpi como domínios de espécies de aves ${ }^{95}$. Aves vivem em sua morada como os homens e têm a prerrogativa de criar e controlar certas espécies vegetais. Assim, para os Wajãpi, por exemplo, "a domesticação da pupunha é atribuída à coruja Urukurea Tapã'ái. Urukurea Tapã'ãi tem forma humana [...]" (op.cit.:76). O dono das aves controla a reprodução e disponibilidade destas últimas, cabendo aos pajés a negociação para a sua liberação quando solicitado pelos Wajãpi. Os pajés são reconhecidos como grandes especialistas no comportamento das aves, pois elas os auxiliam nas sessões de cura e no processo de comunicação com outros seres.

Para os Araweté, algumas árvores estão associadas à moradia de aves, mas, diferentemente dos Wajãpi, não estabelecem qualquer relação de domínio entre árvores e aves. Os Araweté dizem que kanuhu ("gavião"), reconhecida ave de rapina, instala seu rai ti (ninho; rai - filho de e $t i$ - coletivizador) no juta ’ $i$ ("jatobá"); faz sua casa e instala sua niha ("rede") no juta'i ("jatobá") ${ }^{96}$. Madai ru disse que "kanuhu bota ovo no juta 'i; ele mora no juta ' $i$, é a casa dele, igual a gente". Os Araweté podem nomear o juta' $i$ de kanuhu'i ("pé de gavião"), mas esta relação não anuncia que o gavião é dono do juta'i no sentido de controlar sua disponibilização, apenas evidencia a sua morada. Por outro lado, o fato de totinuhu ("tucano"), arã ("arara") e jaku ("jacu") se alimentarem de frutos de atfa'i uhu ("bacaba") não indica que necessariamente essas árvores sejam suas moradas. Totinuhu e arã podem instalar seus ninhos em ocos de bacabeiras, mas a associação pelos Araweté enquanto morada destas árvores não é tão contundente quanto a morada dos gaviões.

Apesar de haver uma associação direta entre árvores e aves, enquanto suportes e fontes de alimentos, essa ligação, ao menos entre os Araweté, não implica em uma relação de maestria calcada em domínio por parte das aves em relação às árvores. Os donos de aves, sim, mantêm uma relação de controle e cuidado com os seres criados. A presença de árvores associadas a aves desponta como um marcador, cuja relação dependerá das dinâmicas envolvidas em cada contexto etnográfico.

\footnotetext{
95 Árvores entre os Wajãpi também podem ser identificadas a donos (-jara) de animais (Gallois 1988; Oliveira 2006).

${ }^{96}$ A vitória régia (kararawãe) é uma planta aquática que possui folhas redondas muito grandes que ficam sobre a superfície da água. Os Araweté dizem que a sucuri fica deitada na kararawãe; kararawãe é considerada a rede da sucuri (niha).
} 


\section{Princípio vital e gradiente de agência das árvores}

Se mundos ameríndios são regidos pelo multinaturalismo, onde há uma variedade de pontos de vista possíveis para apreendê-los (Viveiros de Castro 1996), e, portanto, estariam saturados de intencionalidades pautadas em relações de alteridade, os princípios agentivos vigoram entre os vegetais, mas, nesse sentido, Viveiros de Castro alerta para o fato de que a "espiritualização das plantas, meteoros ou artefatos [...] parece secundária ou derivada diante da espiritualização dos animais" (op.cit.:119), e indica que esse atributo seria mais evidente em espécies vegetais alucinógenas.

As árvores e outras espécies vegetais apresentam algumas características específicas pelo fato de estarem, em geral, fixadas e, assim, não terem a prerrogativa de circular, a não ser quando partes dos vegetais são carregadas por outros agentes; além disso, as árvores não possuem capacidades explícitas de se comunicar, pois, aparentemente, não produzem som, não falam, não ouvem, como animais e homens. Dessa forma, quais os mecanismos que operam, se é que é evidente e existente, na manifestação do princípio vital e do gradiente de agência das árvores?

Para avançarmos com essa questão, é importante entender a noção de princípio vital para os Araweté que é relacionada à constituição da pessoa. Sendo assim, a pessoa araweté é feita de corpo (s), alma (s) e sombra (s); e, quando morta, em três elementos: o cadáver, o espectro terrestre ( $t a^{\prime} o$ we) e o espírito celeste ( $i$, 'alma') (Viveiros de Castro 1986:494,495,514). O termo $i$ designa "sombra", "imagem", "a essência das coisas", mas também pulsação sanguínea, batimentos vitais do corpo - nesse sentido é expresso como "'princípio-vital-animado', uma vez que os movimentos pulsáteis do corpo vivo são ao mesmo tempo a presença e o índice da presença de $i$ " (op.cit.:514). A noção $i$ designa tanto princípio vital quanto imagem-sombra que são imagens corporais e correspondem, respectivamente, a uma $i$ ativa e uma $i$ passiva; a primeira é gerada com a concepção da criança e possui consciência e percepção (kaaki hã); é presença plena da pessoa, seu "princípio pessoal", e, em sua morte, viajará até o céu (op.cit.:514$517)^{97}$. Após a morte, o período de apodrecimento do cadáver é considerado perigoso pois corresponde ao tempo que o espectro do morto ( $t^{\prime} o$ we), ou seja, a $i$ passiva, vaga

\footnotetext{
97 Para o propósito dessa seção, não cabe avançar na concepção da Pessoa araweté desenvolvido por Viveiros de Castro (1986). Para aprofundamento no tema, consultar os trabalhos do referido autor.
} 
pela terra. O ta'o we é dotado de materialidade e forma humana; é o envoltório de uma sombra, uma sombra materializada; em suma, um duplo do cadáver que vaga pela mata após a morte. Eles aparecem de forma inesperada, assustam os vivos, podem até matar mesmo sem intenção. O ta'o we tem a aparência deformada do morto, mas é um objeto sem sujeito e revela a não presença da pessoa, segundo Viveiros de Castro (op.cit.:498,507). O ta'o we vigora durante o período de apodrecimento do corpo ${ }^{98}$ (hiro) e é companheiro dos Ani. Após esse período extingue-se e libera um outro duplo, os macacos-da-noite que, como o $\operatorname{ta}^{\prime} \mathrm{o}$ we, carregam a marca da impessoalidade. A forma $t a^{\prime} o$ we aplica-se apenas aos espectros dos seres humanos. "Alguns animais também efetuam o - $\underline{a}^{\prime} o$ we. Nesses casos o termo é sempre marcado pelo prefixo $h_{-}{ }^{99}$, entrando em construções genitivas" (op.cit.:510). Animais comestíveis, como veado e anta, e peçonhentos geram $h \underline{a}^{\prime} o$ we - princípio maligno-eficaz dos seres ex-vivos (op.cit.:512) - que devem ter seus espíritos mortos pelos xamãs para evitar danos aos humanos. "Em princípio, todo animal teria um $h \underline{a}^{\prime} o$ we - como tem uma $i$ - princípio vital que se extingue com a morte -; mas isso não é uma teoria muito desenvolvida entre os Araweté" (op.cit.:511). No caso dos vegetais, os Araweté não confirmam a presença de $i$ ou $h \underline{a}^{\prime} o$ we. Araparawi disse-me que "jacaré (jetfere), sucuri (maiahu), veado (arapuha) e anta (tapi'i) têm 'bicho'. Pau não tem 'bicho'. É a mata mesmo que deixa a iwira viva; só vento que derruba a mata. A gente também tem 'bicho' que só sai da gente quando a gente morre. Nosso 'bicho', quando a gente morre, mistura com o Ani que mata a gente ${ }^{100 "}$. Os Araweté dizem, por exemplo, que "pode derrubar a já’i ("castanheira") que não mata a gente"; logo castanheira não tem dono, portanto, não tem Ani e, consequentemente, $-\underline{a}^{\prime} o$ we. Majato ru disse-me também que "pau não tem 'bicho', só gente; ñamo'i ("sumaumeira") não tem 'bicho'". Os Araweté utilizam o termo 'bicho' em substituição ao $t a^{\prime} o$ we. Tiñara du, pajé na aldeia Aradjty, relatou-me que "ta'o we é bicho da gente quando morre. Quando filma tira o ta'o we da gente". Karama ru mostrou-me a projeção de sua sombra no chão diante da incidência dos raios solares

\footnotetext{
${ }^{98}$ Hiro é a forma como corpo é traduzido por Viveiros de Castro (1986:505). Hawutire, no entanto, traduziu-me corpo como "ha'a pe" que significa carne, forma também citada por Viveiros de Castro (op.cit: :496) .

99 "A maneira genérica de se designar "espírito de animal" é $m e \underline{e}$ ráa $o$ we, "espírito de algo" - que contrasta duplamente, por ser flexionável e por "coisificante", com o tá $\underline{\prime}^{\prime}$ we impessoal dos humanos" (Viveiros de Castro 1986:510).

${ }^{100}$ Araparawi disse-me que ninguém come esses animais pelo fato de terem 'bicho'; "'bicho' faz mal para a gente e faz mal para a pessoa que fala besteira na frente dele".
} 
e disse ser similar ao $\operatorname{ta}^{\prime} \mathrm{o}$ we: "ta'o we aparece na mata e vem de noite para a aldeia; $\operatorname{ta}^{\prime} o$ we é de quem já morreu".

Em outros contextos etnográficos, há situações diversas com relação ao princípio vital e agentividade dos vegetais, como veremos. Os Wajãpi concebem que algumas árvores têm pajé, como angelim e sumaumeira, o que, de fato, remete ao entendimento de que "[...] são os donos (-jara) dessas árvores que têm pajé" (Cabral de Oliveira 2012:69). As árvores que têm pajé são perigosas por carregarem um potencial xamânico, condição que faz os Wajãpi evitarem derrubá-las, pois, caso contrário, sofrerão vingança dos donos das árvores que podem atingir o - $\tilde{a}$ (princípio vital) da pessoa. Por outro lado, as árvores que têm pajé - yvyrapaje - são também capazes de curar. Esta categoria de árvores "organiza e regula uma adequação das práticas ordinárias, tais como derrubada da roça, coleta de frutos e palha" (op.cit.:72). Ter pajé (i-paie) remete à "[...] comunicação com o mundo sobrenatural, através de determinados processos de locomoção e acesso às forças xamanísticas; de outro, um conjunto de substâncias e armas, o "pajé" propriamente dito (Gallois 1988:188). Entre os Achuar, para quem as plantas estabelecem relações de sociabilidade similares às humanas, plantas cultivadas possuem "alma" e, consequentemente, uma forma autônoma de existência (Descola 2005:270-272). "Os Achuar da Amazônia Equatoriana, por exemplo, dizem que a maioria das plantas e dos animais possui uma alma (wakan) similar àquela dos humanos, uma faculdade que, ao assegurar-lhes a consciência reflexiva e a intencionalidade, os inclui entre as "pessoas" (aents), torna-os capazes de experimentar emoções e permite-lhes trocar mensagens com seus pares e com membros de outras espécies, e, assim, com os homens" (Descola 1998:25). Entre os Pirahã, quando a morte de uma árvore ocorre em decorrência de uma ação humana, os espectros das árvores se vingam de quem a matou, fazendo-se presentes, durante sessão de xamanismo (Gonçalves 2011:347-348). Para os Jarawara, as plantas cultivadas e selvagens e as árvores ${ }^{101}$ possuem alma, a qual é designada como inamati, que é a forma humana dos seres que saem dos vegetais ou dos animais e vão viver em sociedade, sobretudo no céu segundo Maizza (2013:302). Inamati ${ }^{102}$ é a forma humana dos seres que desprendem-se dos corpos dos vegetais ou dos animais para viver em sociedade no céu (op.cit.:301303). As almas das espécies vegetais estão separadas de sua forma material. Os

\footnotetext{
${ }^{101}$ Essa é a forma com que Maizza (2009:47-51) classifica espécies vegetais.

${ }^{102}$ Espíritos das plantas também são denominados abono (Maizza 2009:49-51; 2014:503-506).
} 
espíritos-das-plantas apresentam intencionalidade consciente, característica que the garante a prerrogativa de sujeito (Maizza 2009:50) e, como as plantas, são divididos de acordo com a sua "força", a qual influencia na forma de preparo e consumo pelos homens (op.cit.:2014:504). Já os Wapishana, como apresentado em seção anterior, identificam uma categoria de plantas wapananinão que possuem alma (udorona), característica que lhes proporciona agentividade e capacidade volitiva. "Donos de vida própria: tal é sua diferença radical com relação às outras categorias botânicas, pois ninguém os cultiva ou cria, mas eles apenas permanecem com quem deles melhor cuidar." (Farage 1998:8). À diferença dos humanos com quem partilham sua alma, característica que lhes confere o atributo da fala expresso pelo canto, os wapananinão nunca morrem. Entre os Yudjá há um relato em que a alma da resina de jatobá provocou a morte de um xamã magnífico (Lima 2005:63).

Como vimos, os Araweté não elaboram enunciados sobre princípio vital e agentividade de vegetais ${ }^{103}$ e, tampouco, identifiquei termos específicos para essas noções, no caso de sua plena efetividade. Temos, então, dois pontos a considerar: i. vigora entre os ameríndios uma variedade de concepções em relação à maestria e as espécies vegetais; e, ii. o princípio agentivo entre as espécies vegetais não é tão evidente e efetivo quanto entre os animais e os humanos.

Descola sublinha que "[...] as cosmologias amazônicas estabelecem uma diferença de grau, não de natureza, entre os homens, as plantas e os animais" (1998:25). Considerando que as características, comportamentos, linguagens ${ }^{104}$, modos de produzir e obter alimentos, atividade sexual, períodos de existência, formas de deslocamento ou de fixação são bem heterogêneas entre humanos, vegetais e animais, não é evidente e, muito menos, consenso entre os ameríndios que vegetais possuam alma, e, portanto, uma capacidade de intencionalidade e agentividade. Nota-se, nesse sentido, uma escala de intencionalidades e agenciamentos, incluindo, no limite, a falta de intenção, mas que por menos expressa que seja, como indicado em algumas situações entre os Araweté, não deixa de estar manifesto um princípio mesmo de vitalidade que deve acomodar as

\footnotetext{
${ }^{103}$ Vale destacar que não houve dedicação especial, por exemplo, ao tabaco, fundamental nas atividades xamânicas, e ao milho usado para a produção do cauim, bebida fermentada em momentos rituais, ou de plantas usadas antídoto ao veneno de cobras, por exemplo.

${ }^{104}$ As almas (wakan) das espécies vegetas, entre os Achuar, por exemplo, estabelecem uma comunicação sem mediação sonora (Descola 1998:25).
} 
variações e recorrências considerando-se os contextos etnográficos e as especificidades das diferentes categorias que abarcam vegetais. Vitalidade seria assim marcada pela capacidade, ainda que potencial, de gerar relações. Assim, de forma mais alargada, para o propósito em questão as noções que gravitam em torno de "alma", "sombra", "princípio vital" podem se aproximar da discussão sobre vitalidade e, consequentemente, dos graus de intencionalidade estabelecidos a partir de pontos de vista de que se existe algo, existe para alguém (Lima 1996:31), situação que marca a possibilidade de existência do princípio relacional (Viveiros de Castro 2002a:118).

\section{Frutos comidos por alguém: aromas como fator de atração}

Um aspecto pouco explorado na etnologia ameríndia quando é abordada a atividade cinegética é a conexão entre animais e vegetais. Mas, afinal, qual seria a relação entre caça e árvores? O conhecimento de frutos que servem de alimento para a caça é um domínio de grande relevância para os ameríndios (Cormier 2005; Cabral de Oliveira 2012). A atividade cinegética está em grande medida atrelada a conhecimentos da dinâmica ecológica. Nesse sentido, uma referência muito marcada com relação às árvores é o fato de produzirem frutos e flores comidos por alguém. A época de florescimento e frutificação das espécies vegetais e o conhecimento dos hábitos dos animais, entre eles os alimentares, são fundamentais para se obter sucesso na caçada.

Sem dúvida, a intenção não é restringir a complexidade da caça ao conhecimento pelos ameríndios de interações entre animais e vegetais ou ao comportamento animal, o que levaria a uma abordagem economicista e funcional. As etnografias têm demonstrado que a caça envolve além de refinados conhecimentos técnicos, relações instituídas entre humanos e não humanos, cuidados com o corpo, aspectos comportamentais, sociológicos e simbólicos ${ }^{105}$. Pretendo tratar, no que segue, apenas de um aspecto relacionado à caça. Procurando focar a abordagem na relação entre animais e vegetais a partir de dados de campo levantados junto aos Araweté e de pistas apresentadas por Cormier (2005) e Oliveira (2012). Entre os múltiplos usos atribuídos às "plantas" pelos Guajá, o domínio mais importante é o alimento dos animais caçados, aspecto que "[...] reflete a importância, para caçadores-coletores nômades, da compreensão do

\footnotetext{
${ }^{105}$ Para aprofundamento sobre o tema da caça, ver Garcia (2010, 2012a, 2012b).
} 
comportamento ecológico de suas presas, o que lhes permite localizá-las na floresta" (Cormier 2005:133). Os Wajãpi, por sua vez, agrupam os vegetais, entre outras possibilidades de classificação, a partir dos hábitos alimentares dos animais, algo que se constitui como um saber imprescindível a um bom caçador. Essa relação pode ser evidenciada nos nomes atribuídos a alguns vegetais, entre os Wajãpi, que podem ser denominados pelo nome de um animal e sua comida vegetal: jãviremi'ốy ("pé de comida de jaboti"), so'oremi'ô'y ("pé de comida de veado") (Cabral de Oliveira 2012:75).

Ao se referir a (ou nomear) determinadas espécies vegetais, os Araweté muitas vezes identificam essas espécies enquanto flores ou frutas comidas por certos animais. Observei esse tipo de enunciado durante uma caçada de jabotis. Os Araweté indicam algumas árvores encontradas nas florestas, cujos frutos ou flores são comidos por jati ("jaboti") e que orientam este tipo de caça: murerawi - conhecida também como bucha, produz fruto que jati come; iwira pidi-i - tipo de pé de bucha, menor que murerawi, produz fruto que jati come; arakatinã - produz fruto similar ao mamão; certa vez, na aldeia Djuruanti, Kuruamaru disse que era "a janta que jati come"; petitini - produz flor amarela comida por jati; akau'i - pé de cacau, produz fruto que jati come; taraikã $i$, pé de tatajuba, produz fruto que jati come; arahu-i, conhecida como gulosa ou frutão, produz fruto que jati ("jaboti") e tajahu ("queixada") gostam; moro e katiniwã, frutos comidos por jati, entre outros. A seguir indico outros exemplos de árvores encontradas principalmente nas florestas cujos frutos, principalmente, ou flores são comidos por alguém: kararuhu ("paca") come flor ñapukai ("sapucaia"), manga, awatfi ("milho"); arã ("arara"106 ) come inadja ("inajá"), atfa’i ("açaí") e ni ("castanha"); akaña ("cajá") é comido por jati, tapi'i ("anta"), paca, atfitfi ("guariba") e jaku ("jacu"); iwiriti ("matamata") é comido por kararuhu ("paca"), arapuhã ("veado"), tapi'i ("anta") e taitetu ("cateto"); iwira pidi, como citado anteriormente, produz fruto que é comido, além do jaboti, por tapi'i, arapuhã, atfitfi, mico (uma espécie de macaco da noite) e juparã (outra espécie de macaco da noite); juara'i ("tucum"), produz fruto comido por ipaku branco ("pacu"). Namu'i ("sumaúma") é muito grande, fica na beira do parani' iwe ("margem do rio") e na ka'aiwe ("mata") e "só ipaku come seu fruto", disse Kuruamaru.

\footnotetext{
${ }^{106}$ Há mais de uma espécie de arara: arã hete - arara vermelha; hete significa verdadeiro, araru - arara azul, cadiné - arara amarela.
} 
Enfim, pude registrar, em campo, uma extensa relação de frutos e flores consumidos por diversos animais. No entanto, esses registros mostram que nem tudo é comido por $\operatorname{todos}^{107}$. Há a expressa indicação de frutos que não devem ser comidos pelos homens como, por exemplo, moro, juara e frutos comestíveis como akanã ("cajá"), akau ("cacau"), arakatinã e juta'i, para citar alguns. Também indicam frutos que não são comidos por alguns animais, como, por exemplo, atfitfi ("guariba") que não come arahu, fruto comido pelos humanos. O conhecimento da dinâmica de quem come o quê, atrelado aos hábitos dos animais, é fundamental para direcionar a circulação pelas florestas. Por estarem fixadas, as árvores tornam-se importantes marcadores no território a partir da cadeia trófica. A presença de determinadas árvores e a relação de predação empreendida por animais que se alimentam de frutos e flores indicam lugares por onde eles circulam. As árvores cujos frutos e flores são comidas por alguém revelam-se índices fundamentais no estabelecimento de relações com alguns animais e, consequentemente, entre homens e determinados animais e também entre homens e árvores. A época de frutificação, em geral, ocorre no período das chuvas, sendo menos abundante no período mais seco. Este também é um fator que colabora na orientação da circulação pelas florestas e indica a predominância da caça de certos animais em determinados períodos. $\mathrm{Na}$ "caça de espera" os Araweté aguardam na árvore que produz frutos comidos pela caça de interesse, como quando Juruawi du caçou duas cotias ao esperar na árvore makuré que produz fruto que cotia come e Iwane ru para caçar pacas à noite, esperou na ñapuka'i poti ("flor de sapucaia") que produz flor que paca gosta de comer. Dessa forma, a caça de jabotis, por exemplo, é orientada pelas árvores que produzem frutos que jaboti gosta de comer; quando os Araweté saem para caçar jabotis orientam-se pelas árvores que produzem frutos que jaboti come - essa atividade será detalhada no capítulo III, em uma seção específica.

Ser comida de alguém, no caso de frutos e flores, envolve a percepção dos Araweté sobre as árvores e as relações a elas associadas e, aqui, focarei em fatores que optei por chamar de "atração". Os sentidos configuram-se elementos perceptivos e operadores relacionais. Entre os Guajá plantas aromáticas são usadas em processos curativos e "[...] plantas odoríferas repelem os aiyã, fantasmas dos mortos, que se acredita causarem

\footnotetext{
${ }^{107}$ No pensamento makuna todas as formas de vida têm uma forma material e outra imaterial, que pode ser vista pelos xamãs ou quando do uso de alucinógenos, e todas essas formas são classificadas, seja como comida, seja como comedor (Arhem 1993).
} 
doenças ao penetrar o corpo com seu odor fétido, canibalizando então a alma da vítima." (Cormier 2005:131). A potência do aroma tem a capacidade de criar e transformar as forças vitais de uma pessoa como entre os Piaroa, para quem, o cheiro gostoso de uma comida é capaz de gerar a "força da beleza" (Overing 2006:45). O aroma como fator de atração, bem como de repulsão, pode auxiliar no entendimento de como os ameríndios, no caso, lidam com os aspectos físicos, sistemas de significados, dinâmicas ecológicas e sociais em diferentes contextos etnográficos. Aqui podemos nos espelhar no procedimento recomendado por Lévi-Strauss "[...] não para destacar universais cognitivos, mas para explicar a maneira como o espírito procede em contextos culturais e geográficos distintos, sofrendo em seu funcionamento o efeito de atração e de desvio que as peculiaridades e o ambiente físico e social lhe impõem." (Descola 2011b:37).

Os Araweté reconhecem os frutos que os animais gostam de comer e esta observação vai muito além do interesse pela caça. $\mathrm{Na}$ perspectiva araweté, mais que um componente alimentar, o gosto aparece como fator de atração dos animais por certos frutos e flores: "taitetu ('cateto') e tajahu ('queixada') gostam de comer madja ('macaxeira')"; "tajahu gosta de gulosa, pati'iwã e ka'ana e fica gordo quando tem os frutos". Foi-me explicado que queixada gosta de frutos assim como gado gosta de pasto, quando este estava comendo madja na roça de Nana hi, no Ta'akati. No Djuruanti, por exemplo, foram caçar jaboti onde tem gulosa, "fruto que jaboti gosta de comer". O paladar é essencial na seleção dos frutos comidos pelos animais e aparece como uma forma de expressar o gosto e a atração entre animais e árvores.

O cheiro exalado pelos frutos, flores e cascas é fator preponderante para a atração dos animais. Durante uma caminhada na ka'ape ("capoeira") de Tatua ru, situada nas imediações de sua casa, Iwajma, sua nora, mostrou-me o fruto de murerawi, "fruto que jati come". Iwajma, que então estava à minha frente seguindo seu marido, Araparawi, coletou o fruto no chão, cheirou-o e ofereceu para eu cheirar também.

Kuruama ru, da aldeia Djuruanti, relatou-me sobre os frutos que jaboti come: "Iwãkat $i$, fruto que jaboti come é igual à maçã, só jaboti come. Iwãkatfi fica embaixo do ihipa, tipo de cipó. Iwãkat é hewu me'e ('cheiroso'); é cheiroso igual itiri'i hi (resina cheirosa que é misturada ao urucum para perfumar o corpo). Jati ('jaboti’) fica cheirando e vai 
atrás. Ele procura até encontrar. Jati fica procurando onde está cheirando. O fruto fica embaixo, seu pé sobe no pé de pau. É parecido com cheiro de padidi ('banana'); é hewu me'e ('cheiroso')". Ele também conta que "muru, outro fruto que jati come, é hewu me'e. O pé dele, muru'i, é igual juara'i ('tucum'), mas é diferente (é um tipo de palmeira). Só jati come, é hewu me'e; jati cheira e fica embaixo. Muru'i fica no mato. Taraikã é hewu me'e, é fruto que jati come, só jati come. Pé dele é taraikã'i. He xã ('procura') primeiro taraikã'i para pegar jati, então vai atrás, faz caminho". Ao ser indagado se muru'i, no caso, tinha dono, disse-me prontamente que não.

Ao salientar outro sentido, a visão, Kuruama hi, além de indicar, que ela é fundamental para a caça de jaboti quando procuram pelas árvores cujos frutos são comidos por jabotis, não deixa de marcar que a cor dos frutos também aparece como elemento de atração ao apontar que arakatinã, fruto vermelho semelhante ao mamão pequeno, é comido por jati (“jaboti”), kararuhu (“paca”), tatu, akoti “(cotia”) e pelos homens.

Os sentidos, além de realçar qualidades dos seres e das coisas, são modos de perceber e conhecer que exprimem conexões e relações estabelecidas a partir de características sensoriais enfatizadas pelos ameríndios. Não se trata da primazia de determinado sentido, mas da importância que é dada aos diferentes sentidos e aos valores e códigos sociais que estão atrelados, conforme defende Classen (1990, 1997). "Cada uno de los sentidos puede estar vinculado a distintas series de asociaciones y se puede conceder más valor a unos que a otros" Classen (1997:1), como demonstra abaixo:

"While the Suya do not focus on sight to the same extent as the Desana, they do place a considerable emphasis on smell. As among the Desana, people, animals, and plants are classified according to their odors. In general, strong odors are associated with nature and bland odors with culture [...] One's odor can also vary according to one's position in the community and one's age [...] The Suya thus use odor classes not only to categorize species and tribes, as do the Desana, but also to represent social classes...The Bororo, another people of central Brazil, have an equally elaborate classificatory system of odors [...]" (Classen 1990:729-730).

Nesse sentido, as associações que os Araweté estabelecem ao definirem as relações entre animais e vegetais a partir dos frutos comidos por alguém, fundam-se em uma 
estética do belo - pelas cores vibrantes -, no aroma e sabor agradáveis. No outro extremo, poderíamos colocar os odores fétidos como fator de repulsão, conforme ressaltam em relação aos Ani e ao ta'owe - não aprofundei esse entendimento com relação aos vegetais. Essa associação entre animais e vegetais, relação que não deixa de ser de predação, não implica, em geral, na morte ou extermínio de um dos termos da relação ${ }^{108}$.

Vale ainda notar que os Araweté no caso das relações estabelecidas entre animais e vegetais atribuem aos animais a percepção dos atributos sensoriais destacados como preponderantes. Jati (“jaboti”), kararuhu (“paca”) e outros animais sentem cheiros agradáveis, visualizam cores vibrantes e apreciam o que comem e, por isso, são atraídos por determinados frutos e flores.

Aqui, adequo para a relação entre animais e vegetais a análise empreendida por Eduardo Kohn $(2002,2007)$ no que denomina "antropologia da vida" a partir das interações entre os Ávila Runa, habitantes da Amazônia equatoriana, e os animais em que enfatiza as capacidades semióticas de todos os seres vivos. Nesse sentido, o engajamento prático revela assim percepções estéticas e experiências sinestésicas que direcionam as associações estabelecidas entre os seres. Se animais são atraídos por cores vibrantes, odores e sabores, na maioria, agradáveis, segundo os Araweté, vegetais, por sua vez, exalam cheiros fortes e apresentam diferentes tonalidades de cores e formas para atrair animais polinizadores e dispersores de sementes. Todos os seres envolvidos nessa rede de relações produzem efeitos nas conexões estabelecidas que repercute, como em cascata, em outros elos das cadeias relacionais gerando reações e combinações. Seres posicionados de forma assimétrica se combinam e levam à perpetuação de seres, até certo ponto, e a diferentes formas de predação estabelecidas na relação entre animais e vegetais, entre homens e vegetais e entre homens, animais e vegetais.

\footnotetext{
108 Inclusive, do ponto de vista ecológico, muitas destas interações colaboram para a reprodução e perpetuação das espécies vegetais através da dispersão de sementes e da polinização das plantas. Antas, macacos, jabotis, paca ao comerem frutos de certas árvores contribuem com a dispersão de suas sementes; abelhas, formigas, besouros, borboletas são responsáveis pela transferência de pólen entre as flores o que proporciona sua fecundação.
} 


\section{Árvores e méis}

De praticamente todos os lugares da aldeia Ta'akati avista-se uma grande e imponente ñamu'i ("sumaumeira"). Eu estava na casa de Madai ru, um dos melhores e mais assíduos caçadores da aldeia, e, durante uma conversa, indaguei se alguém morava na ñamu'i. Madai ru disse: "Ninguém, só iwahu ('mel')". Apontou então uma grande colmeia assentada em um galho da majestosa ñamu'i.

Os homens araweté coletam o mel ${ }^{109}$ no verão, a partir do mês de setembro. Em outubro de 2012, durante uma derrubada de mata - etapa de preparação da roça -, nas imediações da aldeia Djuruanti, uma árvore com uma colmeia foi derrubada e o dono da roça a ofereceu às mulheres e crianças. Dispusemo-nos agachadas em volta do favo; para degustá-lo, raspamos o mel com as pontas dos dedos levando-o à boca ${ }^{110}$. Os Araweté denominam esse mel de eduan e afirmam que o mesmo pode ser encontrado nas árvores ñamuru'i, jata'i e iwira'i e que é apropriado para grávidas e bebês. Kunirikuti, jovem recém-casada moradora da aldeia Djuruanti, disse-me que mel (e) eduan é hewu hete me'e, doce, e por ser muito doce (he'e) os homens não podem comer.

O mel é obtido pelos homens pela derrubada das árvores onde estão as colmeias e é comido cru (wi). O mel, como a carne, é alimento considerado pelos Araweté cewe ("gorduroso"). Carne e mel representam a oposição entre caça e coleta no contexto de vida na mata, sendo os homens os responsáveis pela caça e as mulheres, em geral, pela coleta. Embora o mel seja coletado pelos homens, eles o fazem para as mulheres "[...] que o consomem em primeiro lugar - ao contrário da carne, consumida primeiro pelos homens" (op.cit.:273). A vida araweté nas matas é representada por Viveiros de Castro pela equação: (Homem:Mulher) :: (Caca:Coleta) :: (Carne:Mel)" (op.cit.: 273).

Em Do mel às cinzas, Lévi-Strauss (2004) estabelece uma contraposição entre o mel e o

\footnotetext{
${ }^{109}$ Alerta-nos Lévi-Strauss "os índios sul-americanos que encontram mel sobretudo em ocos de árvores, onde várias espécies de abelhas fazem seus ninhos, o classificam por este motivo no reino vegetal" (2004:31-32). Para os Araweté, Viveiros de Castro indica que o mel "parece ser uma categoria única" (1986:351) e, portanto, não é classificado na categoria dos vegetais.

${ }^{110}$ Entre os Araweté o mel é consumido, em geral, no momento da coleta, como eu pude vivenciar e, também, conforme afirma Viveiros de Castro (1986:353) ao acompanhar uma coleta de mel. Assim também fazem os Awá: "ao irem extrair mel, os Awá dizem "comer mel" (haíra u'ú) e não "coletar mel" (haíra py), uma vez que boa parte dele é consumido no próprio ato de coleta, enquanto que o restante (quando há) é levado à aldeia" (Garcia 2010:54).
} 
tabaco. Nos mitos, o mel coloca o perigo de a humanidade perder as aquisições culturais e assim se reaproximar do estado de natureza, ao passo que o tabaco estabelece a relação com os não humanos. "O mel, alimento dado pela natureza, está aquém da cozinha, ou seja, não se submete a qualquer mediação, ao passo que o tabaco, que deve ser consumido pelo fogo, situa-se além da cozinha. Se o mel representa, nos mitos, a emergência da natureza na cultura e é largamente associado à sedução e ao envenenamento, atos que implicam o perigo de regressão à natureza, o tabaco designa a manifestação da cultura no próprio seio da natureza e anuncia uma necessidade de mediação, de restabelecimento do contato perdido com o outro mundo." (Sztutman 2005:215).

Os méis, como vimos até aqui, são uma categoria de "alimento" muito relevante entre os ameríndios que assume diversas significações, como também indicado em etnografia awá "[...] o mel se apresenta aos Awá, não somente como um alimento poderoso (física e mentalmente), mas como um componente que articula aspectos importantes da vida: saúde e doença; emoções (o mel doce é capaz de dissipar a tristeza) e afecções diversas (como o prazer sexual); um alimento importante, que provoca uma felicidade vital" (Garcia 2010:236).

Para os Araweté, o mel quando ingerido provoca amolecimento, sintoma semelhante ao de uma relação sexual. "O caráter melífluo do sexo se evidencia de maneira "crua" na tradição jocosa Araweté, onde nomes de espécies de mel são usados como metáforas do "gosto" de cada vagina da aldeia, e como sinédoque de cada mulher [...]" (Viveiros de Castro 1986:352). A relação entre mel e sexo, entre mel e sedução e entre o mel e doce é profícua entre os ameríndios como apresentado nos mitos por Lévi-Strauss (2004); para os Awá, "sexo é dito ser he'e, cuja tradução é "doce", da mesma forma que o mel (hairra) é doce, em oposição ao azedo (irawahy) (Garcia 2010:195); os Araweté também dizem que "o mel é doce como a vagina" (Viveiros de Castro 1986:351), apesar de estar na categoria cewe (gorduroso). Mas o mel enquanto instrumento de sedução "[...] contém um perigo de reversão a um estado contínuo, de regressão à natureza" (Sztutman 2009:302).

O mel também é consumido por seres que vivem no patamar celeste, como os karawara, entre os Awá, que descem à terra para caçar e extrair mel e retornam ao céu 
para consumi-lo (Garcia 2010:240,396) e os Mai, que o consomem de forma ritual quando o mel lhes é ofertado após ser coletado pelos humanos. Esse seria o xamanismo (peyo) do mel, que pode ser consumido puro ou misturado ao açaí, e que ocorre a partir de setembro, quando há a disponibilidade desses produtos (Viveiros de Castro 1986:269,355). Majato ru disse-me que iria organizar uma festa do mel a perdido de Mai que, no entanto, deveria autorizá-lo, não por ser o dono do mel - pois não o é -, mas por esse alimento conter potência xamânica, isto é, "flechas" capazes de ferir a boca - tema que será abordado no capítulo III. Para explicar-me essa situação, Majato ru fez uma analogia à autorização emitida pela FUNAI (Fundação Nacional do Índio) para a minha entrada em Terra Indígena como pesquisadora.

Para os Araweté, o mel associa-se aos Ayaraetãa, que são manifestações do próprio mel, particularmente do mel de xupé, mas não são considerados "donos dos méis". Esses seres visitam os viventes na estação seca e partem no início da estação chuvosa, quando acaba a produção do mel. Os Ayaraetã vagueiam pelas matas e oferecem perigo mortal principalmente às mulheres; o mel é relacionado ao sêmen quando associado aos Ayaraetãa, contexto que reforça a relação entre mel e sexo. "[...] caso encontremos um desses seres na floresta, durante uma expedição de coleta de mel, devemos dar o produto a ele, senão ele nos mata." (Viveiros de Castro 1986:248).

Os Araweté identificam uma diversidade de tipos de méis que são, em grande medida, relacionados a certos animais e paladares. As árvores, por sua vez, são associadas a suportes de méis. Akoti e, mel doce de cotia, fica na kumani'i ("árvore grande sem dono"), mas pode ser encontrado em qualquer árvore; atfitfi e ("mel doce, mel de guariba"), fica no iñopo'i (“angelim”), dizem também que ninguém mora no angelim; arapuhã e ("mel de veado") considerado i'da me'e ("azedo") e fica em pau podre, na $j a$ 'i ("castanheira"), ou em qualquer tipo de árvore; pidi iwahu ("mel vermelho"), fica na árvore pidi iwahu'i; iwahu poin é hewu me'e (mel poin é doce), menino novo e mulheres grávidas não comem, faz mal, deixa magro; iwaho hete ("mel verdadeiro)" menino novo come, fica no juta'i (“jatobá") e é hewu me'e ("doce"); diti e ("tipo de mel”) e é hewu me'e (“doce"); irã e ("mel pequeno"), fica dentro do cipó podre; alguns tipos de méis ficam também na ñapuka'i (“sapucaia”), ñuta'i (“jutaí”) e em diversos tipos de pau; mel chamdo xupé é encontrado em grandes colmeias localizadas em já’i 
(“castanheira”) e juta'i (“jatobá”)"11. "Há méis venenosos e eméticos, como "mel dos "Aní"; outros fazem cair nossos cabelos, como o "mel de saúva", e tem aqueles que os eriçam, como o "mel do quati"; outros fazem o feto se agitar na barriga da mãe e despertam a fecundidade masculina, como o "mel do fogo"'" (Viveiros de Castro 1986:353). Entre os Araweté, nem as árvores, nem os animais são apontados como donos de méis. Entre os Awá, méis e animais ${ }^{112}$ mantêm "relação do tipo rikô, onde um está junto associado ao outro" (Garcia 2010:241. Grifos do autor), estando abelha e mel associados à jara animal, mas sem estabelecer relação de controle.

Apesar de escassos, meus dados de campo a esse respeito sugerem que os méis estão inseridos em classificações construídas a partir da lógica das qualidades sensíveis. Os méis estão também associados às árvores, aos animais, além de apresentarem diversas propriedades e correlações como mencionadas acima. Há uma estreita relação entre méis doces e azedos, permissões e proibições alimentares, sedução e interditos e evidente associação com a sexualidade que instauram códigos que revelam a ambiguidade e a relevância do mel. Assim, o ponto a destacar, ao menos no que diz respeito à discussão proposta nesse capítulo, é a percepção da relação entre árvores e méis. As árvores, por serem suportes de grande parte das colmeias, são percebidas como "moradias" dos méis. Nessa associação não há, no entanto, uma relação de posse ou interdito, mas, dada a proeminência dos méis, ao associa-los a árvores, ficam marcadas descontinuidades e posições em meio às florestas e indicadas possibilidades de instauração de socialidades.

\section{Marcas concretas: dureza e grandeza}

Como procuro evidenciar, a partir de etnografias tupi, prioritariamente, vegetais - e em especial, as árvores - apresentam diversas características que as diferenciam dos animais e dos humanos. Muito além de uma relação entre presa e predador, as relações entre vegetais e humanos desencadeiam múltiplas relações e associações que podem variar em grau e natureza. Nesse sentido, Bloch (2001:42) menciona como elemento

\footnotetext{
111 Viveiros de Castro indica ao menos 45 tipos de méis entre os Araweté, entre comestíveis e não comestíveis (1986:158).

112 Garcia faz uma análise dos mitos apresentados em "Do Mel às Cinzas" (Lévi-Strauss 2004) que estabelecem a origem do mel aos animais que detinham seu controle e, então, associa méis e animais a partir da relação rikô (2010:237-242), apresentada na seção sobre 'Reprodução e crescimento dos vegetais'.
} 
fundamental na comparação entre vegetais e humanos a ênfase na dureza característica que permite a transformação das árvores para usos diversos, como será apresentado na seção seguinte - e durabilidade ${ }^{113}$ das árvores, como apontado pelos Zafimaniry. Portanto, qualidades sensíveis como dureza, grandeza e durabilidade das árvores são características de extrema relevância quando são analisadas vegetais a partir de perspectivas ameríndias.

Oliveira (2012:35) ressalta que a dureza dos troncos é apreendida pelos Wajãpi na prática, durante a derrubada de árvores para plantio de roça, quando os jovens constatam a dureza do tronco de uma árvore e, diante disso, decidem mantê-la em pé. De acordo com Oliveira, a oposição entre troncos duros e troncos que não são duros marca uma categoria concreta na identificação de árvores. Entre os Araweté, também em uma situação de derrubada de árvores para plantio de roça, constatei que a forma como derrubam a mata fornece pistas sobre aspectos sensíveis atrelados às árvores que inclusive são indicações sobre modos araweté de conhecer e se relacionar com as árvores e florestas. Jovens do sexo masculino são incumbidos de desbastar a mata com facão; a eles também são reservadas árvores mais finas e menos duras, quando são orientados pelos mais velhos sobre direção e posição de corte. Os homens adultos se encarregam das árvores mais grossas e duras (hatin me'e) e conduzem o movimento da derrubada. Também me relataram que os jovens não derrubam já'i ("castanheira"), tarefa reservada aos homens maduros. Na derrubada a que assisti, esta foi a última árvore a ser abatida, muito provavelmente por causa de seu grande porte e dureza do tronco, característica que, nessa circunstância, organiza a dinâmica do trabalho entre homens mais jovens e mais velhos. Quase todos da aldeia Djuruanti estavam envolvidos na atividade de derrubada da mata para o plantio da roça. Diversas famílias montaram acampamento no local escolhido, onde instalaram redes para descanso, cozinharam, teceram, crianças brincaram, mulheres buscaram água na cacimba e assim passamos o dia enquanto os homens se dedicavam à derrubada de uma área de mata.

Dureza e durabilidade também são avaliadas quando a madeira é usada para produção de artefatos como, por exemplo, no caso de construção de canoa usam a taraika'i

\footnotetext{
${ }^{113}$ Aspectos como dureza e durabilidade dos troncos das árvores foram relacionados à dinâmica social conforme abordado por Rival (1993) entre os Huaroni e apresentados na seção sobre reprodução e crescimento de vegetais.
} 
("tatajubeira") pelo fato dessa madeira apresentar essas características. Iwanero, ao quebrar um coco de babaçu com facão para extrair a castanha e oferecê-lo às crianças, assinala sua dureza como qualidade essencial dado o esforço empreendido na atividade. Os troncos do ipê, usado para fazer arco, e do jatobá (juta'i), que pode ser usado para lenha, também são caracterizados como hatin me'e ("duros"). Em contraposição ao duro está a categoria itume (mole) - como o tronco de aranini, pau considerado mole (itume) pelos Araweté e usado apenas para fazer fogo. Essa categoria sensível do "mole" é frequentemente associada a do "podre", nas mitologias ameríndias, como mostra LéviStrauss em suas análises dos mitos da vida breve e da origem do fogo (1991:150;73-75), a partir das quais estabelece uma série de transformações das oposições: madeira dura / madeira podre e madeira viva / madeira morta. A exemplo do mito apinajé (M9), podem ser citadas inúmeras variantes do mito entre outros povos, em que, o herói, ao invés de seguir o conselho da onça e ouvir apenas o chamado da rocha e da madeira dura, ouve o chamado da madeira podre e, assim, encurta a vida humana. A vida breve está também ligada à origem da culinária, dado que para acender o fogo necessita de madeira morta; cozinhar é, então, "[...] "ouvir o chamado da madeira podre". Há mais: a vida civilizada requer não apenas o fogo, mas também as plantas cultivadas que esse mesmo fogo permite cozinhar" (op.cit.:151). Para fazer o roçado é necessário queimar a madeira viva a fim de limpar o terreno para o plantio; assim, a morte é introduzida. É interessante observar que tanto no caso wajãpi quanto araweté na derrubada da roça se faz absolutamente presente o tema da madeira dura, seja mantendo-a em pé ou derrubandoa por último, fato que não cheguei a presenciar entre os Araweté no caso citado da castanheira. Após a derrubada da mata, queima-se o material orgânico depositado no terreno, última atividade realizada antes do plantio. Portanto, dureza e durabilidade são operações que caminham juntas nas associações entre vegetais e humanos, características que orientam a realização de algumas atividades.

Os Araweté ao descreverem algumas árvores também ressaltam sua grandeza. Kuruama ru falou que a ñamu'i ("sumaumeira") fica no parani we (no rio; na margem do rio) e é huwiha ("grande"); juta'i (“jatobá”) é huwiha; e, taraika'i ("tatajubeira”), árvore que produz fruto que jaboti come, é iwira huwiha (“árvore grande”). Quando o tronco fica grosso falam huwiha uhu. Em oposição, descrevem algumas árvores como iwira $i$ 
("árvore pequena"114), como é o caso da iriwa pidi, que produz fruto vermelho, e da para'i que produz frutos que jaboti come. A grandeza e o destaque de algumas árvores pelo seu porte são salientados pelos Wajãpi ao mencionarem a sumaúma ou o angelim e a elas se referirem como árvores chefe, como protótipo da espécie ou protótipo cognitivo da categoria árvore, dada essas características, ou seja, o destaque de algumas dimensões sensíveis extremas (Cabral de Oliveira 2012:62-67).

Características táteis e visuais apreendidas na prática funcionam como operadores lógicos que marcam saberes constituídos sobre árvores e, de uma forma mais ampla, sobre vegetais; além de que, qualidades sensíveis retidas como proeminentes são peculiares de modos ameríndios de conhecer por tornarem algumas espécies referências, instaurarem descontinuidades e marcadores relacionais. Além disso, determinadas características atribuídas às árvores, como assinalado, colaboram com a produção de relações e socialidades.

\section{Transformações das árvores pelos usos}

Outra interessante problemática relaciona-se ao modo como são pensadas e efetivadas, entre os ameríndios, as múltiplas transformações dos vegetais, seja de suas partes ou do todo para produção de artefatos, fogo e alimentos, para a cura de enfermidades ou para provocar doenças, para a construção de casas, confecção de armas, produção de cestarias, tinturas, entre outras utilidades (Lévi-Strauss 1987:29-46; Albert, Milliken \& Gomez 2009).

Essa questão remete inclusive ao debate entre abordagens ditas "idealistas" e "materialistas" (Hunn 1982:833; Lévi-Strauss 1986:150). De sua parte, Hunn (1982:833) afirma que taxionomias nativas estão calcadas em distinções "naturalmente" úteis dada a importância do significado prático no processo classificatório. Propriedades utilitárias das árvores são, muitas vezes, mais salientes do que características morfológicas na elaboração perceptual (Elle, R. apud Brown. C.H. 1990:31-32 ${ }^{115}$ ). Essa situação, mas não apenas ela, foi observada entre os Nalu, que distinguem árvores ( $n$ 'ti)

\footnotetext{
${ }^{114} \mathrm{O}$ uso do morfema $i$ depois de vogal nasal final indica atenuação com relação a propriedades físicas ou emocionais (Solano 2009:144).

${ }^{115}$ BROWN. C.H. "A survey of category types in natural languages:. In: S.L.Tsohatzidis (ed.). Meaning and prototypes: studies in linguistic categorization, London and New York: Routledge. 1990.
} 
de lianas (manar) pelo fato das árvores crescerem verticalmente, serem fixas e estáveis e as lianas serem flexíveis. $\mathrm{O}$ aspecto morfológico assume papel importante nesta diferenciação, mas, como enfatiza Frazão (2001:142), "[...] noutras circunstâncias, a identificação de manar é também realizada através dum critério utilitário. Os indivíduos distinguem as lianas das árvores ou das ervas pelo facto de se poderem usar os seus caules como cordas". O fato é que elementos empíricos e utilitários são aspectos relevantes na percepção dos humanos sobre vegetais, além de manifesta dependência dos homens em relação aos vegetais (Bloch 2001:42) para a construção de casas, alimentação, enfim, em quase todos aspectos da vida. Nesse ponto vale mencionar observação feita por Lévi-Strauss de que os indígenas não nomeiam e conceituam as coisas apenas em decorrência de suas necessidades. Os elementos empíricos, históricos e as características ambientais se ajustam a aspectos mentais e constituem conjuntos significantes (Lévi-Strauss 1986:151-152). A atenção está no pressuposto, com relação "à ciência indígena", de que "[...] seu objeto primeiro não é de ordem prática. Ela antes corresponde a exigências intelectuais ao invés de satisfazer às necessidades" (2005:24). Disto decorre a célebre conclusão "[...] que as espécies animais e vegetais não são conhecidas porque são úteis; elas são consideradas úteis ou interessantes porque são primeiro conhecidas" (op.cit.:24).

Assim, no processo de transformação de vegetais para usos diversos, são consideradas qualidades sensíveis, aspectos utilitários e sistemas de significados. Para fazer arco, flecha e canoa, por exemplo, é necessário um tipo de madeira dotado de qualidades específicas. "Em todas as regiões da América do Sul usam-se umas poucas madeiras específicas para a confecção dos arcos, aquelas que a experiência demonstrou terem resistência e força adequadas: entre os Ona e Yahgan, de faia (Nothofagus antartica); entre os grupos do Chaco, principalmente de palo mataco (Achatocarpus praecox), mas também Prosopis abbreviata, quebracho (Schinopsis lorentzii) e muiraquatiara (Astronium junglandifolium); no leste do Brasil e no alto Amazonas, de palmeira pupunha (Guilielma gasipaes). No leste do Brasil, o Astrocaryum ayri era tão amplamente utilizado para arcos que seu nome comum é pau d’arco" (Métraux 1987:140). A construção de uma canoa requer a escolha do material adequado, ou seja, do tipo de tronco que será transformado em canoa para que a mesma não afunde. Esta escolha envolve características como resistência à água, durabilidade e porte do tronco no caso da canoa ser construída a partir de uma única peça, além de aspectos que vão 
além das qualidades sensíveis. Sem dúvida, não são apenas essas características que contribuem para o sucesso da empreitada. As habilidades e os saberes dos construtores, a época do ano e outros aspectos são determinantes na arte de construir canoas. Durante minha primeira estada na aldeia Ta'akati, Iwane ru estava organizando a construção de uma canoa. A busca por uma árvore lenhosa, com tronco duro e resistente, características fundamentas para a eficácia e a durabilidade de uma canoa, determinou a árvore a ser escolhida - traika'í ou "tatajuba" - e o local onde seria construída a canoa. As mulheres tratavam de estender as redes, limpar a área onde o fogo seria aceso e, algumas vezes, instalar o suporte para tecer a saia. Os homens serravam, cavavam e esculpiam, com motosserra e facão, o tronco de taraika'i ("tatajubeira") que, aos poucos, era transformado em canoa. Privilegiam a madeira dura, grande (huwiha uhu) e, acima de tudo, durável. Quando uma menina se sentou sobre o tronco da taraika'i ("tatajubeira"), sua mãe logo a advertiu. Mulheres não podem sentar no tronco da canoa em construção, caso contrário corre-se o risco do tronco rachar ${ }^{116}$.

Entre os Araweté, de casca de petin niro enrola-se o fumo; de apikawi ("mogno") e de akaña'i ("pé de cajá"), esculpe-se remo; de itiri'i, extrai-se resina cheirosa; de tadipã (“ipê”), confeccionam arco; de iñopoko'i (“angelim”), também constroem canoas; de nata'i ("pé de babaçu"), come-se a amêndoa, da palha, cobrem as casas, do talo, fazem suporte para o tear e armadilha para peixes denominada hara; de ja'i ("castanheira"), usam o tronco para a construção de casas e suas amêndoas como alimento; de kure'i fazem flecha e caniço; do iriku ("urucum") usam o fruto para a produção de tinta, para assadura de bebê; da pati i (paxiúba - Socratea exorrhiza), palmeira de tronco fino com raízes aéreas repletas de espinhos eram usadas as raízes para ralar mandioca para a produção do beiju - hoje esse uso foi substituído por artefato industrializado -; enfim, essas são apenas algumas indicações da polivalência dos vegetais; fora a parte alimentar que provê tanto humanos quanto animais. De cipós os Araweté usam a fibra do caule para produzir corda para amarrar caça, casa, entre outras coisas; ingerem a seiva para tratar problemas digestivos e intestinais e extraem veneno que será usado em pescaria. Partes de vegetais também são usadas em curas de doenças ou para estimular alguma habilidade, tema que será tratado no capítulo III. Mas não é apenas aos humanos que

\footnotetext{
${ }^{116}$ Ainda que de forma preliminar, por carecer de mais dados, pode ser que também seja estabelecida alguma analogia entre o formato das partes íntimas femininas ao fato de se temer que a madeira rache, mas não posso assegurar que seja este o entendimento dos Araweté, o que pode evidenciar que nem somente aspectos práticos são considerados na transformação e uso dos vegetais.
} 
são reservados os usos e saberes atrelados aos vegetais. Na descida do pedral a partir da aldeia Ta`akati, em sentido ao rio Xingu, há uma espécie de bromélia que é denominada pelos Araweté Ani kurawa. As fibras dessa bromélia são usadas tanto pelos humanos quanto pelos Ani para fazer arco. Karama ru disse-me que Ani usa esse arco para matar os humanos, que sangram por dentro ao levarem uma flechada de Ani, cuja cura decorre de ação do pajé que canta, "bota" aray - chocalho usado pelo pajé - e recomenda passar urucum no corpo para ajudar a estancar a ferida e resguardar a vida da pessoa.

Dessa forma, partes do vegetal transformam-se em outra coisa, muitas vezes durável, a partir da mobilização de uma cadeia agentiva. A agência, nesse caso, não seria definida apenas pela intencionalidade de sujeitos, mas pela capacidade de provocar um encadeamento de transformações. As pessoas não seriam a única fonte de agência nas cadeias em que elementos heterogêneos são associados para a produção de coisas ${ }^{117}$.

Ingold (2012) interessado no processo de transformação das coisas mais do que no produto final e seu respectivo uso, elabora uma distinção entre objetos e coisas, sendo o objeto um fato consumado e as coisas, um "acontecer". O autor elabora uma crítica à noção de agência das coisas a partir do entendimento de que "[...] as coisas se movem e crescem porque elas estão vivas, não porque elas têm agência. E elas estão vivas precisamente porque não foram reduzidas ao estado de objeto" (2012:34). Por vida entende-se ser a capacidade geradora no campo das relações no qual as formas surgem e são mantidas. Os processos de vida das coisas estão centrados nos fluxos, nas matérias em movimento e em conectividade.

Para elaborar a distinção entre objeto e coisa, o autor parte das relações constitutivas de uma árvore, como sua casca, seus galhos, os musgos e ninhos de pássaros que nela se instalam, os insetos que vivem na casca que vivem na casca, o vento que gera movimento na árvore e conclui que a mesma não é um objeto, mas uma coisa, o que denomina como um "agregado de fios vitais" (Ingold 2012:29). Essa reflexão também se aplica a objetos e estruturas produzidas pelos humanos como uma casa, pois há um processo de vida inerente às coisas e isso é que gera a capacidade de transformar. Uma

117 Conforme Latour (2008) quando evidencia que a noção de agência não se define a partir da intencionalidade de um sujeito, mas na capacidade deste influenciar outro elemento na rede e assim gerar ação. 
casa tem diversos tipos de habitantes, entre homens, formigas e outros, e está exposta às condições do clima, ou seja, ao movimento das coisas que estão em seu entorno e por isso é experimentada como coisa e não como objeto. Para Ingold (2012), a produção de coisas não seria decorrência apenas da agência humana, mas do entrelaçamento do fluxo e da vida das coisas; e, nesta abordagem, não estaria relacionada à imposição de formas à matéria, mas como a atividade de um cozinheiro ou alquimista que redirecionam o fluxo das coisas e antecipam o que irá imergir.

No entanto, para a produção das coisas, não basta considerar os fluxos a elas inerentes, como bem demonstra Lévi-Strauss (2005:24-38), é necessário a observação exaustiva, a elaboração do inventário das relações, a ordenação e classificação das coisas e seres e a experimentação, além de intuição e imaginação, a exemplo do bricoleur. As coisas, portanto, expressam as qualidades sensíveis que as compõem, em especial as características ressaltadas a partir de sistemas de significados, e as relações que as constituem.

\section{Por ecologias ameríndias}

Ecologias ameríndias serão enfatizadas a partir de dinâmicas relacionais e interconexões entre as perspectivas humanas, não humanas, vegetais e animais e, portanto, em dimensões da socialidade. Descola (1987) advoga, nesse sentido, por uma "ciência das relações" quando busca ultrapassar o dualismo entre faculdades humanas e natureza física e o relativismo em torno da codificação do substrato físico pelas sociedades e argumenta que "[...] as entidades que constituem nosso universo só possuem um sentido e uma identidade através das relações que instituem enquanto tais. Embora as relações precedam os objetos que as conectam, elas atualizam-se no próprio processo pelo qual produzem seus termos" (1997:261).

Nesse sentido, o princípio do animismo consta como importante referência na conceitualização das relações entre os seres que povoam o cosmos por serem dotados, em alguma medida, de qualidades humanas e atributos sociais mediatizados por esquemas de interação onde prevalece a predação, como no modelo jívaro, e a reciprocidade, no modelo tukano (Descola 1996:89; Århem 2001:270). Algumas abordagens indicam que na cosmologia tukano a reciprocidade entre humanos e não 
humanos está calcada em um circuito fechado de intercâmbio energético - responsável pela manifestação de todas as formas de vida -, especialmente focado na caça, análogo à aliança simétrica entre grupos exogâmicos, em que animais caçados devem ser retribuídos por almas humanas formando um sistema eficiente de manejo dos recursos (Reichell-Dolmatoff 1976, 1977; Århem 2001:269; Descola 1996:89-90). Por outro lado, a ecologia simbólica jívaro pauta-se no princípio da predação e da instituição de relações entre diferentes seres do cosmos baseada em laços de consanguinidade, para as plantas domesticadas, e de afinidade, para animais encontrados nas florestas, calcados em mecanismos de vingança responsável por regular as relações entre esses seres (Descola 2005; 1996:90). Assim, predação e reciprocidade prevalecem como referências nessas dinâmicas relacionais.

"Apesar das diferenças que manifestam em sua organização interna, todas estas cosmologias têm como característica comum o fato de não fazerem distinções ontológicas absolutas entre os humanos, de um lado, e um grande número de espécies animais e vegetais, de outro. As entidades que povoam o mundo, em sua maior parte, são ligadas umas às outras em um vasto continuum animado por princípios unitários e governado por um idêntico regime de sociabilidade. Além disso, as características atribuídas a estas entidades dependem menos de uma definição prévia de sua essência do que de posições relativas que ocupam umas em relação às outras, em função das exigências de seu metabolismo e, sobretudo, de seu regime alimentar. A identidade dos humanos, vivos e mortos, das plantas, dos animais e dos espíritos é completamente relacional e, portanto, sujeita a mutações ou a metamorfoses de acordo com o ponto de vista adotado, posto que cada espécie deve perceber as outras espécies de acordo com seus critérios e necessidades próprias." (Descola 1997:249).

Ao focar este trabalho em relações que envolvem vegetais ${ }^{118}$, as quais não se configuram tão centrais quanto a relação entre caçador e caça baseada no modelo predador-presa, percebe-se que estão calcadas em combinações que abarcam multiplicidades diversas e que, em geral, envolvem mais do que dois termos. Além

\footnotetext{
${ }^{118}$ Vale aqui mais uma vez destacar que não se trata de uma categoria instituída e nominada pelos ameríndios e que, tampouco, pretende-se aqui conferir esse status ao termo empregado muito mais por falta de léxico apropriado. Assim, o uso do termo vegetal não reflete a complexidade semântica e nem categorias nativas quando empregado para discutir a diversidade de relações e sistemas de significados que envolvem o que, grosso modo, denominamos vegetais.
} 
disso, essas interações nem sempre são estabelecidas a partir de intencionalidades e subjetividades plenas e ativas. Elementos vegetais podem, então, como observado até aqui, ser classificados como plantados e não plantados, comestíveis e não comestíveis, que, em termos gerais, assumem distintas posições, que não são fixas, em redes de circulação entre seres e coisas como observado nos regimes alimentares, em relações de controle e criação, entre outras. Vegetais também participam de redes de transformações regidas por vetores de diferenciação, como na produção de coisas, conforme apresentando na seção anterior. Quando envolvidos em esquemas de predação, não necessariamente determinam a morte da presa. Frutos ou partes de plantas comidas por alguém, por exemplo, podem reverter em sua própria reprodução, como é o caso da castanha que é plantada pela cotia. O predador ativa a reprodução dos seres na cadeia trófica, mas também é responsável pela reprodução do próprio ser predado. Nesse sentido, uma característica atribuída a vegetais está relacionada ao fato de ser criado por alguém, ou até mesmo a sua própria autocriação, dinâmica que está ligada ao crescimento, reprodução e, no limite, a sua própria condição de vitalidade.

Nesse sentido, a demonstração feita por Marilyn Strathern no caso Hagen, nas Terras Altas da Nova Guiné, a partir da oposição entre $m b o$ - coisas cultivadas, atributos sociais - e romi - coisas selvagens, atributos não-sociais, solitário (2014a:47) pode nos dar uma pista sobre relações estabelecidas pelos ameríndios com elementos vegetais. Mbo está atrelado à criação, "refere-se às propriedades humanas de consciência e autoconsciência do domínio da interação humana, na qual o controle é internalizado" (op.cit.:50); romi está fora das relações que se baseiam em controle e da criação e, também, não diz respeito ao que é dado ou inato; o eixo mbo-romi expressa relações de diferença, oposições que não podem ser combinadas em uma única série ou tratadas como relações hierárquicas ou de domínio da cultura sobre a natureza; e, tampouco, relaciona-se a espaços geográficos como roça ou floresta. Contudo, nem todas as plantas enquadram-se na classificação mbo-romi como bem aplicada aos tubérculos, sendo que para algumas a classificação pode ser ambígua e para outras insignificantes (op.cit.:49). Strathern, ao abordar o eixo mbo-romi, diz que o contraste está entre o social e o não social e que foco "[...] está nas áreas de controle, influência e sustento" (2014a:58). A autora, dessa forma, demonstra como as categorias nativas não condizem com o contraste entre natureza e cultura, que seriam "[...] conceitos extremamente relativizados cujo significado último deve ser derivado de seu lugar no interior de uma 
metafísica específica" (op.cit:27). Por sua vez, focar nos pares de oposição marcados pelo social e o não social atrelados à classificação relativa à criação e autocriação atribuída às plantas, pode ajudar a compreender as relações que envolvem os vegetais e a elucidar o que denomino como gradiente de agência, situação que não exclui ambiguidades.

Nesse sentido, e partindo de pares de oposição acessíveis quando abordamos contextos ameríndios no que se refere à problemática do que, grosso modo, estamos denominando como florestas e (relações com) vegetais, como plantado e não plantado, comestíveis e não comestíveis, seres criados e autocriação, as posições não marcadas não abarcam relações de controle, mas não deixam de ser fontes de transformações em cadeias associativas, como a produção de artefatos. Assim, a condição de existência - "coisas que simplesmente existem", como entre os Araweté - instaura a possibilidade de estabelecer conexões que podem não envolver uma intencionalidade incisiva na constituição de vínculos, mas que, de qualquer maneira, está inserida em uma cadeia relacional, cuja base parte do "[...] 'existe, logo pensa', que instaura o pensamento imediatamente no elemento da alteridade e da relação, fazendo-o depender da realidade sensível do outro." (Viveiros de Castro 2012:168). Assim, vegetais aparecem como índices de relações diversas e operam multiplicidades que se definem nas redes de relações sociais efetivas e potenciais a partir da lógica das qualidades sensíveis e dos sistemas de significações. 


\section{Capítulo III - Dimensões da socialidade: produção de relações e percepções}

Como as pessoas se tornam aptas a circular nas florestas terrestres? Essa indagação conduziu a elaboração deste capítulo a partir do desenvolvimento de temas relacionados à fabricação de corpos, à produção de relações sociais e de percepções.

Dimensões da socialidade, processos de fabricação de corpos e modos de perceber e estar nos mundos estão imbricados nos modos de andar nas florestas, atividade que tanto exige a aquisição e o desenvolvimento de capacidades ${ }^{119}$ e qualidades quanto o estabelecimento de determinadas relações sociais, e que, portanto, vai muito além de faculdades físicas. ${ }^{120} \mathrm{O}$ que está em questão é a própria produção da vida e das relações sociais pelos e entre os ameríndios e entre esses e outros seres. Por outro lado, processos de fabricação de corpos e dinâmicas relacionais são determinantes nos modos ameríndios de perceber, conhecer e conceber florestas, as quais, por sua vez, são constituídas pelas relações que as engendram.

Vale, nesse sentido, qualificar a noção de socialidade adotada nesta tese. Não cabe aqui, no entanto, avançar no debate histórico acerca desse tema, especialmente no que se refere aos sistemas amazônicos (Viveiros de Castro 2002c, 2002d e 2000; Overing 1991; McCallum 1998, entre outros).

Ao criticar o entendimento teórico da noção de sociedade como entidade discreta, externa, abstrata e formada por seres humanos individuais em decorrência de sua pertinência no debate antropológico contemporâneo e nas narrativas etnográficas, Strathern (2014b:236) assume "o conceito de 'socialidade' como a matriz relacional que constitui a vida das pessoas e até mesmo 'sociedades' como um pluralismo de uso prático, representativo de populações com organizações distintas”. Com isso, a intenção é dar a devida importância às dinâmicas relacionais como inerentes à constituição das pessoas, em detrimento da oposição entre sociedade e indivíduo, e assim assumir a

\footnotetext{
${ }^{119}$ Não se trata aqui, como ressalta Ingold, de conceito de capacidade enquanto "enraizado nas metáforas de recipiente e conteúdo da psicologia humana como um conjunto de compartimentos modulares préconstituídos ou 'dispositivos de aquisição', aguardando para serem preenchidos com informação cultural na forma de representações mentais" (2010:17), mas enquanto habilidade, noção que será discutida no capítulo IV.

${ }^{120}$ É fundamental destacar que essas capacidades e dinâmicas relacionais não são desenvolvidas com a finalidade de proporcionar que os ameríndios circulem nas florestas, ou seja, não se trata de produção de competências para alcançar determinado resultado, mesmo porque esse não é um objetivo em si.
} 
máxima de que "[...] as relações sociais são intrínsecas, e não extrínsecas, à existência humana" (op.cit.:239). A partir desse pressuposto e daquilo que foi exposto nos capítulos anteriores, vale apontar que as relações sociais são também intrínsecas à constituição de florestas.

Seguindo esse percurso, é prudente dar atenção à questão colocada por Wagner (2010) com relação à existência de grupos sociais nas terras altas da Nova Guiné, ou melhor, ao modo como criam sua socialidade. "Nas sociedades tribais, é um tanto quanto sem sentido perguntar-se onde estão os grupos em si, pois eles nunca se materializam de fato" (Wagner 2010:250). Os contrastes criados têm menos o papel de definir e organizar grupos de forma consciente do que o de possibilitar que as pessoas estabeleçam continuamente distinções que gerem contrastes criativos nos próprios contextos relacionais, como apresenta o referido autor entre os Daribi, na Nova Guiné. O termo "socialidade" atua como forma "[...] de distinguir, de incluir e excluir; é, pois, meramente um dispositivo para estabelecer fronteiras. Um dispositivo desse tipo pode ser usado de forma muito flexível, estabelecendo ora esta distinção, ora aquela, sem nunca se vincular a um elemento particular ou a um "domínio" delimitado de definição" (op.cit.:247). A noção de socialidade desenvolvida a partir de etnografias melanésias aplica-se à discussão aqui proposta pela fluidez que imprime às dinâmicas relacionais sem deixar de marcar os contrastes que as constituem. Por sua vez, essas fronteiras são elementares para as composições e concepções de florestas pelos ameríndios.

Nesse sentido, foram privilegiados tanto noções sobre corporalidade quanto aspectos da socialidade ameríndia, no intuito de elucidar modos ameríndios de conhecer, circular e constituir florestas.

\section{Fazer relações, fazer gente}

Gente não nasce pronta, tem que ser feita. Esse é um tema recorrente na etnologia ameríndia (Lima 1996; Gallois 1988; Viveiros de Castro 1986; Figueiredo 2010; Araújo 2014, entre outros). Como ponto de partida, vale a reflexão de Lima (1996) sobre o que os Yudjá têm a dizer sobre a relação humano-animal: “[...] o que vocês consideram como características humanas (definindo-as tanto natural quanto metafisicamente) não pertence de direito ao ser humano. Temos de produzi-las em nós mesmos, no corpo. 
Cada um, animal ou humano, pode produzir as características que melhor lhe agrade" (Lima 1996:27). Disso surgem duas questões: i. quais são as características que constituem o humano; e ii: como essas características são desenvolvidas.

Se o corpo é o centro dessa construção da pessoa, cumpre apontar brevemente noções fundamentais enraizadas no debate antropológico americanista, segundo o qual o corpo não é determinado exclusivamente por processos fisiológicos, como notou Viveiros de Castro (2002) ao abordar o complexo xinguano de reclusão: “[...] todo esse complexo se radica na ideia de que o corpo é corpo humano a partir de uma fabricação cultural" (2002:75). O campo social é, portanto, fundamental na fabricação de corpos humanos, processo que acompanhará permanente e intencionalmente toda a trajetória da pessoa, do nascimento à morte. No entanto, não se trata apenas de inscrições sobre uma matéria inerte, e tampouco de corpos passivos às intervenções operadas pelas "sociedades". “[...] a corporalidade não é vista como experiência infrassociológica, o corpo não é tido por simples suporte de identidades e papéis sociais, mas sim como instrumento, atividade, que articula significações sociais e cosmológicas: o corpo é uma matriz de símbolos e um objeto do pensamento" (Seeger et alii 1979:20).

Produzir corpos humanos, no qual essa "construção e desconstrução" é a própria expressão das sociedades (cf. Strathern apud Taylor 2012:213), “[...] implica exibir um tipo especial de aparência corporal, praticar certos tipos de comportamento comunicativo e social e possuir certos estados de consciência” (Taylor 2012:216). Esses corpos criados adquirem subjetividade "[...] na noção que alguém tem da percepção que outros têm de seu próprio Eu" (Taylor 2012:217). A noção yudjá de "corpo" segue caminho similar quando condiciona a existência de corpos à dinâmica relacional, conforme observação de Lima: “[...] corpo e alma não são substâncias, mas relações ou posições, ou ainda perspectivas" (Lima 2002:11), e, portanto, permanentemente reafirmam sua condição.

Como se diferenciam tipos de gente se o processo de fabricação de corpos humanos não é prerrogativa dos seres humanos (Lima 1996; Viveiros de Castro 1996)? Nesse processo, o corpo aparece como elemento central, mas as distinções entre tipos de gente não estão calcadas em aspectos fisiológicos, como foi há tempos apontado por Viveiros de Castro, mas nos "[...] afetos, afecções ou capacidades que singularizam cada espécie 
de corpo" (1996:128), o que indica formas distintivas de se relacionar. Entre as características constituintes do humano está, portanto, “[...] o instinto social (no sentido de inclinação para a comunicação com outrem)" (Lima 1996:27), que na cosmologia yudjá se baseia “[...] em intervenções que neutralizam um afeto animal (agressividade e medo), freiam a volição e capturam capacidades e forças animais (como a audição excepcional do japim, a dentição do macaco, a resistência do tatu) ou vegetais (o som produzido pela taquara)" (op. cit.:28).

Como, então, fazer gente forte, bela e sociável que fosse inclusive apta a andar nas florestas? "Não se trata, ou não somente, de um corpo de substância, mas também de um formado pelos conhecimentos que orientam suas ações nos mundos. Em aweti, a raiz de "saber" (-kwawap) é a mesma do termo que designa consciência ou qualidade de quem age moralmente, ka'akwawapu. Este sentido, por sua vez, é um dos principais indicativos de humanidade [...]. Em suma, a condição de humanidade não será determinada apenas pelo compartilhamento de substâncias, mas também pelo compartilhamento de saberes e coisas" (Figueiredo 2010:95-96).

Para fazer gente, portanto, é necessário o acúmulo de relações, substâncias e saberes, em grande medida pela incorporação de capacidades e qualidades de outros, humanos e não humanos. A pessoa é constituída (e, concomitantemente, também constitui) em encadeamentos de relações, conforme mostrou Wagner (2011) ao discutir as aspirações do "big man" na Melanésia: "[...] uma pessoa fractal nunca é uma unidade em relação a um agregado, ou um agregado em relação a uma unidade, mas sempre uma entidade cujas relações estão integralmente implicadas" (2011:4). Nesse sentido, e incorporando as discussões sobre a noção indígena de pontos de vista a partir de etnografias amazônicas (Lima 1996; Viveiros de Castro 1996), é importante reforçar que em cada conexão, que é contextual, se assume uma posição relacional.

Entre os Araweté, ao nascer “[...] a criança é banhada em água morna; seu pai lhe fura as orelhas, raspa o cabelo que ultrapassa a linha das têmporas, e ela é então 'modelada' (mo-kati, consertada) por alguém experiente: achata-se seu nariz, afastam-se as orelhas para fora, massageia-se o peito, afastam-se as sobrancelhas, ajusta-se o maxilar inferior [...]" (Viveiros de Castro 1986:442). Restrições alimentares, sexuais, bem como quanto à execução de atividades, como não caçar ao menos até a queda do umbigo, são 
impostas aos pais, com vistas a evitar 'a 'queima' da criança, que resulta em sua morte [...] por febre, dessecamento e emagrecimento" (op. cit.:445). A condição humana é, pois, construída paulatinamente, mas também pode ser perdida a depender do comportamento e das atitudes subjacentes a uma relação. "A noção de 'ter consciência' - tradução mais geral do verbo kaaki - é central, embora vaga, para definir o grau de 'humanidade' dos infantes" (op. cit.:449), que, nesse caso, está atrelado à capacidade de comunicação, como o riso e a fala. Já entre os Aweti, o bebê não é gente porque existe como extensão dos pais. "Sua existência incerta também está ligada ao fato de ainda não possuir consciência das coisas a sua volta ( $\left.k a^{\prime} a k w a w a p u\right)$, nem de si (tekwawapu), nem dos outros (kajkwawapu, 'reconhecimento de nós')"'121 (Figueiredo 2010:187). Cabe aos pais os devidos cuidados, consigo e com o bebê, pois a conduta dos pais afeta o bebê, tanto durante a gravidez quanto no período pós-parto. "A conquista gradual de sua independência física representa menos que atingiu um estado de invulnerabilidade que a alteração das relações às quais é vulnerável. Ao possuir objetos, caminhar, ser objeto de práticas de fabricação corporal, alimentar-se de outras coisas que não apenas o leite materno, a pessoa expõe-se a outras relações necessárias e produtivas para sua formação, porém potencialmente daninhas" (op. cit.:192). Os cuidados envolvidos na criação de um bebê são tanto para evitar os perigos que envolvem os recém-nascidos, como a agressão xamanística (Gallois 1988:132), como para torná-lo humano à semelhança de seus parentes.

A criança "[...] precisa ser feita parente de seus parentes, visto que, nos mundos indígenas, as identificações substanciais são consequência de relações sociais e não o contrário: as relações de parentesco não exprimem 'culturalmente' uma conexão corporal 'naturalmente' dada; os corpos são criados pelas relações, não as relações pelos corpos" (Viveiros de Castro 2000:30). Os Panará, por exemplo, para se tornarem gente, têm de construir uma vida ativamente social, ou seja, devem estar disponíveis para interagir, manifestar disposição e ser belos, condição que denominam suakiin e que se contrapõe ao estado suangka, que caracteriza pessoas preguiçosas e antissociáveis (Ewart 2005:14, 16). Todo o esforço direciona-se, pois, para produzir pessoas suakiin.

\footnotetext{
${ }^{121}$ Em nota, a autora esclarece que " $k a$ 'akwawapu, termo que possui a mesma raiz de 'saber', kwawap, é usado em contextos variados para designar percepção apurada das coisas, capacidade de distinção entre o que é perigoso e o que não é, capacidade de distinção de um comportamento adequado aos variados tipos de relação" (Figueiredo 2010:187). Tal observação é muito relevante para a discussão do tópico seguinte, relacionado ao que denomino "saber perceber".
} 
Cultivar relações sociais, portanto, é uma característica da ordem do "humano". Uma aproximação pode ser feita com o povo Hagen, na Melanésia, para quem os atributos da vida social e a promoção das relações sociais são considerados características eminentemente humanas e são indicados “[...] por meio de expressões de criação [nurture]" (Strathern 2014:48) aplicadas a porcos, plantas e espíritos. "Parece que as ideias hagens aproximam-se muito das ideias daribi de que a socialidade é inata. Embora os indivíduos não tenham completa consciência de sua humanidade ao nascer, a criança desenvolve nela uma maturidade social em vez de ser treinada para tanto [...]. $\mathrm{Na}$ medida em que seu corpo ingere comida, ela responde à alimentação, adquire identidade, relações com os outros e, por fim, autoconsciência. A criança toma consciência da humanidade menos por meio da aquisição de habilidades, ou mesmo da capacidade de seguir regras, do que por meio da apreciação daquilo que as relações com os outros envolvem. Assim, não se acredita que o desenvolvimento da criança hagen recrie a domesticação original dos homens. Elas são menos 'socializadas' do que 'nutridas' [nurtured]" (op. cit.:51-52). A maturidade plena atesta-se pela incorporação e a conscientização das relações sociais, e essas são as características que marcam a condição humana.

Chegamos ao ponto central de que não se trata nem de indivíduo, nem de sociedade; nem parte, nem todo; nem coerção, nem comunhão. Ao longo da vida, o cotidiano, a convivialidade - mas não como uma "comunidade de similares" ou como "modos compartilhados de fazer as coisas" que engendram "princípios de homogeneidade comunitária" (Overing 1999:87), e sem negar as bases que fornecem as condições materiais de existência, ou seja, partindo delas -, a incorporação de relações, ou melhor, de modos de se relacionar, criam pessoas. Dessa forma, os modos como são constituídas as pessoas determinam, em grande medida, as concepções sobre florestas. À medida que eu me reconheço a partir do outro, me constituo pela similaridade e diferença em relação ao outro, pelo outro e com o outro.

\section{Saber perceber}

Para estabelecer conexões e para evitar perigos e conflitos, antes de qualquer coisa, é preciso saber perceber as relações e coisas ao redor. Se, ao andar pelas florestas, não se identificarem as possibilidades e os perigos a que se está suscetível, tampouco se terá a 
chance de obter sucesso na caçada, na coleta, ou de se proteger de eventual agressão, por exemplo. Se não se souber perceber onde estão os não humanos e seres que habitam as florestas (e quais são suas intenções), quais árvores ou animais possuem donos, as pegadas de onça, queixadas, entre outros, rastro e presença de cobras, caminhos de caça, épocas e locais adequados para a retirada de méis, locais apropriados para abrir cacimba, ficar-se-á exposto a perigos, à agressividade dos outros, a se perder nas florestas, a não encontrar a caça, enfim, a uma série de infortúnios. Por isso, é preciso desenvolver a capacidade de perceber e identificar esses contextos e relações para evitar situações indesejadas e de vulnerabilidade e, assim, ter a chance de ser bemsucedido nas empreitadas.

Perceber engaja experiências sensoriais, que, como demonstrado por Ingold, não são apenas resultados de configurações neuroanatômicas (2008:16), e tampouco de modelos sensoriais determinados pelas condições sociais (op.cit.:43). ${ }^{122}$ Para Ingold, que defende a premissa de que qualquer conhecimento se fundamenta em experiências sensoriais, a atenção deve estar no entrelaçamento das experiências vividas em seu engajamento prático no mundo e no modo como afetam a percepção das pessoas, e não em um entendimento de que as percepções seriam condicionadas por "modelos culturais", como abordado por alguns autores adeptos da antropologia dos sentidos (op.cit.:46).

Ingold observa o que denomina "engajamento participativo com o ambiente" entre os Koyukon, povo que vive da caça e da pesca nas florestas do Alasca, onde há a “incorporação da visão ao processo de percepção auditiva". "As árvores principais da floresta, nomeadamente pícea e bétula, assim como tantos de seus animais nativos, são investidas de espíritos que, como pessoas, podem ouvir tanto quanto ver. É por isso que, para os Koyukon, é sempre importante ser cuidadoso com o que se diz, para não causar nenhuma ofensa. Eles veem porque você vê; eles ouvem porque você ouve. Mas, indiferentemente, seja do lado das pessoas ou dos espíritos, é o elemento da atenção auditiva que converte visão em vigilância" (Ingold 2008:37). Com isso Ingold reforça sua posição de que as percepções sensoriais são intercambiáveis, não são universais, e

\footnotetext{
${ }^{122}$ Crítica contundente feita por Tim Ingold à antropologia dos sentidos, que, segundo o autor, "[...] parece determinada a deixar a experiência vivida e sensória para trás na busca do que ela representa, a saber, as 'ideias' e 'crenças' incorpóreas de uma cultura" (2008:45). Sua crítica à antropologia dos sentidos decorre do entendimento de que ela sucumbiu ao relativismo cultural ao instituir modelos sensórios atrelados a "modelagens culturais" (cf. Classen 1990).
} 
de que tampouco há primazia entre os sentidos (op.cit.:41), ao contrário, atrelam-se a experiências, e portanto ao envolvimento sensório com "o ambiente".

Mostramos, nos capítulos anteriores, que não se trata de "ambientes" nem de "mundos", mas principalmente de nexos relacionais entre seres e coisas, de corpos/pessoas constituídos a partir de conexões entre seres e de um "conjunto de afecções" (Viveiros de Castro 1996:128). Por isso, percepções são geradas a partir de encontros entre diferentes tendo como referência as relações aí implicadas, aspecto esse determinante nas experiências perceptivas e nos modos de constituir florestas.

Pautada em exemplos wajãpi de sensações apreendidas por diferentes seres do cosmos os homens sentem o gosto doce do mel, que, para a mamangava (espécie de abelha), tem o sabor de uma bebida fermentada, portanto azeda; cheiros agradáveis aos Wajãpi são fétidos para moju etc. - Oliveira afirma que "[...] diferenças perceptivas são devidas a distinções entre referentes. Entretanto, se pensarmos que os referentes não existem por si mesmos, mas sempre em relação a um sujeito, a percepção pode ser entendida como a própria relação, na qual mundo e sujeito interagem constituindo-se mutuamente" (2012:151). Para os Araweté, que entendem que a morte indica não o fim da vida, mas a fragmentação da pessoa (Viveiros de Castro 1986:494), entre as operações executadas no Mai para a transformação da parte da pessoa que subiu ao céu, no caso o princípio vital ativo (i), estão os aromas dos perfumes, os quais, por sua vez, têm o efeito de esquecimento das lembranças vividas nesta terra: “[...] os perfumes celestes, em sua função amnésica, se opõem claramente ao 'fedor da morte', o cheiro da carne podre, sítio das memórias do passado" (Viveiros de Castro 1986:524). O esquecimento acionado pela inalação de perfumes é fundamental no processo de transformação da pessoa no Mai, de o fazer tornar-se outro aos olhos dos viventes. Os cheiros, nesse caso, também acionam e posicionam relações.

Vale ainda marcar que, além do campo relacional, modos de ordenar as coisas são intrínsecos aos modos de perceber. "[...] as operações da sensibilidade já têm um aspecto intelectual, e os dados externos de ordem geológica, botânica, zoológica etc. nunca são intuitivamente apreendidos em si mesmos, mas na forma de um texto, elaborado pela ação conjunta dos órgãos dos sentidos e do entendimento" (Lévi-Strauss 2011:654). 
Não basta recorrer à visão, ao olfato, tato, enfim, aos sentidos do corpo; perceber algo ou alguém requer capacidade, a ser desenvolvida no dia a dia pelo processo de “fabricação de corpos" e de constituição de relações. Além disso, os sentidos, que são também apreendidos e constituídos nas relações, são fundamentais aos modos de perceber e conhecer. Entre os Piaroa, por exemplo, "a faculdade de inalar faz do nariz um instrumento poderoso nas artes xamânicas [...] Alucinógenos são fecundos - o xamã fica intencionalmente impregnado. Igualmente, pessoas comuns sentem o aroma da comida e são prazerosamente impregnadas. O órgão do nariz é uma passagem valiosa para adquirir conhecimento" (Overing 2006:47). Em ritual de caça Piaroa, jovens são expostos a formigas e vespas, cujo veneno é direcionado às partes do corpo que devem ser dotadas de resistência e força, pois "ensinar crianças a ouvir bem, ver bem e absorver bem é prepará-las para usar suas faculdades sensoriais no ambiente da floresta" (Overing 2006:45). Por outro lado, “[...] para os Caxinauá, o aprendizado não se dá na mera repetição daquilo que se ouve: mesmo os estímulos auditivos, sejam palavras, notas de música ou gritos de um animal, não são apenas som, mas igualmente - e em sentido aproximado ao de alimento - algo que penetra os corpos e as pessoas e pode alterá-los. Aprende-se não no ato mecânico de ouvir e olhar ou através de operações que se poderiam denominar puramente mentais, mas porque o corpo caxinauá, permeável à ação daquilo que se ouve e enxerga - ingere, sente, toca etc. -, se transforma." (Yano 2009: 103/104). Para os Araweté, ouvir (-enu) significa também entender. Quando me perguntavam algo em Araweté e eu entendia, assim eu lhes respondia: $A \boldsymbol{n} \boldsymbol{u} k u$ he (eu ouvi; eu entendi). A faculdade de ouvir está relacionada à capacidade de entender e ser capaz de conhecer, aprender, como observado entre os Suyá - "'[...] to hear is to understand and to follow Suya social codes [...]" (Classen 1990:729) - e os Desana "[...] say that sight recognizes categories while hearing leads to an understanding of them; to see is to perceive, to hear is to conceive" (op. cit.:729). Se, como apresentado entre os Caxinauá, as modalidades sensoriais transformam os corpos, elas também são determinantes nos modos de se relacionar e perceber os seres e as coisas ao redor.

A fala, por exemplo, pode engendrar tanto a capacidade de criar, como acontece entre os Guarani Mbya, cujo deus durante uma caminhada criava coisas ao enunciar seus nomes (Testa 2014:180), quanto a de destruir, em alusão ao que Viveiros de Castro (1986:511) denomina "audições perigosas" entre os Araweté: “[...] não se deve 
pronunciar a palavra "ovo" (hop̣̈nã) perto de carnes de quati e de peixes com dentes afiados [...], ou esses animais morderiam nossa barriga". Entre os Araweté não se deve pronunciar o nome de alguns animais, falar sobre suas qualidades ou de sua carne quando abatidos, como é o caso do tatu, por exemplo, pois alguns animais possuem há $\underline{\prime}^{\prime} e^{123}$ - espectro, princípio vital -, que pode gerar efeitos indesejados como dor de barriga ou algum tipo de enfermidade. Os Araweté dizem, por exemplo, que "não pode falar que vai pegar catapora", e isso se refere a qualquer doença, "não pode falar que a terra vai cair", porque, nesse sentido, a palavra é potente e desencadeia a ação.

Durante uma caça de jaboti com uma família nuclear araweté - acontecimento que será mais bem descrito adiante -, em um dado momento a atenção voltou-se ao ronco de queixada, ao seu cheiro fétido e, então, a esposa apontou e disse: "Olha, tajahu (queixada)!". A caça de jaboti é indicada pela expressão jate het $\int a$ (olhar - het $\int a$ - jaboti - jate -, "procurar jaboti") e, em grande medida, guia-se pelo aroma de partes das árvores, forma como os humanos esclarecem a busca dos jabotis por alimento, e pela procura visual dessas árvores pelos Araweté, como dito anteriormente.

Algumas etnografias ressaltam, entretanto, a preponderância de sentidos como tendência de certos povos no que se refere ao modo como as pessoas percebem os mundos - abordagem que aqui não é compartilhada -, como, por exemplo, a audição, entre os Yanesha (Santos-Granero 2006:102), ou entre os Inuit (Ingold 2008:7-10). No entanto, mesmo que em alguns momentos prevaleçam certos sentidos, no cotidiano e nas situações vividas não se tem como segregá-los ou reforçá-los como um "traço cultural", e são suas combinações que contribuem para a constituição das pessoas e os modos de conhecer seres e coisas. Assim, é relatado, entre os Nalu, que "nas situações em que os indivíduos têm de reconhecer uma planta para colher, fazem uso dos vários sentidos, não apenas da visão como também do tato, do cheiro e do paladar. É frequente cheirar as folhas ou mastigar a sua ponta, ou até cortar o seu caule para verificar o tipo de seiva, para confirmar se se trata da planta pretendida" (Frazão-Moreira 2001:149). Essa "integração dos sentidos em ação" é ressaltada por Ingold (2008) a partir de Merleau-Ponty e Gibson, autores que contribuem para sua fundamentação sobre as formas de percepção e compartilham o entendimento de que "[...] os sentidos existem

\footnotetext{
123 Para aprofundar sobre os componentes da pessoa e dos seres da perspectiva araweté, consultar
} Viveiros de Castro (1986:510-12). 
não como registros distintos, cujas impressões separadas são combinadas apenas em níveis mais altos do processo cognitivo, mas como aspectos do funcionamento do corpo todo em movimento, integrados na própria ação de seu envolvimento com o ambiente" (Ingold 2008:21).

Inúmeros exemplos etnográficos poderiam ser apresentados para compor o entendimento do que denomino "saber perceber" (que implica aprender a perceber) atrelado às qualidades sensíveis - o que é feito, de forma fragmentada, ao longo da tese - e relacionado à constituição de corpos e relações adequadas, bem como à incorporação de saberes e capacidades. Saber perceber, portanto, é prerrogativa de corpos feitos nas relações e engajados em nexos relacionais e relaciona-se a apreender a aprender. Não se trata, no entanto, de determinar se a percepção é causa ou efeito das relações, mas de indicar que é componente essencial de modos de se relacionar e conhecer.

\section{A potência dos nomes}

A onomástica é fundamental na constituição de pessoas e das relações por elas estabelecidas, por isso têm papel importante nas relações que constituem florestas e no modo como os humanos se comportam e se nomeiam quando circulam nas florestas. Gonçalves (1992:52-55), a partir de sistemas onomásticos guaiaki, sirionó e yanomami, observa que o nome se liga a qualidades a serem adquiridas: a criança recebe o nome de um animal caçado cujas qualidades são cobiçadas. Entre os Tupinambá, a produção da diferença se dá pela aquisição de nomes, por exemplo, de inimigos mortos; entre os Tapiraré, pelos nomes herdados da linhagem paterna. O nome é mais que uma designação, como observado por Nimuendajú entre os Apapocuva-Guarani: “[...] o nome é parte do possuidor, um "pedaço" idêntico a ele, inseparável da pessoa. O nome é a própria pessoa" (Gonçalves 1992:54). Possuir um nome pessoal significa existir.

Sistemas onomásticos são intrínsecos à constituição da pessoa e indicam mecanismos classificatórios e individualizantes. Esses sistemas partem de uma condição prévia fundada na relação de identificação entre nominador e nominado e, em especial, entre epônimo e nominado, como é evidenciado entre os Txicão (Ikpeng), em que há uma similaridade entre o epônimo, aquele de quem a criança receberá o nome, e o nominado, 
o que não ocorre entre o nominador e o nominado, dado que não há um laço durável entre ambos (Gonçalves 1992:58). Já entre os Apinajé, aquele que fez a pessoa não tem a prerrogativa de nominação; há uma relação de afeto com o genitor e uma identificação social entre nominador e nominado que ocorre na esfera pública (op. cit.:59).

Viveiros de Castro (1996), em uma abordagem comparativa dos sistemas onomásticos ameríndios, salienta os sistemas exonímicos e endonímicos, por um lado, e classificatórios e individualizantes, por outro, contrastando a onomástica tupi-guarani, que utiliza como fonte o extrassocial - natureza, inimigos e deuses - e é, em geral, individualizante, com a jê, calcada em sistemas onomásticos classificatórios que possuem acervos fixos de nomes, os quais designam relações sociais (Viveiros de Castro 1986:383-390).

Entre os Araweté, em 2012, logo em meu primeiro dia na aldeia Ta'akati, ao perguntar o nome de um bebê a seu pai, ele me respondeu: "Ana Clara". Para minha surpresa, o nome não só não era araweté, como, por coincidência, era o mesmo de minha primogênita. $\mathrm{O}$ pai da criança contou-me, então, que seu nome havia sido dado por uma enfermeira não indígena que residira um tempo na aldeia. Entre os Araweté, cada pessoa recebe um nome logo após o nascimento. Os nominadores são adultos ou pessoas mais velhas: em geral parentes próximos. Tatua ru foi o responsável por indicar o nome de Manahaju, filha caçula de Madai ru. Tatua ru mora na mesma área residencial de Madai ru, e, segundo me informaram, ele colaborou na concepção de Madai hi, esposa de Madai ru, pois a constituição da pessoa se inicia com a contribuição, por meio do sêmen, de diferentes homens. A atribuição do nome, por sua vez, remeteu a uma velha portadora do mesmo nome dado à criança, já falecida - por essa razão podiam usar seu nome, visto que entre os Araweté não se repetem nomes de pessoas vivas, ainda que seu repertório de nomes pessoais seja aberto. Uma criança pode ser nomeada “[...] 'conforme um morto do grupo' (pirowi'hã ne), 'conforme um inimigo' (awi ne) ou 'conforme uma divindade' (Maï de)" (Viveiros de Castro 1986:374). A atribuição dos nomes liga-se à relação afetiva ou a relações importantes para o nominador, no sentido de uma atualização da memória daquele que o portou, e não como repetição de papéis ou reposição da pessoa. Entre os Araweté, “[...] os nomes evocam os outros - deuses, inimigos, mortos -, são uma memória da exterioridade que cerca o mundo dos vivos" (op.cit.:383); marcam alteridades constitutivas das pessoas e 
estão sempre abertos a invenções. Retomando o caso de Ana Clara, a nominação ocorreu a partir de uma relação afetiva e sinaliza de forma evidente essa abertura para o outro no processo de nominar.

Porta-se o nome de infância até o nascimento e a nomeação do primeiro filho. ${ }^{124}$ "Quando nasce o primeiro filho, o casal 'joga fora' (heti) seus nomes de infância e muda (heriwã: virar, transformar) para os tecnônimos: 'Y-ro' e 'Y -ri', 'pai' e 'mãe' de Y (nome da criança) [...]. O primeiro filho é considerado um 'nominador' (herai re he) dos pais. Ele é nomeado muito mais rapidamente que os filhos subsequentes, a escolha de seu nome é objeto de maiores cuidados, e sempre se pensa no nome que os pais terão, ao nomear o filho. De certa forma, o que se está realmente nomeando são os pais, permitindo que deixem seus nomes de infância e atinjam o status de adulto: os tecnônimos são nomes mais 'próprios'; uma vez que se os obtêm, os nomes de infância viram automaticamente fonte de vergonha para seus ex-portadores $[\ldots]^{125}$ [op. cit.:368369; grifos do autor]. A mudança de nome advinda do nascimento do primeiro filho inaugura uma nova fase na qual a mulher, em especial, se volta para sua casa, apresenta um comportamento mais comedido, dedicando-se bastante ao filho, e passa a ter maior influência sobre o marido (op. cit.:461). Tal mudança ao longo da vida é relativamente frequente entre diversos grupos ameríndios, como Tapirapé, Marubo e Txicão (Gonçalves 1992:54, 57, 67).

Alguns interlocutores Araweté explicaram-me que uma criança pode ser nominada novamente caso adoeça de modo recorrente. Nessa circunstância, entendem que deveriam mudar o nome da criança para afastar as doenças. Entre os ApapocuvaGuarani, “[...] em casos de doença, quando todos os esforços para salvar o doente fracassam, o recurso utilizado é a troca de nome. O doente, ao receber o novo nome, torna-se um novo ser. A doença fica associada ao nome anterior” (Gonçalves 1992:54). Os nomes conferem, pois, capacidades ou infortúnios às pessoas.

\footnotetext{
${ }^{124}$ Vale a ressalva de que o nome que será reconhecido durante a maior parte de sua vida será aquele dado quando tiver seu primeiro filho. Por outro lado, Ana Clara não era a primeira filha, situação que indica que esse não é o nome de seus pais e que, daqui a alguns anos, provavelmente não estará mais vigente entre os Araweté.

125 "O que a tecnonímia consagra, a rigor, é a posição de pater, não a de genitor" (Viveiros de Castro 1986:372; grifos do autor).
} 
A nome(ação) revela, assim, sua potência agentiva, na qual um nome não é uma palavra aleatória, mas está associado a relações de significação e ao ato da fala, enfim, à própria enunciação, a qual está vinculada ao enunciador, ao ser ou objeto nomeado e ao próprio contexto de enunciação. O potencial de agência da palavra pode ser observado em cantos de cura entre os Wajãpi (Cabral de Oliveira 2012:191-192); nos benzimentos que agem sobre o corpo - quando a palavra não é pronunciada para fora, mas apenas internamente pelo benzedor -, como observado entre os Yuhupdeh no Rio Negro (Lolli $2010^{126}$ apud Oliveira 2010:190); no cuidado em não pronunciar o nome de infância de um adulto em sua presença, como entre os Araweté, o que "[...] produziria 'medovergonha' (ciye $)$ e 'raiva' (mo-irã ) no nomeado [...]" (Viveiros de Castro 1986:367); na evitação de pronunciar o nome de alguém, como sucede entre os Yanomami, pois nesse caso "[...] um vivo corre o risco de morrer, e um morto, de reaparecer (na forma de espectro)" (Gonçalves 1992:56). O potencial de agência ao nomear pessoas e coisas e proferir enunciados vincula-se às relações e associações engendradas na nomeação e nas intenções imbuídas na fala, por sua vez iminentemente relacionadas ao contexto de enunciação.

Para os Awá-Guajá os nomes são oriundos de animais, plantas situações e objetos, e “[...] cada portador mantém uma relação de contiguidade com esses seres, objetos e fenômenos. Os humanos são jará desses que consideram nimá, não como xerimbabos, mas, nesse caso, 'duplos metafóricos', potências associadas a tais agentes humanos" (Garcia 2010:231). Entre os Wajãpi, “[...] para proteger uma criança, deve-se dizer-lhe o nome humano, para evitar que ela seja considerada como uma criança sem dono, prestes a ser raptada pelos seres sobrenaturais. Para proteger uma pessoa adulta, evita-se pronunciar seu nome justamente porque, nessa idade, os indivíduos já acumularam uma série de relações - de conflito ou cooperação - com essas entidades. Identificar a pessoa pelo nome seria chamar a atenção sobre ela [...]" (Gallois 1988:180-81). Os nomes, portanto, além de contribuir para a produção de corpos e pessoas e carregar uma potência agentiva, referem-se a campos relacionais. A atribuição dos nomes entre os Daribi, segundo Wagner, coloca em jogo referências que marcam campos relacionais. Assim, “[...] qualquer reconhecimento ou atribuição de um nome é sempre a fixação de

\footnotetext{
${ }^{126}$ Lolli, P.A. As redes de trocas rituais dos Yuhupdeh no igarapé Castanha, através dos benzimentos e das flautas Jurupari. Tese de doutorado. FFLCH/USP, São Paulo, 2010.
} 
um ponto de referência em meio a uma gama de relações potencialmente infinita, uma designação que é inerentemente relacional" (Wagner 2011:5).

Os nomes, portanto, criam dimensões de socialidade, revelam modos de articular as relações, contribuem com a produção de pessoas e também são imbuídos de potencial agentivo que pode ser acionado tanto pelo portador do nome quanto pelos outros. $\mathrm{O}$ uso adequado dos nomes contribui, portanto, para evitar situações de perigo e vulnerabilidade, e esse conhecimento é essencial para circular nas florestas.

\section{O sangue é líquido, cru e fétido}

Para os ameríndios, em geral, o sangue é líquido, cru e fétido, e a proximidade ou o distanciamento de seu fluxo assinalam modos de interação não verbais que, no limite, podem colocar a vida em perigo. A relação com o sangue requer comportamentos prescritos que impõem sistemas de resguardo e cuidados. O sangue opera no próprio sujeito e na interação com os outros.

$\mathrm{Na}$ Amazônia indígena, a perda de sangue no período menstrual e no pós-parto é considerada perigosa para aqueles que compartilham a existência pelo fato de a contaminação com essa substância causar transformações e provocar doenças, segundo Belaunde (2006:217-19). As mulheres, durante esses períodos, devem seguir comportamentos prescritos, evitar determinados alimentos, relações sexuais, ficar na beira do rio e caminhar na floresta. Entre os Araweté o termo wi pe $e^{127}$ (wi, "cru"; e pe, "caminho") significa sangue; se wi é usado para indicar algo que está cru, estado que remete a interdições, por analogia infere-se que o contato com o sangue deve seguir algumas restrições, como veremos adiante. Os Araweté não praticam rito de passagem durante a menarca ou mesmo no pós-parto, exceto alguns interditos alimentares e a proibição de sexo, a qual vale enquanto durar a menstruação. Na puberdade, as meninas passam a utilizar obrigatoriamente uma cinta interna debaixo da saia, que não deve ser retirada em público. É recomendável que antes da primeira menstruação (heyi, “descer o sangue", wi, sangue) a moça já tenha tido relações sexuais. "O sangue que flui é

${ }^{127}$ Wi possui um cognato entre os Wajãpi, que "[...] utilizam pelo menos dois termos para designar sangue: $w y$, que é um termo genérico, e ute, para designar especificamente o sangue menstrual" (Rosalen 2005:58). 
considerado 'esfriar' a menstruada, que está portanto 'quente' (haki) ${ }^{128}$ [...]. Ela deve evitar banho de rio - causaria inundações ou chuvas fortes -, e sexo, pois o contato sexual com uma menstruada pode fazer o homem sofrer de $h a$ 'iw $\underline{\tilde{a}}^{129}$. As mulheres menstruadas, além disso, 'cheiram mal' (ikacị), não podem mastigar o cauim. Mas podem cozinhar" (Viveiros de Castro 1986:460). As mulheres não podem preparar nenhum tipo de bebida quando estão menstruadas, sob o risco de causar dor de barriga naqueles que a ingerirem. Também não comem, na puberdade, “[...] nem coração de jaboti, veado e outras caças - peças que sangram muito, em geral -, pois senão sua menarca será abundante e dolorosa" (op. cit.:460). No período da couvade, devem seguir regras alimentares - comer apenas arroz, trairão, pacu, piranha e mutum; não devem comer nada muito quente, nem o marido, nem a esposa, para que a criança não fique magra -, evitar atividades físicas e sexuais; as mulheres não pode cozinhar, e os homens devem evitar as atividades de caça, pois se encontram em situação de vulnerabilidade. Percebe-se a partir dessas situações que o sangramento, cuja substância se apresenta em estado líquido e cru, aciona relações de contiguidade e contágio que não se circunscrevem ao grupo de substância, ${ }^{130}$ mas, ao contrário, produzem efeitos indesejados em todos aqueles que porventura entrem em contato com as bebidas preparadas pelas mulheres menstruadas, com partes de animais caçados sanguinolentas, com o próprio sangue, de forma direta ou indireta, nesses momentos liminares. Já entre os Karitiana continua valendo o princípio do contágio, mas, em sentido inverso, o contato com "outros sangues" pode trazer benefícios, como "[...] esfregar o sangue de uma anta abatida no corpo - porque o sangue da anta "é forte" (Vander Velden 2007:279) e faz o sangue humano ficar forte e grosso, características que indicam boa saúde.

\footnotetext{
${ }^{128}$ Os Araweté dizem que quando nasce o bebê os pais não devem comer comidas quentes, senão a criança ficará magra. Não é o intuito aqui abordar a influência dos estados quente e frio na fabricação do corpo, mas temos pistas de sua relevância.

129 "[...] ha'iwã a aquilo que destrói a saúde corporal e/ou rompe o delicado vínculo corpo e alma" (Viveiros de Castro 1986:466).

${ }^{130}$ Em nota, Viveiros de Castro (1986:438-39) esclarece que usa "[...] a noção de 'grupo de substância' em sentido lato, uma vez que não sei que 'substância' é essa que define o conjunto de pessoas que os Araweté consideram como afetos à regra de abstinência por doenças. Visto não ser o sêmen (cf. matrilateralidade), tampouco é o sangue. Seria mais bem uma 'unidade mística', substância metafórica ou metonímica: é um grupo sociológico, vale dizer, não fisiológico (etno-)". O termo "grupo de substância" por mim utilizado segue a mesma observação de Viveiros de Castro, dado que não me aprofundei no entendimento da temática do contágio e dos afetos.
} 
Uma jovem tuyuka contou que, “[...] quando está menstruada, corre grande perigo passando por certos lugares sagrados ou tomando banho de rio. Se ela contar ao marido que está menstruada, correrá riscos ainda maiores. Se não contar (não mencionar, não falar, não pronunciar sobre seu estado), então esses seres (agressivos) não são sobreavisados: assim não sabem, não a veem e não a agridem. Mencionar a menstruação ao marido já serviria de alerta aos agressores. Daí por que muitas moças evitam falar, segundo ela, que estão menstruadas. Algumas não evitam aproximação maior com os homens e vulnerabilizam os conhecedores e saberes que portam" (Cabalzar 2010:163). Entre os Wajãpi, o sangue é um veículo que carrega o princípio vital (ã) da pessoa, e por isso o contato com ele pode trazer infortúnios, especialmente o contato com o sangue de pessoas que não fazem parte de seu grupo de substância, com o sangue menstrual ou com o sangue derramado no período de couvade. Além disso, seu forte odor atrai os donos dos animais caçados, que podem agredir tanto o caçador quanto aqueles que preparam a caça, principalmente no caso de a mulher estar menstruada. Aproximar-se do sangue significa poluir-se com seu odor. Os Wajãpi recomendam, assim, evitar o contato com o sangue, ter cuidados na atividade de caça, obedecer às prescrições e proibições nos resguardos, especialmente no período de couvade, para prevenir agressões e outros efeitos indesejados, como preguiça, fracasso nas caçadas ou o desejo de seres não humanos (Rosalen 2001:58-63). A presença do sangue regula a boa distância entre as pessoas e os seres, sendo sua proximidade excessiva capaz de gerar transformações indesejadas e irreparáveis.

"Embora o sangramento seja em princípio definido como um atributo feminino, para ambos os gêneros verter sangue leva a uma mudança de canihuë, 'pele/corpo'. Esse sangramento é necessário para a fertilidade e a renovação, mas ele também torna homens e mulheres vulneráveis ao ataque dos espíritos sedentos de sangue. Observar um período de resguardo, com dieta e reclusão, é a melhor forma de regular a dinâmica transformacional movimentada pelo sangramento e por seu cheiro" (Belaunde 2006:210). O sangue e seu cheiro atraem agressores, que seduzem ou raptam os humanos, transformando-os por meio da doença ou levando-os até mesmo à morte (op. cit.:229). A transformação associada ao sangramento é observada entre os Wajãpi, para quem “[...] a relação irmã/irmão se constrói em torno da ideia de transbordamento de sangue: o advento do sangue menstrual da menina indica que o rapaz pode, a partir desse momento, derramar o sangue dos animais" (Gallois 1988:141), momento que 
indica que está liberado para a caça. Escarificações também eram feitas, outrora, “[...] nos braços dos caçadores e na barriga das mulheres. Para estas, a finalidade era a mesma que a da aplicação de formigas: "não ter preguiça"” (op. cit.:141). O sangramento também é administrado com vistas a assegurar a boa saúde dos homens yawalapiti. Se a perda de sêmen enfraquece, assim também faz a retenção de sangue, razão pela qual os homens se submetem à escarificação e à ingestão de eméticos para expulsar o sangue acumulado na barriga (Viveiros de Castro 1987:46). O controle do sangramento por meio de resguardo, dietas, distanciamentos e escarificações é fundamental tanto pela vulnerabilidade e o perigo de ocorrerem transformações descontroladas quanto pelo próprio processo de fabricação dos corpos. O sangue, para os ameríndios, igualmente se associa à vitalidade e deve circular de forma equilibrada nos corpos a fim de garantir boa saúde, bem-estar (Vander Velden 2004:120) e capacidade de estabelecer relações plenas (Belaunde 2001 131 apud Vander Velden 2007:292).

É corrente nas etnografias amazônicas, de acordo com Belaunde (2010), o entendimento de que o fluxo sanguíneo aumenta à medida que a pessoa cresce e adquire capacidades, sendo as experiências incorporadas ao sangue. "Todas essas experiências vividas são incorporadas ao sangue, diferenciando homens e mulheres, bem como diferenciando uma pessoa de outra de forma única" (Belaunde 2010:215). Assim, o sangue também é reconhecido por ser substância portadora de potencialidades e conhecimentos. "[...] uma variedade de etnografias mostra que o sangue é concebido como uma relação porque ele circula pelo corpo, pondo todas as suas partes em comunicação e enchendo-as de pensamento e força para a ação intencional” (Belaunde 2006:210). Entre os Piaroa, é pela corrente sanguínea que os pensamentos circulam pelo corpo, “[...] provendo cada membro e órgão com inteligência para agir" (Overing 2006:20), e por isso “[...] o sangue sempre é portador de conhecimento" (op. cit.:38). O sangue e seu fortalecimento são responsáveis pela fabricação da pessoa ${ }^{132}$ e pela circulação de conhecimentos tanto

\footnotetext{
${ }^{131}$ BELAUNDE, L.E. Viviendo bien: género y fertilidad entre los Airo-Pai de la Amazonía Peruana. CAAP/BCRP, 2001.

${ }^{132}$ Viveiros de Castro (1986:438), ao abordar o tema da concepção entre os Araweté, mostra que os componentes da pessoa estão potencialmente no sêmen - que congrega carne, sangue, ossos e alma/princípio vital - e que o sangue não contribui com a formação da criança, entendimento que difere do dos Wajãpi, que afirmam que "os pais passam o princípio vital para o filho através do esperma, enquanto a mãe o faz através do sangue que antes era destinado à menstruação" (Rosalen 2005:101-02). No entanto, em casos de doença ou de incesto, restrições e interditos são recomendados aos parentes tanto patrilineares quanto matrilineares.
} 
entre as diversas partes do corpo como nas relações entre os diversos seres onde o sangue se manifesta como operador, como observado entre os Pano (Yano 2010:132$33)$.

O sangue, por sua consistência líquida, por ser uma substância crua, pelo seu forte odor ou pelo fato de a mulher pronunciar que está menstruada, produz estados de vulnerabilidade que requerem abstinências e cuidados para proteger a si e aos outros que com ele entram em contato, de forma direta ou pelos grupos de substância, cuja delimitação não se restringe a aspectos fisiológicos. Por ser encontrado em estado amorfo e por sua consistência, gera repugnância. Para os Jívaro, por exemplo, se as mulheres comerem alimentos que escorrem ou esparramam como o sangue, as plantas que cultivam na roça tendem a estragar (Lévi-Strauss 1991:29). Essa capacidade do sangue de produzir efeitos e gerar consequências indesejadas liga-se, de certa forma, ao fato de ser "elemento que aciona a esfera da natureza", como aponta Rosalen (2005:58), ou, para além dessa formulação da natureza per se, por sua associação com o estado cru, como indicado no termo araweté $w i,{ }^{133}$ e pela aproximação entre mel e sangue menstrual estabelecida por Lévi-Strauss especialmente a partir de um mito warrau (M273) que narra a história de uma criança roubada. A partir dessa narrativa, LéviStrauss (2004) estabelece correlações entre mel e sangue menstrual nas quais conecta o plano alimentar ao sexual, mais especificamente o alimento ao excremento, no intuito de mostrar a desordem das coisas e o perigo de transitar da cultura para a natureza, ao ressaltar a toxicidade de méis sul-americanos, que aproxima aquilo que é delicioso do venenoso, os interditos relativos às mulheres menstruadas, que podem remeter tanto a sedução quanto a sujeira, ou quando um homem é comido cru por um jaguar ao invés de o animal ser comido cozido pelo homem (2004:237-38).

Para complementar essa reflexão, uma interlocutora araweté relatou-me que ingerem água com cinzas para anular o efeito de dor vigente no período menstrual. Nota-se aqui a oposição entre mel e cinzas, entre o que se situa aquém e além da cozinha, e com isso traça-se o paralelo entre sangue menstrual e mel e o perigo de perder ou transformar o modo como as relações operam, colocando em risco a própria vida. Por outro lado, o

\footnotetext{
${ }^{133}$ Viveiros de Castro (1986:470-71) afirma que não observou se os Araweté atribuem importância ao sangue enquanto elemento simbólico. Também ressalta que os Araweté não tomam maiores cuidados com o sangue e que, por vezes, comem carne malpassada, não sendo tão rigorosos quanto ao cru, cuja ingestão não deixa de provocar efeitos indesejados, como fortes dores abdominais.
} 
sangue carrega vitalidades, experiências e conhecimentos, e uma boa saúde está relacionada a sua plena e equilibrada circulação pelo corpo. De uma forma ou de outra, o sangue constitui uma substância impregnada de potência, portanto capaz de acionar reações, relações e transformações. Assim, coordenar o contato com seu fluxo é elementar para ter boa saúde e boas relações. Nesse sentido, a presença e o contato com o sangue são determinantes nos modos ameríndios de se relacionar e, consequentemente, andar com segurança nas florestas.

\section{Efeitos dos vegetais nos corpos}

Folhas, cascas, entrecascas, seiva, sementes, frutos, caules, flores e rizomas são usados pelos ameríndios por infusão, maceração, ingestão, decocção, mastigação, aspiração, fricção, pintura, audição, olfato, visão, paladar, entre outros procedimentos para curar doenças e dores, atrair, seduzir e repelir pessoas, espíritos e animais, para formar bons caçadores, no pós-parto, para aprender a falar e andar, para nutrir, para proteger, para enfeitar e perfumar, para constituir seres fortes, provocar a surdez, enfim, para obter diversos efeitos nos corpos. ${ }^{134}$

A produção de corpos ocorre, como discutido no início deste capítulo, por meio de intervenções, pela adoção de determinadas condutas e pelo desenvolvimento de qualidades que, em alguma medida, são incorporadas dos outros, sendo os vegetais bastante acionados nesses processos. Os corpos, como observado entre os Yawalapiti, precisam ser submetidos a processos intencionais de fabricação concebidos " [...] como um conjunto sistemático de intervenções sobre as substâncias que comunicam o corpo e o mundo: fluidos corporais, alimentos, eméticos, tabaco, óleos e tinturas vegetais" (Viveiros de Castro 1987:40).

Nesse contexto, vegetais atuam como substâncias ou índices que carregam capacidades e qualidades capazes de transformar os corpos e produzir relações sociais, cujos efeitos não devem ser atribuídos apenas a eles. Como bem ressalta Yano (2010:106) a partir de

\footnotetext{
${ }^{134}$ As plantas usadas na alimentação são de grande importância na formação de corpos, mas esse é um tema que não está em foco neste item. No tópico seguinte, trataremos de aspectos da alimentação no que se refere à fabricação de corpos e à constituição de relações sociais.
} 
observação de Erikson ${ }^{135}$ sobre a aplicação do kampu - secreção extraída de uma espécie de rã e usada como estimulante cinegético - entre os Matis, a eficácia provém também do aplicador e do contexto de aplicação, observação válida para o uso de vegetais quando envolvidos na produção de corpos.

Quais são, então, os atributos e configurações que contribuem com a eficácia dos vegetais no processo de fabricação de corpos ameríndios? O que pode ser qualificado como sendo "substâncias" - que não se configuram apenas como componentes materiais, mas também concernentes aos idiomas sensíveis, sociais e simbólicos, como veremos adiante - que os vegetais carregam e que são determinantes nas intervenções e efeitos sobre os corpos?

Primeiramente vale a ponderação de que não se podem destacar os vegetais dos contextos de interação e das experiências que os envolvem. Se aqui tomamos a liberdade de usar exemplos etnográficos descolados de seus contextos mais abrangentes, é apenas no sentido de ampliar o levantamento de situações que permitam trabalhar o entendimento das lógicas e dinâmicas ameríndias que regem os "efeitos dos vegetais nos corpos", sem, no entanto, desvincular das relações implicadas e dos sentidos e significados a eles subjacentes. Não se trata, portanto, de desvendar princípios ativos dos vegetais para o tratamento de enfermidades - objeto este da fitoterapia, embora o uso de vegetais na farmacopeia ameríndia seja amplamente difundido -, mas sim de desenredar os envolvimentos de vegetais na produção de corpos, no caso humanos, a partir de perspectivas ameríndias. Nesse sentido, vale adotar as reflexões acerca da consubstancialidade que envolve o debate sobre substâncias ${ }^{136}$ como produtos das relações, e não o contrário, e aplicá-las, guardadas as particularidades, à discussão sobre os "efeitos dos vegetais nos corpos". "A consubstancialidade, em outras palavras, é algo que se reconhece por seus efeitos; ela não poderia ser medida de antemão no laboratório, e não só porque faltem aos índios a ciência e os instrumentos, mas porque se trata de uma qualidade mutável que depende do modo como os sujeitos conduzem o relacionamento e que se revela por intermédio de efeitos visíveis nas pessoas envolvidas - em seus corpos. Isto é, ela é um produto desse relacionamento; não uma linguagem

\footnotetext{
${ }^{135}$ ERIKSON, P. '“Comme à toi jadis on l'a fait, fais-le moi à present...' Cycle de vie et ornamentation corporelle chez les Matis (Amazonas, Brésil)" L'Homme, 2003.

${ }^{136}$ Coelho de Souza (2004:38-47) faz uma breve síntese da noção de substância que ganhou destaque na etnologia a partir de reflexões sobre o parentesco entre grupos jê.
} 
(figurada) que permite a 'manipulação' de relações reais, mas um efeito real de uma 'manipulação' [...]”' (Coelho de Souza 2004:44). Ou seja, com isso se reforça, guardadas as especificidades e as ordens envolvidas (humanos e vegetais), mais uma vez a perspectiva defendida ao longo desta tese de que os "efeitos dos vegetais nos corpos" se associam, em grande medida, às dinâmicas relacionais que abarcam tanto vegetais e corpos/pessoas - como operadores de relações - quanto os contextos de aplicação de substâncias/componentes vegetais nos corpos, os quais compreendem, em grande medida, as posições experimentadas nessas situações.

Vegetais podem então acionar e potencializar comportamentos e capacidades nos corpos, tornando-os humanos e plenos, para neutralizar - mas também produzir malefícios decorrentes de relações consideradas inapropriadas ou perigosas, ou mesmo mudar a condição das relações e, portanto, as posições dos envolvidos, para a cura de doenças, para ornamentar, atrair e seduzir ou para estabelecer canais de comunicação entre os seres.

Os Araweté usam a folha de um arbusto encontrado próximo das casas para produzir a fala nos bebês. Esse efeito decorre do som emitido ao se partir a folha - ka'a ne'e ato (ne'e, "falar") - com os dedos próximo ao ouvido do bebê e, concomitantemente, do pronunciamento de algumas palavras em araweté. No caso, o som estimula o aprendizado da fala, que "[...] é um sinal importante e ansiosamente esperado de maturação" 137 (Viveiros de Castro 1986:449). Os Aweti usam plantas com nomes de filhotes de animais que andam rápido, como "“andador de filhote de corujinha', 'andador de filhote de mutum', 'andador de filhote de jaguar'” (Figueiredo 2010:213), com vistas a ajudar as crianças a caminhar - essa aplicação estaria relacionada ao uso de substâncias das quais que esses animais são donos (itat), ${ }^{138}$, portanto usuários e conhecedores -. Entre outros procedimentos, os aweti utilizam também um preparado com folhas de algodão ou com mato de rápido crescimento, que é lançado nas costas e joelhos do filho pequeno para este ficar leve e, assim, ter mais facilidade para andar (op. cit.:213-14). Nesses casos, vale também o entendimento de que a aplicação de vegetais

\footnotetext{
${ }^{137}$ Viveiros de Castro (1986:449) concebe esse procedimento como um ritual mágico a que ele foi, inclusive, submetido para facilitar seu aprendizado da língua araweté.

${ }^{138}$ As espécies que têm donos são perigosas e devem ser usadas com cuidado (Figueiredo 2010:214).
} 
remete a uma espécie de cadeia relacional por afinidade e similaridade entre qualidades sensíveis dos vegetais, características etológicas e capacidade a ser potencializada.

Para o bebê crescer forte e alegre e para prevenir estados prejudiciais, os Karitiana ministram "vacinas do mato" à base de folhas ${ }^{139}$ coletadas na mata (Araújo 2014:64, 86, 87). As "vacinas do mato", combinadas à dieta alimentar da mãe durante a couvade, ${ }^{140}$ produzem corpos belos, limpos - ao serem aplicadas vacinas de "duas árvores de grande porte, que na floresta se destacam das demais por seus troncos lisos, coloridos e brilhantes" (op. cit.:87) -, pessoas calmas e sociáveis, ajudam a criança a aprender a andar e protegem o bebê das ofensivas de "espíritos"141 (op. cit.:123). De volta aos Araweté, no dia do parto os pais devem “[...] tomar uma infusão amarga da casca da árvore iwirar $\underline{a}[. .$.$] a mesma que mulheres menstruadas e matadores tomam, e cujo$ sentido, assim, parece ser o de purgar o sangue que se acumula no corpo nesses estados. Mas a explicação Araweté é que se toma o iwirara 'para comer jaboti' (sem sufocar por inchaço da glote) - a primeira carne, normalmente, comida pelos pais" (Viveiros de Castro 1986:443). Conforme meus interlocutores, após tomar essa bebida amarga (ida mee) podem comer jaboti novo, farinha e queixada; já a mãe do bebê, ao ingerir essa bebida, evita ter dor na barriga após o parto. O período da couvade é um momento muito delicado, pois com o nascimento um novo ser deverá criar uma rede de relações que o ajudará a tornar-se humano. Vegetais são também usados no processo de transmissão de conhecimentos, como é mostrado entre os Caxinauá, cujo princípio está na incorporação de "forças externas" que pode ocorrer pela ingestão de certas bebidas, como a ayahuasca (McCallum 1996:56).

As qualidades dos vegetais podem, também, acionar dinâmicas relacionais. Os Wajãpi associam determinados vegetais e respectivos aromas à proteção pelo fato de dissimularem o corpo e assim afastarem os agressores atraídos por cheiros fétidos (Cabral de Oliveira 2012); os Guajá colocam partes aromáticas de vegetais em infusão na água, que posteriormente é borrifada no corpo das crianças para atuar como analgésico ou antitérmico. "Para os Guajá, borrifar sobre o corpo uma infusão odorífera

\footnotetext{
${ }^{139}$ Para os Karitiana, os vegetais são dotados de agência e subjetividade, aspectos que possibilitam o estabelecimento de relações sociais (Araújo 2014:70).

${ }^{140}$ A gordura presente em carnes de anta e porco, por exemplo, anula os efeitos das "vacinas do mato", deixando a pessoa vulnerável e sujeita a situações perigosas (Araújo 2014:89).

${ }^{141}$ Para saber mais sobre a noção de espírito entre os Karitiana, consultar Araújo (2014:123-30).
} 
proporciona uma barreira protetora contra a penetração do mau cheiro do aiyã no indivíduo. Tal intrusão resultaria na 'devoração' $(u$ 'u) da alma da pessoa pelo aiyã. Se o efeito desejado da infusão é perfumar o corpo com uma substância aromática, então é claro que o resultado desejado é efetivamente obtido" (Cormier 2005:135-36). Em outro sentido, os vegetais são usados para produzir capacidades constitutivas da socialidade, como "[...] ouvir/entender (ninka-), ver (uin-), ser calmo, falar, caçar etc." (McCallum 1998:131), como acontece entre os Caxinauá, que, assim como os ameríndios em geral, valorizam a generosidade como base de suas relações sociais.

Recorre-se aos vegetais no combate a doenças ${ }^{142}$ que acometem as pessoas e seus componentes vitais, mas certos vegetais podem também provocar a morte, como afirmam os Yudjá na narrativa sobre a morte de um xamã magnífico em decorrência de uma resina de jatobá que foi passada em uma flecha; a alma da resina (resina-ïsami) fixou-se no peito do xamã, vindo a ocasionar sua morte (Lima 2005:62-63). Para os Caxinauá, o perfume exalado pela sumaúma é considerado agente patogênico (Yano 2010:119). Os Araweté, para indicar alguns usos de partes dos vegetais, bebem água de um cipó para tratar problemas gastrointestinais; para curar dor de barriga, também recomendam mascar iwira'i pidé (casca de árvore), que é bem amarga; os pajés, em ação complementar ao tratamento xamânico para picada de cobra, usam a folha de um arbusto. Os Awá aplicam emplastro de casca de árvore para o corpo expelir o veneno de cobra no caso de picada; para tratar dores musculares, usam folhas amassadas que, misturadas à água e ao mel ou aquecidas no moquém, agem como antitérmico; para machucados ou queimaduras, usam a seiva de entrecasca de árvore; além da casca de uma árvore cujo cheiro combate febre e calafrios e da entrecasca de outra árvore cujo amargor trata dores gastrointestinais, entre outras aplicações (Garcia 2010:108-09). Entre os Ka'apor, o uso de plantas para o tratamento de doenças foi cuidadosamente descrito por Balée (1994a:108-15). Entre os Yora e os Matsiguenga, o odor é um dos principais agentes curativos (Sheppard 2000; $2004^{143}$ apud Cormier 2005:132). Para

\footnotetext{
${ }^{142}$ Para saber mais sobre noções de doença entre os ameríndios, consultar Viveiros de Castro (1996:46674), Gallois (1988:166-86), Yano (2010:119), entre outros. O uso de vegetais no combate a enfermidades deve ser analisado em consonância com as noções de doenças subjacentes, aspecto esse que não é o foco desta tese, mas que é absolutamente fundamental em uma análise mais específica dos vegetais usados em processos de cura entre os ameríndios.

143 SHEPARD, G.H., Jr. "Botanies of Desire: Olfaction, Herbalism and Sexual Attraction in Two Amazonian Societies". Comunicação apresentada no encontro da American Anthropological Association, San Francisco, CA, 2000. SHEPARD, G.H., Jr. "A Sensory Ecology of Medicinal Plant Therapy in Two Amazonian Societies". American Anthropologist, 106, 2004.
} 
finalizar, entre os diversos exemplos que podemos elencar, vale mencionar os "remédios do mato" karitiana, cujos efeitos "[...] são menos por suas qualidades sensíveis do que pelo efeito de transformação que esperam da planta no momento - o 'dia', go ${ }^{144}$ - em que é usada no corpo" (Araújo 2014:76). Esses "remédios do mato" podem ser ministrados para evitar picadas de cobra e ataques de jaguar, para afastar os espíritos, produzir corpos capazes de livrar-se de ataques de inimigos, entre outras dinâmicas relacionais e aplicações (op.cit.:136-37). Dado que a noção de doença entre os ameríndios se relaciona à abertura dos corpos para o outro e a estados de vulnerabilidade - a uma ameaça de "esvaziamento do corpo" por meio da dispersão dos princípios vitais (Gallois 1988) -, os vegetais usados nas curas não atuam apenas na pessoa que está doente, eles também operam as próprias dinâmicas relacionais atreladas aos processos de cura.

O uso de partes dos vegetais para o tratamento de enfermidades entre os Yanomami é retratado extensamente por Albert, Milliken e Gomez (2009:118-31). Algumas das indicações terapêuticas associam-se ao gosto: “[...] às plantas com gosto 'ardido' (hrami) é atribuída eficácia na cura de afecções cutâneas (micoses, escabiose etc.). As plantas que apresentam um gosto 'amargo' (kõaimi) são utilizadas, de preferência, para envenenar entes patogênicos 'desconhecidos/inanimados' (yai th ëpë) no interior do corpo (como parasitas intestinais ou protozoários da malária). As plantas dotadas de um sabor 'ácido' (naxi) servem contra náusea e tonteiras, para renovar as energias e 'tirar a amargura da boca"” (op. cit.:131). A associação entre sabores e aromas exalados pelos vegetais e indicações de uso é recorrente entre os ameríndios. Observa-se, por exemplo, que, para os Karitiana, entre as "vacinas do mato" usadas para produzir pessoas sociáveis, que saibam conversar, a mais indicada é a planta tepykowot (cipó doce), cujo sabor é amargo mas torna as pessoas doces e agradáveis à convivência. De acordo com Araújo (cf. nota 2014:87), os "remédios do mato" são amargos e, mesmo para ser usados na pele, precisam ser mastigados, o que causa dissabor. Vale, portanto, ressaltar que muitos vegetais usados para a cura de doenças ou para produzir transformações nos corpos apresentam sabor amargo, ${ }^{145}$ como observado nesse item.

\footnotetext{
144 Parte dos nomes dos "remédios do mato" é formada pelo termo go, que significa "dia" (Araújo 2014:76).

${ }^{145}$ Para os Karitiana, corpos amargos promovem a agressividade e repelem doenças, e essas são características que devem estar presentes nos caçadores (Vander Velden 2008:22-23). Entre os Pano, Yano $(2010: 105 ; 20)$ marca o contraste entre o doce e o amargo, entre outros sabores, e afirma que a
} 
Entre os Caxinauá, “[...] plantas, ornamentos e certas substâncias - designados como $d a u^{146}$ - operariam, alternadamente, na condição de veneno e fortalecedor [...]” (Yano 2010:120) para abertura e fechamento da pessoa no processo de fabricação de corpos e incorporação de saberes. Essas substâncias e artefatos são capazes de estimular aptidões desejáveis e inibir comportamentos indesejáveis, como a preguiça e a avareza (op. cit.:115); podem curar e embelezar ao promover o fechamento do corpo, mas também matar ou causar algum malefício quando provocam a abertura do corpo, isto é, torná-lo leve a ponto de as vitalidades constituintes da pessoa se evadirem (op.cit.:118). Entre os efeitos do dau estão a dissimulação do corpo do caçador ao torná-lo impermeável às percepções de sua presa quando são ornamentados com pinturas corporais e a promoção da habilidade na caça ao evitar a dispersão do caçador (op.cit.:119), procedimentos compostos com dieta alimentar e indicação de descanso, por exemplo. Alguns vegetais são reconhecidos por suas capacidades venenosas e alucinógenas. Os venenos são muito presentes entre os povos amazônicos, como pode ser observado na culinária e em outros usos desenvolvidos a partir de vegetais tóxicos (Balée 1994:96-97). Os venenos, como indicado nas narrativas Piaroa, podem também estar relacionados à fertilidade, ao poder e à transformação, mas, por outro lado, podem causar a morte (Overing 2006:32). Os venenos carregam, portanto, a ambiguidade da criação e da destruição, o que vem a marcar que os vegetais podem ser usados tanto para fabricar corpos e produzir relações quanto para provocar a morte.

Outro importante aspecto dos vegetais é que muitas vezes são usados em atividades xamânicas. Entre os Yanomami, por exemplo, a inalação de pós vegetais alucinógenos é usada no processo de comunicação com os espíritos xapiripë - auxiliares de xamã com fins xamanísticos (Albert, Milliken \& Gomez 2009:114-18). Mas é o tabaco que "[...] é a substância xamanística por excelência, quase o emblema do xamã, e tem funções criadoras e transformadoras: induz o transe, cura doenças, 'benze' objetos e pessoas" (Viveiros de Castro 1987:46). Entre os Araweté, a tristeza, a saudade e a magreza conduzem a pessoa à leveza e transparência do corpo, situação na qual a

aprendizagem requer, ao mesmo tempo que promove, corpos amargos, belos, perfumados e fortes. Vale, portanto, chamar atenção para vegetais amargos na fabricação de corpos. Dos "saberes nos corpos" tratarei no capítulo IV.

${ }^{146} \mathrm{Dau}$, em sua maioria espécies vegetais, mas também ornamentos como penas, colares, pinturas corporais, entre outros, é “[...] traduzido correntemente como 'remédio"” (Yano 2010:115). 
"alma" (i) facilmente pode se desprender do corpo (Viveiros de Castro 1986:479-80). Em contraposição, o peso e a opacidade caracterizam o bem-estar e a saúde. No entanto, “[...] leveza e transparência são estados buscados no xamanismo, e só os xamãs podemdevem atingi-los sem perigo. O meio para isso é o tabaco [...], que nos 'afina', 'faz transparentes' e 'torna leves"' (op. cit.:480). O tabaco é um antialimento que pode ser usado como emético ou para provocar a comunicação com os não humanos. "O tabaco é um transformador ativo [...] o tabaco e o chocalho aray são o emblema do xamã, ambos instrumentos de contato com o mundo dos deuses e criadores [...]" (op.cit.:347). Para os Araweté, o tabaco é fundamental no processo de fazer-se xamã, capacidade que pode ser desenvolvida apenas pelos homens. ${ }^{147}$ Não há ritos de iniciação para se tornar xamã araweté, a vocação é indicada pela frequência de sonhos com jaguares, por exemplo, e, acima de tudo, pela administração regular do tabaco. "O tabaco é o emblema, o instrumento de fabricação e de operação do xamã. O treinamento xamanístico consiste em um longo ciclo de intoxicações por tabaco, até que o homem mo-kiyaha, se faça translúcido, e os deuses 'cheguem' (iwahe) até ele” (Viveiros de Castro 1986:531). ${ }^{148} \mathrm{O}$ futuro xamã, portanto, prepara seu corpo para adquirir as capacidades necessárias para estabelecer a comunicação com os seres não humanos ${ }^{149}$. O tabaco, como os venenos, tem capacidade tanto de matar quanto de fabricar corpos, como indicado entre os Araweté (Viveiros de Castro 1986:532), e também, especialmente, a de produzir experiências e atuar como índice de relações com outros seres. É um produzir-se para os outros e por meio das percepções dos outros. Não se trata de uma iniciativa em si e para si, mas de uma experiência compartilhada, por outras perspectivas, pelos outros, o que colabora para conferir a sua eficácia.

Os efeitos dos vegetais estão, em alguma medida, atrelados a características distintivas notáveis que desempenham papel proeminente no sistema de significados acionado. A

\footnotetext{
147 “[...] as mulheres não podem ser xamãs: sua alma não voltaria da viagem ao céu” (Viveiros de Castro 1986:480). "Só os homens são xamãs. As mulheres, embora sonhem e assim vejam os Mäï, não podem interagir com estes - se se atrevessem a cantar, i.e., a conversar com os deuses, eles lhes quebrariam o pescoço" (op. cit.:530).

${ }_{148}$ Para aprofundar-se sobre o xamanismo araweté, tema essencial em sua constituição, consultar Viveiros de Castro (1986:529-76).

${ }^{149}$ Como observa Gallois, os Wajãpi referem-se aos xamãs como "[...] 'aqueles que têm pajé' (i-paie, isto é, 'ele-xamã')" (1988:187), o que indica que não se é pajé, mas se tem pajé, e que para isso passam por um processo de formação, aquisição de capacidades e produção de relações. Viveiros de Castro reforça essa abordagem ao marcar que "[...] as palavras que traduzimos por 'xamã' não designam algo que se 'é', mas algo que se 'tem' - uma qualidade ou capacidade adjetiva e relacional mais que um atributo substantivo, qualidade que pode estar intensamente presente em muitas entidades não humanas" (Viveiros de Castro 2006:332).
} 
lógica do sensível como lógica das relações é indissociável da aplicação (Lima 2002:15), e, nesse sentido, os vegetais atuam como operadores de experiências e percepções e produzem de forma intencional corpos e relações sociais. Muitas vezes o equilíbrio e a estabilização são alcançados a partir da aplicação de vegetais cuja qualidade sensível destacada é similar à capacidade a ser potencializada.

Em sentido complementar, alguns vegetais têm agência e donos, características que, em alguma medida, estão atreladas à eficácia em sua aplicação, como podemos observar entre os Guarani Mbya. "No que diz respeito à utilização de plantas para fins terapêuticos, Vera é enfático em afirmar que a potência e a eficácia da planta dependem diretamente do seu dono. Se o dono não autorizar o uso, a planta não vai funcionar. Ou seja, é a partir da comunicação com o dono que este pode dotar a planta de potência para que ela sirva para a finalidade almejada" (Testa 2014:119). Assim, o que está em jogo, nesses casos, é a incorporação de qualidades de outros sujeitos. No entanto, como vimos nos capítulos anteriores, nem todos os vegetais têm donos ou são dotados de agência. Nesse sentido, Figueiredo (2010:219) conclui que, entre os Aweti, onde há espécies vegetais "com donos", como o tabaco, e "sem donos" (itat e 'ymytu), como é o caso do algodão, “[...] estamos diante de um gradiente mais que de uma oposição entre espécies com e sem dono". Enquanto remédio com dono passa "[...] a conviver com o usuário, $[. .$.$] remédios sem dono, eles aproximam a pessoa das próprias qualidades da$ espécie medicinal. Em todo caso a aproximação implica uma forma de transformação parcial em outro" (op. cit.:219) ou "[...] é o dono da espécie que aparece como agente da transformação do recluso - atestando que crescer não é função de um acúmulo de substância, mas de um acúmulo de relações. Tais relações são a tal ponto constitutivas da sua nova pessoa que sem elas o recluso não pode continuar vivo" (op. cit.:239-40), como é o caso do processo de iniciação de xamã, no qual o tabaco e os eméticos são fundamentais. Compartilham-se substâncias por uma espécie de princípio de contágio ${ }^{150}$ que transmite, nesses casos, qualidades e capacidades, como pode ser observado na relação entre as árvores e os Wajãpi no processo de constituição de pajés, que, além da relação com o dono da árvore, a qual envolve trocas de perspectivas, envolve também a transmissão de substâncias (Cabral de Oliveira 2012:73). No entanto, nem todos os vegetais usados pelos ameríndios na fabricação de corpos têm donos, o que revela que

\footnotetext{
${ }^{150}$ A difusão de substâncias e, consequentemente, de "estados" por contágio foi abordada entre os Wajãpi (Gallois 1988:159).
} 
há um leque diverso de princípios e estatutos atrelados às dinâmicas que orientam as indicações de aplicação dos vegetais pelos ameríndios. Diante da variedade de operações que envolvem relações entre elementos vegetais e outros seres, fica expressa a partir dessas interações a abertura e a incorporação de outrem, no caso, por substâncias, vitalidades ou capacidades, mais ou menos agentivas, que são fundamentais na fabricação de corpos, na cura de doenças, na constituição da vida social e, mais que tudo, na própria perpetuação de si.

\section{Carne e farinha: formas de comer e fazer para ser e estar}

Modos de preparo e consumo de alimentos são intrínsecos à produção de relações e, mais que isso, a tipos de gente. O objetivo aqui, portanto, é tomar a comensalidade como vetor de produção de relações e constituição de corporalidades (Fausto 2002:7).

Durante uma incursão à mata ${ }^{151}$ para caça de jabotis com moradores da aldeia Ta'akati, ganhei pedaços de fígado (piã) de jabotis que haviam sido caçados. Iguaria muito apreciada pelos Araweté ${ }^{152}$ e ofertada pelas famílias que cozinhavam ou assavam as outras partes do jaboti. Após a ingestão, comecei a passar muito mal e vomitei diversas vezes, coisa raríssima de acontecer. Baixava o crepúsculo, começara a escurecer, e eu completamente enjoada. No dia seguinte ofereceram-me a seiva de um cipó para ajudar na recuperação. A partir de então, eu não poderia nem sentir o cheiro de casco de jaboti assando, comida quase cotidiana tanto na aldeia quanto no acampamento. Majato ru, então, disse que eu havia passado mal por ter comido fígado de jaboti sem farinha. Essa afirmação leva a entender que as refeições compostas por carne, ou ao menos por partes de determinados tipos de caça, devem ser balanceadas com farinha, mistura que neutraliza eventuais efeitos da carne e minimiza situações de desconforto como aquela que eu tinha vivenciado. Hawutire, igualmente, explicou que comidas gordurosas como o fígado de jaboti, muito apreciadas pelos Araweté, devem ser ingeridas com muita farinha. Das situações relatadas pode ser deduzida a necessidade da composição e da mistura, ou seja, da medida das coisas na criação de corpos.

\footnotetext{
${ }^{151}$ Em fevereiro de 2014, cerca de 20 pessoas da aldeia Ta'akati acamparam na mata durante dez dias para caçar jabotis, em decorrência de um pedido de Maï, como veremos no item seguinte.

${ }^{152}$ Os Caxinauá, por exemplo, não comem fígado de jaboti por considerarem amargo (Yano 2014:114).
} 
Outra situação também me chamou a atenção: uma criança araweté passou alguns anos fora da aldeia. Com problemas de saúde ao nascer, acabou ficando no hospital de Altamira por algum tempo e, quando teve alta, por não estar plenamente curada, ou por algum outro motivo, ficou sob os cuidados de famílias de não índios na cidade. Ao retornar à aldeia, teve certa dificuldade de adaptação especialmente pelo fato de não se habituar ao modo araweté de comer, recusando, por exemplo, jaboti assado, o que gerou, por parte de sua mãe, dificuldade de reconhecer a criança como Araweté ${ }^{153}$.

A dieta de carne é imprescindível para os Araweté, máxima válida para ameríndios de modo geral (Yano 2014:117-18). Os Araweté diariamente organizam caçadas individuais ou coletivas com o objetivo de abastecer as refeições com carne (haa). ${ }^{154} \mathrm{~A}$ preferência é sempre por animais gordos, ${ }^{155}$ ou seja, com bastante gordura, entre eles jaboti, queixada, cotia, mutum, jacu, tatu e arara. Este é, inclusive, um dos motivos de não se interessarem pela caça e tampouco por comer filhotes e carnes magras, que indicam que o animal está com alguma doença. A carne não pode ser ingerida crua, devendo ser cozida ou assada. Em ocasiões com grande quantidade de carne, no caso de uma caçada extraordinariamente abundante, a opção é pelo moqueado, para conservá-la por mais tempo. A limpeza da carne na beira do rio e sua distribuição são feitas pelo homem ao chegar na aldeia após a caçada no final do dia, evento que, no mínimo, mobiliza a atenção de todos. Cabe ao homem mais velho na aldeia destrinchar a caça, tirar as vísceras, separar as partes nobres e fazer a distribuição. Os homens distribuem a carne para seus sogros e progenitores em primeiro lugar, e depois, se houver quantidade suficiente, para parentes próximos ou aqueles com quem costumam efetuar as trocas. A distribuição de carne de caça é corriqueira entre os Araweté; como diz Viveiros de Castro (1986:154), “[...] a generosidade alimentar é um valor essencial da sociedade Araweté". Às mulheres cabe carregar e preparar as carnes.

Da roça, as culturas principais são awatfi (milho) e madia (mandioca), como indicado anteriormente. A maioria das famílias possui duas roças, sendo uma de milho e outra de

\footnotetext{
${ }^{153}$ Situação semelhante foi relatada entre os Parakanã (Fausto 2002:15-16).

154 Em Araweté, carne é haa, mas também haa me'e, que pode ser traduzido por "é gordo" (Solano 2009:319), ou ainda he raa, que pode ser traduzido por "gordura de mim" (op. cit.:103).

${ }^{155}$ A apreciação de carnes gordas ocorre entre outros ameríndios, como os Caxinauá, entre os quais as carnes mais apreciadas por esse motivo são: "macaco prego (xinu), da anta (awa), do caititu, também conhecido como pecari (hunu yawa), e da queixada de focinho branco (yawa kuin)" (Yano 2014:108).
} 
mandioca, onde também são plantados cará, batata-doce e outros produtos. ${ }^{156} \mathrm{O}$ milho pode ser consumido assado, como farinha ou mingau doce e azedo. "O milho pilado é a base do iy $\underline{i}$, caldo grosso de carne cozida que acompanha certos tipos de caça; com a paçoca se faz o namo pi re, pirão. Esta paçoca, feita de milho maduro, torrado e pilado, é a farinha básica da dieta Araweté, sendo consumida durante nove meses do ano. $\mathrm{O}$ cauim do milho azedo ou alcoólico ( $k \tilde{a}$ '’ ${ }^{\prime} d \underline{a}$ ), por sua vez, é o foco da maior cerimônia Araweté [...]" (Viveiros de Castro 1986:152). Antes de excursões de caça, as mulheres vão para a roça colher milho para ser torrado e pilado, preparado que denominam awat $f i$ mepi (paçoca de milho). Noras jovens e sem filhos encarregam-se de preparar a farinha da sogra. Também preparam e levam farinha de mandioca $(u t j i)$, a depender da época e da maturação do cultivo para colheita. Atualmente, ao menos durante o período em que estive em campo, apesar de a mandioca ser cultivada e beneficiada pelos Araweté, em grande medida ela é adquirida por meio de variadas formas de trocas, tanto entre famílias araweté como junto aos ribeirinhos moradores do entorno da terra indígena. Mesmo que a caçada seja breve, ou seja, que ocorra apenas durante parte de um período do dia, principalmente se se contar com a presença de mulheres e crianças, os caçadores carregarão consigo uma porção de farinha a ser consumida aos poucos durante a jornada. "A caça define um espaço masculino, e a roça, enquanto roça de milho, um espaço feminino [...]” (op. cit.:153). Nota-se essa complementaridade também no caso da família que sai para caçar e deixa filhos pequenos sob os cuidados de outras mulheres: "[...] pode pedir a outra que prepare alguma quantidade de farinha de milho de que possa usar imediatamente ao voltar. Em troca desse serviço - feito pelas mulheres -, os excursionistas lhes dão alguns jabotis ou outra carne que trouxerem da mata. A família que viajou assume, assim, a posição masculina, de provedora de carne; a que ficou, a posição feminina, de processadora de milho" (op. cit.:295).

Cada família nuclear produz o próprio fogo para preparar a comida, de preferência o fogo deve permanecer sempre aceso ou em brasa. Uma das primeiras coisas a fazer, seja no retorno à aldeia após passar um período fora, seja em um acampamento de caça, é acender o fogo, atividade conduzida pelas mulheres. Em geral, sobretudo em épocas de seca, a comida é preparada e consumida no terreiro em frente à casa, situação que sinaliza uma abertura para receber visitas. Quando a comida é escassa ou o casal quer

\footnotetext{
156 Para obter mais informações sobre atividades agrícolas, caça, pesca e coleta entre os Araweté, consultar Faria (2007:133-161).
} 
ficar mais reservado, a casa é o lugar de preparo e consumo das refeições. "Nas primeiras horas da noite começa o período de máxima sociabilidade: a 'ronda gastronômica' de pátio em pátio, para o consumo da produção do dia" (Viveiros de Castro 1986:290). O chamado, a depender da disponibilidade de carne, é feito pelos homens - em geral o progenitor de uma família extensa ou de uma família nuclear com filhos; casais novos tendem a partilhar o fogo dos pais ou sogros -, que anunciam em voz alta os nomes das pessoas e famílias convidadas. Moradores da seção residencial ${ }^{157}$ ou parentes próximos são, então, convidados a partilhar a refeição. A carne é oferecida pelo anfitrião, mas a farinha deve ser levada pelas famílias convidadas. Quando o alimento é cozido, o caldo é comido com farinha em recipientes separados por gênero; no caso de haver mais de uma família nuclear, separam-se em um grupo de homens e outro de mulheres. "É preciso notar que os Araweté, contudo, não elaboram estruturas fixas de troca alimentar (do tipo 'pagamento em alimento' etc). que marcassem simbolicamente papéis e posições na estrutura social. Aqui como em outros domínios, a ideologia da mutualidade (cuja outra face é a competição) prevalece sobre o fato da reciprocidade (e a exigência da cooperação), impedindo sua regulação cerimonial e fixa. A repetição metonímica - comer o mesmo, de casa em casa - prevalece sobre qualquer complementaridade metafórica" (Viveiros de Castro 1986:293; grifos do autor). ${ }^{158}$

A refeição composta por carne e farinha ${ }^{159}$ é caracterizada como uma "[...] refeição típica e ideal Araweté" (Viveiros de Castro 1986:163), principalmente se a farinha for de milho e a carne, de jaboti. "[...] a carne é o alimento mais valorizado, do ponto de vista do paladar e da nutrição. Uma refeição sem carne é motivo de constrangimento e depressão psicológica - e, se uma refeição sem milho é imprópria, uma refeição sem carne é insubstancial. Assim, é possível ter 'fome' (ho'imã ) em meio a uma abundância de milho, batatas etc.” (op.cit.:164). A gordura, como dito acima, é uma parte muito

\footnotetext{
157 Viveiros de Castro (1986:289) descreve contextos de interação social em termos inclusivos, tendo como referência a aldeia, como segue: aldeia, pátio da seção residencial, terreiro-fogo doméstico e casa. As seções residenciais são compostas por casas conjugais da família extensa, que envolve formas cooperativas de produção e consumo e tende inclusive a organizar caçadas conjuntas. No caso de "grupos de comer", destacam-se sogros, progenitores, filhos casados e moradores da mesma seção residencial (op. cit.:295-96).

${ }^{158}$ Há alguns trabalhos que aproximam sexo e carne ou sexo e caça (Gow 1989 et alii), inclusive entre os Araweté. Essa é uma aproximação corrente que desloca a atenção da circulação de alimentos de uma esfera econômica para um campo simbólico e da volição.

159 Essa mistura, também pode ser observada a partir da dinâmica da produção e de formas de organização, foco que não foi privilegiado nesse item, mas que também pode ser explorado conforme discussão de Viveiros de Castro (1986:270-72) sobre a dinâmica entre mata e aldeia.
} 
apreciada nas carnes. Certa vez, quando da caçada de um tatu muito grande (tatu howihã), todas as famílias presentes foram convidadas pelo anfitrião a saborear a gordura presa na carapaça do tatu - a gordura era retirada com os dedos -, a primeira iguaria servida. A carne foi assada durante mais um tempo antes de ser distribuída aos homens das famílias nucleares próximas, como filhos e genros. Esse tatu tinha sido caçado (ou coletado, pelo fato de não ter sido usada arma de fogo para sua apreensão) pelo genro do progenitor da família extensa que estava no acampamento, que assim presenteou o sogro. O preparo do tatu foi feito principalmente por sua sogra e filhos menores. O comer junto, segundo Tiñarai du, faz aprender a ser Araweté. Comer junto, ou seja, comer as mesmas coisas e do mesmo jeito, e a partilha de carne contribuem, portanto, para construir corpos semelhantes e produzir parentes ou, no mínimo, relações próximas. A valorização do comer junto, especialmente carne de caça, aparece também entre os Caxinauá. "Prestigiada e saborosa, disseram-me os caxinauá que a carne de caça (yuinaka nami) é por excelência aquilo que se come junto [...]. Jamais deve ser ingerida às escondidas ou sozinho (mesti)" (Yano 2014:118). Comer junto, nesse caso, leva ao estado de alegria; já a privação da carne, à solidão e à tristeza. "A partilha da carne e a comensalidade não apenas marcam as relações entre parentes como também as produzem. Comer como alguém e com alguém é um forte vetor de identidade, assim como abster-se por ou com alguém. A partilha do alimento e do código culinário fabrica, portanto, pessoas da mesma espécie" (Fausto 2002:15). Dar de comer, como demonstrado entre os Kanamari, não abarca apenas aspectos de subsistência, mas também relações assimétricas entre aquele que alimenta e aquele que é alimentado, vindo a criar uma relação de dependência, da "pessoa que alimenta", e afeto fundamental para a criação do vínculo e, assim, para a própria relação de parentesco entre as pessoas - que, nesse caso, é em grande medida fabricada socialmente -, mas não se restringindo a ela (Costa 2013:476, 477, 479).

Assim como outros povos amazônicos, os Araweté gostam de carne gorda. "O termo Araweté próprio para 'gordura' é cirâa. A noção de cewe refere-se mais a uma ideia de 'substancialidade' ou força nutritiva, que no caso da carne animal depende da camada de gordura. Outro alimento é dito cewe : o mel. [...] A esta categoria de alimentos se contrapõem os alimentos he 'e, 'doces', como a banana, o mamão, a batata, o abacaxi e o cauim doce; os alimentos 'da, "azedos", como o cauim alcoólico, o açaí e o cará; os alimentos hati, 'duros', como as farinhas de milho; e as castanhas do pará e do babaçu” 
(Viveiros de Castro 1986:165; grifos do autor). As características, combinações e a própria interdição de alguns alimentos são fundamentais na constituição de corpos, como relata Yano (2010:52) a partir de estudos feitos entre os Caxinauá; a carne é mais saborosa quanto mais gordura tiver, e sua acumulação contribui para a maturação da pessoa. Por outro lado, alguns atributos ou misturas de alimentos pode fazer mal. Para os Araweté, comer peixe com alimentos considerados doces faz mal, pode dar dor de barriga. Durante a gestação, as mulheres “[...] não devem comer anta, pois seu espírito pisotearia a barriga da mãe; ou usar de milho cujo cesto de transporte, vindo da roça, se partiu; ou comer fêmeas grávidas de animais. Tudo isso é abortivo. Não devem ainda comer coxas de veado e mutum, o que enfraqueceria as pernas da criança" (Viveiros de Castro 1996:441). No período pós-parto, diversas são as restrições alimentares, especialmente com relação à ingestão de carnes de algumas aves, poraquê, espécies de jaboti, tracajá, ovo de tracajá, entre outras, caso contrário o bebê ficará magro. Até o bebê andar e falar, os progenitores não devem comer jabotis aleijados. "Todas essas carnes [...] produzem um só efeito: o hapí, a 'queima' da criança, que resulta em sua morte" (op. cit.:445). Por isso, os genitores, em especial, devem abster-se de fazer certas atividades, como carregar peso ou ir à mata, e de comer alguns alimentos. "O objeto de toda a abstinência (koako hã) são coisas ditas me'e a'o: ações perigosas dos pais em couvade, certos alimentos (especialmente carnes), e o sexo. Me'e a'o, 'coisas- $a$ 'o', traz a mesma raiz do conceito de espectro ou espírito - - $\underline{a}$ 'o we - e do verbo para 'saudade', mo- $\underline{a}$ 'o (op.cit.:467; grifos do autor). Algumas carnes, como as de veado (arapuha), anta (tapi'i), tatu, guariba, entre outras, liberam o 'espírito ha 'o we do animal', o que pode levar ao enfraquecimento, a dores e até à morte" (op.cit.:468), razão pela qual são evitadas ou comidas com cautela. Quando o filho está doente, os pais não podem comer veado para não ficarem fracos e com dores nos ossos. Não se pode fotografar anta, caso contrário, dizem os Araweté, "a máquina queima". Criança que mama não pode comer carne de poraquê (puretfe) para não ficar doente da barriga; já seus genitores estão liberados. Não se deve pronunciar o nome daqueles animais, tampouco fazer comentários sobre suas características. Por outro lado, os Araweté não comem onça (nã), coelho (tapirihi), lobo (micô) e jacaré (jaratfe), pois consideram que comê-los faz mal à saúde. Esses seriam, como enfatiza Garcia, para os Awá, “o grupo de alimentos perigosos" (2010:130), variável conforme o histórico dos grupos e a disponibilidade de alimentos nas regiões onde vivem (op.cit.:132). Os Aweti, por sua vez, consideram-se fracos em relação ao povo do tempo de kwaza - Kwat e Taty, Sol e Lua -, que comia de 
tudo e não ficava doente. Hoje são suscetíveis a ficar tsaratu, que “[...] significa ser afetado malignamente pela comida, ser alterado, à revelia, pelo que se comeu. A gordura, o cheiro pyly'u, o tamanho e o fato de ser mais ou menos selvagem são fatores que determinam a potência patogênica de um alimento" (Figueiredo 2010:198). Ser afetado por comer carne ocorre, então, entre outros fatores, por sua potência agentiva. Vegetais, como demonstrado anteriormente, carregam certa potência agentiva, se é que podemos denominar assim, mas, nesse sentido, Fausto (2002:17) indica que há um gradiente de agentividade em que os vegetais seriam classificados como menos agentivos, e os cuidados relativos à alimentação estariam relacionados a essa característica. A culinária seria, portanto, uma maneira de desagentivizar o alimento, em especial a carne, uma vez que seu consumo se configuracomo o ato de "comer alguém" (Fausto 2002:16-17). Dessa forma, bloquearia a subjetividade do animal caçado. Como observa Fausto em relação às restrições alimentares, “[...] comer é uma atividade particularmente delicada, pois pode converter-se em uma relação social entre sujeitos" (op.cit.:22). Além disso, adquirir hábitos ou modos de comer de outros pode ser perigoso por provocar, eventualmente, a transformação de si em outro (Garcia 2010:113, 129).

A boa alimentação, por sua vez, contribui para desenvolver características sociais desejáveis. Os Yudjá buscam "[...] aquela mansidão (um misto de confiança e tranquilidade) que os mais diversos filhotes e o bebê (bem alimentado) demonstram diante dos humanos e [...] a gratificação que a simples observação dessa mansidão desperta. Em uma palavra, ser sociável é não estar amedrontado e violento" (Lima 1996: 28). Nesse sentido, a transmissão de qualidades valorizadas dos animais caçados pode ocorrer pelo seu consumo. "Para os Aweti, alimentar-se é apropriar-se de diferenças, para o bem ou para o mal. A nádega da anta, ela não está dada no corpo do comedor de anta, ela será apropriada por ele. Ou a juventude do macaco. Nisso a alimentação não se distingue de diversos outros procedimentos curativos ou voltados para a aquisição de força e beleza [...]. Ao comer, assim como ao usar determinadas substâncias de origem vegetal ou animal, a pessoa se apropria de qualidades físicas e morais daquilo que é ingerido, ou com que entrou em contato. [...] Uma lógica subjacente a todos estes fatos me parece ser a de que quase tudo que uma pessoa faz na vida implica uma relação simultaneamente produtiva e perigosa" (Figueiredo 2010:201). As práticas alimentares podem, portanto, provocar transformações pelo 
consumo, principalmente de carnes, cujos animais de origem são tomados como fonte de capacidades e intencionalidades, nesses e em outros contextos ameríndios. O consumo dos alimentos, por certo, deve ser moderado e ocorrer de forma adequada (Yano 2010:54). O modo, portanto, como as relações são estabelecidas influencia no processo de fabricação de corpos. A abertura e o fechamento ao outro revelam que a constituição de corpos ocorre por relações continuadas entre sujeitos, as quais devem ser dosadas para ser adequadas e assim evitar o perigo de um sujeito transformar-se em outro.

A mistura de carne e farinha ${ }^{160}$, para além de aspectos nutricionais, pode ser pensada em termos de efeitos do consumo de alimentos nos corpos, que podem decorrer tanto da composição entre sabores, aromas e consistência dos alimentos como do balanceamento do consumo entre carne de caça e produtos vegetais. Entre os Caxinauá, "[...] a carne de caça, ao contrário, é da ordem da mistura (xadabu): à exigência de mesclá-la aos vegetais (yunu) soma-se o fato de que as pessoas saboreiam-na juntas (itxa), promovendo, ao final, uma saciedade coletiva. Entre comer sozinho (mesti) e comer junto (itxaxun), o gradiente de pessoas envolvidas na refeição presta-se, a meu ver, àquele mesmo propósito de modular os sabores (nue) das comidas e seus efeitos nos corpos. [...] a partilha da carne faz circular os atributos do animal entre as pessoas, fazendo-as mais fortes, ao mesmo tempo que abranda sua potência para que não seja em demasia” (Yano 2014:118-19). Observa-se que “[...] a saciedade plena para eles decorre da mistura adequada da carne de caça (yuinaka) com os vegetais (yunu), cujo grau de elaboração não apenas suspende a passagem natural e inevitável da crueza à putrefação, mas, sobretudo, muito diz acerca da culinária caxinauá [...]” (op.cit.:111), em que os perigos decorrentes da ingestão de carne estão relacionados a sua distância do fogo. Os alimentos devem estar bem cozidos, e, no caso da carne, não deve haver qualquer vestígio de sangue, como para os Araweté. Assim, sobre a complementaridade entre carne e farinha nas refeições araweté, apreende-se que essa mistura remete não a uma

\footnotetext{
${ }^{160}$ Carne e farinha é também uma mistura fundamental entre os seringueiros, mais especificamente os do Alto Juruá, no Acre. A farinha de mandioca, de produção doméstica, é fundamental tanto nas refeições diárias quanto para acompanhar outros alimentos, como frutas e bebidas; a presença de carne, nesse caso de animais silvestres, nas refeições é sinal de fartura e decorre de relações sociais e de relações de prestígio. No entanto, a percepção dos ribeirinhos com relação à caça e à farinha em termos de relações de criação ocorre a partir de lógicas e valores bem diferentes daqueles dos ameríndios. Aquilo que se cria e se produz pode ser consumido e comercializado; aquilo que não se cria, como carne de caça, pode ser apenas consumido (Postigo 2010:155-87).
} 
dinâmica de equilíbrio entre os gêneros, dado que com maior ou menor intensidade homens e mulheres participam dessas atividades, se não na caça propriamente dita, mas não em todas as situações, no preparo da roça, na colheita e na própria transformação dos alimentos. No caso da carne e da farinha de mandioca, por exemplo, ocorre a retirada de elementos perigosos, como o sangue da carne e o líquido extraído da massa de mandioca, altamente tóxico. Dessa forma, tornam-se apropriadas para consumo humano. Por outro lado, a gordura da carne contrapõe-se às características da farinha, que, após ser ralada e prensada (no caso da mandioca), ou pilada (no caso do milho), é torrada com o objetivo de retirar a umidade, tornando-se seca e de consistência mais dura, balanceamento que acaba por manter um equilíbrio sadio na constituição de corpos nem demasiado moles, nem excessivamente rijos. Essa equação pode ser expressa pela relação entre comida gordurosa e comida seca/dura. Se entre os Araweté o sangue e as coisas cruas não despertam rigorosas restrições, para os Caxinauá a carne gordurosa, associada a animais de sangue forte, contrapõe-se a carnes mais leves, como a de peixe, de sangue fraco, cuja ingestão seria menos perigosa para o equilíbrio do sangue no corpo. Segundo Yano (2014), as características imputadas ao sangue da carne consumida associam-se a outros atributos que contribuem com o processo de fabricação de corpos. "A carne de anta ( $a w a)$ não lhes é saborosa (nuepei) somente porque é gorda (xeniwa) e temperada (bata), mas porque ela se constitui do sangue (himi) e do pensamento (xinan) de um animal que, aos olhos caxinauá, é robusto e forte (kuxi). São essas qualidades que homens e mulheres caxinauá almejam tomar para si” (Yano 2014:116). Assim, saber compor características sensíveis e outras qualidades atribuídas aos alimentos, prática em que a mistura de carne e farinha, principalmente, parece determinante, é fundamental na constituição de corpos belos, fortes e saudáveis e de socialidades em que o comer junto cria relações próximas.

A existência e a consciência de si é também produzida, portanto, na dinâmica da comensalidade, uma vez que alimentar-se ou ser alimentado é estar em relação. Essas relações carregam ambiguidade, por isso devem-se tomar os devidos cuidados e precauções ao alimentar-se, bem como agir de modo adequado, para manter - entendase produzir - o estado de boa saúde e vigor e as características que garantam que, na produção e consumo dos alimentos, ao apropriar-se do outro, não irão se transformar em outrem. Para andar com segurança nas florestas, problemática central nesta tese, é, portanto, necessário manejar as boas regras imputadas à comensalidade tanto para 
produzir corpos belos e fortes e estar preparado para essa atividade quanto para estabelecer relações adequadas e assim evitar maiores perigos.

\section{Caçadores e comedores de jabotis}

A caça dos jabotis pelos Araweté envolve relações entre homens e jabotis (jati), entre jabotis e árvores, entre casais e/ou grupos locais e entre homens e outros seres.

Sair para a mata, para caçar, é uma atividade cotidiana dos Araweté, que pode acontecer em pequenos grupos compostos por membros das famílias conjugais, cunhados (afins do mesmo sexo) ou irmãos; em excursões organizadas entre seções residenciais formadas, em geral, por famílias extensas uxorilocais (forma de residência pós-marital na qual o homem passa a residir junto à família da mulher); por grupos de irmãos casados; ou entre pares de casais recém-casados (Viveiros de Castro 1986:288), relação denominada apihi-pihã e marcada pela troca temporária de cônjuges. É sobretudo a partir desses arranjos que os Araweté circulam pelas matas e empreendem a caçada de jabotis, bastante recorrente, em especial na estação chuvosa (amï, "chuva") - durante o verão, quando o rio está mais seco, é mais difícil encontrar jabotis -, e das mais apreciadas pelos Araweté. Aliás, “[...] os jabotis e tatus são menos caçados que 'coletados', visto que não exigem armas" (op. cit.:154). Os jabotis são desejados pelos homens, pelos deuses, Maï e os mortos, que são trazidos à camada terrestre na ocasião do consumo desses alimentos como parte de um sistema ritual central e quase ordinário na vida dos Araweté. Maï e os mortos habitam a primeira camada celeste.

Como apresentado anteriormente, não existe na língua e no pensamento araweté uma unidade taxionômica para a nossa categoria de "animal", embora haja algumas categorias genéricas, como peixes (pidã) e aves (irã). Diversas características podem definir as relações entre os animais, mas uma distinção fundamental, também aplicada a outras categorias de seres, como os vegetais, é entre os seres que "sempre existiram", como os jabotis - ditos muito antigos -, algumas espécies de peixes e insetos e aqueles que foram criados - no sentido de "colocados" -, e entre eles estão gavião, urubu, onça, guariba, veado, jacu, paca, tatu e outros (Viveiros de Castro 1986:223-24).

Os animais eram humanos antigamente. Em uma vingança o nã-maï (deus-onça) 
transformou os humanos em animais (por meio do agitar de um aray, chocalho). Após a transformação, o deus-onça subiu ao céu e levou a maior parte da população animal criada. Os animais restantes na terra são os "abandonados", que nunca subirão ao céu. Os animais da terra são da terra, e os do céu são do céu. Assim, na camada celeste, existem os animais caçados e comidos pelos deuses ${ }^{161}$ e aqueles que não são de comer, pois são animais de estimação dos deuses, aparecem nos cantos dos xamãs e são frequentemente identificados pelos sufixos açu ou uhu, "grande", e yo, "amarelo". Esse parece ser o caso dos jabotis, que estão na camada celeste e são descritos pelos Araweté como muito grandes (jati uhu). Madai ru disse que no Mai (camada celeste) tem jaboti grande criado por Maï, motivo pelo qual não pode comê-lo. Naña nu contou que Maï não come jaboti grande porque faz mal para a saúde. Relatam também que Maï quer diversificar sua alimentação, pois enjoa das caças que há no Mai, sendo esse um dos motivos para quererem comer os jabotis que estão na camada terrestre, além de estarem com fome e de gostarem de comer jaboti. Os Araweté também dizem que Maï fica só namorando e não procura jaboti (jati). Em suma, embora os Maï empreendam caçadas na camada celeste, eles requerem aos homens a realização de banquetes rituais. Um morto recente (transformado em Mai) pode manifestar seu desejo em sonho a um parente próximo, o qual se tornará o tenetãmõ - posição extremamente discreta que indica aquele que "vai à frente" nas caçadas -, ou os Maï podem revelar-se aos pajés.

O consumo dos alimentos pelos Maï e os mortos não ocorre por “[...] motivo de apaziguamento, propiciação ou coisa semelhante. Os deuses vêm porque vêm, porque os Araweté gostam que eles venham - gostam de ouvir seus cantos quando descem à terra, e ouvir o que eles e os mortos falam para os viventes" (Viveiros de Castro 1986:235), mas a posição de “comedores" nos banquetes divinos não deixa de indicar “[...] a posição canibal dos deuses" (op.cit.:235). Alguns alimentos são classificados como perigosos, ${ }^{162}$ como é o caso dos jabotis, por conter "flechas" que são dispersadas

\footnotetext{
${ }^{161}$ Os Araweté dizem que no céu não são encontrados queixadas, que estão apenas na camada terrestre, tatus e quatis - alimento predileto dos Ani (cf. Viveiros de Castro 1986:487) -, mas há a presença de tucanos - totinoho e jacu, entre outros.

${ }^{162}$ Kuniawi du (Kupire), cacique da aldeia Aradjyti, disse-me que o pajé lhe contara que anta e veado fazem mal, por isso não pode comer, evitam; se comerem veado e anta, receberão uma espécie de "choque". "Os perigos místicos associados a determinadas espécies de alimento remetem a outro sistema, que é o das 'flechas' contidas na carne dos jabotis e no mel, o da 'dor' contida nos peixes e no cauim, e o do 'espírito' da anta e do veado. Note-se que todas essas coisas são também 'comida dos deuses' - e que o xamanismo sobre elas, que traz as divindades para o festim, é duplicado por um xamanismo de neutralização destes perigos, por meios "mágicos" (i.e., sem intervenção dos deuses) (Viveiros de Castro 1986:235-36).
} 
pelos xamãs nas cerimônias coletivas. No dia a dia, não há e tampouco é necessário empreender qualquer ação no sentido de dispersar as "flechas" contidas na carne de jaboti. Viveiros de Castro sugere que "[...] se tratava, antes, de tornar o produto aceitável para o consumo divino que apenas para o humano" (op. cit.:235). Karapi hi, inclusive, disse-me que para Mä̈ comer jaboti tem que fazer a festa do jaboti (o que chamou em português de "maracá" ou jati peyo), senão corre o risco de ser flechado. “Os jabotis, como o mel, têm 'flechas' farpeadas invisíveis, que precisam ser dispersadas pelos xamãs; mas apenas os moqueados têm isso, pois elas residem nos cascos. Os jabotis consumidos cozidos têm somente a 'coisa xamânica' (i-peye we), menos perigosa" (op. cit.:357). Se "flechas" ou "coisa xamânica", o fato é que a carne de jaboti precisa ser desagentivizada e neutralizada na pajelança para o consumo, principalmente, dos Maï, que "[...] comem xamanisticamente a $i$ dos alimentos, sua ‘imagem', enquanto os humanos comem a ‘carne' (ha'a pe)” (1986:496).

Assim, alguns deuses celestes são comedores (ã) de determinados alimentos e são trazidos à terra pelos xamãs em ocasião de consumo cerimonial desses produtos (Viveiros de Castro 1986:233). Maï e os mortos manifestam-se nos cantos dos pajés e revelam sua vontade de comer, nesse caso, jabotis. Os mortos ${ }^{163}$ vêm por cerca de duas décadas à terra nos cantos dos pajés e, por esse período, participam de banquetes rituais. He re pe rin é o termo usado para indicar a via principal pela qual os xamãs (peye) conduzem os mortos e os Maï à terra para passear e participar dos banquetes cerimoniais, nos quais os alimentos são oferecidos aos Maï antes de serem consumidos pelos humanos. "Cada alimento da classe definida como 'comida dos deuses' (Mại demi-do) - que coincide com os alimentos ditos xamanizáveis (ipeyo pi) - tem divindades específicas associadas" (Viveiros de Castro 1986:233). “[...] os deuses tomam do alimento ipeye hã iwe, 'mediante o poder xamânico', deixando intacta sua substância. Não se trata, portanto, de comensalidade, mas de prelibação divina do esforço produtivo da comunidade - isto é, de uma estrutura sacrificial. As 'comidas dos deuses' são sempre aquelas que resultam da produção e consumo do grupo local como um todo; a noção se refere assim menos a certas espécies de alimento que à forma coletiva de produzi-los e consumi-los" (op. cit.:234; grifos do autor). Essas ocasiões de

\footnotetext{
${ }^{163}$ A morte divide a pessoa em um espectro terrestre, que assombra os vivos, e um princípio vital, alma celeste que é devorada pelos Maï ao chegar ao céu, sendo depois ressuscitada e transformada em um ser eternamente jovem.
} 
produção e consumo coletivo são os "[...] únicos tipos de situação em que a aldeia ou grupo local Araweté emerge como unidade" (op. cit.:236), em contraste com deuses e mortos. Majato ru disse-me que Maï tem que autorizar a realização da festa, comparando à autorização que tenho que obter da Funai (Fundação Nacional do Índio) para poder fazer pesquisa em Terra Indígena. Explicou que essa autorização não decorre de eventual relação de maestria entre Maï e jabotis. As festas coletivas são, exceto a do cauim azedo, ${ }^{164}$ ligadas a Maï, o que, de certa forma, marca a oposição entre homens e deuses, assinalando a diferença entre humanos e outros - inimigos, deuses e mortos (Viveiros de Castro 1986:363). Aqui, no entanto, é fundamental focar, para além do aspecto interpretado por Viveiros de Castro como uma "estrutura sacrificial", nos arranjos e conexões estabelecidas, no tipo de alimento produzido e em sua dinâmica de caça, coleta e produção, que indicam modos de circulação nas matas e dimensões nas quais são estabelecidas relações sociais.

O combinado de uma caçada para atender ao pedido dos deuses e mortos é feito sutilmente em conversas no pátio, à noite ou de manhã, quando as pessoas circulam pelas casas para tomar café. O movimento na aldeia não muda, e após algumas horas, quando parece que nada vai acontecer, começam os preparativos para a partida por meio da iniciativa "daqueles que começam", os tenetãmõ. Estes são os responsáveis por convidar para a caçada, que, no caso de banquetes rituais, conta sempre com a presença de diversas famílias da aldeia. "O pajé convida a comunidade para pegar jaboti, para fazer maracá com ele, aí convida”, disse-me um araweté. Em pouco tempo, restam na aldeia apenas velhos, crianças e mulheres grávidas. O grupo, ou os diversos grupos, segue para o local da caçada carregando armas, terçados, petin (fumo) e farinha e, muitas vezes, pintados de urucum. O tenetãmõ é, em geral, parente próximo do Maï (exmorto) que manifestou a vontade de comer jaboti, podendo também ser um pajé que recebeu o pedido de $M a \ddot{i}$, e tem a atribuição de indicar os locais e tempos das caçadas. Os tenetãmõ não têm como incumbência oferecer comida ou qualquer outra coisa àqueles que participarem da caçada, pois o banquete cerimonial é dedicado ao consumo de Maï. Os tenetãmõ podem organizar caçadas tanto a partir de acampamentos distantes das aldeias como em locais mais próximos com retorno para casa no final da tarde.

\footnotetext{
${ }^{164}$ Nessa festa não cantam o que denominam músicas de Mä̈, e tampouco ela é realizada em decorrência de um pedido de Maï. Para mais informações sobre a festa do cauim azedo, consultar Viveiros de Castro (1986:266-67; 327-51).
} 
Tanto nos acampamentos quanto nas caçadas que partem diariamente das aldeias o movimento cessará apenas quando conseguirem acumular a quantidade de jabotis suficiente para organizar a festa. Quando vão caçar jaboti, os Araweté dizem: 'jati het $\left[a\right.$ '. Sendo he pronome pessoal da primeira pessoa do singular; e, h-et $\int a$, pode ser traduzido por "vê-lo" (Solano 2009:446;103). Jati h-etla significa, portanto, "ver/procurar/achar/pegar jaboti", sentido que é muito acionado na caça, principalmente na caça de jaboti.

A caçada é uma atividade com trilhas, intenções e formato conhecidos por todos, e conta com a possibilidade de improvisos pela composição do grupo e pela constante redefinição dos caminhos à procura das presas. A cada parada para descanso, pode ocorrer o encontro de uma parte ou de todo o grupo, novos arranjos são compostos e novos trilhas desenhadas, dependendo do que foi caçado, das pistas apresentadas, do desejo de estar apenas com o cônjuge ou da disposição para continuar.

Quando as caçadas envolvem algumas famílias conjugais, partem de junto da aldeia até o local definido para a caçada. Esperam a chegada de todos, em geral, em algum tipo de clareira. No começo da entrada nas matas, as famílias caminham juntas, mas logo se dispersam. Os casais e/ou famílias conjugais se dispersam em caminhos aparentemente mal marcados, imperceptíveis a um leigo, mas muitas vezes já desenhados, percorridos e apropriados pelos cônjuges, que circulam de forma recorrente nas florestas. Assim, o marido com uma passada ritmada segue à frente empunhando uma arma, sua esposa o acompanha desbastando com terçado paus e matos que dificultam a passagem; seguem marcando os locais por onde passam, sinais esses que garantem que não ficarão perdidos nas matas.

As frutas dispersas no chão, os diferentes tipos de árvores e os alagados marcam os caminhos e fornecem pistas dos seres que estão por perto. Identificam comida de anta, veado e jaboti. Caroço de cajá comido é sinal da presença de jaboti; fezes de anta e caroço de bacaba comido é sinal de que anta passou por ali. O ciclo de produção das frutas indica a presença e a proximidade de certos animais. A moita de um arbusto que denominam banana brava indica a plantação ou, como dizem, o milho de Maï. Um açaizal evidencia a presença do seu dono, Ani. Um cheiro fétido indica a passagem de uma manada de queixada. Um tipo de estrondo é associado a um casal de antas, e 
rugidos, a um bando de guaribas. Os marcos topográficos servem, sem dúvida, de referenciais, mas estão sempre atrelados aos seres que nele habitam ou que por ele circulam.

As árvores, especialmente as frutíferas, são importantes marcadores que orientam a circulação pelas matas. Os Araweté buscam sempre avistar, e assim abrir caminhos para alcançar, as árvores que fornecem frutos comidos pelos jabotis, como gulosa e bucha, entre outros. Os jabotis, segundo os Araweté, são atraídos pelos cheiros de determinadas frutas que são suas fontes alimentares, locais indicados como sendo "florestas dos jabotis". Dizem que o jabotis é criado pelas e nas "florestas e frutas dele"; é recorrente a fala dos Araweté de que os jabotis se criam sozinhos no mato, e esse entendimento é fundamental para a classificação dos jabotis como "seres que sempre existiram". Essa noção de criar não remete ao conceito de dono no sentido de controle e domínio, mas a uma relação mútua entre o que é comido e o ser que come; jabotis e árvores se criam mutuamente, e nesse sentido não há apenas uma relação funcional, mas também atravessada por componentes afetivos e sensoriais, sendo o aroma um vetor fundamental no estabelecimento dessa relação. Os jabotis fazem sua morada entre galhos secos, denominados kuperin, ou buracos cavados na terra no entorno dessas árvores, locais que também são referências na procura dos jabotis.

De volta à caça ou coleta de jabotis, enquanto os maridos seguem à frente atentos a todos os tipos de sinais, sons, cheiros e rastros, as mulheres, não menos atentas, circundam as árvores que produzem frutos de que o jaboti gosta, cavoucam os buracos (iwiku) e vasculham com paus ou terçados os kuperin à procura de jabotis. Tudo em volta é observado na procura pelos jabotis, como as condições do tempo, se há paus caídos, folhas mexidas e frutos comidos ou mesmo os buracos no chão; por exemplo, quando o sol esquenta, jati (jaboti) vai comer bucha, um tipo de fruto. As crianças, quando acompanham seus pais, ficam atentas; avistam e apontam-lhes as árvores de cujos frutos os jabotis gostam, e os iwiku (buracos cavados na terra) e kuperin (galhos secos), locais de moradia dos jabotis. Nesse tipo de caçada, é costume levar parentes próximos, e não raro crianças e jovens são responsáveis por encontrar os jabotis. Depois de uma caminhada, param para o descanso. Nesse meio-tempo, encontram outros grupos de pessoas ou casais. Quando dispersam nas florestas, é comum andarem apenas com a família nuclear ou em casais; nesse caso, a intenção também é ficar em 
privacidade. Afinal, as andanças pelas matas são também propícias às relações sexuais. Em contraposição à interação frouxa entre os diferentes grupos domésticos na aldeia, na mata as famílias interagem de modo mais intenso e há uma maior abertura do casal (Viveiros de Castro 1986:272). A mata também é o local onde é efetuada a relação apihi-pihã. ${ }^{165}$ Assim, é na mata, a partir dos caminhos abertos pelos cônjuges e pelo apino, que se concretizam as relações sexuais em que o sêmen masculino "alimenta" e faz crescer o corpo feminino, além de produzir um novo corpo, feito que exige cópulas constantes a fim de engrossar o feto.

Após algum tempo caminhando à procura de jabotis, tanto na direção das árvores que produzem frutos de que eles gostam quanto nos kuperin e iwiku, chega o momento de iniciar o caminho de volta. O ponto de partida do grupo, em uma clareira, torna-se referência para o encontro, onde os casais exibem suas conquistas, entre jabotis, jacus, araras e tatus. Alguns casais chegam com os cabelos molhados, sinal de que tiveram momentos de intimidade. O êxito na caça não recai sobre todos os casais, e nesse caso uma nova tentativa será realizada no dia seguinte para satisfazer a vontade de Maï. Parte das presas apreendidas será consumida pelas famílias conjugais e/ou extensas, a depender da quantidade caçada. Essa situação permite que o jaboti, de comida dos deuses, passe a ser também comida dos homens, dinâmica que reafirma a fluidez das coisas e ações e explicita uma relação pouco cerimoniosa com os Maï. A pajelança do jaboti somente será feita quando todas as famílias da aldeia obtiverem a quantidade suficiente para oferecer jaboti cozido (i pipo), ${ }^{166}$ juntamente com o mingau de milho, aos Maï e aos mortos, a sua família extensa e às demais famílias de outras sessões residenciais. Os Araweté dizem que é preciso pegar muitos jabotis, porque há muitos Maï e eles gostam bastante de jaboti. O parente do morto que manifestou o desejo de comer jaboti avisa de casa em casa, quando o pajé for cantar, que chegou a hora de preparar os jabotis. $\mathrm{Na}$ noite anterior à pajelança, cada família nuclear prepara seu jaboti. O jaboti, antes de tudo, é lavado para tirar o barro. Depois quebram com terçado suas partes (jati ika, "quebrar, cortar") enquanto ainda está vivo. Separam as patas

\footnotetext{
${ }^{165}$ Nas matas, os casais trocados saem para caçar, tirar mel e catar jaboti, e à noite se reúnem para comer o que trouxeram. As expressões "levar para caçar", "levar para a mata" evocam a relação apihi-apino. O dia é com a apihi, à noite é com a esposa. Segundo Viveiros de Castro (1992:97), o jaboti e o mel são símbolos do período pós-casamento que envolve dois casais cuja relação é marcada pela alegria (tori).

${ }^{166}$ Viveiros de Castro (1986) elabora um sistema no qual podre/assado:cozido/cru:: $\tilde{A} \tilde{n} \underline{i}: M a \underline{i} \underline{\text {, em }}$ que Ani devora o cadáver do morto (isto é, a carne do morto, que, quando criança, é disposta embaixo de uma armação), e Maï, "as almas celestes cozidas [...]. O assado conota o modo de vida selvático dos $\tilde{A} \tilde{n} \underline{i}$ o cozido, o modo aldeão dos deuses" (Viveiros de Castro1986:487).
} 
dianteiras, a cabeça, as patas traseiras, o fígado e o coração. A parte de baixo do casco é colocada na fogueira para assar $(e-h i)$, pois dela é possível retirar alguns resquícios de carne que ficam aderidos ao casco e que são comidos no próprio dia do preparo. As demais partes do jaboti são de preferência cozidas, mas também podem ser assadas, para ser comidas no dia seguinte. Maï gosta de ovo e de fígado de jaboti, que são cozidos em panela separada. No canto, é possível comentar as características do cozido. Em uma das músicas cantadas pelo pajé, Maï dizia: "Não tem ovo de jaboti dentro. Tem pouco fígado de jaboti. Vamos comer logo jaboti, aí vamos nós. Vou agora para o Mai”. Disse-me Jarama hi que Maï vem pedir jaboti, mingau e beiju. Ao acordar, cada família coloca sua panela com jaboti cozido no pátio onde será realizada a cantoria, que pode ser na frente da casa tanto do cantador quanto do parente do morto. O pajé pintado de urucum, com penas de gavião na cabeça, balançando o chocalho aray e fumando seu charuto, permanece por algumas poucas horas cantando, com o auxílio de sua esposa, que também está pintada de urucum e tem a cabeça ornamentada com penas brancas, em volta das panelas. "A forma de comunicação dos deuses com o vivente é essencialmente o canto: é cantando (ou cantados) que eles descem à terra, é cantando que os xamãs os encontram no céu" (Viveiros de Castro 1986:232). Durante a cantoria dos pajés, ${ }^{167}$ as pessoas ficam ao redor do pátio conversando e tomando café. As famílias, em geral aquelas mais próximas do morto, oferecem ao Maï café, açúcar, fumo e terçado, produtos que serão recolhidos pelas próprias famílias que os ofertaram. Ao final, o pajé é conduzido pela esposa a sua casa, quando ainda canta por algum tempo antes de descansar. Após o benzimento das panelas com canto dos pajés e o consumo dos deuses, as famílias extensas se reúnem nos quintais para saborear os jabotis. Em uma das festas, uma panela foi retirada do centro do pátio antes do final da cantoria, e a explicação foi que Maï não podia comer aquele jati (jaboti), pois, segundo me explicaram, estava com "cartão vermelho", o que significava um impedimento, como em um jogo de futebol. Maï pediu para retirar as panelas, pois aquela comida faria mal a ele, mas não havia qualquer interdito ao consumo dos homens. Essa situação reforça a explicação, já mencionada, da carne de jaboti conter flechas que, se não estiverem bem apaziguadas, acabam fazendo mal aos Maï, mas não aos homens. Durante o dia, ou até acabar a carne, há uma intensa circulação de pessoas para consumir a comida da panela do outro. Cada família, em um dado momento, chama pelas demais a fim de

\footnotetext{
${ }^{167}$ Não é permitido tirar foto do pajé com flash quando ele está cantando, pois ele recebe uma espécie de choque e fica desmaiado por algum tempo.
} 
compartilhar a comida. "Cada casa convoca as outras, numa ronda alimentar onde o tenetãamõ deve ser, ao mesmo tempo, o que convida mais gente e é convidado - mas seus jabotis não são necessariamente os primeiros a serem comidos. Como sempre, os homens é que partilham e 'capturam' a carne, levando-a para junto das esposas" (Viveiros de Castro 1986:356). O pajé responsável pela cantoria, no entanto, não come a carne de jaboti preparada para a festa.

Cabe, assim, destacar a fundamental importância de considerarmos as relações céu/terra na dinâmica da caça e da circulação pelas matas. Se a camada celeste é o lugar dos Maï, ex-humanos que se transformaram em deuses, a mata é o lugar dos Ani, como indicado no capítulo I. A relação de alteridade funda-se em uma polaridade máxima que não é definida em termos substantivos, mas sim a partir das posições em jogo entre nós/sujeito (bide) e os outros (amite). Deve-se estar atento ao fato de que esta oposição não é clara e estável, mas relacional a partir da definição de um polo marcado, como seres humanos e Araweté. O limite dessa polaridade é a posição de inimigo, awi. As distinções entre os seres dependem dos contextos de contrastes e estão fundadas principalmente nas oposições entre seres criados e aqueles que simplesmente existem; entre aqueles que foram abandonados e aqueles que subiram ao céu (ou subirão); entre aquilo que se come e aqueles que nos comem; entre aqueles que são para matar e aqueles que nos matam. Seres e coisas não têm uma posição fixa e estão inseridos em uma dinâmica múltipla e serial, pois se trata de seres que são o mesmo e o outro, a depender da cadeia de relações que estão envolvidas na própria concretização das coisas.

As concepções relacionais em jogo colaboram intrínseca e dinamicamente para evidenciar descontinuidades nas matas que envolvem associações ecológicas, sociais, cosmológicas e a constante fabricação da pessoa. A presença de outrem é condição da atualização dos seres nos mundos. Relações de predação, aliança e afinidade (ou antiafinidade, como os apihi-piha) orientam a dinâmica do movimento e da criação de descontinuidades nas matas e os sentidos das interações entre seres e mundos. $\mathrm{O}$ devir dos mundos e seres ultrapassa relações fixas de oposição e instaura um constante tornarse outro. Uma caçada que envolve um banquete ritual evoca a dinâmica céu/terra e promove a conjunção entre os mortos e Maï, parentes e não parentes, jabotis e árvores. Há, portanto, um encadeamento de atos e sentidos que afetam e são afetados pelos 
sujeitos e seus outros, como uma conjunção de corpos em espaços-tempos estendidos e que, portanto, vão além da interação dos seres nos mundos.

\section{Andar nas florestas}

É corrente a afirmação de que as florestas são percebidas como um lugar perigoso (Garcia 2010; Cabral de Oliveira 2012). Perigoso para quem? Em quais circunstâncias? O perigo liga-se menos ao fato de se estar nas florestas do que aos cuidados e tratamentos dados aos corpos, à incorporação de saberes que proporcionem andar nas florestas em segurança, bem como aos tipos e à intensidade das relações que se efetuam entre os diferentes seres que afetem, de certa maneira, a circulação nesse domínio. As florestas, uma vez que são vividas de maneira polissêmica, podem ser lugares de prazer, de viver, caçar, coletar, comer, aprender, tecer, entre outras coisas, mas antes de mais nada são constituídas de trilhas e relações que envolvem diferentes seres. Assim, cabem as perguntas: florestas para quem? Em que contexto relacional?

Andar nas florestas, enquanto experiência imediata, requer e aciona mecanismos de constituição de corpos, de produção de relações, percepções, sistemas de significados e dinâmicas cosmológicas. Andar nas florestas envolve um emaranhado de relações sociais próximas ou distantes, imprevisíveis e perigosas, entre presas e predadores, donos, entre outras. Andar nas florestas configura-se também como modo de conhecer, pois é algo que constitui e é constituído por múltiplos conhecimentos.

Os Araweté costumam andar nas florestas principalmente para caçar. Além da caça, circulam pelas florestas para coletar frutos, madeira, palha, acessar a roça, dependendo de sua localização, um igarapé para pescar, estar entre casais, entre outras atividades.

Durante minha estadia entre os Araweté, acompanhei a construção de uma canoa e observei que ao menos duas famílias, algumas vezes na semana, passavam o dia em meio à mata, no local onde havia sido derrubada a árvore cujo tronco seria usado para a construção da canoa. Passávamos parte do dia no local da construção. Era verão, época sem chuvas e propícia a essa atividade. Ao menos dois barcos partiam para o local. Estavam sempre a esposa e filhas de Iwane ru, dois de seus irmãos, sendo um deles recém-casado e ativo na construção da canoa. Por vezes, apareciam outras famílias da 
aldeia. Da margem onde aportávamos, seguíamos um caminho na mata onde passávamos por um alagado (iriapa) até chegar no local de construção da canoa. Aos homens era reservada a tarefa de talhar e esculpir a madeira, base da construção da canoa; às mulheres, o cuidado com as crianças e o fogo, a observação do trabalho dos homens, a colaboração, quando convocadas, para atividades que envolviam força como ajudar a virar o tronco para ser serrado e esculpido em outra parte de sua superfície lateral - e para a tecelagem. As crianças, soltas e à vontade no entorno da canoa e das mulheres, observavam, brincavam e coletavam frutos para "petiscar". Após a canoa ser talhada e esculpida, ela seria arrastada até a margem do rio.

As atividades de caça, por vezes, seguem caminhos previamente traçados em decorrência das pistas das presas a serem abatidas, que nem sempre estão onde era esperado, como entre galhos secos, buracos cavados na terra, nas copas das árvores, na beira de igarapés, lagos, entre outros locais. A partir de intenções, ritmos e formatos conhecidos, mas com direito a improvisos pela constante redefinição dos trajetos traçados, andam e constituem florestas. Ou percorrem-se caminhos para a coleta de castanhas, açaí e bacaba, por exemplo.

Os aprendizados para andar nas florestas decorrem de processos de maturação. Nunca uma criança anda sozinha nas florestas. Sua autonomia é conquistada à medida que cresce e se encontra devidamente preparada. Aprender a andar nas florestas requer conviver, estar junto, enfim, acompanhar, de preferência, os pais nas incursões às florestas. Por vezes, andando descalça, com o tempo caleja os pés, fortalece o corpo e, paulatinamente, desenvolve a "atenção" para aprender a se resguardar de atividades perigosas e a cuidar de si. Desde bebês são carregadas pelas mães nas atividades que ocorrem em meio às florestas. Se for menino, acompanhará com mais frequência as atividades do pai, em especial as caçadas. Com o passar do tempo, saem para caçar, coletar madeira, entre outras atividades, em grupo da mesma faixa de idade, nas imediações da aldeia. Essa relativa independência dos pais ou de alguém mais velho para andar nas florestas sinaliza certa maturidade social. As tarefas assumidas, especialmente, dão indícios desse amadurecimento social. Quando pequenos acompanham os pais, mas sem expectativa de sucesso na caçada, por exemplo. Mais tarde, já estão aptos a colaborar nas caçadas, em especial nas de jabotis. E quando já estão preparados, por volta da época de seu casamento, os meninos ganham uma arma 
que se torna a expressão de sua maturidade.

A família conjugal participa de diversas atividades nas florestas, como caçadas coletivas, derrubadas de mata, coletas, entre outras. Nas caçadas coletivas, ora os Araweté estão apenas entre a própria família conjugal, ora em um grupo maior. Nesse caso, a caçada começa em grupo. Após um breve tempo de caminhada, as famílias se dispersam. A cada encontro de parte ou de todo o grupo, momentos de descanso, risadas e conversas, novos arranjos são compostos e novas trilhas desenhadas, dependendo do que foi caçado e das novas pistas que são apresentadas. A cada parada, a posição de presa/predador é redefinida, bem como a direção que deve ser seguida. Cheiros, rastros, sons, características do entorno e a disposição dos casais e das famílias, em geral, orientam a próxima jornada. Dispersam-se novamente, por caminhos já abertos ou por abrir, para após um período de busca da presa reencontrarem-se em novo ponto de parada. O êxito na caça não recai sobre todos.

A recorrência das incursões às florestas é determinante para o acúmulo de experiência e para desenvolver a atenção e os modos de perceber. Em paralelo, é fundamental constituir corpos e relações adequadas, além de alimentar-se apropriadamente. No processo de produção de corpos e pessoas, são incutidas capacidades que as tornam aptas a andar nas florestas, atividade previamente planejada, mas que conta com alto grau de improviso e imprevisto. Há sempre a possibilidade de deparar com inimigos, como Ani, entre outros, e deve-se estar atento a perigos iminentes, como ataques de onças e a presença de cobras ou de outros animais peçonhentos. Para andar nas florestas, devem-se seguir regras a fim de evitar aproximação excessiva com alguns seres. Em situações liminares, a atenção deve ser redobrada. Mas andar nas florestas também pode ser divertido e prazeroso, pois proporciona o estar junto e, sobretudo, garante o consumo de carne, muito apreciado entre os Araweté. 


\section{Capítulo IV - Modos ameríndios de constituir saberes}

Para abordar aspectos dos modos ameríndios de conhecer as florestas, é imprescindível tratar das formas de constituição de saberes, fundamentadas em procedimentos e lógicas que, embora sejam perceptualmente e localmente constituídos (Carneiro da Cunha 2009:301-302), não dependem apenas de estar presente nas florestas. Por outro lado, para andar nas florestas com segurança, atividade que nunca é fortuita, é preciso tê-las experimentado intensamente. Vale ressaltar que se saberes são constituídos localmente, devem ser sempre abordados no plural, no sentido de marcar sua multidimensionalidade e seu caráter dinâmico.

Se até aqui buscamos circunscrever florestas e redes de relações que as constituem, especialmente aquelas focadas nas cadeias associativas que envolvem vegetais, e as dimensões da socialidade no que se refere, principalmente, à fabricação de corpos e de pessoas, é porque, nos contextos ameríndios, ao menos, esses são aspectos imprescindíveis aos modos ameríndios de conhecer florestas.

Modos ameríndios de produzir, circular e expressar conhecimentos são inerentes a redes de relações sociocosmológicas e ecológicas ${ }^{168}$ - termo aplicado para expressar diversas formas de inter-relações entre os seres e as transformações decorrentes dessas conexões - que abarcam todos os âmbitos da vida. No entanto, para se ter "habilidade" para caminhar, se relacionar, perceber, caçar, etc. nos domínios das florestas é preciso intensa experimentação. "A intimidade com a floresta e seus habitantes, o interesse que se tem por eles, relacionam-se à percepção. É pela experiência direta que se aprende [...]" (Carneiro da Cunha 2009:366). Experimentar, por sua vez, não está descolado de sistemas de classificação, da operacionalização da lógica do sensível, da observação contínua, do uso da intuição e da inventividade, do processo de fabricação de corpos e da participação em cadeias relacionais. Assim, a exigência da organização e classificação de coisas e seres não prescinde da necessidade de experimentação recorrente (Lévi-Strauss 2005:24-29). Por sua vez, "[...] trata-se de reconhecer que as propriedades não são das coisas em si, nem estão nelas; são apenas diferenças, e só

\footnotetext{
${ }^{168}$ Davi Kopenawa define o termo ecologia da seguinte forma: "Na floresta, a ecologia somos nós, os humanos. Mas são também, tanto quanto nós, os xapiri, os animais, as árvores, os rios, os peixes, o céu, a chuva, o vento e o sol. É tudo o que veio à existência na floresta, longe dos brancos [...]" (Kopenawa \& Albert 2015:16).
} 
existem em relação. Por outro lado, reconhece-se também que a experiência perceptiva pode ser subjetiva, mas não os processos que a engendram. Nem o primado do objeto, nem do sujeito." (Bateson 2000 apud Velho 2001:136-137). Neste sentido, pode ser considerado profícuo recorrer, conforme destaca Otávio Velho, à noção de skill desenvolvida por Tim Ingold $(2000,2010,2012)$ que está relacionada à constituição de "habilidades", como veremos adiante. Considero, assim, que para abordar os modos ameríndios de conhecer é pertinente fazer algumas aproximações possíveis, respeitando, no entanto, as diferenças teóricas em jogo. Para saber fazer ou saber andar nas florestas sem se perder ou colocar a vida em risco, não basta desenvolver destreza física, tem que reconhecer e compartilhar uma ordem das coisas nos múltiplos planos relacionais. Estes são os alicerces intrínsecos à constituição de experiências e de "habilidades".

Se apenas corpos aptos e pessoas devidamente inseridas em redes de relações sociais têm condições de andar com segurança, se localizarem, terem sucesso na caça e coleta e viverem bem nas florestas, pretende-se nesse capítulo não apresentar apenas o que os Araweté afirmam conhecer sobre florestas e os seres que nela vivem, mas também explorar os aspectos que regem regimes de conhecimentos relacionados ao desenvolvimento de habilidades e capacidades fundamentais para circular, conviver e estar de maneira adequada nas florestas.

\section{Aprender fazendo}

Numa aldeia araweté - como em quase todas as aldeias amazônicas - as atividades são feitas em determinado momento e lugar, diante da participação na dinâmica da vida da família conjugal, da seção residencial e da aldeia. Aprende-se a tecer observando sua mãe ou outras mulheres e, em determinado momento, tecendo; aprende-se, no caso dos meninos, a preparar um terreno para fazer roça acompanhando os pais nas derrubadas, manuseando o facão, o machado e derrubando árvores; aprende-se a cozinhar estando junto ao fogo todos os dias e, aos poucos, cozinhando; aprende-se a caçar acompanhando o pai, andando nas matas, manuseando os artefatos de caça, caçando jabotis e, mais tarde, usando armas de fogo; aprende-se a pescar acompanhando a mãe lavando roupa e louça na beira do rio diariamente, nadando no rio, jogando anzol, colocando isca e pescando; e, assim por diante. Aprender a fazer algo requer, antes de tudo, estar junto, conviver, e significa muito mais do que realizar uma atividade 
exclusivamente dirigida a um resultado.

Nesse sentido, vale passar pela discussão proposta por Lévi-Strauss (2011) sobre as relações entre mito e rito, uma vez que está imbricada em um jogo constante entre um sistema que recorta o mundo por meio de oposições e contrastes e outro que parte de unidades discretas que lhes são impostas pela conceituação prévia do "real". O processo de aprendizagem não se limita a uma reação espontânea ao vivido. Aspectos afetivos e sensíveis não constituem um dado primeiro, exceto quando a situação vivida é de ordem estritamente fisiológica. A vida vivida não corresponde diretamente ao mundo nem às experiências no mundo, mas respondem ao modo como os homens pensam o mundo. Sistemas de significados se interpõem entre o mundo pensado e o vivido, o que indica que o pensamento não precede a apreensão do mundo, mas é marcado pela "[...] antinomia inerente à condição humana entre duas sujeições inelutáveis, a do viver e do pensar" (Lévi-Strauss 2011:657).

Aspectos sensíveis, portanto, fornecem substratos aos modos ameríndios de produção de conhecimentos. No entanto, os conhecimentos e práticas mobilizados no cotidiano não envolvem apenas a ordem do vivido, mas são a expressão dos modos como os mundos e as relações são apreendidas. "[...] as ciências humanas têm de se convencer de que a realidade de seu objeto de estudo não se encontra inteiramente aquartelada no nível em que o sujeito a percebe. Essas aparências recobrem outras aparências que não valem mais do que as primeiras, e assim por diante, até uma natureza última que sempre se esquiva e que certamente não atingiremos jamais. Tais níveis de aparência não se excluem nem contradizem uns aos outros, e a escolha que se faz de um deles ou de vários liga-se às questões que se coloca e às várias propriedades que se quer apreender ou interpretar" (Lévi-Strauss 2011:615).

Por outro lado, Ingold (2000, 2010) pautado em uma abordagem fenomenológica, defende que a faculdade humana de conhecer baseia-se não em alguma combinação de capacidades inatas e competências adquiridas, mas em habilidades criadas nas relações. Essa proposta é vantajosa para explorarmos o desenvolvimento de habilidades centradas, em grande medida, nos corpos. Os humanos seriam, nessa perspectiva, centros de percepções e de agência em um campo da prática. Ingold defende que os conhecimentos não são adquiridos por meio de estruturas pré-existentes, mas brotam 
nos processos de interação entre organismos e ambientes, na interação da vida da pessoa no mundo. O desenvolvimento das capacidades não está dentro do corpo e do cérebro, nem no ambiente, mas depende da interação com o ambiente. $\mathrm{O}$ aprendizado vincula-se a uma percepção orientada e ocorre pela participação ativa e criativa dos organismospessoa em contextos de interação. Nesse sentido, vale mais uma vez reforçar que se interações de diversas ordens são necessárias ao processo de aprendizagem em sociedades orais, não podemos deixar de destacar que se tratam de interações posicionadas a partir de códigos compartilhados. Ainda assim, a abordagem defendida por Tim Ingold é muito valiosa tanto por privilegiar os contextos de interações, como pela noção de skill. Tim Ingold (2010) reconhece o papel da experiência e da transmissão geracional de conhecimentos, mas destaca, sobretudo, a premência de uma "educação da atenção".

A pessoa não seria reflexo de um sistema de representações instituídas socialmente, pois não se trata de ter a pessoa de um lado e sociedades ou mundos de outro, como apontamos no capítulo III, mas de suas posições como focos de agenciamentos em campos relacionais $^{169}$ que, por sua vez, estariam vinculados a categorias lógicas que não são constituídas a priori, como defende Lévi-Strauss (2011). Aprender fazendo, nesse sentido, não está descolado dos contextos relacionais e da dinâmica da vida social.

Mas, como entender as práticas sociais? As atividades práticas não se configuram como repetição de ações cotidianas com fins apenas utilitários, mas se ligam intrinsecamente a dimensões da socialidade e aos modos como as coisas são feitas e concebidas. Nesse sentido, as práticas sociais estão relacionadas aos sistemas de significados, às percepções e experimentações atreladas à lógica do sensível e aos contextos relacionais. Descola (2013), ao refletir sobre a prática social inspirado por sua orientação estruturalista, questiona se esquemas interacionais seriam fruto da contingência e da

\footnotetext{
${ }^{169}$ Para tratar da noção de habilidade, Ingold (2010) usa como exemplo os movimentos de um lenhador que derruba uma árvore com um machado. O movimento do machado não decorreria apenas de um movimento mecânico de um comando mental, mas de um sistema de relações que envolve machado, homem e árvore, ou seja, o desempenho do lenhador estaria relacionado ao engajamento organismo/ambiente (2010:17-18). Não se trata de capacidades inatas e competências adquiridas, mas daquilo que Ingold denomina como habilidade, faculdade relacionada à capacidade de percepção e resposta ao ambiente, isto é, ao entorno, ajustada às experiências anteriores e que, por sua vez, seria a base do conhecimento. "O conhecer, então, não reside nas relações entre estruturas no mundo e estruturas na mente, mas é imanente à vida e consciência do conhecedor, pois desabrocha dentro do campo de prática - a taskscape - estabelecido através de sua presença enquanto ser-no-mundo" (Ingold 2010:21).
} 
repetição e conclui que "[...] o que é central é esse sujeito que conhece, que interage com seu meio ambiente, e que, devido ao que percebe e ativa nele, se inscreverá no interior de um desses esquemas de identificação e o estabilizará. É dessa maneira que vejo agora a prática social, de uma maneira mais estrutural" (2013:503).

$\mathrm{Na}$ aldeia Djuruanti, em outubro de 2012 - final do período da seca -, as famílias araweté se organizaram para preparar uma área para o plantio de uma roça de milho. $\mathrm{O}$ dia e o momento de sair da aldeia em direção à área a ser derrubada eram indicados pelo tenetãmõ que, quando o solo estivesse preparado, assumiria a condição de "dono" daquela roça. A maioria das famílias conjugais, principalmente os parentes próximos e os vizinhos da mesma seção residencial do tenetãmõ se organizou para passar o dia na derrubada. "A abertura de um roçado consiste em três fases: a broca, a derrubada e a queima, todas realizadas exclusivamente por homens. Para a broca é utilizado o facão e para a derrubada, o machado e, quando disponível, a motosserra" (Faria 2007:143). Essa era uma área de mata alta, um pouco distante da aldeia. Ao chegarem no local, as famílias desbastavam e tratavam de tirar galhos, folhas e pequenos animais, por vezes peçonhentos, do local onde iriam armar suas redes e acender o fogo. As mulheres ficavam nas redes, conversavam, cozinhavam, teciam as saias, cuidavam das crianças e buscavam água em cacimbas abertas nas imediações. As crianças brincavam e circulavam por tudo. Tenetãmo ofereceu café e arroz para todos. Alguns homens derrubavam com motosserra as árvores mais grossas e duras, e os demais usavam machados. Meninos em grupo desbastavam a área com facão e, no caso de serem mais velhos usavam o machado para derrubar as árvores menores e mais finas. No fim do dia, restavam apenas as árvores menores, próximas das redes, para os mais jovens derrubarem. Três meninos tentavam com machados abrir um talo no tronco de uma árvore. Um duro esforço era empreendido. Nesse momento, alguns homens adultos, após um dia intenso de trabalho, deitaram-se nas redes e observavam os meninos naquele movimento cadente dos machados que, aos poucos, feriam o tronco da árvore. Quando o talo foi ganhando profundidade, um dos homens, em especial, começou a orientar a direção e os movimentos que deveriam fazer no intuito de direcionar a queda do tronco. Aos poucos e diante de fortes estrondos das quedas das árvores, a clareira tomava forma. Por que as coisas foram organizadas dessa forma? Por que homens e meninos assumiram a derrubada das árvores de modo diverso? Essa situação, como parece ter ficado demonstrada, é operacionalizada tanto a partir de lógicas sensíveis 
quanto de sistemas de classificação, que, por sua vez, indicam modos de agir diversos ao se comparar as atividades dos homens com a dos meninos, no que se refere, por exemplo, aos tipos de madeira derrubada por cada qual.

Ao perguntar a Majato como aprendeu a tecer saias, assim ela me respondeu: "a gente aprende". Mulheres ou meninas tecendo suas saias é uma cena frequente entre os Araweté, seja na aldeia, nas matas, ou em qualquer lugar onde possam fincar dois talos de babaçu no chão, que são usados como suporte para tecerem a saia com algodão vermelho. Elas passam às vezes horas tecendo, sempre com as crianças em volta. As meninas na faixa dos dez anos começam a tecer sua própria saia em um suporte armado especialmente para elas: aprendem a tecer observando as outras mulheres, convivendo com essa atividade diariamente, enrolando o fio no talo, tecendo um pouco a saia de outras mulheres e, por fim, tecendo a sua própria saia. Vez ou outra recebem alguma orientação de sua mãe, avó ou de alguma mulher que esteja de passagem. O aprendizado ocorre aos poucos e é aprimorado à medida que corpo e prática vão se constituindo mutuamente. E mais, por que tecer aquela saia daquele jeito? Por que usar aquela saia? Portanto, a técnica e o artefato produzido não se dissociam das relações que os envolvem e de seus respectivos significados.

Hawutire, certa vez, disse-me que poderia andar em qualquer mata que conseguiria se localizar. Possuir um corpo maduro, que passou por processos de fabricação e vivências nas matas, "saber perceber" os sinais em seu entorno e os seres perigosos, definir elementos norteadores como rios e caminhos são aspectos relevantes nessa empreitada. Assim, "[...] o descobrir-caminho é entendido como desempenho habilidoso pelo qual o viajante, cujos poderes de percepção e de ação foram afinados através de experiências anteriores, 'sente seu caminho' rumo a seu objetivo, ajustando continuamente seus movimentos em resposta ao monitoramento perceptivo contínuo do seu entorno" (Ingold 214:77).

"[...] no contexto wajãpi, a experiência é engendrada e alicerçada justamente por um conjunto de percepções fiáveis apreendidas em todas as suas medidas pelos sentidos. É por meio dos cheiros, sabores, sons, luzes e texturas que as experiências mais diversas se constituem, são colecionadas e podem ser transmitidas" (Cabral de Oliveira 2012:226). O aprendizado decorre, em grande medida, de elementos perceptuais, mas 
dinâmicas sociocosmológicas, entre outras dimensões da socialidade como já indicado, também são fundamentais nesse processo. Entre os Pirahã, "[...] ensinar reside no mostrar ou no falar, enquanto o aprender e o saber estão relacionados ao olhar" (Gonçalves 2001:184). Para eles, os heróis civilizadores têm grande contribuição no processo de aprendizado. Os abaisi ${ }^{170}$ detêm o conhecimento sobre tudo e sabem fazer bem as coisas. "Os ibiisi não sabem cantar, não sabem fazer casa, não sabem fazer roça, não sabem fazer adornos de palha, não sabem dançar. Mesmo não sabendo fazer as coisas, não deixam de tentar fazê-las; 'experimentam' a todo momento, numa tentativa de imitar os feitos de abaisi. Tudo que os ibiisi fazem, embora seja 'mal feito', foi aprendido com os abaisi (op.cit.:184). Nesses exemplos as experiências são constituídas tanto a partir das qualidades sensíveis quanto das relações estabelecidas em diversos planos. Não se trata, portanto, de uma forma de aprendizado apenas intergeracional e linear, como podemos observar entre os Yudjá na caça de porcos. Neste caso, Lima (1996:39) indica que as experiências são duplas, sendo experiência sensível e também da alma, ambas, como efeitos de perspectivas. Assim, perspectivas diferentes engendram experiências que se complementam.

A convivência, os significados compartilhados, a atenção ao entorno, qualidades sensíveis, como sons, cheiros, características táteis e formas, por exemplo, e a contínua incorporação de habilidades compõem, portanto, uma base dos aprendizados nessas sociedades indígenas.

\section{Brincando é que se aprende}

Brincar é divertimento, aprendizado, constituição de percepções e relações, abertura à experimentação, muitas vezes através da imitação e sem compromisso com a obtenção de resultados. Brincar envolve emoções, criatividade e experimentações. No contexto ameríndio, brincar não tem espaço específico ou hora marcada, como ocorre muitas vezes com crianças em locais onde as brincadeiras são dirigidas. Brincar, naqueles contextos, não é tratado como algo instrumental voltado ao desenvolvimento da criança, mas como parte da vida, da convivência, das interações e da constituição da pessoa.

\footnotetext{
${ }^{170}$ Como indicado no capítulo II, abaisi, seres que povoam diversos patamares do cosmos, tendo, entre eles o Igagai que é o responsável pela criação das coisas que existem no patamar pirahã, e são e ibiisi, designação genérica para "seres humanos", são os Pirahã, outros povos indígenas e não indígenas (Gonçalves 2001:178, 225).
} 
Os brinquedos, ou melhor, os artefatos usados nas brincadeiras são as coisas disponíveis, como pedaços de pau, pedras, terçados, frutas, canoas, armadilhas, aviões feitos de paus, pequenos arcos e flechas esculpidos por um adulto, enfim, qualquer objeto que esteja a disposição, ou, como em muitas situações, o próprio corpo. Nesse contexto, o brinquedo não foi produzido para a criança - como no mercado de brinquedos - e tampouco oferecido pelos pais, como ocorre entre os não índios, mas é elaborado ou confeccionado, muitas vezes, pelas próprias crianças. Para as crianças, todos os lugares são suscetíveis a brincadeiras, as quais acontecem no rio, no entorno das casas, nas matas, nas roças ou em qualquer outro lugar onde remar canoa, montar armadilha para prender pássaros, cantar as músicas de Maï, subir em árvores, lançar flechas, entre outras coisas, faça parte de seu dia a dia.

As brincadeiras inserem-se em contextos horizontais de aprendizagem, por mais que sejam conduzidas por alguém, e revelam o engajamento das crianças na vivência de seus sistemas sociais não apenas como imitação do mundo adulto, mas também como aprendizado " [...] sobre seu próprio mundo, a partir de um compartilhamento de saberes entre seus pares, o que se dá geralmente através das atividades lúdicas" (Codonho 2009:144). Nesse sentido, Benjamin (1987:252), ao abordar a brincadeira em "sociedades ocidentais", destaca o condicionamento do brinquedo ao sistema econômico e ao que considera um erro, que seria perceber "[...] a brincadeira excessivamente da perspectiva do adulto, do ponto de vista da imitação".

Durante acampamento com os Araweté em meio à floresta para caçar jabotis, cuidei de dois meninos enquanto seus pais partiram para a caçada. O mais velho, Karapi, ficou grande parte do tempo com um terçado quebrando pau, coco babaçu, esculpindo uma flecha pequena, desfazendo ninho de formiga tucandeira (tukani) e afiando o facão. Seu irmão mais novo, Narapi, seguia e imitava Karapi, só que ao invés de terçado, portava um pequeno pau. Karapi também incumbiu-se de acender a fogueira e cuidar do irmão menor. Além disso, a todo o momento trepavam nos esteios que serviam de suporte às redes. Nessa circunstância, "o próprio corpo transforma-se em brincadeira à qual a imaginação não dá descanso, recriando a essência dos mesmos gestos em inúmeras formas e possibilidades (Nunes 2002:87). 
Em outro contexto etnográfico, há o relato de meninas Kayapó-Xikrin brincando com bonecas que são produzidas pela transformação de "[...] abóboras, olhos de cacho de banana ou qualquer outro objeto em bebês, ou os modelando em argila, e os pintando cuidadosamente com motivos de pintura corporal característicos de bebês de colo, ou ainda para se pintar umas às outras, como na reunião coletiva de pintura das mulheres. Aqui também, no entanto, não devemos entender sua atividade como mera imitação do que os adultos fazem. Assim, se elas se pintam umas às outras, o fazem com carvão (e não com jenipapo, que marca o corpo por dias, e que [...] deve ser realizado de modo apropriado; o carvão, por sua vez, é facilmente lavável), e com uma maior liberdade de combinação de motivos do que têm as mulheres" (Cohn 2000a:205). Crianças guarani mbya costumam "imitar" os rezadores, seja por incentivo dos adultos ou em brincadeiras cotidianas. Adriana Testa (2014:262) relata ter visto crianças pequenas, "[...] geralmente em trios, escolherem alguém para ser rezador(a), uma outra criança para ser a mãe de uma criança adoecida (uma boneca) e um ou mais xondaro/xondarea (auxiliares masculinos/femininos de quem estava fazendo a cura). Nestas ocasiões, a mãe da boneca procurava o/a xamã, que pegava um cachimbo apagado e começava a dar voltas no amba (suporte ritual que se localiza na frente das casas de reza), acompanhado por seus xondaro. A mãe então sentava num banco de frente para o amba, com a boneca despida no seu colo. Depois que o/a xamã e seus xondaro tinham terminado de tratar a boneca, a mãe colocava as roupas novamente na boneca e se levantava”. Na aldeia araweté Djuruanti, uma tarde, enquanto um pai, sentado no pátio, fazia ajustes em seu arco e flecha em frente a sua casa, atividade realizada em especial por homens mais velhos, seu filho pequeno, de no máximo quatro anos, insistia repetidamente em lançar uma rede de pesca. O movimento de seu corpo era determinante para o ângulo dado à rede, que caía na terra, sem um alvo específico.

As brincadeiras, em grande parte entremeadas às atividades cotidianas, mesmo quando têm como referência os "mundos" dos adultos, irmãos mais velhos ou rezadores, não devem ser entendidas como mera imitação. Além da diversão e da distração que proporcionam, enfim, de seu caráter lúdico, as crianças, nas brincadeiras, efetuam “[...] uma constituição ativa de relações sociais que as acompanharão por toda a vida" (Cohn 2000a:211) e, assim, incorporam intensos aprendizados. As crianças em suas brincadeiras são, portanto, agentes que constroem relações e vivenciam experiências, e 
não devem ser percebidas como "[...] um sujeito incompleto, ou um adulto em miniatura que treina a vida adulta" (op.cit.:96).

A brincadeira é regida pela repetição, o fazer de novo a mesma coisa, seja no mesmo lugar, com as mesmas pessoas, ou em outro lugar, com outras pessoas, o que não significa, por sua vez, uma reprodução do mesmo. A repetição caminha junto com o improviso; pessoas, objetos e situações - se há a presença de árvores e rios, por exemplo - disponíveis nem sempre são os mesmos, e é a partir deles que são feitas as brincadeiras. "A criança recria essa experiência, começa sempre tudo de novo, desde o início [...] é a transformação em hábito de uma experiência devastadora. Pois é a brincadeira, e nada mais, que está na origem de todos os hábitos" (Benjamin 1987:253). A repetição engendra a renovação, pois a participação ganha novos contornos, possibilidades e desafios. "A insistência na repetição cria, portanto, oportunidades para melhorar a performance, permite a tranquilidade de sair de uma base segura e ser audacioso, abre caminho para a invenção" (Nunes 2002:83). Como apresentado nos capítulos anteriores, diversos são os elementos que contribuem com a constituição de modos de fazer, viver e se relacionar. Nesse processo, no entanto, não podemos deixar de considerar a brincadeira como uma instância importante na fabricação de corpos, na constituição de relações e, por sua vez, de vivências de diversas situações em diferentes lugares.

As crianças, como observei entre os Araweté e como comentam outros etnógrafos, estão sempre com seus pais, parentes próximos ou entre as próprias crianças em todos os momentos do dia a dia. Se por um lado as crianças têm uma mobilidade maior para circular pela aldeia (Cohn 2000a:205; Nunes 2002:72) e desfrutam de um convívio familiar intenso, por outro formam grupos de convivência definidos, como entre os Galibi-Marworno, onde "[...] as crianças realizam todas as suas atividades cotidianas na companhia de seus irmãos reais e classificatórios, evitando o contato com as crianças das outras famílias não aparentadas" (Codonho 2009:152), inclusive para afastar-se de eventuais brigas, pois estão também todo o tempo se provocando e zombando umas das outras. Entre os Araweté percebi uma dinâmica similar, pois ao ser convidada para comer ou circular em determinada casa ou seção residencial, se estava em companhia de alguma criança ligada a outro grupo de parente, era, de certa forma e de modo bem sutil, abandonada. Se me acompanhassem em alguma casa que não fosse de um parente 
próximo durante uma refeição, por exemplo, ou comiam do meu prato porque eu oferecia, ou simplesmente não comiam.

Aos poucos, as crianças assumem pequenas tarefas, que variam de acordo com o gênero e o grupo de idade, como carregar cestos, lavar louça e roupa, descascar mandioca, remar, cuidar de crianças menores, arremessar a linha para pegar peixe, limpar peixe, acender fogo e preparar a comida. Quando os pais vão caçar e não levam os filhos, as crianças mais velhas ficam encarregadas de cuidar das crianças menores, situação recorrente em outros contextos etnográficos (Cohn 2000a:204; Codonho 2009:145). Esse momento ocorre sob os olhares de pessoas mais velhas, mães de filhos pequenos ou grávidas que porventura ficaram na aldeia. A turma de crianças anda para lá e para cá, ora cozinhando, ora comendo, correndo, lavando louça, remando a canoa, e assim passa o dia. Participar ou assumir tarefas domésticas e atividades produtivas não impede a diversão, ao contrário, pois essas atividades são entremeadas pela brincadeira em seu caráter lúdico (Nunes 2002:74). Em um relato sobre as crianças Galibi-Marworno é notada “[...] a satisfação das meninas, que, entre um esfregão e outro das roupas que lavavam no rio, pulavam na água e brincavam das mais variadas formas: competiam no nado, pulavam da ponte, dos barcos e canoas lá ancorados, imitavam jacaré, passavam por debaixo das pernas das outras crianças formando túneis subaquáticos, entre outras invenções! No entanto, isto não impedia que chegassem em casa com as roupas lavadas e o dever cumprido" (Codonho 2009:145). Certo dia, algumas crianças araweté foram pegar um tipo de peixe denominado zizu em um lago. Estavam em companhia de um adulto, responsável por conduzir o barco, e eram entre dez crianças e jovens. Precisavam mergulhar na água para capturar esse peixe. As crianças, então, pulavam na água, nadavam, divertiam-se demais e, entre picada de marimbondo, choque de poraquê - duas crianças levaram descargas elétricas desse peixe e choraram, mas não foram choques de alta voltagem -, pegavam diversos peixes. Depois de saírem do lago, arrumaram um amontoado de paus e acenderam a fogueira para assar parte dos peixes ali mesmo. Nesse meio-tempo, subiam em árvores, tiravam espinhos do corpo e cuidavam dos peixes. Na volta, paramos em uma ilha no rio Xingu, onde nadaram, apostaram corrida e brincaram na areia. Ao chegar na aldeia, limparam o restante dos peixes e entregaram a seus pais. Nas matas, sob sol ou chuva, as crianças seguem os pais e, nas paradas, sobem em árvores, coletam e comem frutos, descascam e comem larvas de coco babaçu, quando há, e ficam atentas a todos os sinais, como ronco de 
queixada, esconderijos de jabotis, frutos comidos pelos animais, locais para coleta de castanhas, pois desde recém-nascidas acompanham os pais nessas incursões.

As experiências, portanto, não são compartimentalizadas e as crianças brincam, executam suas obrigações, divertem-se, aprendem e ensinam, tudo ao mesmo tempo. " $\mathrm{E}$ é assim, em meio a brincadeiras e obrigações, sem que estas sejam estanquemente separadas, que se dá o cotidiano das crianças Galibi-Marworno. Estas atividades, no entanto, não são realizadas solitariamente, já que sempre se encontram na companhia de outras crianças, com quem passam a maior parte do tempo" (Codonho 2009:148).

As crianças exploram "as coisas" nos mundos, testam e desafiam a si mesmas, aos outros, à topografia, caçam e decepam pequenos animais, exploram seu entorno, contam histórias, cantam, sabem e ensinam sobre os animais, as árvores, as épocas que produzem frutos, as coisas da roça, enfim, conhecem "[...] o mundo a seu redor pelos seus próprios olhos, testes e hipóteses experimentais, o que muitas vezes ocorre sem a presença de adultos" (Codonho 2007:99).

No convívio diário, as crianças compartilham, trocam, descobrem, criam e recriam experiências e conhecimentos, e as brincadeiras, em meio a outras atividades e pautando-se em repertório dos adultos, na própria dinâmica da vida, nas atividades cotidianas, na curiosidade e na criatividade, divertem e produzem corpos, pessoas e relações.

\section{Imitar e inventar}

Como nas brincadeiras, os aprendizados relativos às atividades do dia a dia ocorrem, em grande medida, pela observação ativa, a repetição e a imitação a partir de vivências cotidianas. Usar um terçado, lançar uma rede de pesca, tecer, remar, subir no pé de açaí, cozinhar, nadar, cantar, fumar para se fazer pajé, acender fogo, além do modo de sentar, andar, entre outras, são habilidades onde a repetição e a imitação são pilares de seu desenvolvimento, mas que, por sua vez, não estão descoladas do contexto social. Repetir e imitar, nesses casos, não são meras ações mecânicas e reproduções voltadas ao aprimoramento de gestos e ações, mas aspectos intrínsecos ao viver e se relacionar que se configuram como elementos fundamentais na constituição de saberes. 
Uma criança araweté, quando pega um terçado e bate em tudo o que vê pela frente, corta lascas de pau caído, martela qualquer tora, desfaz ninhos de formigas, descasca árvores, limpa matos quando segue o pai em um caminho, corta pequenos gravetos ou mesmo troncos, repete e imita, de certa forma, os pais. Por outro lado, está fazendo outra atividade, muitas vezes com propósito diverso, a partir do próprio corpo, em outro tempo e lugar. Não são, enfim, atividades ou ações realizadas a partir de uma relação formal e consciente de ensino-aprendizagem, e tampouco idênticas àquelas que serviram de referencial. No entanto, em todas essas atividades o terçado está presente e seu uso repetido é fundamental para o desenvolvimento de sua habilidade e, além disso, para o estabelecimento de relação com as coisas que estão em seu entorno.

Yano (2010:98-99), por sua vez, relata uma situação onde um jovem caxinauá se queixa de não conseguir aprender cantos caxinauá pela repetição e a memorização a partir de um caderno de pesquisa. ${ }^{171}$ A despeito da necessidade de repetição, essa situação reforça o entendimento de que o aprendizado não decorre apenas de ações técnicas, como a própria repetição, por exemplo, mas para ser efetivo deve estar imbuído de significado, o que ocorre de forma plena apenas contextualmente. A incorporação de saberes tampouco decorre simplesmente do acúmulo de experiências que " [...] depende, contudo, para sua boa absorção, da maturidade corporal-intelectual da pessoa ao mesmo tempo que se inscreve em seu corpo e o modifica, concorrendo, por seu turno, para aquele amadurecimento [...] Nesse sentido, o corpo caxinauá não é mero repositório passivo de conhecimentos diversos; a prática dos saberes, aqui, requer e promove corporalidades específicas" (Yano 2009:96).

Imitar não é um processo de cópia, mas de (re)descobrimento, que envolve um misto de repetição incansável, reprodução e improvisação. Imitar é improvisar na medida em que o contexto, as relações e o momento não são os mesmos e, nesse processo, estão sendo estabelecidas interações entre diferentes seres e coisas; não se repete de forma idêntica gestos, palavras e situações, o que, por si só, já promove novas experiências e relações.

\footnotetext{
${ }^{171}$ Esse Caderno de Pesquisa havia sido elaborado pela Comissão Pró-Índio do Acre para servir de subsídio aos professores indígenas que atuam nas escolas indígenas (Yano 2010:98).
} 
No entanto, a imitação desmedida, no contexto ameríndio, pode gerar a transformação em outro, como alerta Oliveira (2012:186) a partir de um relato wajãpi, quando, em tempos passados, "dois irmãos que, ao brincarem (ojimarai) de macaco-aranha, enegreceram seus corpos com jenipapo e avermelharam seus rostos com urucum; subiram, então, em uma árvore e, imitando (owa'ã) os gritos e movimentos do primata, transformaram-se em macaco-aranha, sumindo mata adentro", por exemplo.

A imitação ocorre, portanto, como um exercício de atenção, percepção, experimentação, inclusive de relações, produção de corpos e pessoas e, também, invenção, noção que será enfatizada a seguir. Nesse sentido, vale entender como foi abordado o que foi denominado modo de criatividade de habitantes de Costa Rai, na Papua-Nova Guiné. A criatividade, conforme foi relatada nesse contexto, baseia-se na geração de pessoas por meio de combinações intencionais calcadas em ações de pessoas e seres sobre outros agentes, que por sua vez geram pessoas ou coisas portadoras de agência e, portanto, dotadas de capacidade criativa (Leach 2004 apud Galan de Paula 2011). Não se trata de um modo de criatividade ativado pelo intelecto, focado nas pessoas e expresso em objetos materiais, muitas vezes considerados como não sendo dotados de intencionalidade. Na Melanésia, “[...] o que é criado por meio das combinações são pessoas capazes de criar outras pessoas, com base em combinações futuras" (Galan 2011:13).

O potencial criativo estaria, também, na própria abertura para o outro, como observado entre os Djeoromitxi, falantes de língua macro-jê. Esse povo passou por intenso histórico de contato e, diante dessa situação, “dizem, como exemplo, que quase ninguém, e somente os mais velhos da aldeia, sabem fazer a rede de algodão, os potes de cerâmica, os bancos dos pajés. Nenhum dos jovens, e essa é uma imagem recorrente, sabe adequadamente realizar aquilo que os mais velhos realizam" (Soares-Pinto 2014:267). Essa é uma fala recorrente entre alguns povos indígenas, especialmente aqueles que estão em contato intenso com os não índios, ou que viveram uma mudança forçada de território, por exemplo. Por outro lado, naquele caso, houve uma recusa dos mais velhos em ensinar, conduta atribuída à falta de interesse dos jovens em se submeter aos processos de aprendizagem, em especial, como o processo de fazer pajés, que requeria momentos de privações e sofrimentos (op.cit.:269). Situação essa não observada entre os Araweté. $\mathrm{Na}$ aldeia Ta'akati, ao longo de três anos, 
consecutivamente, foram formados três pajés. Nesse caso, a formação ocorre pela ingestão de muito tabaco, como apresentado anteriormente, e por meio dos sonhos, momento em que entram em contato com Maï. A formação de pajés araweté depende, portanto, da incorporação de saberes e do estabelecimento de relações no plano onírico. Bom, voltando à formação de pajés entre os Djeoromitxi, a qual pode acontecer de formas variadas, mas de alguma maneira depende de os pajés mais velhos acompanharem os neófitos em sessões de rapé nas matas e de severas restrições alimentares durante esse período. A completa formação ocorre pela colocação de taboquinhas por um pajé abaixo da garganta do neófito, as quais pertencem principalmente a pajés já falecidos. Esses são os instrumentos de cura dos pajés, que, por sua vez, estão visíveis apenas para eles. Diante dessa situação, os jovens reclamavam que os velhos não querem repassar as "armas" dos pajés; já os mais velhos diziam que os jovens não queriam passar pelo processo de formação, dinâmica que segundo Soares-Pinto (2014) é constituinte do processo de formação de pajés. Além disso, essa formação se completa por meio de experiências oníricas, quando estão em contato com espíritos donos de vegetais, animais etc. e vivenciam adoecimentos que provocam encontros, o que chamam de "descobertas", as quais não necessitam da participação de pajés mais velhos. Essa situação, de acordo com Soares-Pinto (2014:274-75), revela que "perdas-descobertas" tornam-se propulsoras do potencial criativo à medida que são inerentes à própria abertura para o outro. Assim, fica evidenciado que as "descobertas" também dependem da predisposição de abertura para o outro.

Outro aspecto fundamental atrelado ao processo de descobertas entre os ameríndios está relacionado à "ciência do concreto", destacada, sobretudo, com relação ao vasto conhecimento que possuem sobre vegetais e animais, por exemplo, cujo "objeto primeiro não é de ordem prática", como há muito tempo foi percebido e demonstrado por Lévi-Strauss (2005:24). Como uma planta silvestre foi domesticada, por exemplo? Esse tipo de descoberta, entre outras, como a produção de cerâmica, a domesticação de animais, “[...] supõe séculos de observação ativa e metódica, hipóteses ousadas e controladas, a fim de rejeitá-las ou confirmá-las através de experiências incansavelmente repetidas" (op.cit.:29). Os resultados, assim, decorrem dos elementos disponíveis, cujos sentidos e significados somente se completam à medida que são organizados em conjuntos estruturados que podem, inclusive, ser constantemente 
reorganizados (op.cit.:32-37), o que colabora para conferir a esse modo de produção de conhecimentos um alto grau de imprevisibilidade.

Assim, um Wajãpi conta que "inventa" um remédio ao ser picado por aranha e, sem saber como tratar a picada, resolve aplicar a casca de uma árvore cheirosa, cujo efeito foi o estancamento da dor e do processo inflamatório. Segundo Oliveira (2012:187), os aromas agradáveis são associados pelos Wajãpi a proteção e bem-estar, e esse foi o princípio aplicado na tentativa de reverter os efeitos da picada de aranha. Quando eu estava na mata com os Araweté, fui picada por um escorpião, e a indicação foi jogar gasolina na minha mão. A gasolina era usada como combustível para uma motosserra durante a fabricação de uma canoa. Naquele momento, fiquei um pouco desconfiada, mas todos fizeram essa recomendação com tanta segurança, que não tive outra alternativa; fora que, por estar longe da aldeia e por eles não terem indicado outra coisa, tinha que seguir aquela orientação. Se casca de árvore ou gasolina, o fato é que constantemente incorporam e testam novos saberes a partir de lógicas preexistentes, mas que nem sempre resultam na eficácia esperada (Oliveira 2010:187). Nesse sentido, vale emprestar a noção de invenção de Roy Wagner (2010a:18), em que ela é entendida como um processo de "obviação" pautado no contraste entre os símbolos e as coisas que simbolizam, dinâmica que gera mudança, seja pela absorção, seja pela derivação para outros modos. É como uma metamorfose contínua de algo preexistente, e não o desenvolvimento do novo a partir de uma matéria inerte ou de uma descoberta acidental. E, como um espelho da vida cotidiana, o que está em questão é justamente a improvisação inerente ao próprio viver, onde os códigos e os "“[...] controles são temas para interpretação e variação" (Wagner 2010a:145), mas sem perder a conexão com as convenções. A invenção seria então "[...] um componente positivo e esperado da vida humana" (op.cit.:19).

As condições nas quais está baseada a produção de conhecimentos entre os ameríndios envolvem, portanto, processos de invenção e transformação permanentes calcados, sobretudo, em sistemas de significados e na própria dinâmica da vida. 


\section{Pensar, sonhar e contar}

Pensar, sonhar e contar são formas de ação e de criar relações que constituem corpos e modos de conhecer. Para os Araweté a noção $\mathrm{kaaki}^{172}$ significa “[...] pensar, lembrar, saber, meditar, manifestar a presença de uma consciência. [...]. Enquanto ligada ao peito, ela se associa à noção de $i$, alma/princípio vital, cuja presença dentro do corpo marca o estado normal da pessoa: saúde e vigília. Sua ligação aos ouvidos se evidencia de modo negativo pela expressão apihã-i, 'surdo', com que se designa aqueles que procedem erradamente, não 'ouvindo' as regras sociais, ou aqueles que estão fora de si de raiva" (Viveiros de Castro 1986:475). Kaaki, enquanto consciência e percepção, configura-se, portanto, como atributo da $i$ ativa. Viveiros de Castro (1986), por sua vez, aproxima kaaki da noção "alma-palavra” Guarani expressa pelo termo nhe'e, que “[...] constitui o princípio agentivo que confere a cada pessoa capacidades de expressão e compreensão" (Macedo 2011:2). Os -nhe-e são componentes da pessoa e de outros sujeitos e podem ser traduzidos como princípio vital (Testa 2014:252). Após o nascimento o -nhe-e é frouxamente ligado ao corpo (-ete) do recém-nascido, e a partir daí tudo deve ser feito para concentrá-lo junto ao corpo, sob risco de morte. A ligação do -nhe-e ao corpo garante a permanência na terra. Após a morte, o -nhe-e deve retornar ao seu lugar de origem celeste (op.cit.:252-54). O pensamento estaria então configurado como capacidade e princípio agentivo.

Partindo de etnografia Airo-Pai, povo indígena residente na Amazônia peruana, Belaunde sublinha que pensamentos circulam pelo corpo através do sangue e geram uma capacidade produtiva e de cuidados efetivos entre os parentes (2006:211). Para os Awajun, povo que também reside na Amazônia peruana, "comida, objetos, palavras, música, cheiros e crianças produzidos são manifestações da boa circulação dos pensamentos de uma pessoa, exteriorizados na realidade física por meio de seu trabalho habilidoso e esforçado" (op.cit.:211). A ausência de pensamento acarreta falta de capacidade produtiva, preguiça, esquecimento, e portanto gera, no limite, a ausência de relação com parentes. Já entre os Caxinauá, pensar, expresso pela categoria xinan, alude a estados de consciência, lembrança que acompanha o amadurecimento da pessoa e se configura tanto como uma força responsável pela concentração de componentes da

\footnotetext{
${ }^{172}$ O verbo - $k a$ significa "ser, ter, estar" (Viveiros de Castro 1986:475).
} 
pessoa, os yuxin, ${ }^{173}$ como sua abertura e dispersão (Yano 2010:131-35). Pensar e lembrar, portanto, propulsiona a ação e a criação de relações e confere capacidade, características fundamentais na dinâmica de constituição de saberes.

Quando os Djeoromitxi dizem que “[...] no pensamento guardamos o que sabemos fazer, no pensamento guardamos a fala nossa, que é essa de aconselhar, de conversar, falar nomes de animais" (Soares-Pinto 2014;265); quando um homem Guarani Mbya indica que tem a lembrança de seus filhos plantando árvores em determinado local quando eram pequenos (Testa 2014:260); ou quando um jovem líder Kisêdjê preocupado com a diminuição de variedades plantadas na roça diz que "[...] se as pessoas não 'pensam' nas plantas nem ‘cuidam' delas, elas irão embora” (Coelho de Souza 2014:212), fica claro que pensar não se configura como um atributo restrito ao intelecto e que carrega a capacidade de agência com influência decisiva no modo como esses povos constituem a vida, as relações e as coisas. Essa capacidade, inclusive, tampouco parece estar restrita aos humanos, como veremos adiante.

Entre os Awá-Guajá, imarakwá pode ser traduzido por '“[...] 'pensar', 'lembrar', 'imaginar'; e até mesmo 'planejar', 'arquitetar', 'tramar', ou qualquer outra atividade que denote uma ação de um indivíduo baseado em reflexão prévia dessa ação (o que chamamos de 'pensamento'). 'Pensar' é uma boa tradução linguística, mas não estou certo de que seja a melhor tradução, pois, se concordamos que em ima-r-akwá a raiz da palavra é akwá, (cuja tradução é 'saber/ conhecer'), tendo a fazer uma leitura 'ingoldiana' e traduzir o termo imarakwá como 'processos de conhecer' ou 'formas de saber', ou 'o pensar', isto é, uma tradução que evoque a ideia de atividade e ação [...]. 'O pensar', para os Awá, está relacionado à consciência da ação e ao modo de intervir e se relacionar com as coisas. Os Awá dizem que os animais que mais pensam são os mais difíceis de caçar, e os mais cobiçados" (Garcia 2010:336). Assim, pensar está além de uma operação do intelecto, pois evoca modos de agir e conhecer.

Outra fonte de ampliação de "pensamentos", ensinamentos e de estabelecimento de redes de relações sociais é o sonho entendido como um “[...] plano privilegiado da

\footnotetext{
${ }^{173}$ Vários yuxin habitam o corpo de uma pessoa pano. Essa é uma noção que foi abordada como "alma", "espírito", "força vital" ou "duplo". Os yuxin são componentes da pessoa dotados de consciência e intencionalidade. Essa é uma noção complexa cujo entendimento não é completamente consensual entre os estudiosos pano (Yano 2010:67, 71-72).
} 
comunicação entre os humanos propriamente ditos e as mais diferentes espécies animais (e outras categorias ontológicas, como os ogros e os espíritos)" (Lima 1996:28).

Durante o sonho são vivenciadas experiências que compõem a vida cotidiana. Em muitos casos, os efeitos do sonho não terminam quando o sonhador acorda. Nos sonhos as almas, os duplos vivenciam experiências a partir de nexos relacionais, em tempos e espaços outros, ou seja, outras esferas do cosmos, e entram em contato com seres e domínios a que normalmente não teriam acesso em "estado de vigília", como relatado por Gonçalves em sua etnografia pirahã. Assim, o sonho é tratado como campo de experiências e fonte de conhecimentos (Gonçalves 2001:265-303).

Para os Araweté, sonho, morte e doença são situações que colocam os xamãs em contato com os Maï e são denominados "coisas de saber" (Viveiros de Castro 1986:534). Os cantos dos Maï são uma atividade por excelência dos xamãs. Os Maï cantam pela boca dos xamãs quase todas as noites. "O canto é uma função do sonho e/ou da ingestão de tabaco. Normalmente, a geração de um canto segue esta sequência: um homem dorme, sonha, acorda, fuma, e começa a cantar, narrando o que viu e ouviu no sonho [...] (op.cit.:542). O sonho é, portanto, canal de comunicação direta com os Maï. Para os Parakanã, que não possuem a figura do xamã, o xamanismo se manifesta como capacidade de sonhar. O sonho se configura como um campo de interação do "duplo" do sonhador com outros (akwawa) que, de forma genérica, estão na categoria de inimigos e não pertencem ao universo de parentes. O sonho é um espaço de "familiarização" dos outros - vegetais, animais, entre outros - que aparecem nessas situações como capazes de interação e intenção. No entanto, esses seres sob o controle do sonhador podem ser trazidos para a cura de alguém que está doente via canto. Esses inimigos "familiarizados" atuam, na verdade, como xamãs que podem tanto curar como voltar-se contra os Parakanã (Fausto 2001). Os duplos, almas engajados desencadeiam acontecimentos que se completam em outra esfera enquanto experiência sensível, isto é, como um estado mesmo de vigília - embora esteja em vigília também no sonho.

Por estar em outro estado, as pessoas no sonho têm uma visão alterada das coisas e entram em contato com a agência alheia (Figueiredo 2010:228-29). Os sonhos, como uma espécie de "viagem" do princípio vital, decorrem, para os Wajãpi, da atração dos homens por não humanos. No sonho, a pessoa, esvaziada de seu princípio vital, fica 
leve $\mathrm{e}^{174}$ e perde o controle de si, tornando-se, assim, muito vulnerável (Gallois 1988:14647). O relato de um interlocutor Akuriyó Jara mostra que os sonhos (yeneka), quase sempre associados à caça, são uma forma de atividade equiparada a viagens, onde os protagonistas são transformados e assumem outro ponto de vista em relação a sua posição no "estado de vigília". Nesse sentido, "el püjai ${ }^{175}$ puede percibir a los cerdos salvajes, al tapir e a los otros animales como si se tratase de gente: sus lugares de habitación y de forraje como si se tratase de aldeas o plantíos, y que los alimentos de los animales toman la apariencia de carne cocinada, de bebida y pan elaborado. En otras palabras, el encuentro entre el cazador y los animales durante yeneka y entre el chamán y los habitantes del bosque es un encuentro definido en el contexto de las relaciones sociales" (1990:172). Os sonhos propiciam encontros onde ocorrem mudanças e deslocamento de posições, portanto são vivências que ampliam as experiências e, consequentemente, os modos de conhecer.

Para os Yanomami, os xapiripë - denominados "espíritos", "outros", "experiências" e "relações" - são "[...] o fundo que vem à tona no xamanismo, no sonho e na alucinação, quando o humano e o não humano, o visível e o invisível trocam de lugar" (Viveiros de Castro 2006:326). Em uma narrativa de Davi Kopenawa Yanomami sobre as palavras dos xapiripë, ele conta que “[...] são elas que aumentam nossos pensamentos. São elas que nos fazem ver e conhecer as coisas de longe, as coisas dos antigos. É o nosso estudo, o que nos ensina a sonhar. Deste modo, quem não bebe o sopro dos espíritos tem o pensamento curto e enfumaçado; quem não é olhado pelos xapiripë não sonha, só dorme como um machado no chão" (op.cit.:320). Entre os Yudjá, em um relato sobre um xamã magnificado foi dito que "Senã ã ${ }^{176}$ pretendia ensinar o xamã a tornar-se o ser que ele é; deu-lhe uma mala onde deveriam ser guardadas as coisas fabricadas em sonho, até que ao fim do aprendizado o finado já não acordaria desmunido. Já não retornaria de suas viagens oníricas de mãos abanando, mas com a mala. Estaria assim capacitado a transportar para esse mundo as imagens oníricas das coisas fabricadas e a ensinar o ofício aos outros" (Lima 2005:64). Os sonhos são, portanto, fontes de aprendizado, de contato com outros tipos de gente e de experiências marcadas tanto pela

\footnotetext{
${ }^{174}$ Entre os Araweté, tristeza e saudade, principalmente, mas também um susto e tomar muito sol deixam o corpo leve e assim facilitam a saída da $i$ (princípio vital) do corpo, indicada pela magreza excessiva, por exemplo, e podem ser sinal de falta de saúde e perigo. A leveza é indicada apenas ao xamã. A alegria os traz de volta a si mesmos e ao presente (Viveiros de Castro 1986:478-80).

175 Püjai, xamã.

176 Senã'ã, xamã magnífico que soprou a humanidade e tudo o que tem no mundo (Lima 2005:25).
} 
descontinuidade como pela conjunção de tempos e espaços outros.

Os acontecimentos ocorridos nos sonhos podem influenciar diretamente a constituição de corpos, como entre os Aweti, onde, sobretudo em períodos de reclusão, quando um rapaz deseja sonhar que está empurrando uma pedra, é sinal de que se tornará campeão de luta; ou um contrafeiticeiro deve sonhar com um jatobá, identificado com a força e a potência, o que o torna mais eficaz em seu contrafeitiço (op.cit.:228-29). O seu duplo, no caso, torna-se agente que contribui com a constituição de corpos. Assim, os sonhos $^{177}$ acarretam efeitos diretos na vida, como quando, após ingerir ervas para engravidar, uma mulher aweti deve ficar atenta a seus sonhos, que trarão indicações sobre o sucesso de sua empreitada e o sexo da criança em gestação (op.cit.:230); ou quando um caçador awá sonha com onça, situação que indica prenúncio de boa caçada (Garcia 2010:355). Jara também mostra, entre os Akuriyó, que os acontecimentos dos sonhos incidem sobre o "mundo da vigília", como a indicação de um animal a ser caçado no dia seguinte; a gestação de uma criança filha do espírito da água, que é fruto de encontro ocorrido em sonho; ou a ocorrência de uma forte enfermidade por ter sido flechado por um espírito enquanto sonha. Esses efeitos indicam que "el sueño no es un estado de inactividad o pasivo sino una manera de acceder a una experiencia particular del mundo y de modificarlo. Este mundo de los sueños no es postulado como un mundo extraño sino precisamente como el mismo mundo de vigilia" (1990:171). Para os Yudjá, a iniciativa de uma caçada, por exemplo, pode ter sido sonhada pelo caçador, e os acontecimentos ocorridos no sonho podem refletir então em outras esferas da vida. Enquanto o caçador dorme, a alma procura "[...] aventuras em terra alheia, onde muitas vezes o que vigora é o ponto de vista, a palavra ou a verdade do outro" (Lima 1996:39). No dia seguinte, se o caçador se lembrar de que abateu porcos no sonho, pode significar tanto uma caçada empreendida pela alma em outra esfera quanto uma caçada que se realizará, o que enseja um alargamento do tempo e do espaço nos dois sentidos. "O sonho não é um espelho onde o caçador veria o seu futuro, mas uma linha paralela de tempo onde a alma do caçador se engaja em um acontecimento novo. Não há nem encontros acidentais, nem encontros determinados pelo destino" (op.cit.:40).

\footnotetext{
${ }^{177}$ Os sonhos podem ser provocados, não são necessariamente espontâneos. Para os Araweté, os sonhos ordinários - esse nome pode ser atribuído aos sonhos que não são dos pajés - podem ser provocados por cócegas exageradas. Duas irmãs estavam brincando de fazer cócegas. Sua mãe pediu para parar, pois, caso contrário, iriam sonhar muito à noite.
} 
Os sonhos, portanto, abrem possibilidades para novas experiências, que podem tanto trazer riscos para a vida quanto criar e fortalecer corpos e relações sociais. A agência da alma, duplo ou princípio vital nos sonhos cria a possibilidade de estabelecer relações em outras esferas e tempos, e, com isso, possibilita o aprendizado de cantos (Macedo 2011:16), curas, entre outras coisas, quando captam sentidos outros ao se posicionar a partir de outros pontos de vista.

Outra forma de aprendizado ocorre pela transmissão oral. Por meio de conversas e narrativas as pessoas acessam pensamentos, sonhos, acontecimentos e experiências vividas pelos outros. Nem tudo precisa ser experimentado para tornar-se conhecido e, por outro lado, nem tudo deve ser enunciado. Para os Parakanã, por exemplo, não se deve contar quando se sonha muito, pois caso essa situação se torne pública corre-se o risco de ser acusado de feitiçaria (Fausto 2001); ou os anent achuar, que são cantos mágicos considerados quase como tesouros pessoais transmitidos pelos parentes próximos do mesmo sexo. Assim, os anent devem ser cantados na solidão da roça para mobilizar espíritos auxiliares com o objetivo de garantir sucesso no plantio, e não devem ser cantados em presença dos outros (Descola 2005:274).

A palavra, a depender do modo e da condição de enunciação, é acionada como potência agentiva como em cantos, benzimentos (Lolli 2010:90 apud Cabral de Oliveira 2012:190), para o crescimento de plantas na roça (Descola 2005:273), para cura de doenças (Cabral de Oliveira 2012:190-91), entre outras situações, conforme abordado brevemente no capítulo II. A palavra, portanto, é capaz de transmitir saberes, produzir transformações nos corpos e criar dimensões de socialidade. A eficácia da palavra decorre, em grande medida, da capacidade de acionar seres e suas potências ou manipular as qualidades enunciadas a fim de transmiti-las às pessoas (Cabral de Oliveira 2012:191-92), bem como da cadeia de enunciação, que confere legitimidade a esse conhecimento, tema que será abordado a seguir.

O foco aqui, entretanto, são também as conversas que acontecem para planejar o dia, ao amanhecer, os relatos de caça, das atividades realizadas na roça, das visitas à cidade, das histórias dos mais velhos, que ocorrem cotidianamente, durante as refeições, sem hora marcada para acontecer, sem procedimentos formalizados. 
Os homens araweté antes de saírem para uma caçada, por exemplo, conversam sobre os locais onde planejam caçar naquele dia, os animais que pretendem caçar, os caminhos, seus marcadores, como determinadas árvores ou cursos de rio que compõem uma descrição dos lugares por onde circulam, as atividades que executam e as relações que estabelecem. Ao retornar da caçada, já em casa, contam como foi o dia, por onde caminharam, o que e quem encontraram no caminho, os rastros, como conseguiram apreender a caça, conversa essa que terá maior rendimento durante as refeições. Maizza (2009:33) também cita relatos de caça e descrições de caminhos feitos pelos Jarawara como uma forma de fazer os ouvintes se orientarem no espaço, mesmo se nunca andaram naquele lugar, e, por isso, considera essas conversas uma forma de transmitir “[...] uma aprendizagem sobre o território aos que escutam [...] os lugares, construídos individualmente, passam a ser compartilhados pelo grupo por meio dos relatos de caça”.

Por sua vez, momentos de conversas entre as mulheres araweté, situação corrente entre outros grupos de mulheres indígenas, ocorrem em produções mais coletivas, como quando descascam e torram macaxeira, ou quando os homens saem para caçar e elas ficam com as crianças nas aldeias e se juntam a outras mulheres, suas parentes próximas, para uma refeição, por exemplo. Essa circunstância propicia a troca de informações, a fofoca, muitas risadas e, por sua vez, aprendizados.

Mostrar e contar alguma coisa a alguém é fazer esta coisa se tornar presente para outra pessoa, de modo que, de alguma maneira ela também possa apreendê-la. O contar, por sua vez, não ocorre em qualquer lugar, e tampouco de qualquer maneira. Conversar não se restringe ao falar, ou falar qualquer coisa em qualquer lugar. Relatos de caça, por exemplo, são falados abertamente nas situações descritas acima. As mulheres, por sua vez, não se pronunciam abertamente em espaços de maior circulação, como os pátios das casas. Conversar implica lembrar, não deixar esquecer e, mais do que qualquer coisa, estar junto, compartilhar. À parte relatos que ensejam perigos e que, portanto, devem ser silenciados, contar agrega sentido ao pensar e ao sonhar, pois, além de reforçar as relações instituídas nesses contextos, estabelece vínculos e compartilha conhecimentos e experiências entre narradores e ouvintes, posições essas intercambiáveis, vindo a compor processos de constituição de saberes entre os ameríndios. 
Vale assim reforçar que pensar, sonhar e contar são formas potentes de aprendizado e de estabelecer relações nos contextos ameríndios.

\section{Quem sabe}

Diversas vezes, ao indagar sobre alguma coisa aos Araweté, especialmente sobre Maï ou "histórias dos antigos", a resposta dada era: "Não sei, Tatua ru é quem sabe!", ou "Só velho sabe!" - Tatua ru era o mais velho da aldeia Ta'akati -, ou diziam simplesmente, o que era muito corrente: "Não sei". Ao indagar a Hawoti, jovem recémcasado Araweté, sobre o nome de uma vagem, ele responde: "Só velho sabe!". Os saberes entre os Araweté são bastante difundidos, não há segredos ou espaços reservados exclusivamente aos representantes de certo gênero. Há, por sua vez, atividades executadas principalmente por homens, como a caça, e pelas mulheres, como pilar milho e tecer saias, por exemplo. A prerrogativa de execução de atividades por homens ou mulheres, não indica segmentação de saberes, uma vez que estão disponíveis para serem acessados e são disseminados e compartilhados cotidianamente (Cabral de Oliveira 2006:239), mas essa situação, no entanto, direciona a intensidade na experimentação e vivência desses saberes e, consequentemente, a legitimidade em sua transmissão e enunciação.

Para os Araweté “os velhos sabem, são gente de saber (me'e kôa hã), e não têm medovergonha" (Viveiros de Castro 1986:309). A legitimidade conferida aos saberes e enunciados dos mais velhos está também relacionada ao fato de terem passado por processos de amadurecimento do corpo. O que os mais novos desconhecem, pois ainda não têm maturidade suficiente para absorver certos conhecimentos, ou mesmo aquilo que não têm autoridade para falar, recorrem aos velhos como conhecedores. Por sua vez, para aprender, é fundamental escutar, como dizem os Araweté, e os mais novos devem sempre estar abertos a escutar. As palavras dos velhos são mais potentes, carregam legitimidade e autoridade. O corpo aprende a partir da experiência, mas, como ressalta Yano, para os Caxinauá não se trata de simples acúmulo de experiência, a qual “[...] depende, contudo, para sua boa absorção, da maturidade corporal-intelectual da pessoa ao mesmo tempo que se inscreve em seu corpo e o modifica, concorrendo, por seu turno, para aquele amadurecimento" (2010:96). 
“Se o conceito de 'histórias dos antigos' (pirowï'hã mo-erape ) existe no discurso Araweté - e se refere a uma miscelânea de 'gêneros': mitos etiológicos e divinos, histórias de guerras passadas, feitos dos ancestrais, uma longa saga de seres titânicos não se pode considerá-lo, pois os Araweté assim não o fazem, como designando um saber tradicional e impessoal. [...] Os Araweté, sempre que referem qualquer evento que não tenham presenciado, pospõem: 'assim disse fulano"' (Viveiros de Castro 1986:62). Esses saberes devem sempre ser referenciados, e esse procedimento garante sua legitimidade. Um reconhecido caçador da aldeia araweté Ta'akati sempre dizia que as árvores não tinham dono. Certo dia, participou de uma conversa com Tatua ru em que ele falava sobre as matas, as árvores e sobre histórias dos antigos. Tatua ru então disse, de forma genérica, que Ani era dono das árvores (cf. indicado no capítulo I). Passados alguns dias, quando estávamos acampados na mata para uma caçada coletiva de jabotis, ele veio me mostrar uma árvore. Então perguntei se essa árvore tinha dono, e ele prontamente respondeu que era Ani. Sua esposa, mais que depressa, reprovando a resposta do marido, tratou de dizer que aquela árvore "não tem dono, não". Ele então ficou sem graça diante do ocorrido e logo saiu de perto. Como essa narrativa havia sido contada por Tatua ru, o referido caçador não quis contradizer sua informação, dado que sua palavra é imbuída de autoridade, mas, de fato, não era assim que concebia, ao menos aquela árvore.

"Quando o assunto de que se fala é algo cotidiano ou corriqueiro - e sobretudo quando se trata de mexericos - a impressão é a de um cauteloso descompromisso do falante com a veracidade da mensagem. Mas, quando se está falando de algo 'invisível' (o mundo dos deuses, o começo do mundo etc.), o efeito é a atribuição de uma autoridade toda própria [...] àquele que 'disse'. Disso derivam dois traços da política discursiva Araweté: em primeiro lugar, a importância dos que eles chamam de pirowï’hã nec ã he $r \underline{e}$, 'os que viram os ancestrais' - isto é, os velhos do grupo, que viram, ou ouviram de quem viu, os fatos passados. Em segundo lugar, isto dá a força da palavra do xamã” (op.cit.:63). Assim, se por um lado, nesse caso, trata-se de uma modalidade discursiva que não é impessoal, por outro pode haver variações nas versões narradas. Diante desse contexto, não se deve buscar uma narrativa verdadeira, pois, se todas as versões são referenciadas a alguém, fica evidente que a transformação é inerente à cadeia de 
transmissão. As diversas narrativas compõem modos de enunciação araweté, cuja incompletude ${ }^{178}$ marca sua renovação e vitalidade.

No caso do xamanismo entre os Araweté, homens, mulheres e até crianças falam desse tema abertamente, diferentemente do que ocorre entre Guarani Mbya, onde a circulação desses saberes é controlada (Testa 2014:131). Viveiros de Castro então observa que não há "[..] ninguém menos indicado para discutir e comentar os cantos xamanísticos que aqueles mesmos que os produziam. Um xamã não só se comporta como se ignorasse o que cantou como não gosta de falar diretamente do conteúdo dos cantos e visões alheias. O sentimento de vergonha aí envolvido está associado [...] exatamente ao estilo do discurso citado [...] é mais fácil, ou mais próprio, falar do que disse o outro, abolir-se como fonte primeira do discurso, impedir a coincidência entre o sujeito do enunciado e o sujeito da enunciação. Tudo se passa como se a palavra Araweté fosse sempre a palavra de um outro" (Viveiros de Castro 1986:64-65). Vale aqui pontuar que, mesmo que os xamãs não sejam aqueles que contam sobre os seus cantos, é por meio deles e referindo-se a eles que os cantos e a comunicação com os Maï são referenciados, portanto é a partir deles que emana a autoridade relativa a esses saberes.

Karai Guarani Mbya, com relação aos conhecimentos sobre o xamanismo, disse que “[...] são saberes que não se criam aqui e que os deuses enviam gradativamente. Nenhuma pessoa consegue saber tudo e reunir todos esses saberes, porque eles não 'entregam' assim” (Testa 2014:129). Esses saberes foram criados pelos demiurgos e devem ser acessados junto aos "deuses" por cada um. Vale dizer que esses saberes, entre os Guarani Mbya, são transmitidos gradativamente de modo que "[...] nenhuma pessoa consiga reunir todos os saberes" (op.cit.:130). Por outro lado, há saberes que circulam no âmbito das atividades ligadas à produção cotidiana da vida, onde, ainda entre os Guarani Mbya, é indicado “[...] que para aprender era imprescindível seguir os mais velhos, andar com eles por onde fossem, observar o que faziam, como falavam, e trabalhar junto com eles. Isso tanto para a atividade de plantio, caça, artesanato, preparação de alimentos e remédios como para aquelas atividades xamânicas que são possíveis de aprender acompanhando um rezador mais experiente” (op.cit.:132-33).

\footnotetext{
${ }^{178}$ Carneiro da Cunha afirma que tanto o saber científico quanto os saberes tradicionais são "[...] obras abertas, inacabadas, se fazendo constantemente" (2009:302).
} 
Com isso, mais uma vez é reforçada a autoridade dos velhos na dinâmica de transmissão de conhecimentos.

Entre alguns povos indígenas, como os Tuyuka, na região do rio Negro, a legitimidade da transmissão e mesmo da detenção de conhecimentos relacionados a benzimentos e festas, por exemplo, está pautada em "[...] uma ordem de senioridade segundo funções, entre bayaroa e kumua (dançadores e benzedores), ou entre irmãos maiores (primeiros) e menores (ajudantes do dançador ou ajudantes do benzedor) com base na relação entre linhas nomeadas" (Cabalzar 2010:123). Entre os Tuyuka, cada sib detém determinado arcabouço de conhecimentos e nomes (op.cit.:127). A despeito de contextos onde a transmissão de conhecimentos está mais vinculada à organização sociológica, fator que garante sua legitimidade, como entre os Tuyuka, no rio Negro, e que, como vimos, ocorre de outro modo entre os Araweté, pretende-se aqui tratar de como é conferida maior legitimidade a determinados conhecedores do que a outros. Então um velho Tuyuka diz que "[...] o que sabia falar, era porque ouvira dos mais velhos de todos falando, de tal modo que quase ninguém mais hoje em dia teria escutado e poderia, portanto, falar" (op.cit.:194). Ter, portanto, escutado e visto os mais velhos contarem, por exemplo, confere legitimidade e autoridade aos conhecedores.

Nesse sentido, Oliveira apresentada uma situação em que se confrontam regimes de conhecimentos wajãpi e científico e conclui que "[...] no contexto wajãpi a experimentação se refere ao que os nossos sentidos podem captar, bastando que haja uma única experiência para que um saber seja legitimado e percorra uma cadeia de transmissão" (2012a:69). Diante disso, a experimentação seria o pilar fundamental da legitimação dos saberes wajãpi. Sem dúvida, a experiência constitui uma das bases fundamentais na constituição de conhecimentos em "sociedades" orais, mas se a produção da vida é pautada por experiências e experimentações, por que alguns conhecedores têm mais autoridade que outros?

A questão é menos "o que sabe", dado que esses conhecimentos não são tratados como verdades objetivas (Carneiro da Cunha 2009:301), e mais a legitimidade e a autoridade dos conhecedores, que é conferida, pelo que foi indicado, pela cadeia de transmissão 
oral devidamente referenciada, ${ }^{179}$ pela maturidade do corpo $^{180}$ e pela intensidade da experiência (op.cit.:365) ${ }^{181}$, ou seja, por ter visto, ouvido, falado, sentido ou feito. A experiência também pode ser corroborada por outros marcadores, como a presença de uma árvore que reaviva a memória sobre os acontecimentos e assim indica a própria passagem do tempo. A experiência é acompanhada, portanto, de lembranças, tanto daqueles que viveram como daqueles que ouviram dizer. A autoridade dos conhecedores, no entanto, não emana por si só, ela decorre também da posição ocupada, da forma como se porta, e, especialmente, do reconhecimento pelos outros da cadeia de transmissão. Essa situação pode ser mais bem observada, por exemplo, quando da eficácia da fala de um chefe ou liderança, que está relacionada tanto ao modo como o chefe se coloca, a forma como pronuncia e age, como também ao reconhecimento pelos outros de sua posição (Testa 2014:207; Guerreiro 2012:301). Se, em alguma medida, os saberes são compartilhados, a autoridade sobre eles é conquistada, posicionada e, muitas vezes, fragmentada (Carneiro da Cunha 2009:363) e, para ter efetividade, deve ser reconhecida pelos outros.

\section{Ritmos e intensidades nos aprendizados}

Ao sair pela primeira vez com os Araweté da aldeia Aradjyti para caçar jabotis, me surpreendi com o ritmo pausado da caminhada e com algumas paradas para descanso. Ao chegar na aldeia, comentei essa sensação com Japiwin, que me disse: "A gente não aprende rápido, é devagar". Essa fala, obviamente, não está relacionada à capacidade intelectual de aprendizagem, mas muito mais com modos de conhecer e incorporar conhecimentos.

Como Garcia (2010:58) também observou entre os Awá, talvez por motivos diversos, a parada também está presente nas caminhadas pelas florestas. “[...] o território é marcado

\footnotetext{
${ }^{179}$ Coelho de Souza alerta sobre o processo de "desparticularização" dos conhecimentos, no caso, kisêdjê, em projetos contemporâneos de registros de conhecimentos por pesquisadores indígenas, quando "[...] conhecedores precisam ser desparticularizados; devem aparecer como "anciãos kisêdjê", mas (não) mais parentes de algumas pessoas e não (ou menos) de outras [...]" (2014:213).

${ }^{180}$ Frazão-Moreira identificou entre os Nalu que os conhecimentos sobre os vegetais aumentam ao longo da vida e que há nomes e características que são dominados apenas pelos mais velhos (2001:147).

${ }^{181}$ Carneiro da Cunha indica que na Melanésia "[...] o conhecimento está fundamentado na autoridade da fonte. Já na Amazônia, [...] é a experiência direta que prevalece" (2009:365). No entanto, diante dos exemplos etnográficos, esses dois pressupostos são válidos mesmo na Amazônia, podendo estar presentes ou não, a depender do contexto de transmissão de conhecimentos.
} 
pela memória, e cada trilha tem os seus pontos de parada para a caminhada quase predefinidos, isto é, são sempre os mesmos: um grosso tronco há muitos anos derrubado serve como banco; uma beira de igarapé ou um antigo acampamento são utilizados como ponto de parada. Por ser a floresta um local perigoso, tanto pelos seres visíveis (onças e cobras, por exemplo), quanto por invisíveis (sobretudo os fantasmas ajy), tais paradas são como locais certificados contra fantasmas, vinganças mágicas de animais e outros perigos. Sítios onde os riscos são menores justamente por serem de constante presença humana".

Algumas vezes os Araweté ficaram receosos de me levar em alguma caçada de jaboti, atividade de que as mulheres participam ativamente, pois, do seu ponto de vista, eu não sabia andar nas florestas, podia fazer barulho e assim espantar os animais, estaria mais sujeita a perigos e, portanto, daria mais trabalho e dificultaria a caçada. Sem dúvida os Araweté tinham razão, pois eu não havia constituído essa experiência, e a minha presença atrapalharia o ritmo e, consequentemente, o sucesso da caçada, que dependia de um movimento harmônico entre o casal. Enquanto o homem andava na frente, abrindo o caminho, a mulher circulava no seu entorno procurando indícios de jabotis.

Músicas, cantos, ciclos rituais, formas de enunciação, a passagem do tempo marcada pelo verão e pelo inverno, o crescimento dos seres, entre muitas outras coisas, envolvem ritmos e intensidades cruciais à incorporação de conhecimentos. Perceber o movimento de seres e coisas e caminhar em ritmos adequados a essas dinâmicas constitui e é determinante nos modos ameríndios de aprender. Ritmos estão vinculados à percepção. Não se percebem nas florestas ritmos acelerados, a não ser quando uma manada de queixadas se sente ameaçada e sai em disparada, por exemplo.

A pausa e o silêncio também fazem parte do processo de aprendizagem e do saber andar nas florestas, e são fundamentais para a percepção do entorno. Parar em meio a uma caçada e descansar, conversar e observar o que e quem está em volta é fundamental ao processo de "educação para a atenção".

O ritmo e a intensidade marcam a eficácia na interação entre as pessoas, como observado no discurso de um chefe kalapalo: “[...] o tom de voz, o ritmo e a melodia devem ser controlados, a respiração deve ser regular, o corpo deve estar posicionado de 
maneira correta, a cabeça, os olhos e as mãos só se movem segundo um código de respeito e vergonha. [...] a fala deve ser feita no tom apropriado, geralmente baixo, e cada linha, executada após uma breve pausa para a respiração (uma das piores coisas que se pode fazer é interromper a execução de uma linha). Discursar é uma performance ritual completa, cuja estética, tudo aquilo que a audiência percebe, envolve a fala e o corpo do executor em todos os seus aspectos. O que se apresenta em uma ocasião como esta não é apenas uma fala, mas uma pessoa por inteiro, alguém que, no que diz e na forma como se porta, se coloca como uma pessoa não trivial" (Guerreiro 2012:303). Entre os Mbya, a fala e, consequentemente, a escuta devem ser desenvolvidas de forma gradual, como quando se narra uma história e essa é contada por partes, por ser muito longa; ou pelo aprendizado gradual com relação à absorção de conhecimentos sobre o uso de vegetais em práticas terapêuticas (Testa 2014:151-52,156). Enfim, o processo de incorporação de saberes é ritmado, e essa dinâmica garante sua assimilação.

Ritmos e pausas fazem parte da vida e dos ciclos dos seres e coisas que compõem os mundos, como o período de chuva e seca, a floração das árvores, a produção de frutos, a reprodução dos seres, as épocas para a coleta de mel, para a caça de cada animal, para a pesca de tipos de peixes, e por isso são fundamentais aos modos de constituir saberes entre os ameríndios.

Por sua vez, a intensidade e a recorrência das ações indicam a potência e o vigor do engajamento envolvido nas coisas. A intensidade marca, por exemplo, o processo de aprendizado para tornar-se pajé, quando o consumo frequente do tabaco é fundamental na fabricação do corpo (Viveiros de Castro 1986:531; Figueiredo 2010:233), nas atividades cotidianas, quando mulheres araweté todos os dias, praticamente, tecem suas saias e durante horas ficam ajoelhadas na mesma posição, ou mesmo nos ritos de passagem e nos momentos de resguardo, como quando meninas e meninos passam pelo rito em que recebem picadas de formigas no corpo para confirmar sua força e assim não ter preguiça (Gallois 1988:134-38).

Para os Guarani Mbya, por sua vez, “[...] as pessoas adquirem diferentes tipos, intensidades e quantidades de saberes, segundo as condições distintas que desenvolvem no acesso a sua circulação. Estas distinções remetem principalmente às experiências específicas que as pessoas podem ter ao percorrerem os caminhos próprios que 
constroem em busca dos saberes" (Testa 2014:131). Os velhos Guarani aconselham os jovens “[...] a não andarem com moleza, mas pisarem com firmeza" (op.cit.:148) quando andam nas matas. Firmeza, em contraposição à moleza, característica dos recém-nascidos, gera a capacidade de orientação, de não se perder nos caminhos e assim evitar perigos indesejados.

Entre os Yanomami foi observado considerável variação acerca de conhecimentos relacionados às propriedades e à identificação de plantas em uma mesma comunidade, e, entre as pessoas de uma mesma comunidade, situação atribuída à transmissão de informações pelos pais, a fatores como sexo e idade e ao histórico familiar de migração (Albert, Milliken \& Gomez 1999:12). Intensidade, portanto, não está associada apenas a excesso, empenho ou veemência, mas também às condições de acesso aos saberes.

A intensidade, no caso, está relacionada às ações direcionadas a processos de fabricação de corpos e à absorção e retenção de saberes pelas pessoas, e está totalmente relacionada à contundência experimentada nas relações e atividades desenvolvidas. Saber dosar regula e dota de eficácia os processos de constituição de saberes, que estão totalmente imbricados nos modos de se relacionar.

\section{Saberes nos corpos}

Entre os ameríndios, saberes não estão separados de seus detentores. Se considerarmos que "[...] o conhecimento reside no corpo. [...] Por isso, não pode haver conhecimento dissociado do seu conhecedor" (Cunha \& Cesarino 2014:14).

Os saberes e experiências são, pouco a pouco, consolidados e concentrados nos corpos. No entanto, como foi apresentado no capítulo III, essa incorporação está totalmente vinculada à produção social de pessoas, que, por sua vez, depende da abertura ao outro, e está permanentemente em constituição, aspecto que indica sua incompletude. Os corpos pintados ou perfurados, resguardados ou devorados são construídos a partir de dinâmicas relacionais e da contínua atualização de experiências sensório-motoras. Os aprendizados e a respectiva incorporação são, assim, constituídos socialmente.

De acordo com Testa, “[...] corpo é entendido como caminho de circulação de saberes, 
pois é uma espécie de lugar-passagem que concentra e por onde fluem substâncias e saberes" (2014:128) que, ao passarem pelo corpo, “[...] afetam-no e afetam os modos como os sujeitos se relacionam" (op.cit.:144). Os saberes, segundo Testa, são potencialmente ambíguos, e por isso seu fluxo deve ser controlado. Como entre os Mbya, onde não se pode contar indiscriminadamente sobre o uso terapêutico de determinadas plantas; ou quando um rezador, por meio de palavras, trata infortúnios, mas se o paciente não estiver aberto a ouvir isso pode se voltar contra o rezador (op.cit.:144). Assim, os saberes podem ser tanto absorvidos como dissipados. No entanto, se nem todo saber é desejado ou apropriado, o próprio contato com esse saber será evitado, na maioria das vezes. Assim, entre os Araweté, homens não tecem saia e mulheres não fumam tabaco para se tornar xamã, por exemplo.

Os saberes penetram e se alocam em determinadas partes do corpo. Se concentrados em partes (Yano 2010:94-95; Cabral de Oliveira 2012:171) ou dissipados pelo sangue, como demonstrou Belaunde (2006) - conforme indicado no capítulo III -, o fato é que é pela incorporação que conhecimentos e códigos são apreendidos e assim se adquire, de forma comedida e gradual, destreza e capacidade de "atenção" (Ingold 2008). Corpos são assim transformados nesse processo, pois, como ressalta Yano, se corpos precisam estar aptos para absorver saberes, o inverso também é fundamental à "fabricação" de corpos e pessoas $(2010: 105,120)$. Se partes do corpo devem ter determinadas características ou mesmo ser preparadas para absorver saberes, como quando Oliveira demonstra que para os Wajãpi a capacidade de aprender um idioma está atrelada à consistência da boca e da língua, as quais devem ser maleáveis (2010:171), ou quando os Araweté estalam uma folha no ouvido dos bebês cujo som remete à aprendizagem da fala; por outro lado, as meninas araweté desde pequenas acompanham as mães na coleta diária de água nas cacimbas, e gradativamente aumenta-se o tamanho dos potes e, consequentemente, do peso que carregam. Assim, seus corpos estão preparados para longas caminhadas nas matas, para carregar pesados cestos de mandioca e milho e, no retorno das caçadas, ser responsável por carregar os jabotis encontrados. (Viveiros de Castro 1986:79). Como diz Oliveira, esse processo de "ensabidamento" do corpo (2012:171), repercute na capacidade de se relacionar e reflete o modo como a pessoa será percebida pelo outro.

Nesse sentido, para andar nas florestas de forma adequada é necessário dispor de um 
corpo apto e estar devidamente posicionado em redes de relações. Por outro lado, é preciso saber perceber uma cobra entre gravetos, rastros de cotia, queixada e outros, e esses engajamentos perceptivos nos mundos decorrem tanto da incorporação de códigos quanto de experiências. As experiências ocorrem, portanto, pela incorporação de qualidades sensíveis nos corpos, que sentem e percebem, seja uma picada de escorpião, o cheiro fétido que indica a presença de queixadas, buracos nas árvores que denotam a casa de $A n i$, uma colmeia assentada no galho de uma árvore, o aroma de certa flor e assim por diante. Por sua vez, esses engajamentos entre corpos também se baseiam em sistemas de significados compartilhados.

A produção de corpos e a incorporação de conhecimentos são, portanto, condicionadas, mas também dinamizadoras, às dinâmicas relacionais e às experiências sensóriomotoras. Os conhecimentos absorvidos pelos corpos orientam as ações das pessoas nos mundos (Testa 2014:128). Corpos, de certa forma, não são separados de mundos e constituem a base da experiência incorporada.

\section{Estar e ser mundos}

A produção de conhecimentos em sociedades onde predomina a oralidade está, em grande medida, associada aos mundos experienciados a partir das redes de relações sociais as quais as pessoas estão envolvidas. Pessoas, por sua vez, não são dissociadas nem de relações sociais, nem de mundos ${ }^{182}$.

De acordo com Viveiros de Castro, o pensamento ameríndio está fundado na ontologia da diferença onde os sujeitos "são o mundo, formando seu tecido perspectivo último, e não apenas estão no mundo como dentro de um quadro neutro que precedesse os pontos de vista [...]. Um mundo, enfim, metafisicamente antropofágico, onde a alteridade é anterior à identidade, a relação superior aos termos, e a transformação interior à forma" $(2012: 157-158)^{183}$. Estar e ser mundo (ou mundos) é mais uma das tantas coisas

\footnotetext{
${ }^{182}$ Em outro sentido, mas que pode ser complementar à explanação que segue, de acordo com Tupã Miri, um Guarani Mbya, ao relatar os cuidados com a placenta e o fato de ser enterrada onde nasce a criança, ato que estabelece vínculo entre a criança e a terra, ambas são concebidas como corpos que se alimentam mutuamente (Testa 2014:257).

${ }^{183}$ Em nota, Viveiros de Castro destaca e enaltece o perspectivismo ameríndio, em relação à abordagem fenomenológica, que "[...] postula uma visão do mundo, o mundo como visão, mundo feito de olhos - de olhos e de bocas - mundo vidente-canibal, onde tudo que há, vê e come" (2012:169).
} 
experimentadas pelos homens, não de forma substancializada, uma vez que "[...] tudo o que ele é ele também não é, pois sua mais constante natureza não é a de ser, mas a de devir" (Wagner 2010:212-213). Trata-se então de mundos e, especificamente na questão aqui abordada, de florestas percebidas e vividas a partir daqueles que as experimentam. Na caça de queixada, os Araweté percebem que estão próximos da caça ao sentirem o cheiro fétido destes animais. Por sua vez, ao irem para a mata para coletar castanha e sentirem o cheiro fétido de queixada, poderão continuar seu caminho à procura de castanha ou decidir caçar queixadas. Queixadas cruzaram seu caminho, sendo que em uma situação os Araweté exercem a plena posição de caça e caçador e na outra, apesar de reconhecerem a oportunidade e estar implícita esta posição, optam pela coleta de castanha. Por outro lado, queixadas podem também atacar os humanos, como já aconteceu com os Araweté. As qualidades sensíveis anunciam potenciais configurações relacionais que podem ser exercidas de diversas maneiras e que são permeadas pela incerteza e pelo improviso. Florestas não são dadas e, tampouco, não são lugares neutros e objetivados que aguardam passivamente serem conhecidas pelos agentes conhecedores. Seres que constituem florestas estão em constante movimento e em processos de interação independentes da participação, agência e presença dos Araweté, Awá etc. Os Araweté, por sua vez, ao andarem nas florestas ficam atentos aos referentes que se anunciam e assim reconhecem os contextos relacionais em jogo. No entanto, nem todos contextos reconhecidos são passíveis de experimentação direta, o que não significa dizer que não são, de alguma maneira, incorporados. Reconhecer as relações que ocorrem de forma tangencial também é fundamental para se andar nas florestas com segurança. $\mathrm{O}$ cuidado é justamente para não negligenciarem as experiências e os modos de perceber dos outros, os quais, de alguma maneira, acabam por constituir a sua própria experiência, de modo menos ou mais intensivo.

Nas ontologias das sociedades amazônicas, "[...] diferentes mundos podem coexistir perceptualmente [...]. Toda percepção do real é fruto de um ponto de vista singular, sem que exista qualquer posição privilegiada. O que é universal não é um conjunto de coisas objetivas, e sim um modo de organizá-las." (Carneiro da Cunha 2009:366) ${ }^{184}$. Se os referentes variam de acordo com o ponto de vista, "[...] a percepção é equívoca quanto

\footnotetext{
${ }^{184}$ Carneiro da Cunha ao elaborar essa formulação refere-se à teoria do perspectivismo ameríndio de Eduardo Viveiros de Castro (cf. Viveiros de Castro 1996:127-128).
} 
àquilo a que se refere e ao mesmo tempo é uma determinante fonte de conhecimento" (op.cit.:367).

Conhecer lugares, como observado por Coelho de Souza entre os Kisêdjê, "reside em comportar-se apropriadamente em (relação a) determinados lugares - nexos de relações que constituem uma população heterogênea, mas interdependente de seres, humanos e não humanos, enquanto contexto espacial e temporalmente determinado que implica parâmetros particulares para qualquer ação. Conhecer um lugar é assim conhecer sua história e seu potencial - o que e quem fez dele um ponto de referência significativo para ações e experiências futuras - e para isso é preciso ou lembrar de histórias, ou ser capaz de ver o invisível e ouvir o inaudível" (2014:201). Lugar é, nesse sentido, abordado como "[...] evento (resultado de ação) e contexto (para ação), como uma conjuntura gerada na interação de seres humanos e não humanos" (op.cit.:204). Conhecer lugares remete às experiências daqueles que viveram e daqueles que narram os acontecimentos ocorridos; é projetar e experimentar encontros e reconhecer as percepções alheias.

Florestas são constituídas a partir de nexos relacionais, os quais lhes conferem sentido e significado. Por outro lado, como mecanismos que se retroalimentam, os modos de conhecer florestas são constituídos a partir de intensas experimentações perceptuais que não deixam de estar localizadas e de ser contingentes, mas que, ao mesmo tempo, ultrapassam as condições materiais imediatamente percebidas. Essa dinâmica enseja a mediação entre convenções e improvisações. Como preconiza Roy Wagner (2010a:96), a agência humana opera na tensão entre invenção e convenção que "[...] mantêm entre si uma relação dialética, uma relação ao mesmo tempo de interdependência e contradição". Trata-se, então, de mundos, ou florestas, constituídos e compostos pelos Araweté, Daribi, Wajãpi, e assim por diante, como diz Viveiros de Castro, "[...] mundos que assim os exprimem" (2002:124).

Entre convenções, improvisos e invenções, andar, caçar, acampar, pescar etc. nas florestas implica em constituir florestas ao mesmo tempo em que se é constituído pelos múltiplos planos relacionais que as compõem. Os mundos e os substratos materiais ali presentes são, então, percebidos como rotas perceptivas a partir de convenções e códigos compartilhados. O modo como os mundos (os seres e as coisas que os 
compõem) são apreendidos e experimentados depende dos nexos relacionais com eles estabelecidos. As dinâmicas das relações, portanto, são intrínsecas a constituição e ao conhecimento de mundos. 


\section{Palavras finais}

A partir de percepções e experiências ameríndias, esta tese procurou desvendar os modos esses povos, em especial, os Araweté, concebem o domínio das florestas. A intenção, como espero ter esclarecido ao longo do trabalho, não era definir florestas com base em generalizações totalizantes, mas atentar para as redes de relações que envolvem estar nas florestas e interagir com as demais gentes que ali habitam.

Ao percorrer essas redes de relações, tomei como eixo norteador os vegetais. Todavia, ao longo de minha curta convivência com os Araweté, a figura do jaboti revelou-se bastante produtiva para refletir acerca dos modos como eles conhecem e experienciam as florestas. É a partir do jaboti, ou, mais especificamente, a partir das caçadas de jabotis que gostaria de pontuar as questões centrais abordadas nesta tese. Caçadas que, muitas vezes, ocorrem para satisfazer o desejo de Mai comer carne de jaboti, conjuntura que revela que experiências que constituem as florestas não estão localizadas em um lugar e ultrapassam a própria camada terrestre. As famílias araweté, então, se mobilizam e orientam pelo que denominam "florestas dos jabotis", noção que não se reduz à identificação de uma porção do território. Jabotis, no caso, são associados à árvores que produzem frutos que eles gostam de comer. Essas caçadas, grosso modo, são conduzidas pela procura dessas árvores pelos homens. Os jabotis, por sua vez, são guiados, de acordo com interlocutores Araweté, pelo aroma de seus frutos e circulam no entorno dessas árvores. Florestas, então, são constituídas a partir de convenções, nexos relacionais e experiências sensíveis e não, simplesmente, pela identificação de porções do território a partir de características físicas ou da presença de determinados "recursos". Florestas são constituídas por caminhos guiados por convenções e improvisações e permeados por negociações, experimentações e potenciais incorporações.

Por sua vez, os vegetais por si só não configuram uma categoria. Os vegetais são então apreendidos a partir de uma multiplicidade de rotas e se configuram, muitas vezes, como índices de relações. Portanto, devemos estar atentos menos ao termo e mais aos tipos de relações estabelecidas. Os vegetais podem, então, ser categorizados como sendo dotados ou não de agência; como seres plantados ou não plantados; entre outras possibilidades de classificações. Os elementos vegetais despontam como índices na 
redes de relações também a partir de suas qualidades sensíveis. A identificação da durabilidade e dureza de um tronco define tanto a sua derrubada para a confecção de uma canoa, o que também marca o lugar onde esta será construída, como a organização da derrubada das árvores para a preparação de um local para o plantio de uma roça. Nesta situação, troncos maiores e mais duros serão derrubados por homens maduros, e troncos mais finos e porosos serão cortados pelos jovens. Desta forma, as qualidades sensíveis dos vegetais norteiam modos de se relacionar e também contribuem com a constituição de corpos e mundos, uma vez que ao derrubar as árvores, florestas e humanos são constituídos mutuamente. As relações entre humanos e vegetais não são, portanto, unilaterais, o que, muitas vezes, implica em campos de negociações.

Um outro ponto a ser destacado, no entanto, é a constatação de que a capacidade dos vegetais de produzirem transformações nos seres com os quais se relacionam decorre, em muitas circunstâncias, de sua vitalidade e não, por sua parte, de intencionalidades. Por outro lado, potências agentivas dos vegetais são acionadas e, com isso, são promovidas curas de enfermidades, sedução, afastamentos ou provocados malefícios e até mesmo a morte, contextos que reforçam a existência de graus de agentividade e, portanto, de intencionalidades. Então, embora todos os corpos estejam relacionados à perspectiva de alguém, nem todos detêm uma perspectiva, pois possuir vitalidade não é prerrogativa de intencionalidade.

Tampouco, ao menos entre os Araweté, a relação de maestria se configura presente em todos os contextos relacionais, nem como controle, nem como cuidado, como indicado nas falas dos Araweté quando se referem aos vegetais encontrados nas florestas e que foram: "simplesmente deixados" ou "abandonados" por Mai. Neste caso, inclusive, sua reprodução é indicada como autocriação: "se criam sozinhos". Por outro lado, os vegetais que foram plantados, especialmente, na roça, devem ser cuidados por alguém para se reproduzirem ou, se foram plantados nas florestas, ao menos, anunciam a presença de alguém e o modo de se relacionar.

Enfim, contextos relacionais operacionalizados por descontinuidades de diversas ordens indicam a multiplicidade das relações estabelecidas com os vegetais e sustentam a adoção da noção de florestas no plural. O equilíbrio destas redes de relações se dá menos por deixar o outro tomar a cena principal sem dele se aproximar, como em 
alguns discursos e práticas ambientalistas, mas por estabelecer conexões, apropriações e aproximações controladas que, por sua vez, proporcionam o desenvolvimento de capacidades e saberes que contribuem com a constituição de si, o aprender a cuidar de si, saber se comportar diante dos outros e a estar atento e manejar os perigos. Essas são, inclusive, características fundamentais para andar nas florestas com segurança e estabelecer relações com aqueles que nela habitam ou se encontram.

Seguir os passos dos Araweté pelos caminhos repletos de histórias, significados e vivências por eles desenhados nas matas, principalmente para caçar jabotis, foram fundamentais no que denomino como processo de constituição de florestas e, consequentemente, o exercício voltado a apreender os modos ameríndios de conhecer as florestas. 


\section{Bibliografia}

ALBERT, B. "O ouro canibal e a queda do céu: uma crítica xamânica da economia política da natureza (Yanomami)". In: B. Albert \& A.R.Ramos (Orgs.). Pacificando o branco: cosmologias do contato no Norte-Amazônico. Ed. UNESO: Imprensa Oficial do Estado. São Paulo. 2002.

ALBERT, B.; MILLIKEN, W.; GOMEZ, G.G. Yanomami: a forest people. The Royal Botanic Gardens, Kew. 1999.

Uruhi A: a terra-floresta Yanomami. Instituto Socioambiental-ISA: São Paulo; Institut de Recherch pour le Devéloppment:IRD: Paris, Fr. 2009.

ALMEIDA, M.B \& CARNEIRO DA CUNHA, M. (Orgs.). Enciclopédia da floresta. Companhia das Letras. São Paulo. 2002.

ARAÚJO, I.M. Osikirip: os "especiais" Karitiana e a noção de pessoa ameríndia. Tese de doutorado, FFLCH/USP, São Paulo. 2014.

ÅRHEM, K. "Ecosofia Makuna". La selva humanizada. F. Correa (ed.). Bogotá: ICANCEREC. p. 109-126. 1993.

Power of place: territory, landscape and belonging in Northwest Amazonia. In: Lowell, N. (ed). Local Belonging. London: Routledge. 78-102. 1998.

"Ecocosmología y chamanismo en el Amazonas: variaciones sobre un tema". Revista Colombiana de Antropología. Vol. 37, p.268-288. 2001.

BALÉE, W. "Nomenclatural Patterns in Ka'apor Ethnobotany". Journal of Ethnobiology, 9(1):1-24. 2005.

Footprints of the Forest. Ka'apor Ethnobotany - the Historical Ecology of Plant Utilization by Amazonian People. New York, Columbia University Press. 1994a.

"Language, Culture, and Environment. Tupí-Guaraní Plant Names Over Time”. In: Anna Roosevelt (Ed.). Amazonian Indians. From Prehistory to the Present. Antropological Perspectives. Tucson, The University of Arizona Press. 1994b.

"Biodiversidade e os índios amazônicos". In: M. Carneiro da Cunha \& E. Viveiros de Castro (Orgs.). Amazônia: etnologia e história Indígena. NHII-USP/ FAPESP, São Paulo.1993.

BASSO, K. "Wisdom sits in places. Notes a Western Apache landscape". Senses of place. S. Feld \& K. Basso (Orgs.). Santa Fe, New Mexico: School of American Research Press. 53-90. 1996.

BECHELANY, F.C. "Ideologia venatória na Amazônia: notas sobre a caça na etnologia das terras baixas da América do Sul". Espaço Ameríndio, v. 7, n. 1, p. 310-344. 2013. 
BELAUNDE, L.E. "A força dos pensamentos, o fedor do sangue. Hematologia e gênero na Amazônia". Revista de Antropologia, v. 49, n 1. 2006.

BENJAMIN, W. "Brinquedo e brincadeira: observações sobre uma obra monumental (1928)". In: Magia e técnica, arte e politica: ensaios sobre literatura e história da cultura - Obras escolhidas v.1. Ed. Brasiliense, São Paulo. 1987, $3^{\text {a }}$ ed.

BERLIN, B., BREEDLOVE, D. e RAVEN, P.. "General Principles of Classification and Nomenclature in Folk Biology", American Anthropologist, 75 (1), 214-242, 1973.

BINDÁ, N. H. Representações do ambiente e territorialidade entre os Zo'él PA. Dissertação de mestrado, FFLCH/USP, São Paulo. 2001.

BLOCH, M. "Why trees, too, are good to think with: towards on anthropology of the meaning of life". In: RIVAL, L (Ed.). The social life of trees: anthropological perspectives on tree symbolism. Berg. 2001 [1998].

CABALZAR, F.F.S.D. Até Manaus, até Bogotá: Os Tuyuka vestem seus nomes como ornamentos. Geração e transformação de conhecimentos a partir do alto rio Tiquié (noroeste Amazônico).

CABRAL DE OLIVEIRA, J.. Classificações em cena. Algumas formas de classificação das plantas cultivadas pelos Wajãpi do Amapari (AP). Dissertação de mestrado, FFLCH/USP, São Paulo. 2006.

Entre plantas e palavras. Modos de constituição de saberes entre os Wajãpi (AP). Tese de doutorado, FFLCH/USP, São Paulo. 2012.

"'Vocês sabem porque vocês viram!': reflexão sobre modos de autoridade do conhecimento". Revista de Antropologia,v. 55, nº 1. 2012a.

CARNEIRO DA CUNHA, M. Cultura com aspas e outros ensaios. Cosac Naify, São Paulo. 2009.

"Políticas culturais e povos indígenas. Uma introdução". In: Carneiro da Cunha, M. \& Cesarino, P. de N. (Orgs). Politicas culturais e povos indígenas. Cultura Acadêmica Ed, São Paulo. 2014.

CAYÓN, L. Penso, logo crio. A teoria Makuna do mundo. Tese de doutorado, UNB, Brasília. 2010.

CLASSEN, C. "Sweet Colors, Fragrant Songs: Sensory Models of the Andes and the Amazon". American Ethnologist 17 (4): 722-35. 1990.

"Fundamentos de una antropología de los sentidos". Revista Internacional de Ciencias Sociales, n. ${ }^{\circ} 153.1997$.

CODONHO, C.G. Aprendendo entre pares: a transmissão horizontal de saberes entre as crianças indígenas Galibi-Marworno (Amapá, Brasil). Dissertação de mestrado, 
PPGAS-UFSC, Florianópolis. 2007.

"Entre brincadeiras e hostilidades: percepção, construção e vivência das regras de organização social entre as crianças indígenas galibi-marworno". Tellus, ano 9, n. 17, p. 137-161. 2009.

COELHO DE SOUZA, M.S. "Parentes de sangue: incesto, substância e relação no pensamento Timbira". Mana 10 (1):25-60. 2004.

"Conhecimento indígena e seus conhecedores: uma ciência duas vezes concreta". In: Carneiro da Cunha, M. \& Cesarino, P. de N. (Orgs.). Políticas culturais e povos indígenas. Cultura Acadêmica Ed, São Paulo. 2014.

COHN, C. A criança indígena: a concepção Xikrin de infância e aprendizado. Dissertação de mestrado, FFLCH/USP, São Paulo. 2000.

"Crescendo como um Xikrin: uma análise da infância e do desenvolvimento infantil entre os Kayapó-Xikrin do Bacajá". Revista de Antropologia, v. 43 n 2. 2000 a.

CORMIER, L.A. Um aroma no ar: a ecologia histórica das plantas anti-fantasma entre os Guajá da Amazônia. Mana 11(1). 2005.

COSTA, L. "Alimentação e comensalidade entre os Kanamari da Amazônia Ocidental". Mana 19 (3). 2013.

DELEUZE, G.; GUATTARI, F. Mil Platôs: capitalismo e esquizofrenia 2. Vol. 1. Ed. $34,2^{\mathrm{a}}$ ed. 2011.

DESCOLA, P. La nature domestique. Symbolisme et praxis dans l'écologie des Achuar. Éditions de la Maison des sciences de l'homme, 1986.

La Selva Culta: simbolismo y praxis en la ecologia de los Andes. Colección 500 Años nº 17. Coedicion Ediciones Abya-Yala e MLAL. 2005. 2 ${ }^{\mathrm{a}}$ ed.

An interview with Philippe Descola - John Knight e Laura Rival.

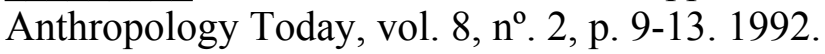

"Constructing natures: symbolic ecology and social practice". In: Descola, P.; Pálsson, G. (Ed).. Nature e society. Anthropological perspectives. Routledge, London. 1996.

"Ecologia e cosmologia". In: Castro, E. \& Pinton, F. (Orgs.). Faces do trópico úmido. Conceitos e questões sobre desenvolvimento e meio ambiente. Editora CeJUP, Belém. 1997.

Estrutura ou sentimento: a relação com o animal na Amazônia.

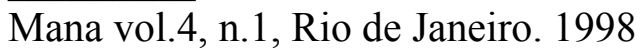


Mas allá de la naturaleza y de la cultura. IN: MARTINEZ, L. M. (ed.). Cultura y Naturaleza. Bogotá: Jardin Botánico de Bogotá José Celestino Mutis, p. 7696. 2011. 51, 2011b.

As duas naturezas de Lévi-Strauss. Sociologia \& Antropologia. v.01.02: 35-

A antropologia da natureza de Philippe Descola. Entrevista. Topoi. Revista de História, Rio de Janeiro, v. 14, no. 27, p. 492-514, jul./dez. 2013. Disponível em: $<$ www.revistatopoi.org $>$.

DUPIRE, M. "Des Goûts et des odeurs: classifications et universaux". L'Homme, tome 27, no104, p.5-25. 1987.

ELLEN, R. "Putting plants in their place: Anthropological approaches to understanding the ethnobotanical knowledge of rainforest populations". In: 'Tropical rainforest research: current issues', eds. D. S. Edwards, W.E. Booth and S.C. Choy. Kluwer: Dordrecht, 1996, pp. 457-465.

"Indigenous knowledge of the rainforest: perception, extraction and conservation". In: Maloney, B.K. (Org.). Human activities and the tropical rainforest: past, present, and possible future. Kluwer Academic Publishers, The Neetherlands. 1998.

"Palms and the prototypicality of trees: some questions concerning assumptions in the comparative study of categories and labels". In: RIVAL, L (Ed.). The social life of trees: anthropological perspectives on tree symbolism. Berg. 2001 [1998].

"Why aren't the Nuaulu like the Matsigenka? Knowledge and categorization of forest diversity on Seram, eastern Indonesia". In: Landscape ethnoecology. Concepts of biotic and physical space (Eds). Johnson, L.M. and Hunn, E.S. Berghahn Books. 2009.

ESCOBAR, A. Territories of difference: place, movements, life, redes. Duke University Press. 2008.

EWART, E. "Fazendo pessoas e fazendo roças entre os Panará do Brasil Central". Revista de Antropologia, v. 48, $\mathrm{n}^{\mathrm{o}}$ 1. 2005.

FARAGE, N. "A ética da palavra entre os Wapishana". Revista Brasileira de Ciências Sociais, Vol. 13, nº 38. 1998.

FARIA, R. B. M. Povos indígenas na Amazônia e o mercado de produtos florestais não madeireiros: no uso de recursos naturais pelos Araweté. Dissertação de mestrado. PROCAM/USP, São Paulo. 2007.

FAUSTO, C. Inimigos Fiéis: História, Guerra e Xamanismo na Amazônia. Edusp, São Paulo. 2001. 
8(2). 2002.

"Banquete de gente: comensalidade e canibalismo na Amazônia". Mana

"Donos demais: maestria e domínio na Amazônia". Mana, vol.14/2. 2008.

FIGUEIREDO, M. V. A flecha do ciúme. O parentesco e seu avesso segundo os Aweti do Alto Xingu. Tese de Doutorado, PPGAS-Museu Nacional/UFRJ, Rio de Janeiro. 2010 .

FRAZÃO-MOREIRA, A. "As classificações botânicas Nalu (Guiné-Bissau): consensos e variabilidades. Etnográfica, v. (1), p. 131-155, 2001.

GALAN DE PAULA, C. "Breve comparação entre modos de criatividade melanésios e euro-americanos seguida de sugestões de modos ameríndios de criação". Primeiros Estudos, n.1. 2011.

GALLOIS, D.T. $O$ movimento na cosmologia waiapi: criação, expansão $e$ transformação do universo. Tese de doutorado, USP, São Paulo. 1988.

Ka'a rewarã. Apina \& Iepé. 2011. p. 73-79.

GARCIA, U.F. Karawara: a caça e o mundo dos Awá-Guajá. Tese de doutorado, FFLCH/USP, São Paulo. 2010.

"Ka'á Watá, 'andar na floresta': caça e território em um grupo tupi da Amazônia". Mediações, v. 17, n. 1:172-190. 2012a.

"O funeral do caçador: caça e perigo na Amazônia". Anuário Antropológico. 2011/II. 2012b.

GOETHE, J.W. von. A metamorfose das plantas. Imprensa Nacional-Casa da Moeda. 1993.

GOLDMAN, M. "Alteridade e experiência: antropologia e teoria etnográfica". Etnográfica, v.10, nº.1, p.161-173. 2006.

GONÇALVES, M.A. "Os nomes próprios nas sociedades indígenas das terras baixas da América do Sul". BIB, Anpocs/Relume Dumará, n. 33. 1992.

O mundo inacabado: ação e criação em uma cosmologia amazônica. Etnografia Pirahã. Ed. UFRJ, Rio de Janeiro. 2001.

GOW, P. "The Perverse Child: Desire in a Native Amazonian Subsistence Economy". Man, New Series, v. 24, n. 4. 2005.

GRUBER, J.G. (Org.). O livro das árvores. Organização Geral dos Professores Ticuna Bilíngues, $2^{\text {a }}$ Ed., 1998.

GUERREIRO JÚNIOR, A.R. Ancestrais e suas sombras: uma etnografia da chefia kalapalo e seu ritual mortuário. Tese de doutorado, UNB, Brasília. 2012. 
HIRSCH, E. \& O'HANLON, M. The Anthropology of Landscape: perspectives on place and space. Claredon Press. Oxford. 2003 [1995].

HUNN, E. "The Utilitarian Factor in Folk Biological Classification", American Anthropologist, 84 (4), 830-847. 1982.

INGOLD, T. The perception of the environment. Essays in livelihood, dwelling and skill. Routledge, London. 2000.

"Jornada ao longo de um caminho de vida: mapas, descobridor-caminho e navegação". Religião e Sociedade, v. 25, nº 1, p. 76-110. 2005.

Lines: a brief history. Routledge. 2007. p. 72-84.

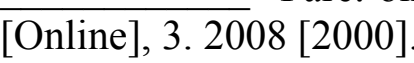
v.33, n.1. 2010

"Da transmissão de representações à educação da atenção". Educação,

"Trazendo as coisas de volta à vida: emaranhados criativos num mundo de materiais". Horizontes antropológicos, ano 18, $\mathrm{n}^{\mathrm{o}} .37 .2012$.

JARA, F. El camino del kumu: ecología e ritual entre los akuriyó de Surinam. ISOR, Utrecht. 1990.

KELLY, J.A. "Fractalidade e troca de perspectivas". Mana, vol. 7, nº. 2. 2001.

KOHN, E. O. Natural engagements and ecological aesthetics among the Ávila Runa os amazonian Ecuador. Doctoral thesis. Madison, University of Wisconsin. 2002.

"How dogs dreams. Amazonian natures and the politics of transspecies engagement". American Ethnologist, vol. 34, n 1. 2007.

KOPENAWA, D \& ALBERT, B. A queda do céu: Palavras de um xamã yanomami. Companhia das Letras, São Paulo. 2015.

LATOUR, B. Jamais fomos modernos: ensaio de antropologia simétrica. Ed.34, Rio de Janeiro. 1994 [1991]

Reensamblar lo Social: una introducción a la teoria del actor-red. Buenos Aires: Manantial, 2008 [2005].

LÉVI-STRAUSS, C. "Os cogumelos na cultura". In: Antropologia Estrutural Dois. Tempo Brasileiro. 1976 [1973]. A oleira ciumenta. Ed. Brasiliense. 1986 [1985]. 
"Estruturalismo e ecologia". O olhar distanciado. Edições 70. 1986

[1983].

"O uso das plantas silvestres da américa do sul tropical". In: Ribeiro, B. G. (Coord).. Suma etnológica brasileira. Etnobiologia. Volume 1. Ed. Vozes, Petrópolis. $2^{\mathrm{a}}$ ed. 1987.

[1971].

O cru e o cozido (Mitológicas v.1). Ed. Brasiliense, São Paulo. 1991

O pensamento selvagem. Papirus, Campinas, $5^{\text {a }}$ ed. 2005 [1962].

Do mel às cinzas (Mitológicas v.2). Cosac Naify, São Paulo. 2004

[1967].

Paulo. 2008 [1958].

"A eficácia simbólica". Antropologia estrutural. Cosac Naify, São O homem nu (Mitológicas v.4). Cosac Naify, São Paulo. 2011 [1971].

LIMA, T. S. "O dois e seu múltiplo. reflexões sobre o perspectivismo em uma cosmologia tupi”. Mana, 2 (2), p. 21-47. 1996.

"O que é um corpo?". Religião e Sociedade, v. 22, n.1, p. 9-20. 2002.

Um peixe olhou pra mim: o povo Yudjã e a perspectiva. Ed. UNESP: ISA, São Paulo e NuTI, Rio de Janeiro. 2005.

MACEDO, V. "Jepota entre os Guarani. Estar outro e querer o outro". 35 Encontro Anual da Anpocs, v.1. 2011.

MAIZZA, F. Cosmografia de um mundo perigoso: espaço e relações de afinidade entre os Jarawara da Amazônia. Tese de doutorado, FFLCH/USP, São Paulo. 2009.

"Entre almas e patrões: reflexões acerca da alteridade jarawara". In: Amoroso, M; Mendes dos Santos, G. (Orgs.). Paisagens amerindias: lugares, circuitos e modos de vida na amazônia. Terceiro Nome, São Paulo. 2013.

Mana 20 (3). 2014.

"Sobre as crianças-planta: o cuidar e o seduzir no parentesco jarawara".

MCCALLUM, C. "Morte e pessoa entre os Kaxinawá". Mana 2(2). 1996.

"Alteridade e sociabilidade Kaxinauá: perspectivas de uma antropologia da vida diária". Revista Brasileira de Ciências Sociais, vol. 13, nº 38. 1998.

MENDES DOS SANTOS, G. Da cultura à natureza: um estudo do cosmos e da ecologia dos Enawene-Nawe. Tese de doutorado, FFLCH/USP, São Paulo. 2006. 
MÉTRAUX, A. “Armas”. In: Ribeiro, B. G. (Coord.). Suma etnológica brasileira. Teconologia indígena. Volume 2. Vozes; FINEP, Petrópolis, 2a ed. 1987.

NUNES, A. "No tempo e no espaço: brincadeiras das criança A'uwe-Xavante. In: Lopes da Silva, A; Macedo, A.V.L.daS.; Nunes, A. (Orgs.). Crianças indígenas: ensaios antropológicos. Global, São Paulo. 2002.

OVERING, J. "A estética da produção: o senso de comunidade entre os Cubeo e os Piaroa" Revista de Antropologia, Vol.34. 1991.

"Elogio do cotidiano: a confiança e a arte da vida social em uma comunidade amazônica". Mana 5(1). 1999.

"O fétido odor da morte e os aromas da vida. Poética dos saberes e processo sensorial entre os Piaroa da Bacia do Orinoco". Revista de Antropologia, v. 49, $\mathrm{n}^{\mathrm{o}} 1.2006$.

PARDINI, P. "Natureza e Cultura na paisagem amazônica - uma experiência fotográfica com ressonâncias no pensamento ameríndio e na ecologia histórica". Boletim do Museu Paraense Emílio Goeldi, vol.7, nº.2, p. 203-229. 2012.

PLATÃO. Diálogos. Teeteto Crátilo. 3. UFPA, Belém. 2001.

POSEY, D. A. "Manejo da floresta secundária, capoeiras, campos e cerrados". In: Ribeiro, B. G. (Coord).. Suma etnológica brasileira I - Etnobiologia. Ed. Vozes, Petrópolis. 1987. $2^{\mathrm{a}} \mathrm{ed}$.

POSTIGO, A.de A. A terra vista do alto: usos e percepções acerca do espaço entre os moradores do Rio Bagé, Acre. Tese de doutorado, IFCH/UNICAMP, Campinas. 2010.

REICHEL-DOLMATOFF, G. "Cosmology as ecological analysis: a view from the forest", Man, 11:307-318. 1976.

"Cosmologia como análisis ecológico: una perspectiva desde la selva pluvial". In: Chamanes de la selva pluvial: ensayos sobre los indios Tukano del Noroeste Amazónico. Themis Books. Londres. 1977.

RIVAL, L. "The Growth of Family Trees: Understanding Huaorani Perceptions of the Forest”. Man, New Series, v. 28, nº. 4, p. 635-652, 1993.

RIVAL, L (Ed).. The social life of trees: anthropological perspectives on tree symbolism. Berg. 2001 [1998].

ROSENGREN, D. "Corporeidade matsingenka: uma realidade não biológica. Sobre noções de consciência e a constituição de identidades. Revista de Antropologia, vol. 49/1. 2006.

SANTOS-GRANERO, F. "Writing history into the landscape: space, myth and ritual in contemporary Amazonia". American Ethnologist, v. 25, nº. 2, p. 128-148. 1998. 
"Vitalidades sensuais. Modos não corpóreos de sentir e conhecer na Amazônia indígena". Revista de Antropologia, vol.49/1. 2006.

SEEGER, A., DAMATTA, R. \& VIVEIROS DE CASTRO, E. "A construção da pessoa nas sociedades indígenas brasileiras". In: João Pacheco de Oliveira Filho (Org.), Sociedades indígenas e indigenismo no Brasil. Rio de Janeiro: Marco Zero. 1987.

SIGRIST, T. Aves da Amazônia Brasileira. Avis Brasilis, São Paulo. 2008.

SOARES-PINTO, N. "Sobre alguns modos de usar a cultura dos Outros". In: Carneiro da Cunha, M. \& Cesarino, P. de N. (Orgs.). Políticas culturais e povos indígenas. Cultura Acadêmica Ed, São Paulo. 2014.

SOLANO, E. de J.B. Descrição gramatical da língua Araweté. Tese de doutorado, LALI/UnB, Brasília. 2009.

STRATHERN, M. Partial Connections. Updated Edition. Oxford: Altamira Press. 2004 [1991].

Nome, São Paulo. 2013.

Fora de contexto: as ficções persuasivas da antropologia. Terceiro

"Sem natureza, sem cultura: o caso Hagen". In: O efeito etnográfico e outros ensaios. Cosac Naify, São Paulo. 2014a.

"O conceito de sociedade está teoricamente obsoleto?". In: O efeito etnográfico e outros ensaios. Cosac Naify, São Paulo. 2014b.

SZTUTMAN, R. "O espírito na América". Novos estudos - CEBRAP, nº.72. 2005.

"Ética e profética nas mitológicas de Lévi-Strauss". Horizontes Antropológicos, ano 15, n. 31, p. 293-319. 2009.

TAYLOR, A.C. "O corpo da alma e seus estados: uma perspectiva amazônica sobre a natureza de ser-se humano". Cadernos de Campo, n.21. 2012.

TESTA, A. Q. Caminhos de saberes guarani mbya: modos de criar, crescer e comunicar. Tese de doutorado, FFLCH/USP, São Paulo. 2014.

VANDER VELDEN, F. F. Por onde o sangue circula: os Karitiana e a intervenção biomédica. Dissertação de Mestrado. IFCH-Unicamp. 2004.

Karitiana". Habitus, v.5, n.2. 2007.

"Circuitos de sangue: corpo, pessoa e sociabilidade entre os "O gosto dos outros: o sal e a transformação dos corpos entre os Karitiana no sudoeste da Amazônia” In: Temáticas. Dossiê Estudos Indígenas, IFCH/UNICAMP. 2008. 
VELHO, O. "De Bateson a Ingold: passos na constituição de um paradigma ecológico". Mana 7(2):133-140. 2001.

VIDAL, W.N.; VIDAL, M.R.R. Botânica - organografia: quadros sinóticos ilustrados de fanerógamos. Ed. UFV, $4^{\mathrm{a}}$ ed. 2003.

VIVEIROS DE CASTRO, E. Araweté: Os Deuses Canibais. Jorge Zahar/Anpocs. 1986.

"A fabricação do corpo na sociedade xinguana". In: João Pacheco de Oliveira Filho (org)., Sociedades indígenas e indigenismo no Brasil. Rio de Janeiro: Marco Zero. 1987.

"Alguns aspectos da afinidade no dravidianato amazônico", In: M. Carneiro da Cunha \& E. Viveiros de Castro (Orgs.). Amazônia: etnologia e história Indígena. NHII-USP/ FAPESP, São Paulo. 1993.

"Os pronomes cosmológicos e o perspectivismo ameríndio". Mana - Estudos de Antropologia Social. Rio de Janeiro, Museu Nacional/UFRJ, v. 2, p. 115-144. 1996.

"Atualização e contra-efetuação do virtual na socialidade amazônica: o processo de parentesco". Ilha, nº 1. 2000.

"O nativo relativo". Mana. Vol.8/1, p.113-148. 2002a.

"Perspectivismo e naturalismo na Amazônia indígena". In: A inconstância da alma selvagem. Cosac \& Naify, São Paulo. 2002 b.

"O problema da afinidade na Amazônia". In: $A$ inconstância da alma selvagem. Cosac \& Naify, São Paulo. 2002c.

"O conceito de sociedade em antropologia". In: $A$ inconstância da alma selvagem. Cosac \& Naify, São Paulo. 2002d.

"Esboço de cosmologia Yawalapití". In: A inconstância da alma selvagem. Cosac \& Naify, São Paulo. 2002e.

"A floresta de cristal: notas sobre a ontologia dos espíritos amazônicos". Cadernos de Campo. v.15, n. 14/15. 2006.

"Transformação" na antropologia, transformação da"antropologia"". Mana 18(1): 151-171. 2012.

WAGNER, R. "Existem grupos sociais nas terras altas da Nova Guiné?". Cadernos de Campo, n. 19, p. 237-257, tradução de Iracema Dulley. 2010.

A invenção da cultura. Cosac Naify, São Paulo. 2010a.

"Pessoa fractal", Ponto Urbe, vol. 8 [http://www.pontourbe.net/edicao8- 
traducoes/168-a-pessoa-fractal], tradução de Iracema Dulley e Christiano Tambascia. 2011 [1991].

YANO, A.M.T. A fisiologia do pensar: corpo e saber entre os Caxinauá. Dissertação de mestrado, FFLCH/USP, São Paulo. 2010.

Carne e tristeza: sobre a culinária caxinauá e seus modos de conhecer. Tese de doutorado, FFLCH/USP, São Paulo. 2014. 